\title{
Avaliação da Resistência de Microrganismos Patogênicos \\ à Desinfecção Sequencial com Ozônio-Radiação \\ Ultravioleta e Cloro-Radiação ultravioleta
}

Juliana Lourenção

Dissertação apresentada à Escola de Engenharia de São Carlos da Universidade de São Paulo, como parte dos requisitos para obtenção do título de Mestre em Engenharia Hidráulica e Saneamento.

ORIENTADOR: Luiz Antonio Daniel

São Carlos 
AUTORIZO A REPRODUÇÃO E DIVULGAÇÃO TOTAL OU PARCIAL DESTE TRABALHO, POR QUALQUER MEIO CONVENCIONAL OU ELETRÔNICO, PARA FINS DE ESTUDO E PESQUISA, DESDE QUE CITADA A FONTE.

Ficha catalográfica preparada pela Seção de Tratamento da Informação do Serviço de Biblioteca - EESC/USP

\begin{tabular}{|c|c|}
\hline \multirow[t]{3}{*}{ L892a } & $\begin{array}{l}\text { Lourenção, Juliana } \\
\text { Avaliação da resistência de microrganismos patogênicos } \\
\text { à desinfeção seqüencial com ozônio-radiação ultravioleta } \\
\text { e cloro-radiação ultravioleta / Juliana Lourenção; } \\
\text { orientador Luiz Antonio Daniel. -- São Carlos, } 2009 \text {. }\end{array}$ \\
\hline & $\begin{array}{l}\text { Dissertação (Mestrado-Programa de Pós-Graduação e Área } \\
\text { de Concentração em Hidráulica e Saneamento) -- Escola de } \\
\text { Engenharia de São Carlos da Universidade de São Paulo, } \\
2009 \text {. }\end{array}$ \\
\hline & $\begin{array}{l}\text { 1. Desinfecção seqüencial. 2. Desinfecção de águas } \\
\text { residuárias. 3. Esgotos sanitários. 4. Cloro. 5. Ozônio. } \\
\text { 6. Radiação ultravioleta. 7. Escherichia coli. } \\
\text { 8. Coliformes totais. 9. Clostridium perfringens. } \\
\text { I. Título. }\end{array}$ \\
\hline
\end{tabular}


FOLHA DE JULGAMENTO

Candidata: Bacharel JULIANA LOURENÇÃO

Dissertação defendida e julgada em 05/06/2009 perante a Comissão Julgadora:

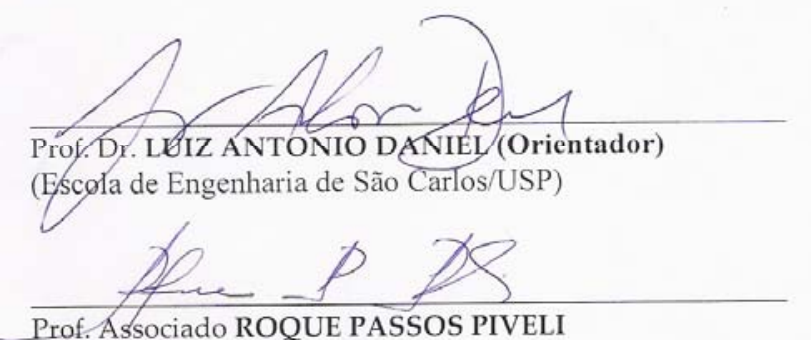

APROUDDA (Escola Politécnica/USP)

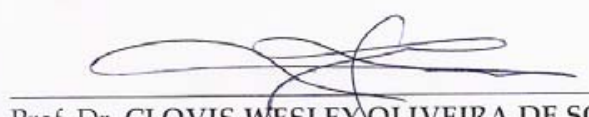

Aprownt

Prof. Dr. CLOVIS WESLEY OLIVEIRA DE SOUZA

APROVTRE (Universidade Federal de-São)Carlos/USP)

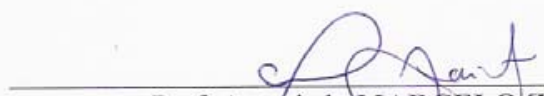

Prof. Associado MARCELO ZAIAT Coordenador do Progranka de Pós-Graduação em Engenharia (Hidráulica e Saneamento)

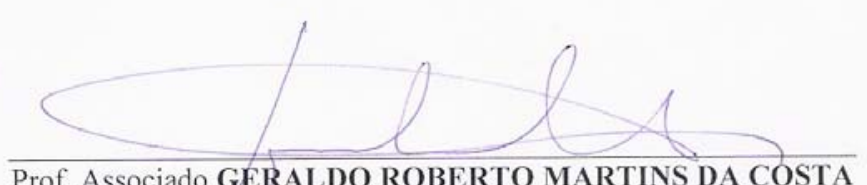

Prof. Associado GERALDO ROBERTO MARTINS DA COSTA Presidente da Comissão da Pós-Graduação da EESC 

Dedico este trabalho aos meus pais, Nadir e César, por todo amor doado e por sempre apoiarem e incentivarem o meu crescimento acadêmico, e aos meus futuros e já queridos filhos. 


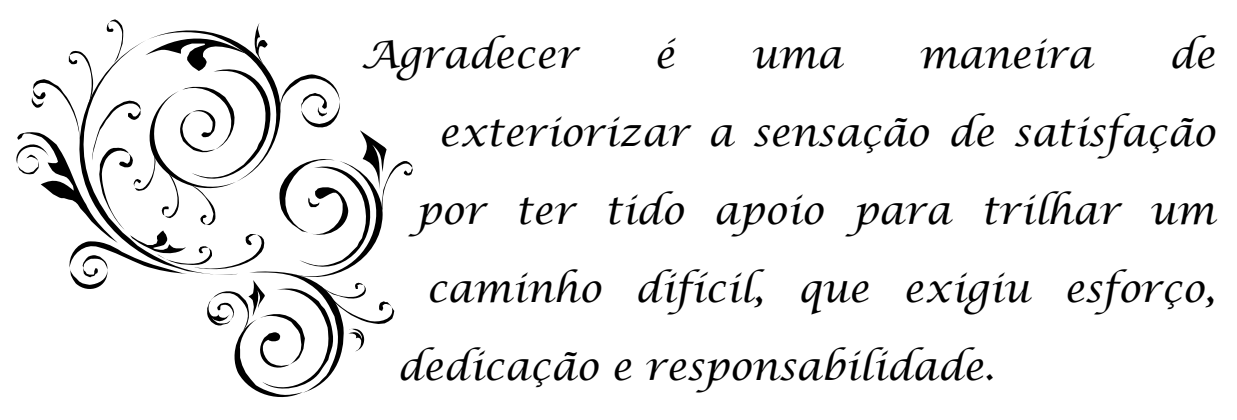

$\mathcal{N} a ̃ o$ vivemos sozinhos, precísamos uns dos outros, e posso garantir que uma construção por mais simples e pequena que seja, quando realizada em conjunto, com auxilio técnico e emocional, o objeto construído tem mais valor, tem vida, tem consistência.

O resultado dessa construção permitiu semear uma sementinha rica em vontade de projetar construções maiores.

\section{$\mathcal{A G R A D E C ̧ O :}$}

A Deus e seus mensageiros por sempre iluminarem e orientarem a minha vida.

Ao Prof. Dr. Luiz Antonio Daniel pela reconhecida orientação prestada para a realização deste trabalho, professor que eu tenho muito respeito e admiração.

Aos professores Silvia Cláudia Povinelli, Clovis Wesley Oliveira de Souza, Marcelo Zaiat, Jurandyr Povinelli, Roque Passos Piveli pelas sugestões para melhorar a dissertação da qualificação até a defesa e pela disponibilidade por participar das bancas realizadas para a construção dessa dissertação.

À Escola de Engenharia de São Carlos, em especial ao Departamento de Engenharia Hidráulica e Saneamento pela oportunidade de realização do curso de mestrado e por disponibilizar-me área experimental e suporte laboratorial.

Ao Conselho Nacional de Desenvolvimento Científico e Tecnológico pela concessão da bolsa de mestrado.

À Fundação de Amparo à Pesquisa do Estado de São Paulo pelo apoio financeiro para a realização desta pesquisa (processo 07/08499-3).

Ao Alcino pela ajuda tão prestimosa na manutenção dos equipamentos usados. 
Aos amigos e "professores" que me ajudaram a superar as minhas dificuldades conceituais: Rafael Ceribelli, Renata Barreira, Théo Syrto, Ricardo Oliveira, Ana Flávia Pontes, André Pioltine, Bruna Moraes, Aline Tavares e Camila Tolledo.

À Natalia Fischer, Jaqueline Almeida, Gabriel Sacchi, Gustavo Silva, Glaucio de Souza, Raphael Medeiros e Renata Pereira pela companhia e cooperação prestadas durante a fase laboratorial.

À Glauce Guimarães por todo suporte técnico laboratorial prestado.

Aos laboratoristas do laboratório de saneamento: Júlio Trofino, Paulo Fragiácomo e Juliana.

À Rosemeire Aparecida de Jesus (Rose) e Maria Auxiliadora de C. Altieri Pin (Sá) por toda atenção prestada.

Aos funcionários e professores do Departamento de Engenharia Hidráulica e Saneamento da USP- São Carlos- pela seriedade, profissionalismo, respeito e por terem me fornecido a oportunidade de me dedicar e aprender um pouco sobre saneamento.

Aos funcionários e professores do Instituto Oceanográfico da USP - São Paulo- que conquistaram a minha amizade, incentivaram esta pesquisa e me ajudaram a valorizar este trabalho em especial Luz Amélia Vega Pérez e Maysa Pompeu.

Agradeço também ao Moysés Gonsalez Tessler, Márcia Caruso Bícego, Aparecida Antunes da Silva (Cidinha), José Aparecido Teixeira (Cido), Raimunda de Almeida Santos (Ray), Maria de Jesus Pureza, Claudinha Pires, Evaldo de Almeida Pessoa, Laura do Rosário Marcolino, André Blumer Bezerra que sempre me acolheram, me ouviram e acompanharam o meu crescimento.

Às minhas amigas que estiveram presentes em pensamento durante toda a realização desta dissertação: Lilian Amado Marconato, Louise Franco de Oliveira, Ana Cecília Albergaria Rizzatti, Darien Danielle Mizuta e, em memória, Karina Bisaio.

Aos meus pais Cesar e Nadir, aos meus irmãos Giovana e Gil por tentarem ter paciência comigo.

Ao Fernando Matias pelo carinho e amor doados, compartilhados e tão necessários para a manutenção do meu equilíbrio emocional.

Desculpo-me por não colocar o nome de todos que se preocuparam e se importaram comigo durante o mestrado, tenho por todas as pessoas que passaram comigo por esta fase toda a minha admiração. 


\section{Sumário}

Lista de Figuras ............................................................................................................... V

Lista de Tabelas ..............................................................................................iii

Lista de Abreviaturas e Siglas.........................................................................xi

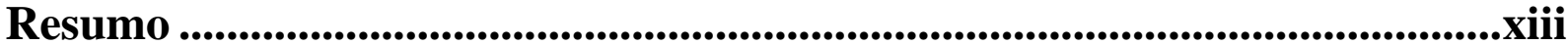

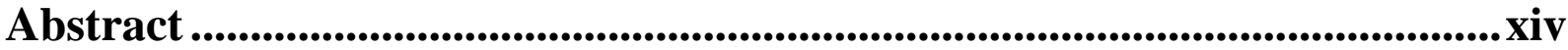

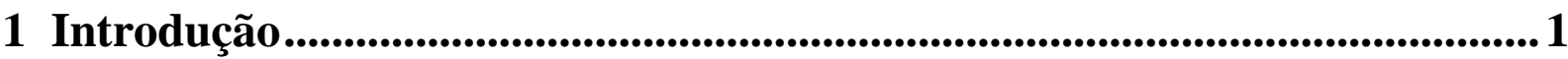

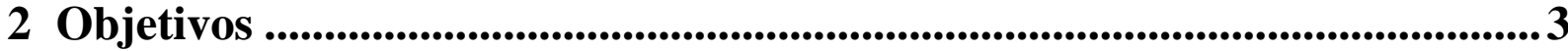

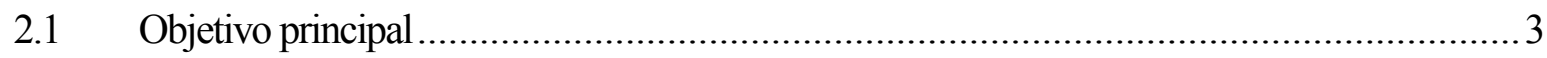

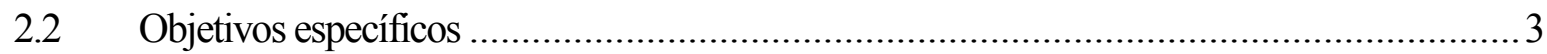

3 Revisão Bibliográfica ................................................................................................4

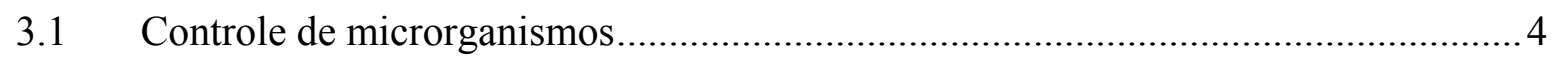

3.1.1 Condições que influenciam a ação antimicrobiana ...............................................

3.2 Doenças - relacionadas à poluição fecal...………………………………………....

3.3 Microrganismos Indicadores de poluição fecal ...........................................................

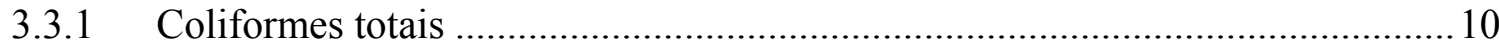

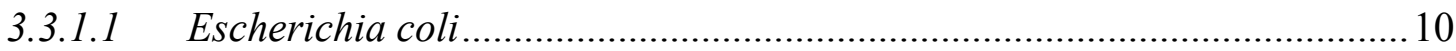

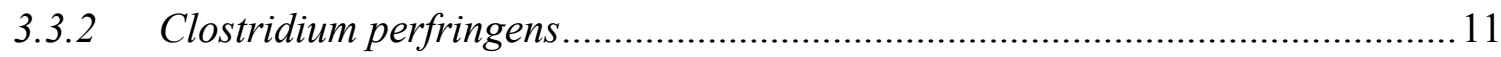

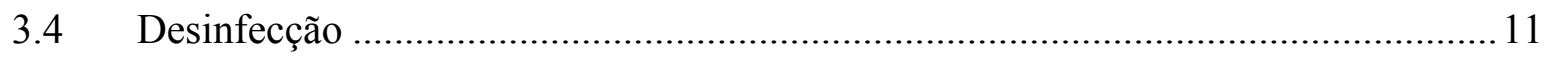

3.4.1 Características desejáveis para um desinfetante ..................................................13

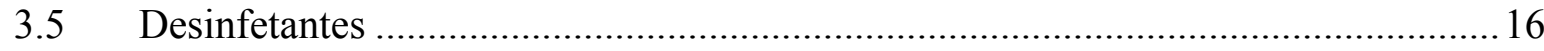

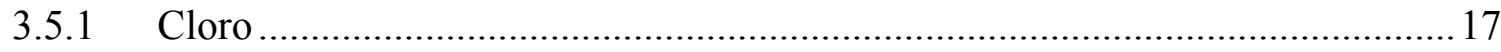

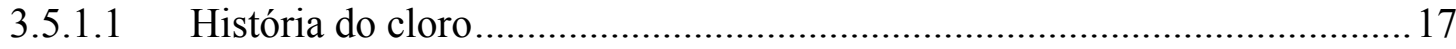

3.5.1.2 Aplicação do cloro no tratamento de efluentes ........................................... 18

3.5.1.3 Mecanismos de desinfecção com cloro …………………………………......22

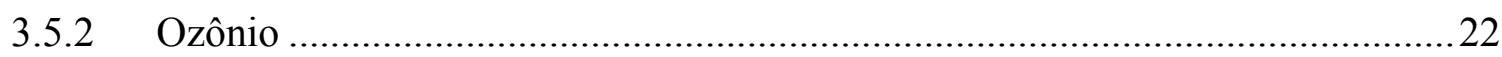

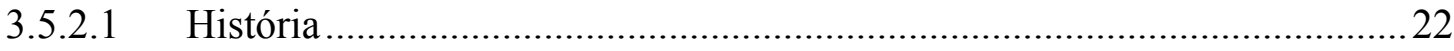

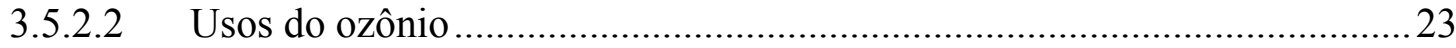




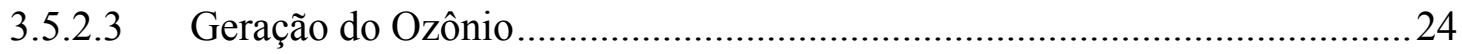

3.5.2.4 Mecanismos de Decomposição do Ozônio ..................................................2.

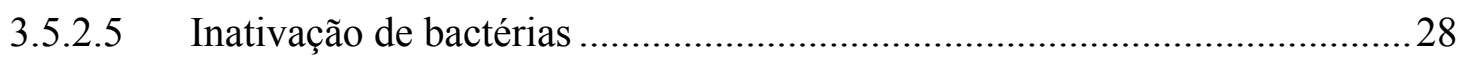

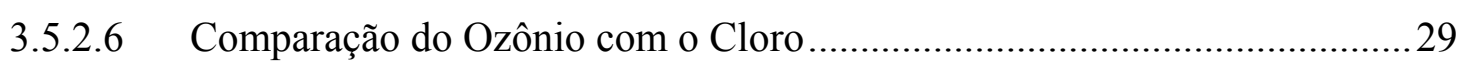

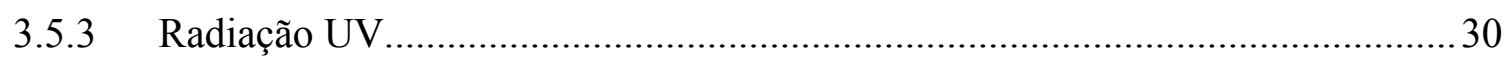

3.5.3.1 Mecanismos de desinfecção com radiação UV ........................................... 31

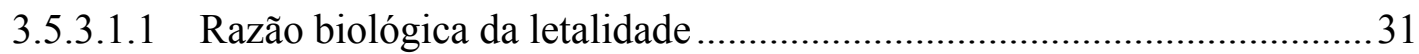

3.5.3.2 Recuperação de microrganismos irradiados por radiação UV ..................... 32

3.5.3.3 Fatores interferentes na eficácia da desinfecção com UV ...........................33

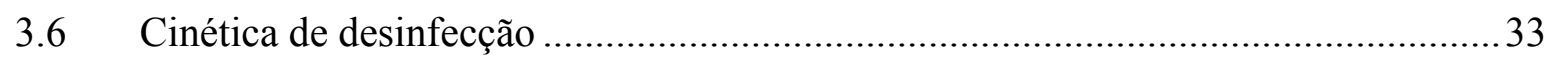

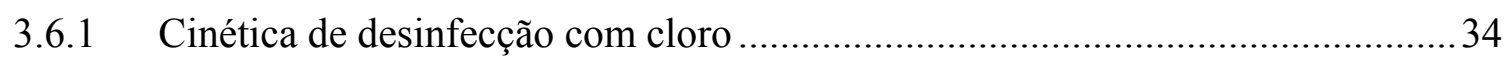

3.6.2 Cinética de desinfecção com radiação UV …….................................................. 37

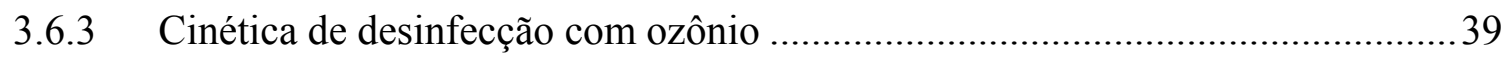

4 Material e Métodos .........................................................................41

4.1 Ensaios de desinfecção com cloro seguido de radiação UV ..................................41

4.1.1 Fase I - Ensaios de desinfecção com cloro ................................................... 41

4.1.2 Fase II - Ensaios de desinfecção com radiação ultravioleta ................................ 43

4.2 Ensaio de desinfecção com ozônio seguido de radiação UV ..................................45

4.2.1 Fase I - Ensaios de desinfecção com ozônio...................................................... 46

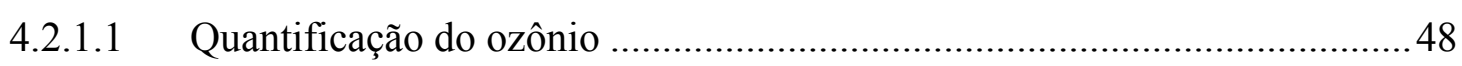

4.2.1.2 Calibração do Gerador de Ozônio.............................................................49

4.2.1.3 Balanço de massa do ozônio dissolvido na fase líquida .............................51

4.2.2 Fase II - Ensaios de desinfecção com radiação UV ............................................54

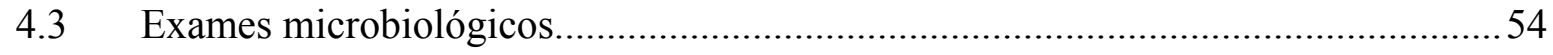

4.3.1 Exames para determinação de Clostridium perfringens .....................................54

4.3.1.1 Preparação da água de diluição ...............................................................56

4.3.1.2 Preparação dos meios de cultura para Clostridium perfringens...................56

4.3.1.2.1 Meio diferencial enriquecido para Clostrídios (DRCM) ........................56

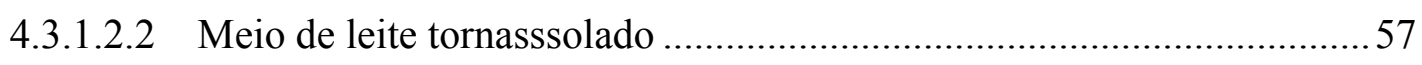

4.3.1.3 Preparação de Soluções de citrato férrico amoniacal verde a 7\% e sulfito de sódio $4 \% 57$

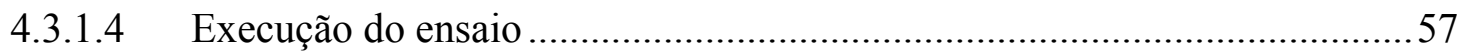

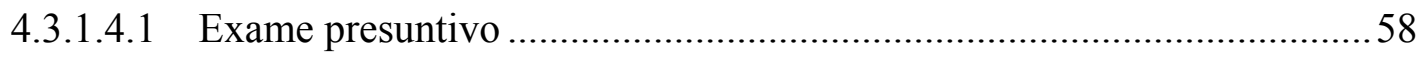




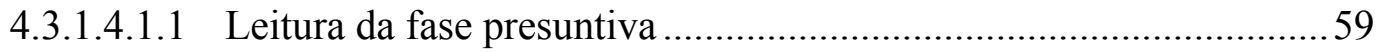

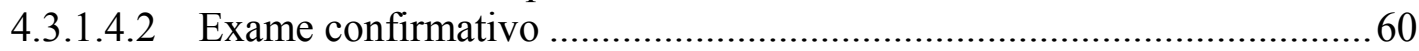

4.3.1.4.2.1 Leitura da fase confirmativa ......................................................60 60

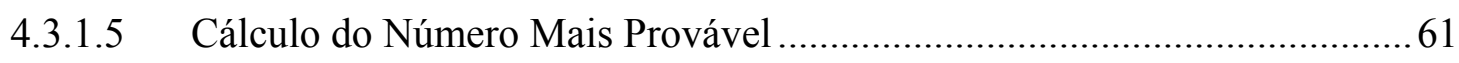

4.3.2 Exames para determinação de coliformes totais e Escherichia coli....................63

4.3.2.1 Preparação do meio de cultura Chromocult ${ }^{\circledR}$.............................................63

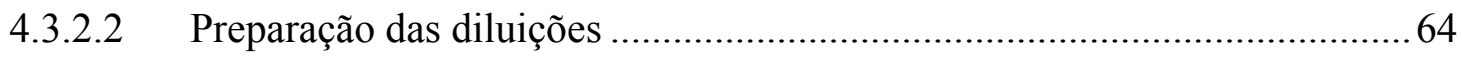

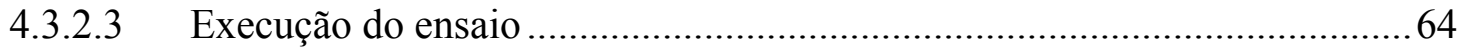

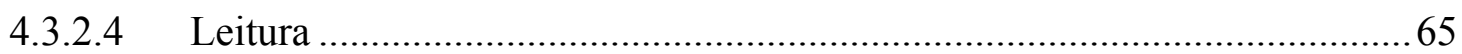

5 Resultados e Discussão................................................................................ 68

5.1 Ensaios de desinfecção com cloro seguido de radiação ultravioleta .........................68

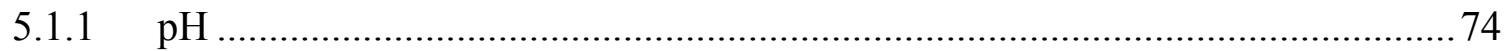

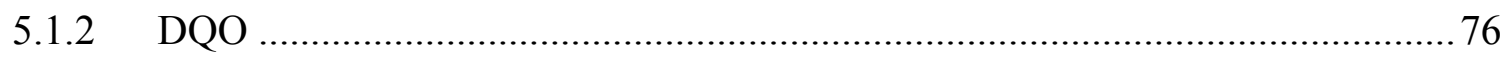

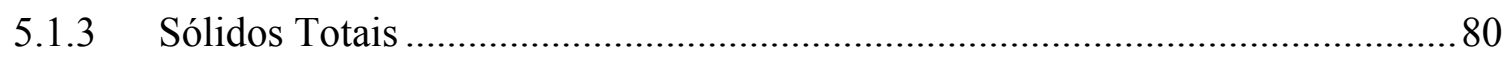

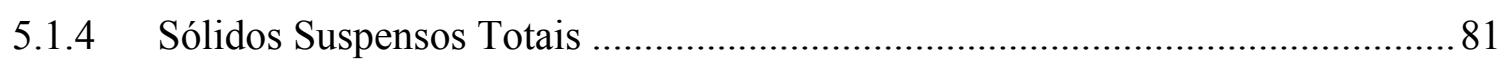

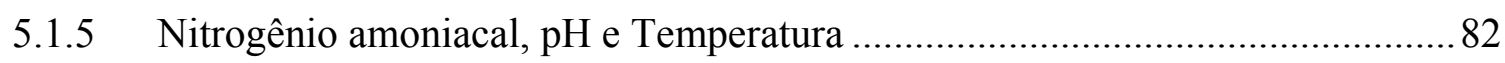

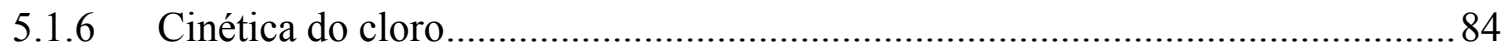

5.1.6.1 Inativação de $C$. perfringens e coliformes totais na desinfecção somente com cloro 84

5.1.6.2 Inativação de C. perfringens e coliformes totais na desinfecção sequencial de cloro seguido de UV

5.1.6.3 Variação da Inativação dos microrganismos em relação ao tempo de

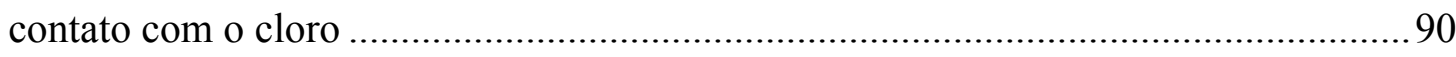

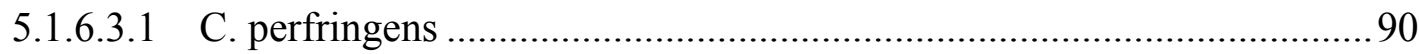

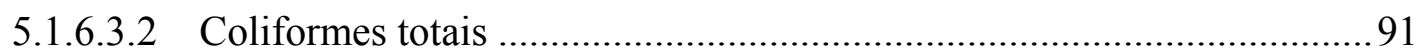

5.1.6.4 Relação entre inativação de microrganismos indicadores e SST ................ 92

5.2 Calibração do gerador de ozônio ........................................................................ 94

5.3 Balanço de massa obtido nos ensaios com ozônio ................................................. 97

5.4 Ensaios de desinfecção com ozônio seguido de radiação ultravioleta .....................98

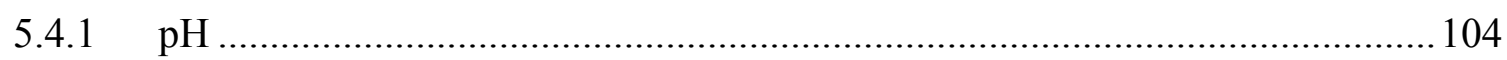

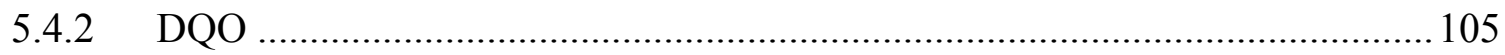

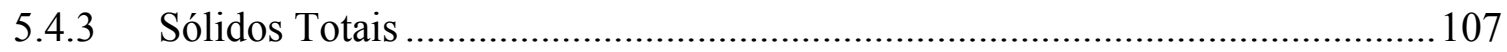

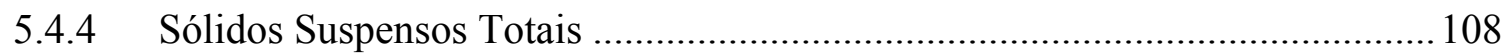

5.4.5 Cinética de desinfecção com ozônio ............................................................... 109 
5.4.5.1 Inativação de C. perfringens, coliformes totais e E. coli na desinfecção somente com ozônio

5.4.5.2 Inativação de C. perfringens, coliformes totais e E. coli na desinfecção sequencial 111

5.4.5.3 Influência do tempo de contato com ozônio na inativação de C. perfringens, coliformes totais e E. coli.

5.4.5.4 Influência dos sólidos suspensos totais na inativação dos microrganismos indicadores

5.5 Discussão dos resultados comparando os efeitos do cloro e do ozônio sobre o efluente do reator UASB

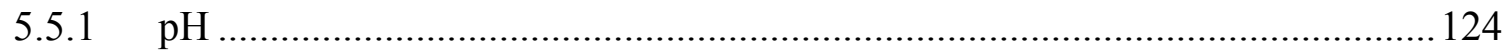

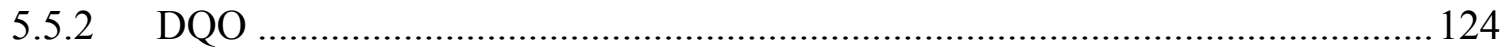

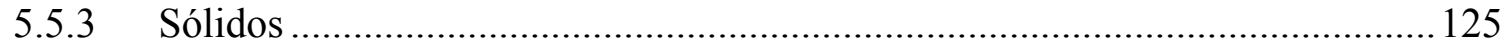

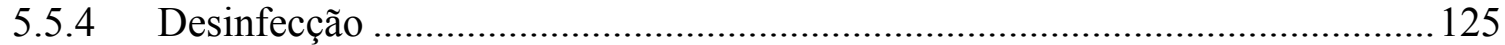

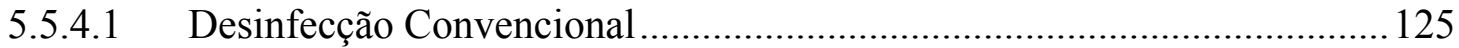

5.5.4.2 Desinfecção sequencial ....................................................................... 126

5.6 Limitações para a quantificação de coliformes totais e E. coli .............................. 127

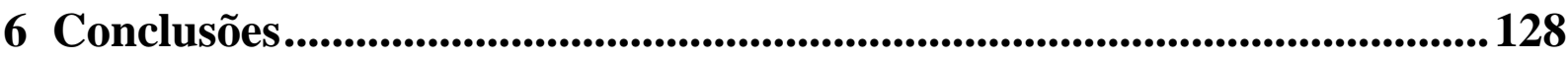

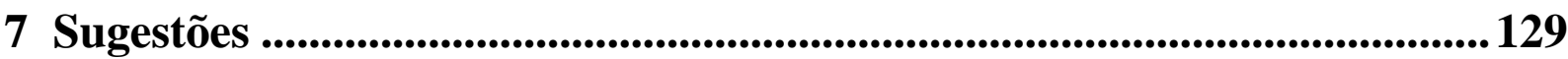

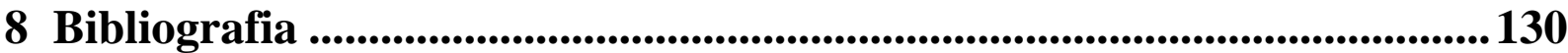

9 Apêndice A ........................................................................................... 136

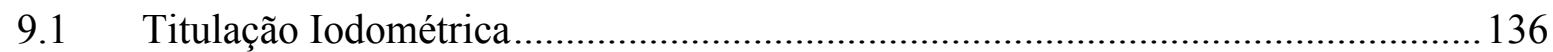




\section{Lista de Figuras}

Figura 3.1: Distribuição do ácido hipocloroso e do íon hipoclorito em água, em diferentes valores de $\mathrm{pH}$ e temperatura.

Figura 3.2: Lei de Chick e desvios. 36

Figura 4.1: Ilustração do reator usado na desinfecção com radiação UV. 43

Figura 4.2: Localização dos pontos de medição da radiação UV no reator 44

Figura 4.3: Esquema da unidade piloto utilizada nos ensaios de ozonização. 46

Figura 4.4: Representação do volume de controle para obtenção do balanço de ozônio (linha tracejada). .52

Figura 4.5: Figura ilustrativa dos tubos de DRCM 59

Figura 4.6: Tubos positivos e negativos de C. perfringens 60

Figura 4.7: Representação do crescimento de colônias no meio Chromocult Coliform Agar®

Figura 5.1- Variação do pH com a aplicação de cloro. .74

Figura 5.2- Variação do pH com a aplicação de cloro 75

Figura 5.3: Variação da DQO no efluente bruto e no efluente clorado nos ensaios de desinfecção com cloro.

Figura 5.4: Interferência do cloreto na determinação da DQO da amostra clorada. .78

Figura 5.5: Valores de DQO do efluente do reator UASB para diferentes concentrações de

Sulfato de mercúrio. 78

Figura 5.6: Valores de DQO para a amostra desinfetada com cloro em diferentes concentrações de sulfato de mercúrio. .79

Figura 5.7: Variação dos Sólidos Totais nos ensaios de cloro/UV 80

Figura 5.8: Variação dos Sólidos Suspensos Totais nos ensaios de cloro/UV.

Figura 5.9: Variação do Nitrogênio amoniacal para a amostra de efluente bruto (EB) e do efluente clorado (EC).

Figura 5.10: Inativação do C. perfringens e c. totais na desinfecção com cloro para os modelos de Hom e Watson respectivamente.

Figura 5.11: Inativação de C. perfringens, E. coli e coliformes totais para os ensaios de desinfecção sequencial - cloro seguido de UV (I-A), e para a desinfecção apenas com UV ...86 Figura 5.12: Inativação de $C$. perfringens e coliformes totais nos ensaios II e III.

Figura 5.13: Inativação de $C$. perfringens e coliformes totais nos ensaios IV, V e VI............88

Figura 5.14: Inativação de C. perfringens e coliformes totais nos ensaios VII e VIII. 
Figura 5.15: Influência do tempo de contato do cloro na inativação de C. perfringens na desinfecção sequencial com cloro seguido de radiação UV.

Figura 5.16: Influência do tempo de contato do cloro na inativação de coliformes totais na desinfecção sequencial com cloro seguido de radiação UV.

Figura 5.17: Relação entre SST e a remoção de $C$. perfringens para as doses de UV estudadas.

Figura 5.18: Relação entre SST e a remoção de coliformes totais para as doses de UV estudadas

Figura 5.19: Curvas de calibração para a relação entre a produção de ozônio ( $\mathrm{g} \mathrm{O}_{3} / \mathrm{h}$ ) e a vazão de gás $(\mathrm{L} / \mathrm{h})$. 96

Figura 5.20: Variação do pH para os ensaios de ozonização. ............................................... 104

Figura 5.21: Variação da DQO nos ensaios de desinfecção com ozônio................................ 105

Figura 5.22: Relação entre a massa de DQO removida (DQOr) e a massa de ozônio consumido. 106

Figura 5.23: Variação dos Sólidos Totais nos ensaios de ozonização.

Figura 5.24: Variação dos Sólidos Suspensos Totais nos ensaios de ozônio/UV.

Figura 5.25: Inativação de $C$. perfringens na desinfecção somente com ozônio................... 110

Figura 5.26: Inativação de coliformes totais na desinfecção com ozônio somente................. 110

Figura 5.27: Inativação de E. coli na desinfecção somente com ozônio.

Figura 5.28: Inativação de C. perfringens, coliformes totais e E. coli no ensaio de desinfecção sequencial de ozônio seguido de UV (0-A) e somente UV (0-B).

Figura 5.29: Inativação de $C$. perfringens, coliformes totais e $E$. coli na desinfecção sequencial de ozônio seguido de UV para a dose os experimentos I, II, III-A e III-B, para a dose de $5,6 \mathrm{mgO}_{3} / \mathrm{L}$.

Figura 5.30: Inativação de $C$. perfringens, coliformes totais e E. coli para desinfecção sequencial de ozônio seguido de radiação UV para os ensaios IV, V-A; V-B e VI

Figura 5.31: Inativação de $C$. perfringens, coliformes totais e E. coli nos ensaios de desinfecção sequencial de ozônio seguido de UV para os experimentos VII, VIII e IX.

Figura 5.32: Influência do tempo de contato do ozônio na inativação do C. perfringens para desinfecção sequencial de ozônio seguido de UV.

Figura 5.33: Influência do tempo de contato com ozônio na inativação de coliformes totais na desinfecção sequencial de ozônio seguido de UV.

Figura 5.34: Influência do tempo de contato do ozônio na inativação de E. coli na desinfecção sequencial de ozônio seguido de UV. 
Figura 5.35: Inativação de $C$. perfringens relacionando SST para doses de UV estudadas. 123 Figura 5.36: Inativação de coliformes totais relacionando SST para doses de UV estudadas.

Figura 5.37: Inativação de E. coli relacionando SST para doses de UV estudadas. 124

Figura 5.38: Membrana com colônias de coliformes totais envolvidas por sólidos 127 


\section{Lista de Tabelas}

Tabela 3.1: Doenças potencialmente relacionadas à água contaminada

Tabela 3.2: Principais microrganismos que têm sido propostos para serem usados como indicadores.

Tabela 3.3: Algumas características dos desinfetantes usados no presente trabalho

Tabela 3.4: Compostos orgânicos e seus produtos quando clorados (WATER, 2007)............20

Tabela 3.5: Algumas propriedades do ozônio........................................................................ 23

Tabela 3.6: Iniciadores, promotores e inibidores do ozônio....................................................27

Tabela 3.7: Reação do ozônio com compostos orgânicos.......................................................28

Tabela 4.1: Configuração dos experimentos de desinfecção com cloro seguido de UV..........42

Tabela 4.2: Configuração dos experimentos de desinfecção com ozônio seguido de UV.......48

Tabela 4.3: Valores de ozônio consumido e tempo de contato para se determinar CT............54

Tabela 4.4: Composição do meio diferencial enriquecido para Clostridium ..........................56

Tabela 4.5: NMP e limites de confiança de 95\% para várias combinações de resultados positivos, quando são utilizado cinco tubos por diluição e inóculos de $10 \mathrm{~mL}, 1 \mathrm{~mL}$ e $0,1 \mathrm{~mL}$ (APHA, 1998).

Tabela 4.6: Métodos analíticos, exames, análises e equipamentos empregados nos ensaios de desinfecção.

Tabela 4.7: Equações de cinética de inativação de microrganismos exploradas no presente trabalho:

Tabela 5.1: Alguns parâmetros de caracterização do esgoto bruto ao reator UASB e efluente a esse reator (PASSIG, 2005).

Tabela 5.2: Características físico-químicas e microbiológicas do esgoto no experimento I....69

Tabela 5.3: Características físico-químicas e microbiológicas do esgoto no experimento II. . 70

Tabela 5.4: Características físico-químicas e microbiológicas do esgoto no experimento III. 70

Tabela 5.5: Características físico-químicas e microbiológicas do esgoto no experimento IV.71

Tabela 5.6: Características físico-químicas e microbiológicas do esgoto no experimento V..71

Tabela 5.7: Características físico-químicas e microbiológicas do esgoto no experimento VI. 72

Tabela 5.8: Características físico-químicas e microbiológicas do esgoto no experimento VII.

Tabela 5.9: Características físico-químicas e microbiológicas do esgoto no experimento VIII. 
Tabela 5.10: Características físico-químicas e microbiológicas do esgoto no experimento IX.

Tabela 5.11: Análise estatística dos valores de $\mathrm{pH}$ do ensaio de cloração.............................. 75

Tabela 5.12: Análise estatística do Efluente Bruto e do clorado para a DQO. .......................76

Tabela 5.13: Análise estatística do efluente bruto e do efluente clorado para ST................... 80

Tabela 5.14: Análise estatística dos SST do efluente bruto e do efluente clorado...................82

Tabela 5.15: Variação do $\mathrm{pH}$, temperatura, $\mathrm{N}-\mathrm{NH}_{3}$ para efluente bruto (EB) e clorado (EC). 83

Tabela 5.16: Valores dos parâmetros cinéticos obtidos nos ensaios de desinfecção com cloro-

UV para C. perfringens.

Tabela 5.17: Valores dos parâmetros cinéticos obtidos nos ensaios de desinfecção com cloro-

UV para coliformes totais.

Tabela 5.18: Valores dos parâmetros cinéticos obtidos nos ensaios de desinfecção com cloro e

UV para E. coli.

Tabela 5.19: Valores de absorbância, $I_{m}$, dose recebida de UV e os respectivos tempos de contato da radiação UV.

Tabela 5.20: Produção do gerador de ozônio em função da vazão de gás e de tensão elétrica.

Tabela 5.21: Valores de Produção, dosagens e tempos de contato usados. .............................97

Tabela 5.22: Resultados do balanço de massa obtido nos ensaios com ozônio. .......................97

Tabela 5.23: Características físico-químicas e microbiológicas do esgoto no experimento 0.98

Tabela 5.24: Características físico-químicas e microbiológicas do esgoto no experimento I.. 99

Tabela 5.25: Características físico-químicas e microbiológicas do esgoto no experimento II.99

Tabela 5.26: Características físico-químicas e microbiológicas do esgoto no experimento III-

A.

Tabela 5.27: Características físico-químicas e microbiológicas do esgoto no experimento III-

B. 100

Tabela 5.28: Características físico-químicas e microbiológicas do esgoto no experimento IV.

Tabela 5.29: Características físico-químicas e microbiológicas do esgoto no experimento VA.

Tabela 5.30: Características físico-químicas e microbiológicas do esgoto no experimento V-B.

Tabela 5.31: Características físico-químicas e microbiológicas do esgoto no experimento VI. 
Tabela 5.32: Características físico-químicas e microbiológicas do esgoto no experimento VII.

Tabela 5.33: Características físico-químicas e microbiológicas do esgoto no experimento VIII.

Tabela 5.34: Características físico-químicas e microbiológicas do esgoto no experimento IX.

Tabela 5.35: Resumo estatístico dos valores de $\mathrm{pH}$ de todos os experimentos de desinfecção com ozônio.

Tabela 5.36: Análise estatística do Efluente Bruto e do ozonizado para a DQO. 107

Tabela 5.37: Análise estatística do efluente bruto e do efluente ozonizado para ST. 108

Tabela 5.38: Análise estatística dos SST do efluente bruto e do efluente ozonizado. 109

Tabela 5.39: Parâmetros cinéticos obtidos nos ensaios de desinfecção seqüencial ozônio-UV para C. perfringens. 116

Tabela 5.40: Parâmetros cinéticos obtidos nos ensaios de desinfecção seqüencial ozônio-UV para coliformes totais.

Tabela 5.41: Valores dos parâmetros cinéticos obtidos nos ensaios de desinfecção seqüencial de ozônio-UV para E. coli.

Tabela 5.42: Valores de absorbância a 254nm, Im, dose de UV e tempo de contato dos experimentos de desinfecção com ozônio seguido de UV. 


\section{Lista de Abreviaturas e Siglas}

$\alpha: \quad$ Coeficiente empírico

$\beta$ : $\quad$ Coeficiente empírico

$\lambda: \quad$ Comprimento de onda

Abs: $\quad$ Absorbância

AMP: $\quad$ Adenosina monofosfato

APHA: American Public Health Association

ATP: $\quad$ Adenosina Trifosfato

AWWA: American Water Works Association

CT: $\quad$ Concentração de desinfetante $\mathrm{x}$ tempo de contato, $[\mathrm{M}] .\left[\mathrm{L}^{-3}\right] .[\mathrm{T}]$

C: $\quad$ Concentração de Ozônio Consumido, $[\mathrm{M}] .\left[\mathrm{L}^{-3}\right]$

CETESB: Companhia de Tecnologia de Saneamento Ambiental

Cp: $\quad$ Clostridium perfringens

Ctotais: Coliformes Totais

DBO: $\quad$ Demanda Bioquímica de Oxigênio, [M]. [ $\left[\mathrm{L}^{-3}\right]$

DNA: $\quad$ Ácido Desoxirribonucléico

DQO: Demanda Química de Oxigênio, $[\mathrm{M}]$. $\left[\mathrm{L}^{-3}\right]$

Dr: $\quad$ Dose de radiação UV recebida

DRCM: Differential Reinforced Clostridial Medium (Meio enriquecido para determinação de clostrídios)

E.c: $\quad$ Escherichia coli

EB: $\quad$ Efluente anaeróbio Bruto

EC: $\quad$ Efluente anaeróbio Clorado

EESC: $\quad$ Escola de Engenharia de São Carlos

Ef (\%): $\quad$ Eficiência de remoção

EO: $\quad$ Efluente anaeróbio Ozonizado

ETE: $\quad$ Estação de Tratamento de Esgoto

EUV $_{(\mathrm{i})}$ : $\quad$ Efluente anaeróbio submetido à radiação $U V$, o índice i refere-se à primeira, segunda e terceira dose de UV

I: $\quad$ Intensidade de energia de radiação UV $\left(\mathrm{mW} / \mathrm{cm}^{2}\right)$

$\mathrm{I}_{\mathrm{m}}$ : Intensidade média de radiação $\mathrm{UV}\left(\mathrm{mW} / \mathrm{cm}^{2}\right)$

$\mathrm{I}_{\mathrm{o}}$ : Intensidade de radiação emitida pela fonte $\left(\mathrm{mW} / \mathrm{cm}^{2}\right)$ 
$\mathrm{K}: \quad$ Constante de decaimento, $\left[\mathrm{T}^{-1}\right]$

LATAR: Laboratório de Tratamento Avançado e Reuso de Águas

m: Coeficiente empírico

$\mathrm{M}_{\mathrm{A}}$ : $\quad$ Massa de Ozônio Aplicada, [M]

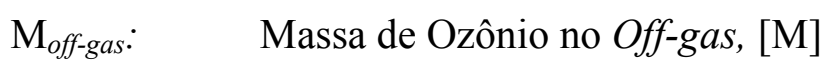

$\mathrm{M}_{\mathrm{R}}$ : $\quad$ Massa de Ozônio Residual, [M]

$\mathrm{M}_{\mathrm{T}}$ : $\quad$ Massa de Ozônio Transferida, [M]

n: $\quad$ Coeficiente de diluição

$\mathrm{N}$ : $\quad$ Concentração de microrganismos após tempo $\mathrm{t}$

Nm: Número de organismos não associados à matéria particulada

NMP: $\quad$ Número Mais Provável

No: $\quad$ Concentração inicial de microrganismos

Np: $\quad$ Número de organismos associados à matéria particulada, não afetada pela radiação UV

$\left[\mathrm{O}_{3}\right]_{\text {off-gas: }}$ Concentração de Ozônio no Off-gas, $[\mathrm{M}] .\left[\mathrm{L}^{-3}\right]$

$\left[\mathrm{O}_{3}\right]_{\mathrm{R}}: \quad$ Concentração de Ozônio Residual, $[\mathrm{M}] .\left[\mathrm{L}^{-3}\right]$

P: $\quad$ Produção de Ozônio

Q: $\quad$ Vazão de Ozônio, $\left[\mathrm{L}^{-3}\right] \cdot\left[\mathrm{T}^{-1}\right]$

RNA: Ácido Ribonucléico

SST: $\quad$ Sólidos Suspensos Totais, $[\mathrm{M}] .\left[\mathrm{L}^{-3}\right]$

ST: $\quad$ Sólidos Totais, $[\mathrm{M}] \cdot\left[\mathrm{L}^{-3}\right]$

t: $\quad$ Tempo de contato, $[\mathrm{T}]$

T: $\quad$ Temperatura, ${ }^{\circ} \mathrm{C}$

UASB: Upflow Anaerobic Sludge Blanket/ reator anaeróbio de fluxo ascendente com manta de lodo

UFC: $\quad$ Unidades Formadoras de Colônia

USEPA: U.S. Environmental Protection Agency

USP: $\quad$ Universidade de São Paulo

UV: $\quad$ Ultravioleta

WEF: Water Environmental Federation

WERF: Water Environmental Research Foudation 


\section{Resumo}

LOURENÇÃO, J. (2009). Avaliação da Resistência de Microrganismos Patogênicos à Desinfecção Sequencial com Ozônio-Radiação Ultravioleta e Cloro-Radiação Ultravioleta. São Carlos, 2009. 141p. Dissertação (Mestrado) - Escola de Engenharia de São Carlos, Universidade de São Paulo.

A remoção de microrganismos patogênicos através da desinfecção é uma necessidade para diminuir a incidência de doenças na população humana relacionadas com poluição fecal. A desinfecção sequencial tem grande potencial na remoção de microrganismos, quando comparada com a desinfecção convencional (um desinfetante). Neste trabalho buscou-se comparar a resistência de microrganismos indicadores de bactérias - E. coli e coliformes totais - e bactérias esporuladas - Clostridium perfringens quanto à desinfecção sequencial empregando cloro seguido de radiação ultravioleta e ozônio seguido de radiação ultravioleta; e à desinfecção convencional utilizando-se os mesmos desinfetantes aplicados individualmente em esgoto sanitário tratado previamente em reator UASB. Os ensaios foram realizados em batelada. As dosagens de cloro aplicadas foram de 10,20 e $30 \mathrm{mgCl}_{2} / \mathrm{L}$; de ozônio foram de 5,6;11 e 16,5 $\mathrm{mgO}_{3} / \mathrm{L}$, ambos para os tempos de contato 10, 20 e 30 minutos. Na desinfecção sequencial com cloro foram aplicadas as doses de 1,5 e $10 \mathrm{Wh} / \mathrm{m}^{3}$ de radiação UV; com ozônio, as doses de radiação foram variadas de 0,5 a $10 \mathrm{Wh} / \mathrm{m}^{3}$. Na desinfecção sequencial de cloro-UV, foram removidos 2,5 e 5,2 log de C. perfringens e coliformes totais, respectivamente contra 1,5 e 4,2 log na desinfecção convencional para os mesmos microrganismos. Na desinfecção com cloro, a ordem decrescente de resistência foi: C. perfringens $>$ coliformes totais $>E$. coli. Para ozônio seguido de UV, C. perfringens apresentou maior resistência e, em alguns ensaios, E. coli apresentou-se mais resistente que coliformes totais. A ação do ozônio mostrou-se notável para a melhoria da qualidade do esgoto tratado avaliada pela diminuição das concentrações de sólidos suspensos totais, sólidos totais, absorbância em comprimento de onda de $254 \mathrm{~nm}$ e da DQO, diferentemente do esgoto clorado no qual ocorreu o aumento nos valores destas variáveis físico-químicas. A ação da radiação ultravioleta foi potencializada quando aplicada sequencialmente ao cloro e ao ozônio.

Palavras-chave: Desinfecção sequencial, esgoto sanitário, cloro, ozônio, radiação ultravioleta, Escherichia coli, coliformes totais, Clostridium perfringens. 
Abstract

LOURENÇÃO, J. (2009). Resistance Evaluation of Pathogenic Microorganisms to Sequential Disinfection with Ozone- Ultraviolet Radiation and Chlorine- Ultraviolet Radiation. São Carlos, 2009. 141p. Master's Degree Dissertation - Escola de Engenharia de São Carlos, Universidade de São Paulo.

The removal of pathogenic microorganisms through disinfection is a necessity to decrease the incidence of diseases in the human population related to fecal pollution. Sequential disinfection has a great potential on the removal of microorganisms when compared to conventional disinfection (single disinfectant). This work compared the resistance of indicators microorganisms of bacteria - E. coli and total coliforms - and spore-forming bacteria - Clostridium perfringens concerning the sequential and conventional disinfections. The sequential disinfection initially employed chlorine followed by ultraviolet radiation and ozone followed by ultraviolet radiation. The conventional disinfection utilized the same disinfectants individually applied in sanitary sewage previously treated in UASB reactor. The tests were made in batch. The chlorine dosages applied were 10,20 and $30 \mathrm{mgCl}_{2} / \mathrm{L}$; ozone were 5,$6 ; 11$ and $16,5 \mathrm{mgO}_{3} / \mathrm{L}$, both for the contact times 10,20 and 30 minutes. In the sequential disinfection with chlorine dosages of 1,5 and $10 \mathrm{Wh} / \mathrm{m}^{3}$ of UV radiation were applied; with ozone, the dosages of radiation varied from 0,5 to $10 \mathrm{Wh} / \mathrm{m}^{3}$. In the sequential disinfection with UV-chlorine were inactived 2,5 and 5,2 $\log$ of $C$. perfringens and total coliforms respectively, against 1,5 and $4,2 \log$ in the conventional disinfection for the same microorganisms. In the chlorine disinfection, the decreasing resistance order was: $C$. perfringens $>$ total coliforms $>E$. coli. In the ozone disinfection followed by UV, $C$. perfringens manifested more resistance and, in some assays, E. coli was more resistant than total coliforms. The action of ozone was outstanding for the improvement of treated sewage quality assessed by the decreasing of total suspended solids concentration, total solids absorbance at a wavelength of $254 \mathrm{~nm}$ and of DQO, differently from the chlorine sewage in which occurred an increase of the values of the physical-chemical variables. The ultraviolet radiation action was potentiated when sequentially applied to chlorine and to ozone.

Key Words: Sequential disinfection, sanitary sewage, chlorine, ozone, ultraviolet radiation, Escherichia coli, total coliforms, Clostridium perfringens. 


\section{Introdução}

Ainda é uma realidade em muitos municípios brasileiros e em diversos locais do mundo a dificuldade em se tratar o esgoto sanitário facilitando a exposição das pessoas a recursos naturais contaminados por fezes, podendo ocasionar diversos danos à saúde pública. Isso ocorre devido à condição econômica desfavorável ou a problemas estruturais políticos enfrentados pelas administrações locais.

As doenças podem apresentar modos múltiplos de transmissão que se realizam por meio do consumo de água, transmissão entre pessoas, consumo de alimentos contaminados, contato primário com corpos receptores, entre outros. Desta forma, o controle da disseminação das doenças de veiculação hídrica vincula-se à proteção dos mananciais e à desinfecção tanto de águas de abastecimento quanto residuárias. A proteção dos mananciais superficiais é feita a partir do constante monitoramento das características das águas naturais combinado à inativação dos patogênicos por diferentes métodos de desinfecção da água residuária. A importância da desinfecção no tratamento destas águas pode ser entendida como a última barreira de proteção contra os microrganismos patogênicos (WEF, 1996).

Grandes volumes de esgoto têm sido despejados em múltiplos locais de descarga e a autodepuração dos corpos d' água é insuficiente para reduzir a quantidade de microrganismos patogênicos. Combinando-se o fato da incapacidade de reduzir o elevado número destes microrganismos naturalmente ao fato de que o tratamento de esgotos sem desinfecção não promove a redução substancial destes organismos, torna-se necessária a desinfecção para reduzir a transmissão de doenças infecciosas e proteger a saúde pública (WEF, 1996).

A qualidade de um corpo d'água está ligada ao uso e ocupação que se faz do solo com os conseqüentes impactos das atividades humanas e da contaminação produzida por atividades industriais e agrícolas. O esgoto despejado in natura ou insuficientemente tratado contém elevada carga de organismos patogênicos, entre eles, bactérias, vírus e protozoários.

Esses organismos, que sobrevivem no ambiente externo ao corpo do hospedeiro, aumentam em quantidade e distribuição espacial em regiões com alta concentração populacional, intensificação de atividades humanas, como pecuária, agricultura ou atividades industriais (TUNDISI, 2003).

Destaca-se, portanto, a importância do esgoto sanitário na veiculação de diversos microrganismos patogênicos, evidenciando a necessidade do controle da qualidade das águas 
utilizadas para recreação, irrigação e fontes de abastecimento para consumo humano. (GONÇALVES et al., 2003).

A demanda de água potável, o intensivo lançamento de esgoto sanitário sem tratamento adequado e sua correspondente diminuição de fontes de água seguras para o consumo humano têm se tornado uma contínua preocupação da comunidade acadêmica e está se popularizando, pois as consequências da poluição por esgoto sanitário causam, além das doenças, a depleção dos níveis de oxigênio dos corpos d'água, ocasionando a morte de organismos aquáticos por asfixia e, conseqüentemente, causando prejuízos econômicos, danos aos propósitos de recreação e efeitos desagradáveis de odor e visual.

O desempenho de determinado processo de desinfecção depende da resistência específica dos diferentes organismos patogênicos ao desinfetante, considerando-se que os organismos presentes no esgoto possuem sensibilidades diferentes ao tipo e dose dos diversos agentes desinfetantes. Por exemplo, o ozônio é mais eficiente como agente desinfetante viral. Portanto, o uso de desinfetantes combinados (usados sequencialmente ou simultaneamente) vem atender diretamente a essas necessidades (VESCHETTI et al., 2003, SARTORI \& DANIEL, 2003, TYRRELL et al., 1995, HARAKEH, 1987).

No presente trabalho, foram escolhidos, além do cloro que já é um desinfetante largamente utilizado em todo o mundo e principal agente desinfetante de água e esgoto no Brasil, outros desinfetantes alternativos. Os outros desinfetantes utilizados foram o ozônio e radiação UV. A desinfecção sequencial foi configurada em: cloro seguido de radiação UV e ozônio seguido de radiação UV, na qual foi explorada a resistência de certas bactérias. 


\section{Objetivos}

\subsection{Objetivo principal}

Comparar a resistência dos microrganismos coliformes totais, Escherichia coli $e$ Clostridium perfringens quanto à desinfecção sequencial ozônio-radiação ultravioleta e clororadiação ultravioleta.

\subsection{Objetivos específicos}

* Comparar a resistência dos coliformes totais, E. coli e C. perfringens quando submetidos à desinfecção convencional com cloro, ozônio e radiação ultravioleta e à desinfecção seqüencial cloro-radiação ultravioleta e ozônio-radiação ultravioleta;

* Comparar os efeitos do cloro e do ozônio sobre a qualidade da água residuária da ETE do campus da EESC-USP São Carlos (SP);

* Comparar os desinfetantes quanto aos efeitos na qualidade do efluente desinfetado. 


\section{Revisão Bibliográfica}

O lançamento de esgoto sem tratamento ou tratado inadequadamente pode produzir uma ou mais das seguintes situações indesejadas (PELCZAR et al., 1996):

1. Maior possibilidade para a disseminação de microrganismos patogênicos;

2. Maior perigo na utilização das extensões naturais de água como suprimento potável;

3. A contaminação de ostras e outros moluscos pela poluição, tornando-os impróprios para o consumo humano;

4. Grandes perdas na população de aves aquáticas devido à contaminação de suas fontes nutritivas;

5. Maior risco microbiológico em nadar em águas poluídas e diminuição de seu valor para outros propósitos recreativos;

6. Depleção do suprimento de oxigênio da água pela presença de matéria orgânica instável no esgoto, prejudicando a sobrevivência dos seres vivos aquáticos;

7. Ação de uma série de condições desagradáveis, tais como odores e acúmulo de detritos, com redução dos valores de propriedade e utilidades recreativas.

\subsection{Controle de microrganismos}

A condição sanitária de uma população é determinada, em larga escala, por sua capacidade de controlar eficazmente as populações microbianas. Cuidados diários, tais como a purificação da água e a preservação de alimentos, concorrem para o controle das populações microbianas. Não somente torna-se o produto de consumo seguro sob o ponto de vista de saúde pública, como também, traz o processo muitos benefícios para o bem estar da comunidade (PELCZAR et al., 1980).

As principais razões para desenvolver o controle de microrganismos nocivos são prevenir a transmissão de doenças e a contaminação ou seu crescimento (PELCZAR et al., 1980).

\subsubsection{Condições que influenciam a ação antimicrobiana}

Segundo PELCZAR et al., (1980) alguns fatores que influenciam a ação antimicrobiana são:

1. Temperatura - o aumento da temperatura, quando usado em combinação com outro agente, acelera a destruição de microrganismos. 
2. Tipo de microrganismo - as espécies de microrganismos diferem em sua susceptibilidade aos agentes físicos e químicos. Nas espécies que formam esporos, as formas vegetativas são muito mais sensíveis que as formas esporuladas.

3. Estado fisiológico das células - células jovens, metabolicamente ativas, são mais facilmente destruídas que as células velhas ou em latência se o agente nocivo agir através de uma interferência sobre o metabolismo (assim, as células que não estão crescendo não seriam afetadas). Alterações na natureza da membrana celular, capazes de modificar a permeabilidade celular, podem contribuir para a existência de diferenças na resistência bacteriana.

4. Condições ambientais - as propriedades físicas e químicas do meio ou da substância que sustentam os microrganismos, isto é, o meio ambiente, têm profunda influência na destruição microbiana.

5. Condições operacionais- tempo de contato com o desinfetante, intensidade do agente físico ou químico, concentração de microrganismos.

O mecanismo de ação do desinfetante deve seguir a sequência de eventos de interação do desinfetante com a superfície da célula seguido da penetração para o interior da célula e posterior ação no sítio alvo (MCDONNELL \& RUSSELL, 1999). Segundo os mesmos autores, a resposta ao antisséptico ou desinfetante varia para diferentes organismos. A resposta dos vários organismos pode estar associada à estrutura celular diferenciada, composição e fisiologia.

Para moléculas de antissépticos e desinfetantes alcançarem seu sítio alvo, as camadas mais externas das células devem ser cruzadas. A natureza e composição destas camadas dependem do tipo de organismo e podem atuar como barreira para a permeabilidade, na qual pode haver redução de tomada (uptake). Alternativamente, mas menos comumente, enzimas sintetizadas pelos organismos podem degradar alguns compostos. Bactérias Gram-negativas tendem ser mais resistentes que organismos Gram- positivos (MCDONNELL \& RUSSELL, 1999).

Esporos das bactérias do gênero Bacillus e Clostridium têm sido estudados e são os mais resistentes aos antissépticos e desinfetantes que todos os tipos de bactérias (BLOOMFIEID, 1999; SAGRIPANTI \& BONIFACIO, 1996; RUSSELL, 1990; FOEGEDING \& BUSTA, 1983).

A resistência pode estar associada com enzimas degradativas, mas está mais associada com a impermeabilidade celular. As camadas e o córtex em esporos, e possivelmente outros 
componentes da membrana mais externa de bactérias Gram-negativas, limitam a concentração de biocida ativo que possa alcançar o sítio alvo nestas células bacterianas (RUSSELL, 1999).

\subsection{Doenças - relacionadas à poluição fecal}

As doenças infecciosas de fonte comum são causadas pela contaminação microbiana de materiais partilhados por um grande número de indivíduos. Tais fontes comuns de doenças correspondem à água e alimentos contaminados. Estas enfermidades correspondem a uma causa significativa de morbidade e mortalidade, especialmente em países em desenvolvimento (MADIGAN, 2004).

Os microrganismos veiculados pela água e alimentos geralmente se desenvolvem no intestino e são eliminados pelas fezes. Conseqüentemente, caso estes microrganismos não sejam detectados (como, por exemplo, por meio de exames) e eliminados pela desinfecção ou por medidas corretas de cocção e manuseio dos alimentos, um novo hospedeiro pode vir a consumir desta água ou alimento permitindo que o patógeno colonize seu intestino causando doenças.

O cozimento inadequado, a manipulação ou o armazenamento impróprio, assim como, as condições sanitárias deficientes durante o preparo dos alimentos podem causar de um simples desconforto intestinal a doenças graves devido à presença de microrganismos patogênicos (PELCZAR et al., 1996).

Duas grandes categorias de doenças microbianas transmitidas por alimentos são: intoxicação alimentar e infecções transmitidas por alimentos (PELCZAR et al., 1996). A intoxicação alimentar ocorre após a ingestão de alimentos contaminados com toxinas produzidas por microrganismos, sendo essa toxina a responsável pelos sintomas clínicos. Já as infecções transmitidas por alimentos ocorrem quando o patógeno é ingerido e se multiplica dentro dos organismos. Tais infecções causam usualmente doenças do trato intestinal, embora outras áreas do corpo possam ser afetadas.

A infecção veiculada pela água ocorre quando o microrganismo infeccioso é adquirido através de água contaminada por material fecal, contendo patógenos de humanos ou de animais. Quando esses patógenos de humanos contaminam a rede de abastecimento público ou outras fontes de água potável utilizadas por muitas pessoas, podem ocorrer surtos de doenças intestinais, afetando um grande número de pessoas em curto período de tempo (PELCZAR et al., 1996).

Medidas preventivas relacionadas ao saneamento podem evitar a disseminação dessas doenças, prevenindo a contaminação de fontes de alimento e água (PELCZAR et al., 1996). 
A poluição fecal pode adicionar à água uma variedade de microrganismos patogênicos intestinais. Em qualquer momento, estes agentes poderão estar presentes na água por recebimento de fezes de animais de sangue quente (CETESB, 1974).

Os microrganismos de maior importância para o homem, relacionados à contaminação por esgotos, são as bactérias, vírus entéricos e parasitas intestinais. Doenças que são espalhadas pelo consumo de água e/ ou contato direto podem ser severas e muitas vezes muito danosas (WEF, 1996).

Algumas doenças contraídas por contato direto ou consumo de água contaminada por esgotos (água potável e/ou recreacional) estão resumidas na Tabela 3.1.

Tabela 3.1: Doenças potencialmente relacionadas à água contaminada

\begin{tabular}{|c|c|c|c|}
\hline Bactérias & Vírus & Protozoários & Helmintos \\
\hline $\begin{array}{c}\text { Gastroenterites } \\
\text { (diversos grupos de } \\
\text { bactérias) }\end{array}$ & $\begin{array}{l}\text { Poliomielite } \\
\text { (Poliovirus) }\end{array}$ & $\begin{array}{l}\text { Giárdia (Giardia } \\
\text { lamblia) }\end{array}$ & $\begin{array}{l}\text { Schistosomose } \\
\text { (Schistosoma } \\
\text { mansoni) }\end{array}$ \\
\hline $\begin{array}{c}\text { Febre tifóide } \\
\text { (Salmonella typhi) }\end{array}$ & $\begin{array}{l}\text { Conjuntivites } \\
\text { hemorrágicas }\end{array}$ & $\begin{array}{c}\text { Disenteria amebiana } \\
\text { (Entamoeba } \\
\text { histolytica) }\end{array}$ & $\begin{array}{l}\text { Ascaridiase (Ascaris } \\
\text { lumbricoides) }\end{array}$ \\
\hline $\begin{array}{l}\text { Disenteria bacilar } \\
\quad \text { (Shigella) }\end{array}$ & $\begin{array}{l}\text { Hepatite (vírus da } \\
\text { hepatite) }\end{array}$ & $\begin{array}{c}\text { Criptosporidiase } \\
\text { (Cryptosporidium } \\
\text { parvum e C.hominis) }\end{array}$ & $\begin{array}{l}\text { Estrongiloidiase } \\
\text { (Strongyloides } \\
\text { stercoralis) }\end{array}$ \\
\hline Cólera (Vibrio colera) & $\begin{array}{l}\text { Gastroenterite } \\
\text { (Rotavirus) }\end{array}$ & & $\begin{array}{c}\text { Tricuríase } \\
\text { (Trichuris trichiura) }\end{array}$ \\
\hline \multicolumn{4}{|l|}{$\begin{array}{c}\text { Doenças pulmonares } \\
\text { (Mycobacteria) }\end{array}$} \\
\hline $\begin{array}{l}\text { Pneumonia } \\
\text { (Streptococcus } \\
\text { pneumoniae) }\end{array}$ & & & \\
\hline
\end{tabular}

Fonte: WEF (1996) e SPELLMAN (1999) modificados.

A ocorrência e densidade de agentes patogênicos são muito variadas em água poluída e em fezes de animais. Esta variabilidade reflete as doenças intestinais que são prevalentes, num dado momento, nas populações humanas ou animal, as quais contribuem com seus resíduos num efluente particular ou na bacia hidrográfica (CETESB, 1974).

Os agentes patogênicos de humanos são também encontrados com freqüência no trato intestinal de outros animais de sangue quente, incluindo animais domésticos, gado, aves domésticas e animais silvestres. Estes microrganismos podem ser adquiridos através da água e alimentos contaminados. Tais animais podem se tornar infectados por estes agentes ou servir 
de hospedeiro. Mesmo os peixes podem se tornar infectados ativamente com microrganismos patogênicos de humanos após contato com água contaminada e levar estes agentes a cursos de água limpa de áreas recreacionais (CETESB, 1974).

A diversidade de microrganismos presentes no esgoto sanitário implica em características bioquímicas diferentes entre si, resultando em divergência de comportamento quando elementos externos são introduzidos. É o caso, por exemplo, da variação da temperatura, pH ou ainda a aplicação de agentes de inativação distintos como o ozônio e a radiação ultravioleta (WEF, 1996).

\subsection{Microrganismos Indicadores de poluição fecal}

A detecção direta de bactérias patogênicas, vírus e cistos de protozoários requer procedimentos custosos, demorados e laboratoristas bem treinados. Estes requerimentos induziram a concepção de organismos indicadores de poluição fecal. Em 1914, o Serviço de Saúde Pública Norte Americano adotou o grupo coliforme como um indicador de contaminação fecal em água potável. Mais tarde, outros organismos passaram a ser usados para indicar a ocorrência de contaminação fecal, a eficiência do tratamento de estações de tratamento de água e esgoto e a deterioração e pós- contaminação do sistema de distribuição (OLIVIERI, $1983^{1}$ apud BITTON (1994).

Segundo BITTON (1994), os critérios para um organismo ser um indicador ideal são:

1. Este deve ser um membro da microbiota intestinal de animais de sangue quente;

2. Deve estar presente quando patógenos estão presentes e ausente em amostras não contaminadas;

3. Deve estar presente em grande número;

4. Assim como o patógeno, deve ter ao menos semelhante resistência ao estresse ambiental e aos sistemas de tratamento de água e esgoto;

5. Não deve multiplicar-se no ambiente;

6. Deve ser detectado por métodos fáceis, rápidos e não custosos;

7. O organismo indicador não deve ser patogênico.

\footnotetext{
${ }^{1}$ OLIVIERI, V. P. 1983. Measurement of Microbial Quantity in: Assessment of Microbiology and Turbidity Standards for Drinking Water, P. S. Berger and Y Argaman, Eds. EPA-570-9-83-001, Office of Drinking Water, Washington, DC.
} 
Na Tabela 3.2 estão apresentados os organismos utilizados como indicadores, suas vantagens e limitações.

Tabela 3.2: Principais microrganismos que têm sido propostos para serem usados como indicadores

\begin{tabular}{|c|c|c|c|c|}
\hline $\begin{array}{c}\text { Organismo } \\
\text { indicador }\end{array}$ & $\begin{array}{l}\text { Indicador de } \\
\text { contaminação }\end{array}$ & Bom indicador & Não indicado & Técnicas \\
\hline $\begin{array}{l}\text { Bactérias } \\
\text { coliformes }\end{array}$ & $\begin{array}{l}\text { Contaminação de origem } \\
\text { fecal e não fecal. }\end{array}$ & $\begin{array}{l}\text { Bactérias entéricas, } \\
\text { alguns vírus e } \\
\text { microrganismos } \\
\text { menos resistentes que } \\
\text { esse grupo. }\end{array}$ & $\begin{array}{l}\text { Bactérias esporuladas, } \\
\text { vírus, helmintos, } \\
\text { protozoários e todos os } \\
\text { microrganismos mais } \\
\text { resistentes. }\end{array}$ & $\begin{array}{l}\text { Várias técnicas de } \\
\text { fermentação podem ser } \\
\text { feitas apresentando } \\
\text { resultados em } 24 \mathrm{~h}^{\mathrm{c}} \text {. }\end{array}$ \\
\hline $\begin{array}{l}\text { Bactérias do } \\
\text { grupo } \\
\text { coliformes } \\
\text { fecais }\end{array}$ & $\begin{array}{l}\text { Contaminação de origem } \\
\text { fecal }^{\text {a }} \text {, são bons } \\
\text { indicadores para águas } \\
\text { balneárias. }\end{array}$ & $\begin{array}{l}\text { Bactérias entéricas, } \\
\text { alguns vírus e } \\
\text { microrganismos } \\
\text { menos resistentes que } \\
\text { esse grupo. }\end{array}$ & $\begin{array}{l}\text { Bactérias esporuladas, } \\
\text { vírus, helmintos, } \\
\text { protozoários e todos os } \\
\text { microrganismos mais } \\
\text { resistentes. }\end{array}$ & $\begin{array}{l}\text { Várias técnicas de } \\
\text { fermentação podem ser } \\
\text { feitas apresentando } \\
\text { resultados em } 24 \mathrm{~h}^{\mathrm{c}} .\end{array}$ \\
\hline Klebsiella & $\begin{array}{l}\text { Contaminação de origem } \\
\text { fecal e não fecal, é o } \\
\text { principal componente da } \\
\text { população de coliformes } \\
\text { na vegetação e em } \\
\text { resíduos de indústrias de } \\
\text { papel, têxtil e outros. }\end{array}$ & $\begin{array}{l}\text { Recrescimento de } \\
\text { coliformes em } \\
\text { sistemas de } \\
\text { distribuição de água. }\end{array}$ & $\begin{array}{l}\text { Bactérias esporuladas, } \\
\text { vírus, helmintos, } \\
\text { protozoários e todos os } \\
\text { microrganismos mais } \\
\text { resistentes. }\end{array}$ & $\begin{array}{l}\text { Rápidas quantificações } \\
\text { podem ser feitas } \\
\text { utilizando filtração em } \\
\text { membranas }\end{array}$ \\
\hline E. coli & $\begin{array}{c}\text { Poluição recente de } \\
\text { origem exclusivamente } \\
\text { fecal. }\end{array}$ & $\begin{array}{c}\text { Bactérias entéricas de } \\
\text { origem humana, } \\
\text { vírus, e } \\
\text { microrganismos } \\
\text { menos resistentes. }\end{array}$ & $\begin{array}{l}\text { Bactérias esporuladas, } \\
\text { vírus, helmintos, } \\
\text { protozoários e todos os } \\
\text { microrganismos mais } \\
\text { resistentes. }\end{array}$ & $\begin{array}{c}\text { Pode ser feito com a } \\
\text { técnica de filtração em } \\
\text { membranas e ainda o } \\
\text { método Collilert }{ }^{\mathrm{c}} \text {, } \\
\text { simples e rápidos, que } \\
\text { oferecem resultados em } \\
24 \mathrm{~h} \text {. }\end{array}$ \\
\hline $\begin{array}{l}\text { Streptococcus } \\
\text { faecalis }\end{array}$ & $\begin{array}{l}\text { Determina a fonte da } \\
\text { recente contaminação } \\
\text { fecal, se é de origem } \\
\text { humana ou animal. Vem } \\
\text { surgindo como boa } \\
\text { alternativa devido a sua } \\
\text { maior resistência quando } \\
\text { comparado aos } \\
\text { coliformes fecais. }\end{array}$ & $\begin{array}{l}\text { Bactérias entéricas de } \\
\text { origem animal, } \\
\text { alguns vírus }{ }^{\mathrm{b}} \mathrm{em} \\
\text { águas pouco } \\
\text { contaminadas e } \\
\text { microrganismos } \\
\text { menos resistentes. }\end{array}$ & $\begin{array}{l}\text { Bactérias esporuladas, } \\
\text { vírus, helmintos, } \\
\text { protozoários e todos os } \\
\text { microrganismos mais } \\
\text { resistentes. }\end{array}$ & $\begin{array}{l}\text { Resultados podem ser } \\
\text { conseguidos utilizando a } \\
\text { técnica de tubos } \\
\text { múltiplos ou filtração em } \\
\text { membranas. }\end{array}$ \\
\hline Colifagos & $\begin{array}{l}\text { Poluição de origem fecal. } \\
\text { É bastante utilizado na } \\
\text { avaliação da qualidade de } \\
\text { água. }\end{array}$ & Vírus. & $\begin{array}{l}\text { Helmintos, } \\
\text { protozoários e todos os } \\
\text { microrganismos mais } \\
\text { resistentes. }\end{array}$ & $\begin{array}{c}\text { Fornece resultados após } \\
\text { um tempo mínimo de } 4 \text { a } \\
6 \text { horas }{ }^{c} \text {. A quantificação } \\
\text { de colifagos é obtida } \\
\text { pela contagem de placa } \\
\text { de lise utilizadas por } \\
\text { amostra. }\end{array}$ \\
\hline $\begin{array}{l}\text { Clostridium } \\
\text { perfringens }\end{array}$ & $\begin{array}{l}\text { Ótimo indicador de } \\
\text { contaminação fecal onde } \\
\text { foi empregado a } \\
\text { desinfecção, ou onde há } \\
\text { poluição remota. }\end{array}$ & Protozoários. & $\begin{array}{l}\text { Helmintos e todos os } \\
\text { microrganismos mais } \\
\text { resistentes. }\end{array}$ & $\begin{array}{l}\text { Pode ser feito com a } \\
\text { técnica de filtração em } \\
\text { membranas }{ }^{\mathrm{d}} \text { e ainda pela } \\
\text { técnica de tubos } \\
\text { múltiplos }{ }^{\mathrm{ce} e} \text {. }\end{array}$ \\
\hline
\end{tabular}

Fonte: Organizado por DIAS, 2001, adaptado de WEF (1996); USEPA (1999); LIMA et al. (1999); APHA (1995); APHA (1998).

${ }^{a}$ A sua especificidade como indicador de contaminação fecal é comprometida pelo fato da existência nesse grupo de alguns coliformes que não são de origem exclusivamente fecal.

${ }^{\mathrm{b}}$ Por apresentarem maior tempo de sobrevivência e maior resistência aos processos de tratamento, que o grupo dos coliformes, porém o seu uso pode ser questionado.

${ }^{\mathrm{c}}$ Conforme descrito no Standard Methods, 1998.

${ }^{\mathrm{d}}$ Norma da CETESB L5.403/2004.

e Norma da CETESB L5.213/1993. 
Nos itens subseqüentes, (3.4.1; 3.4.1.1 e 3.4.2) está apresentada uma breve descrição dos indicadores usados na presente dissertação.

\subsubsection{Coliformes totais}

Os coliformes são definidos na bacteriologia como o grupo que agrega as seguintes características: são bacilares, o grupo inclui bactérias aeróbias e anaeróbias facultativas, Gram-negativas, não formadoras de esporos que fermentam lactose com a produção de gás em $48 \mathrm{~h}$ a $35^{\circ} \mathrm{C}$ (APHA, 1989; MADIGAN, 2004).

Este grupo inclui uma variedade de organismos, a maioria pertencente ao grupo das bactérias entéricas. O grupo dos coliformes inclui Escherichia coli, Enterobacter, Klebsiella e Citrobacter. Estes coliformes são lançados em altos números ( em média $2 \times 10^{9}$ coliformes por dia per capita) em fezes humanas e animais, mas nem todas são de origem fecal (APHA, 1989, MADIGAN, 2004). Esses indicadores são úteis para determinar a qualidade de água potável, água de cultivo de mariscos e águas recreacionais. Em estações de tratamento de água em consonância com a Resolução No. 357/2005 e a Portaria 518/2004, coliformes totais juntamente à $E$. coli são os microrganismos indicadores de eficiência do tratamento e ditam a qualidade da água para consumo humano.

São utilizados como indicadores de contaminação de água, uma vez que estão presentes em grandes quantidades no trato intestinal de seres humanos e de outros animais. São usados também como indicadores para avaliar a eficiência de sistemas de desinfecção. No entanto este organismo como indicador pode não ser suficiente para assegurar a ausência de microrganismos patogênicos na água. Ainda mais, muitas vezes águas que não contêm coliformes podem estar contaminados com vírus e cistos de protozoários, os quais são mais resistentes às condições adversas do meio ambiente (DIAS, 2001).

\subsubsection{Escherichia coli}

Muitas cepas de E. coli são encontradas no trato gastrointestinal de humanos e animais de sangue quente. Entretanto, muitas destas cepas podem ser inofensivas (BITTON, 1994).

Há diversas categorias de cepas de E. coli que podem carregar fatores de virulência e causarem diarréia. Essas são cepas de E. coli enterotoxigênicas (ETEC), enteropatogências (EPEC), enteroemorrágicas (EAEC) e enteroenvasivas (BITTON, 1994).

A E. coli enterotoxigênicas causa gastroenterite com forte diarréia aquosa acompanhada de náuseas, cólicas estomacais e vômitos (BITTON, 1994). 
Aproximadamente $2 \%$ a $8 \%$ das E. coli presentes na água são patogênicas, causadoras de diarréia do viajante (BITTON, 1994).

Alimento e água são importantes na transmissão deste patógeno. De qualquer modo, a dose infectante para ele é relativamente alta, sendo na ordem de $10^{6}$ a $10^{9}$ organismos (BITTON, 1994).

\subsubsection{Clostridium perfringens}

Esses organismos são bactérias Gram-positivas anaeróbias, formadoras de esporo, sensíveis ao oxigênio e relativamente resistentes a estresse ambiental e à desinfecção (BITTON, 1994).

Essa bactéria é encontrada no solo, nos vegetais em putrefação, e faz parte da microbiota natural do trato intestinal de homens e animais (ROBERTS, 1974).

BITTON (1994) diz que os esporos tornam essa bactéria muito resistente para ser usada como um organismo indicador. É sugerido por este autor, no entanto, o uso deste microrganismo como um indicador de poluição remota e como um traçador de poluição fecal em ambientes marinhos.

Em contrapartida, MEDENA et al., (1997) constataram que esporos de C. perfringens apresentaram-se mais resistentes que oocistos de Criptosporidium parvum, analisando o decaimento natural desses organismos na água de um rio. Concordando com esses autores, XU et al., (2002) sugerem que, devido a sua alta resistência à desinfecção, o C. perfringens é um ótimo candidato a indicador de microrganismos resistentes. Foi concluído, portanto, que essa bactéria formadora de esporos é um parâmetro que poderia ser muito útil como indicador da presença do protozoário C. parvum.

\subsection{Desinfecção}

A desinfecção refere-se à inativação seletiva e/ou destruição de organismos causadores de doenças. Diferentemente de esterilização, que representa a destruição de todos os organismos, a desinfecção não destrói todos os organismos presentes (WERF, 1995).

Os organismos causadores de doenças são acompanhados por um largo número de espécies de organismos saprofíticos que não fazem mal à saúde humana e que são muito benéficos e essenciais para o tratamento biológico de esgotos (WEF, 1996). Assim, a desinfecção tem a finalidade de inativar de preferência os microrganismos patogênicos. Por esse motivo, recomenda-se que a desinfecção seja aplicada após a conclusão do tratamento biológico obtendo-se assim, maior aproveitamento e eficácia no tratamento de esgotos. 
As fezes do homem e os esgotos produzidos por ele são as maiores fontes de agentes patogênicos veiculados pela água. A monitoração de microrganismos patogênicos em esgoto tem se mostrado um excelente instrumento epidemiológico para determinar quais doenças podem ser prevalentes na comunidade em um dado momento (CETESB, 1974).

A desinfecção pode ser realizada com agentes químicos, radiação e meios mecânicos. Os agentes químicos usados como desinfetantes incluem cloro e seus compostos, iodo, ozônio, fenol e compostos fenólicos, alcoóis, metais pesados, sabões e detergentes sintéticos, compostos de amônia, peróxido de hidrogênio, e vários álcalis e ácidos. Dentre os diversos desinfetantes químicos, o cloro é o mais usado universalmente (WERF, 1995).

Bactérias e outros organismos podem ser removidos por meio mecânico, isto é, sedimentação e filtração durante o tratamento de esgoto sanitário. Os tipos de radiação incluem radiação ionizante (raios gama) (ELIASSEN \& TRUMP ${ }^{2}, 1974$ citado em WERF, 1995), eletromagnética (BROCK \& MADIGAN, $1988^{3}$ citado em WERF, 1995), radiação térmica (aquecimento de água a ponto de ebulição).

Os principais mecanismos que são propostos para explicar a ação dos desinfetantes incluem (SPELLMAN (1999), WERF, (1995)):

* Danos na parede celular;

* Alteração da permeabilidade celular;

* Inibição da conversão pela célula de alimento em energia;

* Alteração na natureza coloidal do protoplasma;

* Inibição enzimática;

* Inibição da reprodução por danos no DNA (ácido desoxirribonucléico) e RNA (ácido ribonucléico) celular (PELCZAR \& $\mathrm{CHAN}^{4}, 1986$ citado em WERF, 1995).

Danos ou destruição na parede celular podem resultar em lise celular e morte. Alguns agentes, como a penicilina, inibem a síntese da parede celular bacteriana. Compostos fenólicos e detergentes alteram a permeabilidade da membrana citoplasmática. Essas substâncias destroem a permeabilidade seletiva da membrana citoplasmática e permitem o escape de nutrientes vitais, tais como nitrogênio e fósforo. Calor, radiação e agentes altamente

\footnotetext{
${ }^{2}$ ELIASSEN, R \& TRUMP (1974) “ High-Energy Electrons Offer Alternative to Chlorine”, Calif. WPCA Bull. Vol. 10, no. 3. citado por WERF, 1995. DISINFECTION Comparison of UV Irradiation to Chlorination: Guidance for Achieving Optimal UV Performance. Water Environment Research Foundation. EUA.

${ }^{3}$ BROCK, T. D. \& MADIGAN, M. T. 1988, Biology of Microorganisms, 5th ed., Prentice Hall, Englewood Cliffs, NJ.

${ }^{4}$ PELCZAR, M. J. JR. \& CHAN, E. C. (1986). Microbiology, 5th ed., McGraw-Hill, New York, NY.
} 
ácidos ou alcalinos alteram a natureza coloidal do protoplasma. O calor coagula as proteínas celulares e os ácidos e bases a desnaturam, produzindo um efeito letal (WERF, 1995).

Embora a desinfecção de esgoto tenha sido praticada por muitos anos, sua aplicação nem sempre produziu o resultado final desejado. A aplicação conveniente precisa incluir o controle adequado da qualidade microbiológica do efluente e uma medida segura para a escolha do desinfetante. A desinfecção de água poluída é apenas uma parte do tratamento de esgoto e não é um substituto. Tentativas de clorar despejos não tratados ou mal tratados criarão novos problemas de odor e crescimento posterior de bactérias que degradará posteriormente as águas receptoras (CETESB, 1974).

\subsubsection{Características desejáveis para um desinfetante}

As características desejáveis para um desinfetante, segundo SPELLMAN, (1999) são:

1. Deve agir durante um tempo razoável;

2. Deve agir mesmo em mudanças de $\mathrm{pH}$ e temperatura;

3. Não deve ser tóxico;

4. Não deve adicionar gosto e odores desagradáveis;

5. Deve ser rapidamente disponível;

6. Deve ser seguro e fácil de ser manuseado e aplicado;

7. Deve possibilitar que suas concentrações sejam determinadas com facilidade;

8. Deve ser capaz de manter residual (somente para água);

9. Organismos patogênicos devem ser mais sensíveis à desinfecção que os não patogênicos.

10. Deve ser capaz de ser aplicado continuamente;

11. A quantidade aplicada deve ser suficiente para produzir água potável segura e efluente a ser lançado dentro dos padrões de qualidade do corpo receptor.

A desinfecção não deve ser requerida onde os benefícios significativos não são provados. Os seus benefícios devem ser ponderados com os riscos ambientais e custos. $\mathrm{O}$ cloro deve ser considerado apenas para controle de riscos da saúde pública e não deve ser usado onde a proteção da vida aquática é a consideração principal. Os meios alternativos de desinfecção e descloração devem ser considerados onde os efeitos na saúde pública e na vida aquática conflitam (SPELLMAN, 1999).

O cloro é o desinfetante mais usado no Brasil e no mundo devido a vários fatores de aplicabilidade e eficiência inerentes de agente químico. No entanto, já é amplamente discutida 
a possibilidade desse desinfetante gerar subprodutos que podem ser deletérios tanto a biota aquática quanto ao ser humano. Baseado nesses fatores negativos da aplicação do cloro no tratamento de esgoto, seguem abaixo alguns pontos pertinentes para se avaliar o emprego de outros desinfetantes que não seja o cloro.

Critérios usados para selecionar oxidantes e/ ou técnicas desinfetantes (WATER, 2007):

\begin{tabular}{cl}
\hline \multirow{2}{*}{ Efetividade } & $\begin{array}{l}\text { Possibilidade de alcançar níveis altos de tratamento } \\
\text { Amplo espectro de ação, reações químicas e taxa de inativação } \\
\text { Confiabilidade versus potenciais variações na qualidade da água }\end{array}$ \\
\hline $\begin{array}{c}\text { Possíveis efeitos } \\
\text { negativos }\end{array}$ & $\begin{array}{l}\text { Indução a toxicidade } \\
\text { Formação de subprodutos }\end{array}$ \\
\hline Custo & $\begin{array}{l}\text { Capital investido } \\
\text { Processo operacional e manutenção de equipamentos } \\
\text { Custos associados com pré-tratamentos específicos }\end{array}$ \\
\hline Projeto de & $\begin{array}{l}\text { Capacidade de prever resultados } \\
\text { Adequação para potenciais variações na qualidade da água } \\
\text { Requerimento de testes pilotos }\end{array}$ \\
\hline Condições & $\begin{array}{l}\text { Reagentes para serem transportados e estocados ou produzidos no local } \\
\text { Facilidades de uso e monitoramento } \\
\text { operacionais }\end{array}$ \\
\hline
\end{tabular}

Vale salientar nesse momento, que a desinfecção pode ocorrer através de duas fases, uma chamada de desinfecção primária, que é aquela que o tratamento de água e esgoto tem como objetivo alcançar, ou seja, atingir o CT necessário para a inativação microbiana, e a desinfecção secundária, que é aquela que visa manter desinfetante residual ao longo do sistema de distribuição, ação necessária quando o objeto do tratamento é a água. $\mathrm{Na}$ desinfecção sequencial o desinfetante secundário tem a propriedade de poder causar efeito sinergístico ou ainda melhorar a qualidade do efluente final antes de ser lançado num corpo receptor.

Deve se ter em mente que não importa o fator ou fatores considerados para se decidir qual desinfetante alternativo usar; a consideração principal será que o desinfetante requerido deve ser avaliado caso a caso com consideração do uso benéfico e critérios (SPELLMAN, 1999).

$\mathrm{Na}$ Tabela 3.3 está apresentada uma matriz para determinar a aplicabilidade de técnicas alternativas de desinfecção e auxiliar na escolha de desinfetantes. Para delimitar a discussão desse trabalho, os desinfetantes detalhados foram aqueles usados na presente dissertação. 
Tabela 3.3: Algumas características dos desinfetantes usados no presente trabalho

\begin{tabular}{|c|c|c|c|}
\hline Consideração & $\mathrm{NaOCl}$ & $\mathrm{O}_{3}$ & UV \\
\hline $\begin{array}{l}\text { Porte da estação de } \\
\text { tratamento }\end{array}$ & Todos os tamanhos & $\begin{array}{l}\text { Médio para } \\
\text { grande }\end{array}$ & Pequeno a médio \\
\hline $\begin{array}{l}\text { Aplicação nos níveis de } \\
\text { tratamento }\end{array}$ & Todos os níveis & Secundário & Secundário \\
\hline $\begin{array}{c}\text { Confiabilidade do } \\
\text { equipamento }\end{array}$ & Boa & Boa & Boa \\
\hline Controle do processo & Bem desenvolvida & $\begin{array}{c}\text { Em } \\
\text { desenvolvimento }\end{array}$ & Em desenvolvimento \\
\hline $\begin{array}{c}\text { Complexidade do } \\
\text { processo }\end{array}$ & Simples para moderado & Complexo & $\begin{array}{c}\text { Simples para } \\
\text { moderado }\end{array}$ \\
\hline Segurança & Sim, substancial & Não, moderado & Não, mínimo \\
\hline Bactericida & Bom & Bom & Bom \\
\hline Virucida & Pobre & Bom & Bom \\
\hline Toxicidade aos peixes & Tóxico & Não esperado & Não tóxico \\
\hline Subprodutos perigosos & $\operatorname{Sim}$ & Não esperado & Não \\
\hline Residual persistente & Longo & Não & Não \\
\hline $\begin{array}{l}\text { Contribuição para } \\
\text { geração de oxigênio } \\
\text { dissolvido }\end{array}$ & Não & Sim & Não \\
\hline Tempo de contato & Longo & Moderado & Pequeno \\
\hline Reação com amônia & Sim & $\begin{array}{l}\text { Sim (em pH } \\
\text { elevado) }\end{array}$ & Não \\
\hline Remoção de cor & Moderado & Sim & Não \\
\hline $\begin{array}{l}\text { Aumento de sólidos } \\
\text { dissolvidos }\end{array}$ & Sim & Não & Não \\
\hline Dependência do $\mathrm{pH}$ & $\operatorname{Sim}$ & $\begin{array}{l}\text { Sim (em pH } \\
\text { elevado) }\end{array}$ & Não \\
\hline Corrosividade & Sim & Sim & Não \\
\hline
\end{tabular}

Fonte: SPELLMAN, 1999.

A presença de matéria orgânica pode reduzir, significantemente, a eficácia de um agente desinfetante através da competição na ação oxidante ou promovendo a proteção do germe. O acréscimo de matéria orgânica a uma mistura desinfetante-microrganismo pode resultar em (Pelczar et al., 1980):

1. Combinação do desinfetante com a matéria orgânica, resultando na formação de produtos não microbicidas; 
2. Combinação do desinfetante com a matéria orgânica para formar um precipitado, o que afasta o desinfetante de uma possível combinação com os microrganismos;

3. Acúmulo de matéria orgânica na superfície da célula microbiana, formando um agregado que impede o contato com o desinfetante, necessitando dessa forma, de altas doses de desinfetante para atingir o alvo.

\subsection{Desinfetantes}

A desinfecção clássica é aquela que é promovida aplicando-se apenas um desinfetante. O cloro, por muitos anos e ainda nos dias atuais, tem sido o agente mais empregado nas estações de tratamento de esgotos e possui uma certa hegemonia no tratamento de água, devido ao seu caráter de desinfecção secundário ( para manutenção de residual na rede de distribuição de água) ser amplamente reconhecido, ainda que haja o risco da formação de subprodutos clorados.

No tratamento de esgoto, não é desejável a manutenção de residual de desinfetante quando o efluente será despejado no corpo receptor, e tem-se buscado alcançar maior eficiência na remoção de microrganismos utilizando-se menores doses de desinfetantes.

A desinfecção sequencial e combinada, que utiliza mais de um desinfetante sequencialmente e simultaneamente, respectivamente, tem se mostrado eficiente para reduzir a formação de subprodutos de desinfecção e adicionar efeito à desinfecção individual devido ao efeito sinergístico produzido tanto pela aplicação simultânea quanto sequencial.

Efeito sinergístico em processos de desinfecção sequêncial ou combinados são benéficos por conta da possível redução da dose de desinfetante a ser utilizada e do tempo de contato requerido para alcançar o mesmo nível de inativação, reduzindo assim custos operacionais, podendo diminuir a formação de subprodutos de desinfecção (CHO et al., 2006).

A aplicação sequêncial de certos desinfetantes tem mostrado um maior nível de inativação que a soma de inativação quando cada desinfetante é aplicado separadamente. Esta inativação melhorada é geralmente referida como sinergismo em processos de desinfecção sequêncial (CHO et al., 2006).

Processos avançados de oxidação designam a aplicação de processos conjugados destinados ao tratamento de águas de abastecimento e, mais recentemente, residuárias, nos quais sistemas compostos de dois ou mais agentes químicos ou físicos são introduzidos sequencial ou simultaneamente em operações unitárias específicas para promover a oxidação de matéria orgânica e inativação de indicadores patogênicos (MONACO, 2006). 
Segundo USEPA (1999), o número de microrganismos sobreviventes às duas etapas de desinfecção, em comparação a uma única etapa e sob condições semelhantes de dosagem e tempo de contato, é substancialmente inferior.

MONACO (2006) afirma que a utilização de sistemas combinados de desinfecção apresenta potencial efetivo de aplicação em unidades reais de tratamento.

\subsubsection{Cloro}

\subsubsection{História do cloro}

O cloro foi descoberto ocasionalmente em 1774 por Carl Wilhelm Scheele, quando fazia experiências com ácido muriático e dióxido de manganês. Dessa mistura, desprendeu um gás amarelo-esverdeado que foi chamado pelo seu descobridor de ácido muriático "deflogisticado" ou ácido muriático oxigenado. Essa nomenclatura manteve-se até 1810, quando Sir Humphrey Davy conseguiu provar que o gás misterioso de Scheele era na realidade um elemento químico, e foi justamente devido a sua característica mais evidente, isto é, a sua cor amarelo-esverdeada, que recebeu então o nome de Chloro (CETESB, 1974).

Durante muito tempo, conforme relatos de manuais escritos na época, sua preparação era difícil e seu transporte e manipulação impossíveis (CETESB, 1974).

Faraday, em 1882, conseguiu produzi-lo na forma de óleo. O cloro líquido foi produzido pela primeira vez na Alemanha, em 1888, no entanto, passou a ser comercializado apenas em 1909 nos EUA (CETESB, 1974).

Até 1930, o cloro era considerado um simples subproduto da fabricação eletrolítica da soda cáustica. Foi somente depois da segunda Guerra Mundial e do desenvolvimento da indústria química que o seu consumo aumentou (CETESB, 1974).

$\mathrm{Na}$ vida moderna, o cloro tem um papel muito importante na produção de fibras sintéticas, borrachas sintéticas, materiais plásticos, produtos sanitários, solventes orgânicos, inseticidas, produtos farmacêuticos e veterinários, tendo grande importância na desinfecção de água de abastecimento e na depuração de águas residuárias (CETESB, 1974).

O uso do cloro tem sido associado há muito tempo a um meio de controlar doenças no homem. Até o século 19, persistia a idéia de que as doenças eram espalhadas pelo odor e que o controle do odor acabaria com a sua disseminação. Portanto, não é de se causar surpresa saber que o cloro foi utilizado como desodorante antes que o seu valor germicida tivesse sido reconhecido. As bactérias foram descobertas aproximadamente em 1680 e por volta de 1880 
pesquisas revelaram que esses microrganismos - agora chamados de patógenos - causam doenças específicas (WHITE, 1972).

A aplicação do cloro no saneamento é ampla, podendo-se destacar (WATER, 2007):

* É usado em águas potável e de piscina;

Em circuito de resfriamento (cooling);

Em tratamento terciário de esgoto;

* Usado principalmente para desinfetar água, mas também para controlar o desenvolvimento de vários organismos (algas, moluscos, mexilhões);

* Pode também oxidar compostos responsáveis por gosto e odor;

* Oxidar ferro e manganês;

* Remover cor;

Melhorar coagulação.

\subsubsection{Aplicação do cloro no tratamento de efluentes}

O Cloro puro $\left(\mathrm{Cl}_{2}\right)$ dissocia-se quando adicionado na água, segundo a reação (3.1):

$$
\mathrm{Cl}_{2}+\mathrm{H}_{2} \mathrm{O} \rightleftharpoons \mathrm{HClO}+\mathrm{H}^{+}+\mathrm{Cl}^{-}
$$

Essa reação se completa em pH acima de 4,0, onde todo cloro é transformado em ácido hipocloroso e ácido clorídrico. Apenas o primeiro tem ação desinfetante, pois ele destrói a enzima essencial para o metabolismo dos microrganismos na oxidação da glicose (PIVELI \& KATO, 2006).

O ácido hipocloroso também se dissocia quando adicionado à água, produzindo o íon hipoclorito que tem efeito desinfetante inferior quando comparado à forma não dissociada (equação 3.2).

$\mathrm{HOCl} \rightleftharpoons \mathrm{H}^{+}+\mathrm{OCl}^{-}$

Este equilíbrio é dependente do $\mathrm{pH}$. Para valores de $\mathrm{pH}$ acima de 7 prevalece o íon hipoclorito e abaixo de 7,0 o ácido hipocloroso representado na Figura 3.1. 


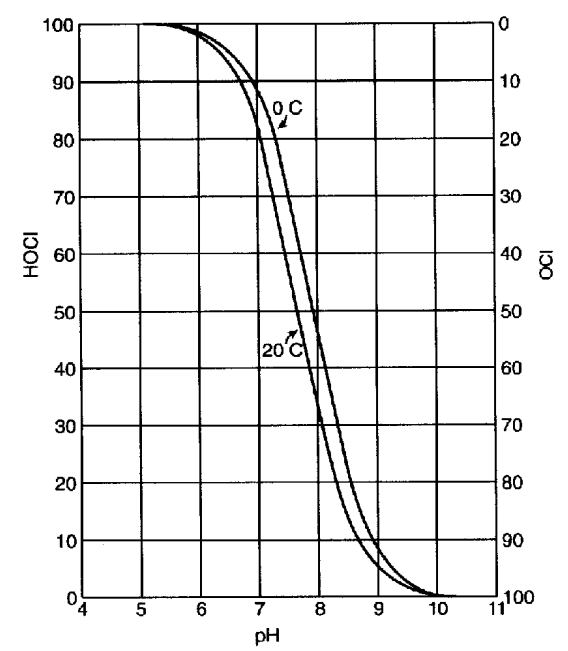

Figura 3.1: Distribuição do ácido hipocloroso e do íon hipoclorito em água, em diferentes valores de $\mathrm{pH}$ e temperatura.

O ponto importante a se considerar é que o ácido hipocloroso $(\mathrm{HClO})$ é um agente desinfetante poderoso enquanto que o íon hipoclorito $\left(\mathrm{OCl}^{-}\right)$tem pouca ou nenhuma atividade desinfetante. $\mathrm{O}$ controle do $\mathrm{pH}$ de efluentes de esgoto numa faixa de 6,5 a 7,5 pode garantir o alto rendimento do ácido hipocloroso. O cloro reage com um grande número de substâncias na forma de ácido hipocloroso e/ou íon hipoclorito dependendo do $\mathrm{pH}$ do meio.

Tratar o esgoto que contém resíduos domésticos e industriais é complexo devido à natureza de sua composição química. A maioria dos efluentes de esgoto contém quantidades apreciáveis de amônia. A cloração dessas águas poluídas resulta na formação do ácido hipocloroso $(\mathrm{HOCl})$ que rapidamente se converte em compostos de cloramina, como demonstrado nas reações (3.3) a (3.5):

$$
\begin{aligned}
& \mathrm{NH}_{3}+\mathrm{HOCl} \rightarrow \mathrm{NH}_{2} \mathrm{Cl}+\mathrm{H}_{2} \mathrm{O} \\
& \mathrm{NH}_{2} \mathrm{Cl}+\mathrm{HOCl} \rightarrow \mathrm{NHCl}_{2}+\mathrm{H}_{2} \mathrm{O} \\
& \mathrm{NHCl}_{2}+\mathrm{HOCL} \leftrightarrow \mathrm{NHCl}_{3}+\mathrm{H}_{2} \mathrm{O}
\end{aligned}
$$

Além de combinar com a amônia, o ácido hipocloroso reage com aminoácidos, materiais protéicos e outras substâncias orgânicas para produzir compostos de pequeno ou nenhum poder desinfetante. Reação com sulfitos, sulfetos, nitritos e íons ferrosos ou manganosos também dissiparão a ação desinfetante formando compostos com nenhum efeito germicida (CETESB, 1974). 
A cloração pode criar compostos com poluentes inorgânicos considerados como deletérios. A presença de subprodutos em água clorada depende do $\mathrm{pH}$ do meio, da quantidade de cloro usado e do tempo de reação (WATER, 2007).

Ação do cloro em compostos inorgânicos esta exemplificada nas seguintes reações, comuns no tratamento de água para abastecimento e no tratamento de águas residuárias:

Precipitação do Ferro: $2 \mathrm{Fe}\left(\mathrm{HCO}_{3}\right)_{2}+\mathrm{Cl}_{2}+\mathrm{Ca}\left(\mathrm{HCO}_{3}\right)_{2} \rightarrow 2 \mathrm{Fe}(\mathrm{OH})_{3}+\mathrm{CaCl}_{2}+6 \mathrm{CO}_{2}$

Precipitação do manganês: $\mathrm{Mn}^{+2}+\mathrm{Cl}_{2}+4 \mathrm{OH}^{-} \rightarrow \mathrm{MnO}_{2}+2 \mathrm{Cl}^{-}+2 \mathrm{H}_{2} \mathrm{O}$

Oxidação do sulfeto: $\mathrm{H}_{2} \mathrm{~S}+\mathrm{Cl}_{2} \rightarrow \mathrm{S}+2 \mathrm{HCl}$

$$
\mathrm{H}_{2} \mathrm{~S}+4 \mathrm{Cl}_{2}+4 \mathrm{H}_{2} \mathrm{O} \rightarrow \mathrm{H}_{2} \mathrm{SO}_{4}+8 \mathrm{HCl}
$$

Dependente do $\mathrm{pH}$ da reação

Oxidação do nitrito: $\mathrm{NO}_{2}{ }^{-}+\mathrm{HOCl} \rightarrow \mathrm{NO}_{3}{ }^{-}+\mathrm{HCl}$

O cloro tem uma ação seletiva em poluentes orgânicos. A sua reatividade envolve sítios especiais de ataque (reduzidos, insaturados, nucleófilos) e causam mudanças estruturais acompanhados da formação de compostos mais oxidados (Tabela 3.4). No entanto a cloração da água com o objetivo de produção de água para abastecimento pode criar compostos que são indesejáveis pelo ponto de vista de odor e sabor (aldeídos, clorofenóis), tóxicos (trialometanos) e/ou potencialmente carcinogênicos (organoclorados). Assim como no caso de compostos inorgânicos, a presença destes compostos secundários dependerá do $\mathrm{pH}$ do meio, da quantidade de cloro usado e do tempo de reação (WATER, 2007).

Tabela 3.4: Compostos orgânicos e seus produtos quando clorados (WATER, 2007).

\begin{tabular}{l|l}
\hline \multicolumn{1}{c|}{ Compostos orgânicos } & \multicolumn{1}{c}{ Produtos da cloração } \\
\hline Alcoóis & Aldeídos, ácidos, cetonas \\
\hline Aldeídos e cetonas & $\begin{array}{l}\text { Acetonas cloradas, clorofórmio, ácidos } \\
\text { clorados }\end{array}$ \\
\hline Tiolatos & Bissulfetos \\
\hline Sulfetos & Óxidos de enxofre \\
\hline Amina & Cloramina \\
\hline Aminoácido & Aminas, nitrilas, carboxilas \\
\hline Aromáticos & Aromáticos clorados \\
\hline
\end{tabular}

Como as características do esgoto variam de hora a hora, de estação a estação, de dia e noite, a influência da desinfecção de uma dada dose de cloro consequentemente variará (CETESB,1974).

O lançamento de esgoto de estações de tratamento de esgoto mal operadas pode adicionar cargas significativas de nutrientes para bactérias ao corpo receptor. Altos valores de 
DBO residual, podem criar outro problema bacteriológico à jusante se esses efluentes parcialmente tratados forem clorados (CETESB, 1974).

Como a cloração raramente elimina todos os microrganismos presentes no efluente, os organismos sobreviventes, protegidos do contato com o cloro pelo material suspenso, servem de inóculo quando os agregados se desintegram, havendo assim, a liberação de células viáveis que poderão se nutrir da matéria orgânica que foi parcialmente tratada em sistemas mal operados (CETESB, 1974).

A maioria dos problemas de multiplicação bacteriana ocorrem num período de 1 a 2 dias de percurso da entrada do efluente clorado, período este, durante o qual os microrganismos podem se recuperar dos efeitos da cloração e se multiplicar no meio de nutrientes atingindo elevado número. $\mathrm{O}$ crescimento posterior nem sempre ocorre quando o tratamento secundário do esgoto produz uma excelente redução de nutrientes (CETESB, 1974).

Depois de clorado, o efluente deve ser desclorado para ser lançado no corpo receptor. A descloração é feita com a adição de substâncias redutoras. Normalmente são utilizados os compostos de enxofre: dióxido de enxofre, sulfito de sódio e metabissulfito de sódio.

A cinética de descloração com compostos sulfurosos é muito rápida e devido à rapidez das reações, a mistura é o parâmetro mais importante a ser considerado com compostos de enxofre usados para descloração (JOHNSON, 1975).

As vantagens do cloro na desinfecção de esgotos estão relacionados a seguir (WERF, 1995):

1. Tecnologia bem estabelecida;

2. É um desinfetante efetivo;

3. Relativamente barato;

4. Cloro residual pode ser mantido, como é desejado para água de abastecimento, garantindo manutenção do efeito germicida em longas linhas de distribuição de água potável.

Segundo WERF (1995), algumas desvantagens do uso do cloro em desinfecção de esgotos são:

1. A toxicidade residual do efluente tratado deve ser reduzida por descloração;

2. Formação de trialometanos e outros hidrocarbonetos clorados;

3. O uso do cloro em baixas concentrações usadas para inativação de coliformes pode não ser suficiente para ter inativação eficiente de alguns vírus, esporos e cistos; 
4. Ocorre aumento no nível total de sólidos dissolvidos no efluente tratado;

5. Aumenta a concentração de cloreto no efluente;

6. Geração de ácido, decorrente da redução do pH se a alcalinidade for insuficiente.

\subsubsection{Mecanismos de desinfecção com cloro}

Algumas hipóteses têm sido propostas para explicar o efeito germicida do cloro e de seus compostos correlatos. Acredita-se que assim que o cloro é difundido na célula, o protoplasma celular é oxidado. No entanto, o mecanismo de oxidação sozinho não pode ser considerado um efeito germicida. É sabido que o cloro precipita proteína e acredita-se que ele pode alterar o arranjo químico de enzimas e em muitos casos inativá-las diretamente. Acredita-se também que a presença de compostos clorados destrói a permeabilidade seletiva da parede celular e permite a difusão dos solutos vitais e nutrientes para fora da célula (WERF, 1995).

Outro mecanismo proposto é que compostos de cloro hidrolisam os polissacarídeos da parede celular causando o enfraquecimento da mesma. Se a concentração dos solutos celulares é menor que a do meio ao entorno, o soluto irá fluir para fora da célula, tornando-a desidratada e finalmente, o protoplasma celular colapsará. No entanto, ainda que todos os mecanismos anteriormente descritos possam ocorrer, o mecanismo predominante dependerá do microrganismo em questão, do composto clorado usado e das características do esgoto (WERF, 1995).

\subsubsection{Ozônio}

\subsubsection{História}

Em 1785, Van Marum notou odor durante uma descarga elétrica, mas em 1840, Schonbein mostrou que esse odor ocorria devido a um gás particular que ele nomeou de Ozone (que tem origem do grego Ozein). Em 1857, Siemens construiu o primeiro aparato para produzir ozônio por descargas elétricas e Soret estabeleceu a sua fórmula em 1867 (JOHNSON, 1975).

Em 1886, pela primeira vez, De Meritens desinfetou água com ozônio. E a primeira instalação permanente foi em Oudshoorn na Holanda, onde água do rio Reno, após sedimentação e filtração, foi desinfetada com ozônio (JOHNSON, 1975).

$\mathrm{Na}$ década de 70, já havia mais de 1000 instalações em 20 diferentes países, incluindo França, Alemanha, Suíça, Noruega, Holanda, Rússia, Canadá e México (JOHNSON, 1975). 
O ozônio é geralmente referido como uma forma alotrópica do oxigênio. É um gás azul pálido com odor pungente e distinto, que se torna perceptível pelo olfato humano em concentrações inferiores a 1 ppm no ar. A cor, por sua vez, não é perceptível em concentrações normalmente produzidas e usadas. O ozônio é aproximadamente 10 vezes mais solúvel na água que o oxigênio, mas a quantidade que pode ser dissolvida sob condições operacionais é baixa (JOHNSON, 1975). A solubilidade do ozônio diminui com o aumento da temperatura. Algumas propriedades do ozônio estão descritas na Tabela 3.5.

Tabela 3.5: Algumas propriedades do ozônio.

\begin{tabular}{|l|c|}
\hline Massa Molar & 48 \\
\hline Densidade a $0^{\circ} \mathrm{C}$ & $2,14 \mathrm{~g} / \mathrm{L}$ \\
\hline $\mathrm{P}_{\text {ebulição }}$ & $-111,9^{\circ} \mathrm{C}$ \\
\hline $\mathrm{P}_{\text {fusão }}$ & $-251^{\circ} \mathrm{C}$ \\
\hline
\end{tabular}

A estabilidade do ozônio é facilmente afetada pelo $\mathrm{pH}$, luz ultravioleta, concentração de ozônio e concentração de sequestradores (scavengers) de radicais livres (LANGLAIS, 1991). Devido à instabilidade da sua estrutura molecular, principalmente devido à deficiência eletrônica das suas estruturas de ressonância, o ozônio na fase líquida ou gasosa pode produzir uma série de reações instantâneas quando em contato com substâncias oxidáveis. Devido a sua instabilidade, o ozônio deve ser gerado no local de uso, e por ser extremamente corrosivo, os materiais para a construção de sistemas de ozonização devem ser escolhidos considerando a compatibilidade com o ozônio (JOHNSON, 1975; WHITE, 1972).

É um gás que está presente naturalmente na estratosfera como o resultado da ação da radiação UV emitida pelo sol nas moléculas de oxigênio. Provê proteção contra a radiação UV danosa. (WATER, 2007).

\subsubsection{Usos do ozônio}

O ozônio é o agente oxidante mais forte que pode ser usado em escala prática para o tratamento de água e esgoto (JOHNSON, 1975).

Devido a sua natureza fortemente oxidante, o ozônio pode reagir e promover (LANGLAIS, 1991):

1. Controle de gosto e odor;

2. Desinfecção;

3. Remoção de cor;

4. Remoção de DQO e DBO; 
5. Remoção de sólidos por arraste promovido pelas bolhas na coluna de contato (JOHNSON, 1975).

6. Oxidação de ferro e manganês;

7. Saturar o efluente com oxigênio dissolvido (JOHNSON, 1975).

8. Tem efeito de coagulação;

9. Controle de turbidez;

10. Oxidação de compostos fenólicos;

11. Oxidação de pesticidas;

12. Controle de crescimento de algas;

13. Controle de subprodutos de desinfecção com compostos clorados;

14. Estabilização biológica.

A ozonização reduz a absorção de radiação ultravioleta, podendo assim, trazer vantagens para aplicação de reuso (XU et al., 2002).

A reação do ozônio com metais de transição, tais como, ferro, chumbo e prata, leva esses elementos a formas com estado de oxidação menos solúveis em meio aquoso, podendo ser removidos por filtração (MONACO, 2006).

No entanto, a presença de matéria orgânica em suspensão pode competir com a desinfecção na ação do ozônio, pois a cinética de reação da matéria orgânica com o ozônio, em muitos casos, é mais favorável (MONACO, 2006).

\subsubsection{Geração do Ozônio}

A geração do ozônio no presente trabalho segue o processo denominado descarga corona. O método baseia-se na conversão de moléculas de oxigênio em ozônio, através da passagem de ar atmosférico pressurizado entre dois eletrodos nos quais é aplicada uma tensão elétrica.

Os elétrons gerados na descarga corona possuem energia interna suficiente para provocar a dissociação de moléculas de oxigênio em seus átomos constituintes, segundo a reação 3.6.

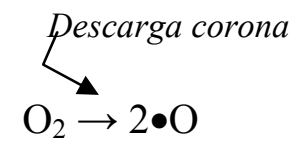

Os átomos de oxigênio liberados, altamente instáveis, reagem com novas moléculas de oxigênio para formar ozônio gasoso (equação 3.7). 
$\bullet \mathrm{O}+\mathrm{O}_{2} \rightarrow \mathrm{O}_{3}$

Além da descarga corona, existem outros métodos de geração de ozônio, como o método fotoquímico que utiliza radiação UV, o método eletrolítico e o método radioquímico com o ${ }^{137} \mathrm{Cs}$, o ${ }^{60} \mathrm{Co}$ ou o ${ }^{90} \mathrm{Sr}$ como fonte de radiação (COSTA, 2003).

O contato entre as fases gasosa e líquida (efluente) do ozônio ocorre na câmara de ozonização, onde são promovidas as reações de desinfecção e oxidação-redução.

Embora altamente solúvel em água, a concentração de ozônio na fase gasosa está limitada a sua baixa pressão parcial na saída do equipamento gerador (2 a $3 \%$ em peso) (MONACO, 2006).

A diminuição da temperatura e do $\mathrm{pH}$ eleva a solubilidade do gás, favorecendo as reações de oxidação e desinfecção pelo aumento da concentração de ozônio disponível (WEF, 1996), (MONACO, 2006).

\subsubsection{Mecanismos de Decomposição do Ozônio}

Em solução aquosa, o ozônio pode agir com vários compostos de duas maneiras (LANGLAIS, 1991):

- via oxidação direta;

- via ação indireta.

O mecanismo predominante dependerá das características físico-químicas do efluente ozonizado.

$\mathrm{Na}$ via direta, a oxidação envolve reações seletivas, que atuam diretamente em grupos funcionais específicos presentes no material alvo, como compostos orgânicos e estruturas bioquímicas. Essas reações são mais efetivas na inativação de microrganismos quando comparadas ao processo indireto.

$\mathrm{Na}$ via indireta, surgem as reações adicionais envolvendo oxidantes instáveis que reagem prontamente com as várias substâncias orgânicas e inorgânicas encontradas no efluente (STAEHELIN \& HOIGNÉ, $1985^{5}$ ). Essas reações podem ocorrer em três fases: iniciação, propagação e inibição.

\footnotetext{
${ }^{5}$ STAEHELIN. J. \& HOIGNÉ. J.; 1985. Decomposition of Ozone in Water in the Presence of Organic Soluter Acting as Promoters and Inibitors of Radical Chain Reations. Environment Science Tecnology, 19 (12). 12061213. Citado por Bilotta, P. (2006). Inativação de Indicadores Patogênicos em Sistemas Combinados de Tratamento e Pré-Desinfecção de Esgoto Sanitário. Tese (Doutorado). Escola de Engenharia de São Carlos, Universidade de São Paulo.
} 
A iniciação é a fase determinante. Nela, iniciadores de reação, como os íons hidroxila $\left(\mathrm{OH}^{-}\right)$, convertem o ozônio em ânions superóxido $\left(\bullet \mathrm{O}_{2}^{-}\right)$e radicais hidroperoxil $\left(\bullet \mathrm{HO}_{2}\right)$, que por sua vez, formam os íons radicalares $\left(\bullet \mathrm{O}_{3}^{-}\right)$, conforme as equações (3.8) e (3.9):

$\mathrm{O}_{3}+\mathrm{OH}^{-} \rightarrow\left[\bullet \mathrm{O}_{2}^{-} \leftrightarrow \bullet \mathrm{HO}_{2}\right]$

$\cdot \mathrm{O}_{2}^{-}+\mathrm{O}_{3} \rightarrow \cdot \mathrm{O}_{3}^{-}+\mathrm{O}_{2}$

Na sequência são formados os radicais livres, principais responsáveis pela oxidação da matéria orgânica e inorgânica devido a sua elevada instabilidade, e em particular a hidroxila radicalar $(\bullet \mathrm{OH})(\mathrm{WEF}, 1996)$, conforme apresentado na reação (3.10):

$\bullet \mathrm{O}_{3}^{-}+\mathrm{H}^{+} \rightarrow \bullet \mathrm{HO}_{3}^{-} \rightarrow \bullet \mathrm{OH}+\mathrm{O}_{2}$

A etapa denominada inibição tem início quando os íons superóxido são consumidos e não são regenerados. Vários compostos orgânicos e inorgânicos podem agir como inibidores como, por exemplo, o carbonato $\left(\mathrm{CO}_{3}^{2-}\right)$ e bicarbonato $\left(\mathrm{HCO}_{3}^{-}\right)$dissolvidos (LANGLAIS, 1991).

Em elevadas concentrações, esses compostos podem interromper totalmente a reação em cadeia, reduzindo consideravelmente a capacidade de oxidação do ozônio (LANGLAIS, 1991).

Por outro lado, em unidades de tratamento destinadas à desinfecção de esgoto sanitário, a presença de espécies como $\mathrm{HCO}_{3}^{-}$e $\mathrm{CO}_{3}^{2-}$ estimulam a decomposição do ozônio pelo mecanismo direto e, portanto, favorecem as reações de inativação (GLAZE, $1987^{6}$ apud MONACO, 2006), (STAEHELIN \& HOIGNÉ $1985^{7}$ apud MONACO, 2006). Na

Tabela 3.6 estão apontados alguns iniciadores, promotores e inibidores do ozônio.

$\mathrm{Na}$ fase inibidora, os radicais hidroxilas são consumidos pela transferência de elétrons (equação 3.11):

\footnotetext{
${ }^{6}$ GLAZE. W. H. 1987. Drinking Water Treatment With Ozone. Environment Science Tecnology, 21(3): 224229.

7 STAEHELIN. J. \& HOIGNÉ. J.; 1985. Decomposition of Ozone in Water in the Presence of Organic Soluter Acting as Promoters and Inibitors of Radical Chain Reations. Enviroment Science Tecnology, 19 (12). 12061213.
} 


$$
\mathrm{HCO}_{3}^{-}+\bullet \mathrm{OH} \rightarrow \mathrm{OH}^{-}+\mathrm{HCO}_{3}
$$

Tabela 3.6: Iniciadores, promotores e inibidores do ozônio

\begin{tabular}{ccc}
\hline Iniciadores & Promotores & Inibidores \\
\hline $\mathrm{OH}^{-}$ & $\mathrm{R}_{2}-\mathrm{CH}-\mathrm{OH}$ & $\mathrm{CH}_{3}-\mathrm{CO}-\mathrm{O}^{-}$ \\
$\mathrm{H}_{2} \mathrm{O}_{2} / \mathrm{HO}_{2}^{-}$ & aril- $(\mathrm{R})$ & alquil- $(\mathrm{R})$ \\
húmicos & Húmicos & húmicos \\
$\mathrm{Fe}^{2+}$ & $\mathrm{O}_{3}$ & $\mathrm{HCO}_{3}^{-} / \mathrm{CO}_{3}^{2-}$ \\
Radiação UV & \multicolumn{3}{l}{} \\
Fonte: AWWA (1991) ${ }^{8}$, apud MONACO, 2006.
\end{tabular}

Conforme as diferentes maneiras que o ozônio reage com compostos orgânicos pode se estabelecer três categorias de compostos (WATER, 2007):

-compostos aromáticos e alifáticos insaturados são facilmente oxidados; -compostos saturados e insaturados oxigenados ou halogenados são ligeiramente degradáveis; -compostos que contenham ligações $\mathrm{C}-\mathrm{H}$, como o tetraclorometano ou pentaclorofenol são totalmente inertes.

Compostos suscetíveis à reação com ozônio são principalmente aqueles que contêm sítios nucleofílicos como oxigênio, nitrogênio, enxofre, fósforo e carvão ativado (LANGLAIS, 1991).

No processo de degradação, muitos produtos de moléculas clivadas são formados. Esses são mais oxidáveis, mais polares, possuem menores pesos moleculares e, muitas vezes, são mais biodegradáveis que seus precursores (LANGLAIS, 1991).

No caso de substâncias poucamente reativas (aquelas que não apresentam sítios nucleofílicos e possivelmente com estruturas muito simétricas) deve ser necessário combinar ozônio com outros agentes, tais como UV e $\mathrm{H}_{2} \mathrm{O}_{2}$, para eliminar compostos orgânicos (LANGLAIS, 1991).

O desempenho global da ozonização depende da eficiência da geração e transferência do gás para o efluente. A concentração de ozônio deve ser estimada a atender a demanda das reações rápidas de oxidação com as espécies orgânicas e inorgânicas, bem como, promover as reações com as várias espécies de microrganismos patogênicos ali presentes (MONACO, 2006).

\footnotetext{
${ }^{8}$ AWWA (1991). Ozone in Water Treatment. American Water Works Association. Michigan.
} 
Algumas das reações do ozônio com a matéria inorgânica, que normalmente ocorrem no tratamento de águas, estão apresentados a seguir:

Precipitação com ferro: $2 \mathrm{Fe}^{+2}+\mathrm{O}_{3}+5 \mathrm{H}_{2} \mathrm{O} \rightarrow 2 \mathrm{Fe}(\mathrm{OH})_{3}+\mathrm{O}_{2}+4 \mathrm{H}^{+}$

Precipitação do manganês: $\mathrm{Mn}^{+2}+\mathrm{O}_{3}+\mathrm{H}_{2} \mathrm{O} \rightarrow \mathrm{MnO}_{2}+2 \mathrm{H}^{+}+\mathrm{O}_{2} \mathrm{O}$ manganês reage mais lentamente com ozônio que com ferro. A taxa de eliminação é significativamente menor quando a água contém substâncias orgânicas. Adicionalmente, a aplicação de excesso de ozônio promove a formação de permanganato e o desenvolvimento de coloração rosa (WATER, 2007)

Oxidação do sulfeto: $\mathrm{S}^{2-}+4 \mathrm{O}_{3} \rightarrow \mathrm{SO}_{4}{ }^{2-}+2 \mathrm{O}_{2}$

Oxidação do nitrito: $\mathrm{NO}_{2}^{-}+\mathrm{O}_{3} \rightarrow \mathrm{NO}_{3}^{-}+\mathrm{O}_{2}$

Oxidação de halogenos (teoricamente ozônio pode oxidar todos os halogenos). Na prática, a taxa de reação é virtualmente zero com o cloro, extremamente alto com o iodo e médio com bromo (WATER, 2007).

Algumas das reações do ozônio com a matéria orgânica estão apresentados na Tabela 3.7 .

Tabela 3.7: Reação do ozônio com compostos orgânicos.

\begin{tabular}{l|l}
\hline \multicolumn{1}{c|}{ Compostos orgânicos } & \multicolumn{1}{c}{ Produtos da ozonização } \\
\hline Alcenos & $\begin{array}{l}\text { Ácido, aldeídos saturados, dióxido de } \\
\text { carbono }\end{array}$ \\
\hline Compostos aromáticos & $\begin{array}{l}\text { Fenóis, quinonas, ácidos alifáticos, } \\
\text { dióxido de carbono }\end{array}$ \\
\hline Aminas & $\begin{array}{l}\text { Hidroxilaminas, óxidos, amidas, amônia, } \\
\text { nitrato, ácidos carboxílicos }\end{array}$ \\
\hline Alcoóis & Aldeídos, ácidos carboxílicos, cetonas \\
\hline Aldeídos e cetonas & Ácidos carboxílicos \\
\hline
\end{tabular}

\subsubsection{Inativação de bactérias}

A inativação de bactéria por ozônio pode ser considerada como uma reação de oxidação. A oxidação é causada pelo alto potencial de oxidação-redução do ozônio na água; pela habilidade do ozônio em se difundir em sítios a serem desativados e por espécies químicas como os radicais livres, que são subprodutos reativos do ozônio (LANGLAIS, 1991).

A membrana bacteriana parece ser o primeiro sítio a ser atacado através das glicoproteínas ou glicolipídeos ou através de certos aminoácidos como o triptofano (LANGLAIS, 1991).

O ozônio também prejudica a atividade enzimática da bactéria pela ação em grupos sulfidril de certas enzimas. Pesquisadores notaram que bactérias ozonizadas perderam sua 
habilidade de degradar açucares e de produzir gases (VROCHINSKII, $1963^{9}$ apud LANGLAIS, 1991). A morte bacteriana pode ocorrer devido a mudanças na permeabilidade celular possivelmente seguida de lise celular (MURRAY et al., $1965^{10}$ apud LANGLAIS, 1991).

Assim que atravessa a membrana e a parede celular, o ozônio pode agir no material nuclear, que é um sítio preferencial de oxidação (LANGLAIS, 1991). HAMELIN \& CHUNG (1975) sugerem que o ozônio atua no DNA, alvo considerado mais sensível, e essa ação é comum a encontrada para os agentes que emitem radiação. Esses autores observaram em seu trabalho, que bactérias sobreviventes à radiação UV tiveram o comportamento de serem mais sensíveis quando submetidas à ozonização, que as bactérias parentais.

LANGLAIS (1991) também menciona que os fluidos celulares possuem pH perto do neutro e uma elevada concentração de íons bicarbonatos. Pode haver inibição devido a alguns compostos celulares que impedem a ação do ozônio. Mas se o ozônio residual conseguir atravessar a membrana citoplasmática e o citoplasma, o material genético será rapidamente degradado, sendo que os sítios principais, no material genético, são as bases nitrogenadas guanina e timina.

\subsubsection{Comparação do Ozônio com o Cloro}

A oxidação e a reação de inativação bacteriana sempre ocorrem muito rápido, e isso fez com que Bringman, em 1954, sugerisse que o ozônio reagiria diferentemente do cloro. Ele propôs que o cloro oxidaria certos sistemas enzimáticos seletivamente, enquanto que o ozônio atuaria como agente oxidante geral (LANGLAIS, 1991).

O ozônio não se dissocia na água como o cloro, portanto, não sofre assim com a perda na eficiência da desinfecção. Além disso, ele não reage com a amônia para formar formas menos desinfetantes como as cloraminas. Esse gás é um forte agente oxidante, no entanto, uma alta demanda de ozônio é exercida na redução de matéria orgânica e inorgânica, presentes na água e por ser maior para o ozônio do que para o cloro, essa demanda pode ser esperada, pois o ozônio é um agente oxidante mais forte que o cloro (JOHNSON, 1975).

O ozônio tem certas vantagens sob o cloro na desinfecção de esgotos (SPELLMAN, 1999):

* Ozônio aumenta o oxigênio dissolvido do efluente;

\footnotetext{
${ }^{9}$ VROCHINSSKII, K. K. 1963. Experimental data on Water Decontamination with Ozone. Hyg. Sanit., 28:3.

${ }^{10}$ MURRAY, R.G.E. et al. 1965. The location of the Mucopeptide of Sections of The Cell Wall of Escherichia coli and other Gram-Negative Bactéria. Can. J. Microbiol., 11: 3: 547-560.
} 
* Ozônio não deixa residual;

* Ozônio não tem efeitos indesejáveis sob os organismos aquáticos;

* Ozônio diminui a turbidez e a cor.

O maior benefício da desinfecção com o ozônio é que os compostos orgânicos ozonizados são mais biodegradáveis que os compostos clorados. Entretanto, a maior deficiência desse gás como desinfetante é que, devido ao seu alto poder oxidante, ele é muito instável na água, possuindo apenas um pequeno tempo de vida. Em vista disso, a desinfecção com o ozônio não provê um residual para servir como um indicador de garantia de segurança microbiológica (JOHNSON, 1975).

Assim como o cloro, o ozônio é um gás tóxico e pode causar doenças severas e morte se inalado em quantidade suficiente para isso. A vantagem que o ozônio tem sobre o cloro é que ele é gerado no local de uso eliminando o perigo de transporte. Outro fator de segurança é que o odor do ozônio é detectado em concentração inferior a do nível de risco (SPELLMAN, 1999).

\subsubsection{Radiação UV}

O uso da radiação UV na desinfecção de efluentes secundários de esgoto sanitário surgiu como método alternativo ao cloro por possuir vantagens de não manter residual desinfetante e minimizar a potencialidade de geração de subprodutos prejudiciais à saúde, diminuindo a introdução de produtos danosos ao corpo receptor. Radiação UV aplicado como parte do tratamento de desinfecção é reconhecido por sua mínima produção de subprodutos (WATER, 2007).

OLIVER \& COSGROVE $^{11}$ (1975) apud COLETTI (2003), em escala de laboratório, provou a viabilidade da utilização da radiação ultravioleta como agente desinfetante em efluente secundário de esgoto sanitário.

Antes disso, a radiação ultravioleta já era aplicada, e apenas na desinfecção de água de abastecimento, pois se acreditava que a matéria em suspensão, cor e turbidez, presentes em maiores quantidades, absorveriam grande parte da radiação incidente, prejudicando a desinfecção (COLETTI, 2003).

Pesquisas realizadas no Departamento de Hidráulica e Saneamento da Escola de Engenharia de São Carlos, tais como CAMPOS \& PIZZIRANI (1977), SAMPAIO (1985), DANIEL (1989), DANIEL (1993), SOUZA (2000), BILOTTA (2000), DIAS (2001),

\footnotetext{
${ }^{11}$ OLIVER, B. G. \& COSGROVE, E.G. (1975). The disinfection of sewage treatment plant effluents using ultraviolet light. Canadian Journal of Chemical Engineering, v. 53, n. 4, p. 170-174, abril.
} 
COLETTI (2003), MONACO (2006) e também pesquisas realizadas em outras entidades no Brasil e no mundo confirmam a viabilidade do emprego da radiação UV na desinfecção de esgoto sanitário.

\subsubsection{Mecanismos de desinfecção com radiação UV}

O estudo sobre a morte de células por radiação ultravioleta, em particular por comprimentos de ondas presentes na luz solar, já se desenvolve a mais de um século. A ação mutagênica da radiação UV foi experimentalmente estabelecida não muito mais tarde que a descoberta da mutagenecidade das radiações ionizantes de H. J. Muller em 1927. Concomitantemente, o espectro de ação para a morte de células e vírus e para a metagênese indica que esses efeitos ocorrem devido à absorção de energia em ácidos nucléicos, substâncias que fazem parte dos cromossomos e que carregam a informação hereditária (HARM, 1980).

Dessa maneira, a ação germicida da luz UV envolve determinados danos no conteúdo genético dos organismos. Os ácidos nucléicos são os mais importantes absorvedores de energia da luz no comprimento de onda na faixa de 240 a 280nm (WERF, 1995). Devido ao fato de o DNA e o RNA carregarem informação de reprodução, danos nestas substâncias podem efetivamente inativar as células. O dano geralmente resulta da dimerização de duas moléculas de pirimidina. Os três tipos de moléculas de pirimidina são citosina (encontrados no DNA e no RNA), timina (encontrado apenas no DNA) e uracila (encontrado apenas no RNA). Uma vez que as moléculas de pirimidina estiverem dimerizadas, a replicação dos ácidos nucléicos torna-se difícil assim que a estrutura helicoidal é destruída. Se a replicação ocorrer, células filhas mutantes serão produzidas e serão inábeis para se replicar (WERF, 1995).

A absorção de altas doses pelas proteínas presentes nas membranas celulares leva ao rompimento dessas membranas e, com isso, à morte da célula (DANIEL, 2001). Segundo o mesmo autor, a absorção de baixas doses pelo DNA pode interromper a habilidade de reprodução do microrganismo.

\subsection{Razão biológica da letalidade}

O material genético de um organismo celular ou um vírus tem que possuir duas funções essenciais para se reproduzir e perpetuar a identidade biológica: (1) ele deve se replicar, então o descendente carrega a mesma especificidade genética dos parentes, e (2) ele deve deixar disponível em certos componentes celulares a sua informação genética para assim prover todas as funções fenotípicas vitais. Conseqüentemente, os fotoprodutos de UV no 
DNA, através da interferência na replicação, transferência de informação ou ambos, podem causar a letalidade desses organismos celulares ou vírus.

\subsubsection{Recuperação de microrganismos irradiados por radiação UV}

Os microrganismos irradiados podem se recuperar através de dois mecanismos distintos, denominados de fotorreativação (reversão das alterações) e recuperação no escuro (substituição dos nucleotídeos lesados) (DANIEL, 1989).

A reversão das alterações é obtida por meio da recuperação fotoenzimática (fotorreativação) que monomeriza, principalmente, os dímeros de pirimidina. Isso ocorre através da ação de uma enzima fotorreativante durante a exposição em radiação ultravioleta de comprimento de onda de 300 a 500nm. Em $254 \mathrm{~nm}$ a formação de dímeros é aproximadamente 8 vezes mais freqüente que a desdimerização (COLLETI, 2003).

A substituição dos nucleotídeos lesados (reparo no escuro) ocorre na ausência da luz e pode ser realizada mediante a remoção da parte lesada e de uma sequência de nucleotídeos adjacentes, com posterior re-síntese da sequência original de nucleotídeos.

As vantagens do uso da radiação UV são (USEPA, 1999):

1. Eficácia na inativação da maioria dos vírus, esporos e cistos;

2. Por ser um processo físico, elimina a necessidade de geração, manuseio, transporte e estoque de produtos químicos tóxicos, perigosos ou corrosivos;

3. Não possui ação residual que possa prejudicar a vida aquática ou os seres humanos;

4. Inofensivo aos operadores, desde que não se exponham à radiação;

5. Os tempos de contato são inferiores aos de outros desinfetantes;

6. Os equipamentos requerem menores áreas do que em outros métodos.

As desvantagens do uso da radiação UV são (USEPA, 1999):

1. Doses baixas podem não ser suficientes para inativar alguns vírus, esporos ou cistos;

2. Alguns microrganismos podem reparar ou reverter os efeitos causados pela radiação UV através de mecanismos de fotorreativação ou recuperação no escuro;

3. Necessidade do controle de deposição de sólidos no envoltório das lâmpadas;

4. A concentração de sólidos suspensos totais e a turbidez das águas residuárias podem prejudicar a desinfecção;

5. Necessidade de eletricidade contínua (WITT \& REIFF, 1994);

6. Decrescimento da eficiência das lâmpadas com o uso (WITT \& REIFF, 1994);

7. Problemas operacionais como rompimento do quartzo das lâmpadas e necessidade de limpeza periódica das mesmas (SCHIRCH \& RODRIGUEZ, 1993). 
Se a qualidade do esgoto é ruim, a luz UV é incapaz de penetrar os sólidos e a eficiência do processo decresce. Por esta razão, recomenda-se tratar o efluente com SST $\leq 30 \mathrm{mg} / \mathrm{L}$ para se obter assim, uma elevada eficiência na desinfecção com UV (SPELLMAN, 1999).

\subsubsection{Fatores interferentes na eficácia da desinfeç̧ão com UV}

Os fatores interferentes na desinfecção com UV, segundo CHEREMISINOFF (1995), são:

1. A dose, que é afetada pela potência radiante das lâmpadas, tempo de contato e turbidez;

2. Presença de constituintes interferentes na água residuária, especialmente ferro, manganês e dureza (cálcio e magnésio);

3. Formação de curtos circuitos na câmara de contato.

LOGE et al., (1999) investigaram a influência dos sólidos na desinfecção com UV e fizeram as seguintes proposições: por proteger os microrganismos, o número de partículas presentes é provavelmente o parâmetro fundamental que influencia a eficiência do processo. Entretanto, devido à alta porosidade, a radiação pode somente penetrar nos sólidos, mas não por transmissão através dos sólidos. Por fim, os sólidos absorvem a radiação com atenuação, seguindo a lei de Beer-Lambert.

\subsection{Cinética de desinfecção}

Para melhor se entender o funcionamento dos efeitos da desinfecção em uma população de microrganismos torna-se necessário usar modelos matemáticos. Esses modelos têm por finalidade descrever o comportamento do número de organismos sobreviventes sujeitos à desinfecção, auxiliando as previsões de processos, ainda que esteja embutido um erro inerente da dificuldade de agregar os diversos fatores físicos, químicos e biológicos interferentes.

A eficiência da desinfecção depende da resistência dos microrganismos ao desinfetante e da concentração e do tempo de exposição ao agente desinfetante.

A probabilidade de se atingir um alvo é proporcional ao número de alvos, isto é, ao número de bactérias presentes. A intuição diz que ao se atirar ao acaso em muitos alvos, haverá boa chance de se abater um deles, mas com o tempo, não só o número de alvos diminui prontamente, como também se torna cada vez mais difícil se abater os remanescentes (PELCZAR, 1980). 
A probabilidade de atingir um alvo é também proporcional ao número de projéteis disparados, ou seja, à concentração do agente químico ou à intensidade do agente físico (PELCZAR et al., 1980).

Para água de abastecimento, deve-se alcançar a inativação total dos microrganismos patogênicos, devido aos riscos que podem causar à saúde dos consumidores e para a desinfecção de esgoto sanitário é permitido que a inativação forneça concentração compatível ao uso a que se propõe, alertando que o esgoto sanitário desinfetado nunca será usado como fonte de água potável, devido ao risco de conter patógenos e compostos orgânicos e inorgânicos prejudiciais à saúde humana (DANIEL, 2001).

O equacionamento da cinética é o mesmo para cloro, ozônio e UV. Há apenas adaptações que objetivam melhorar o ajuste matemático para descrever o efeito da ação de cada desinfetante. Para efeito didático, a cinética para cada desinfetante está descrita em itens distintos.

\subsubsection{Cinética de desinfecção com cloro}

Chick equacionou, em 1908, a redução do número de organismos viáveis de culturas puras de Bacillus anthracis seguindo a reação de primeira ordem, como mostra a equação 3.12 .

$\operatorname{Ln} \frac{N}{N o}=-K . t$

$\mathrm{K}$ : constante de decaimento $\left[\mathrm{T}^{-1}\right]$;

$\mathrm{N}$ : concentração final de microrganismos [NMP/100mL];

No: concentração inicial de microrganismos [NMP/100mL];

$\mathrm{T}$ : tempo de contato $[\mathrm{T}]$.

Essa equação é válida para as seguintes condições (DANIEL, 2001):

* População homogênea de microrganismo;

* Escoamento de pistão ou batelada de mistura completa;

* Distribuição homogênea de desinfetante e microrganismos;

* Concentração constante de desinfetante ao longo do tempo;

* A constante K é válida para cada concentração de desinfetante, não sendo aplicada para outras concentrações.

Divergências no decaimento exponencial da desinfecção são observadas e considerase que muitos fatores podem causar este desvio como, por exemplo, alteração na concentração 
de desinfetante com o tempo de contato, diferenças na resistência entre os organismos ou fase da vida em que os organismos se apresentam em uma mesma cultura, existência de grumos de organismos ou ainda a oclusão dos organismos por sólidos suspensos (U.S. EPA ${ }^{12}, 1986$ citado por WEF, 1996).

Em 1908, Watson, ao analisar dados com concentração variável de desinfetante, pode demonstrar uma relação logarítmica entre a concentração do desinfetante e a velocidade de reação (AWWA, 1995; U.S. EPA, 1986 citado por WEF, 1996; DANIEL, 2001), como mostra a equação (3.13).

$\operatorname{Ln} \frac{N}{N o}=-K^{\prime} \cdot C^{n} \cdot t$

C: concentração de desinfetante;

n: coeficiente de diluição;

$\mathrm{K}$ ': coeficiente de decaimento bacteriano;

t: tempo de contato.

Se $n>1$, a concentração de desinfetante exerce maior influência na desinfecção; se $n<1$, o tempo de contato exerce maior influência e se $n=1$, os efeitos da concentração e do tempo são iguais (DANIEL, 2001).

A inativação de microrganismos em experimentos de bancada, mesmo mantendo a concentração de desinfetante constante, nem sempre segue o decaimento exponencial predito na equação 3.12. De fato, podem ocorrer dois tipos de desvios como mostra a Figura 3.2 (AWWA, 1995).

\footnotetext{
${ }^{12}$ USEPA, 1986. U.S. Environmental Protection Agency. Municipal Wastewater Disinfection Design Manual. EPA-625/1-86-021, Cincinnati, Ohio, 247.
} 


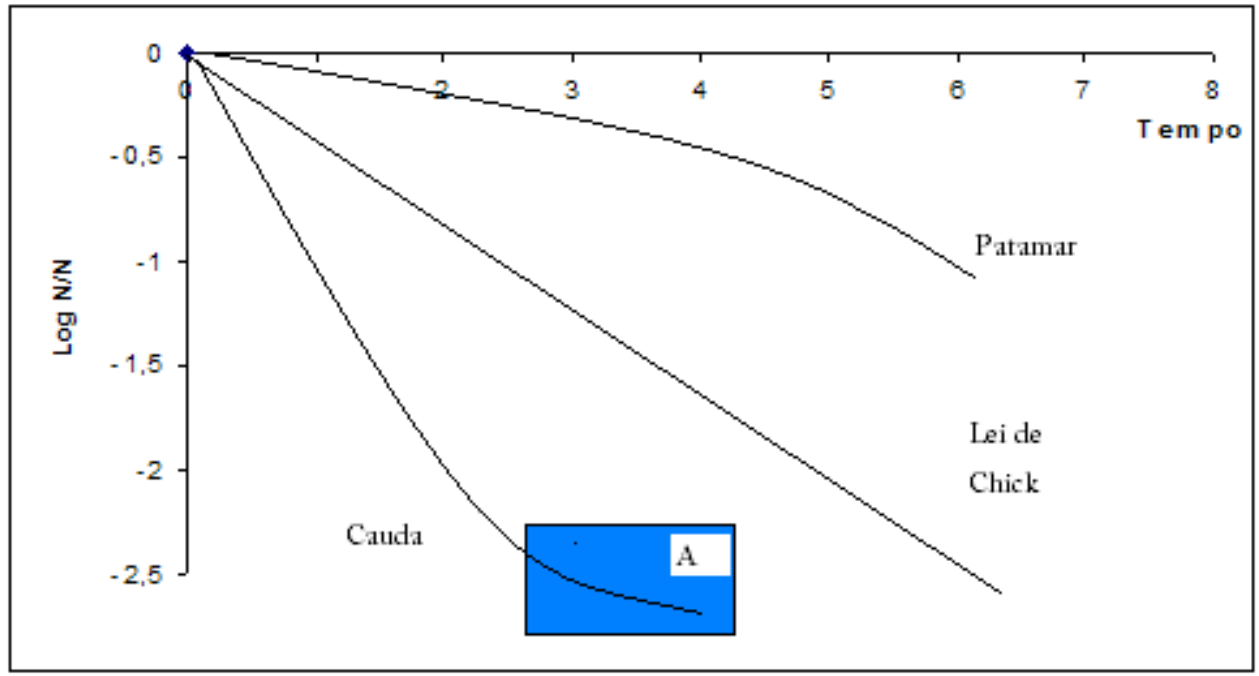

Figura 3.2: Lei de Chick e desvios.

$\mathrm{Na}$ desinfecção química, a concentração de desinfetante pode variar ao longo do tempo, e particularmente durante os momentos iniciais de contato, o cloro transforma-se rapidamente da forma livre para a combinada (AWWA, 1995). Segundo o mesmo autor, resultados obtidos em sistemas de bancada exibem tipicamente o comportamento de curva assíntota (tailing off). O grau deste comportamento depende da demanda e da concentração de constituintes reativos presentes no sistema, tais como a amônia. Esse comportamento pode representar que a parcela de microrganismos restante é resistente à desinfecção, ou que há a possibilidade de que partículas estejam protegendo os microrganismos mantendo uma fração sobrevivente mesmo em longo tempo de contato (na porção destacada A da Figura 3.2).

A presença de patamares (sholder) em curvas de inativação é geralmente presenciada em organismos que formam grumos, o que significa que mais de uma célula deve ser inativada para se obter a inativação de uma colônia (AWWA, 1995). Isso pode também ocorrer quando o organismo alvo é resistente ao desinfetante, exigindo um tempo de contato maior para que a inativação ocorra, ou quando ainda houver material em suspensão que possa proteger os microrganismos.

O comportamento de curva assíntota foi observado em inativação de coliformes e vírus usando-se ozônio e cloro livre (AWWA, 1995).

Em 1972, Hom desenvolveu um modelo mais flexível para descrever a cinética de inativação de microrganismos, como é apresentado na equação (3.14) (AWWA, 1995; WEF, 1996; DANIEL, 2001).

$\operatorname{Ln} \frac{N}{N o}=-K^{\prime} \cdot C^{n} \cdot t^{m}$

n e m: constantes empíricas. 
Para a equação 3.14, se m=1 a equação torna-se a lei Chick-Watson. Para $m>1$ resulta o comportamento assintótico (cauda), e para $\mathrm{m}<1$, de patamar (sholder).

As constantes e os coeficientes de todos os modelos de decaimento bacteriano são obtidos por regressão múltipla a partir de resultados experimentais obtidos em laboratório e em condições físico-químicas controladas e conhecidas. Alterando-se essas condições os valores dos coeficientes e das constantes deixam de ser válidos, podendo ocasionar erros que comprometerão a segurança, caso a inativação não alcance o resultado esperado. Assim, podese afirmar que a reprodutibilidade não pode ser garantida devido à variabilidade do recurso a ser desinfetado e à resistência dos organismos (DANIEL, 2001).

Os dados e as equações obtidas são válidos para estimativas e projetos, devendo sempre considerar o fator de segurança.

\subsubsection{Cinética de desinfecção com radiação UV}

A inativação bacteriana na ausência de material particulado é tipicamente modelada usando-se cinética de primeira ordem; esses modelos geralmente promovem uma boa aproximação para a inativação por radiação UV. No entanto, a presença de material particulado pode causar dificuldades na aplicação de modelos de primeira ordem para projetar sistemas reais. Prever níveis de inativação usando modelo de primeira ordem não explica a redução na eficiência da desinfecção devido à agregação de microrganismos ou à oclusão de bactérias na matéria particulada muito evidenciada em altas doses de UV. Inúmeras estações de tratamento de esgotos operam na região de curva assintótica (cauda) (WERF, 1995).

Uma limitação nos modelos de desinfecção existentes para UV está na habilidade em predizer com certeza o desempenho em regiões de cauda. É difícil descrever a inativação nessa região sem o uso de modelos empíricos devido à complexidade da absorção de partículas e à dispersão da luz UV. O uso de aproximações empíricas, por sua vez, introduz um nível de incerteza nas predições que passam a ser negligenciadas nos modelos existentes (WERF, 1995).

A agregação ou oclusão dos microrganismos na matéria particulada impede a penetração da radiação ultravioleta, reduzindo a eficiência da inativação (DANIEL, 1993).

A inativação bacteriana é usualmente aproximada pelo modelo de cinética de primeira ordem expressado na equação (3.15):

$\operatorname{Ln} \frac{N}{N o}=-K . I . t$ 
$\mathrm{N}$ : número de organismos sobreviventes após a exposição a radiação UV (UFC/100mL ou $\mathrm{NMP} / 100 \mathrm{~mL}$ );

No: número inicial de organismos (UFC/100mL ou NMP/100mL);

$\mathrm{K}$ : constante de inativação $\left(\mathrm{cm}^{2} / \mathrm{mWs}\right)$;

I: intensidade de energia de radiação UV $\left(\mathrm{mW} / \mathrm{cm}^{2}\right)$;

t: tempo de exposição (s).

Em analogia à equação (3.15), para este trabalho, foi empregado como dose recebida (Dr) o produto dos fatores de intensidade de energia de radiação UV (I) pelo tempo (t). Assim, a equação (3.15) foi expressa como na equação (3.16).

$\operatorname{Ln} \frac{N}{N o}=-K D r$

Dr: Dose recebida por volume $\left(\mathrm{Wh} / \mathrm{m}^{3}\right)$.

Embora o modelo de primeira ordem produza uma boa aproximação da inativação, desvios desse modelo incluem: retardo na resposta inicial da radiação UV devido à resistência das bactérias, e redução na eficiência da desinfecção devido à agregação de organismos ou de proteção das bactérias por conta do material particulado evidenciado em altas doses de UV (WERF, 1995). SHEIBLE ${ }^{13}$ (1987) considerou os efeitos da presença de matéria particulada em suspensão, fazendo distinção entre as frações de microrganismos agregados e não agregados aos sólidos (3.17) (DANIEL, 1993):

$$
N=\left(N_{m}+N_{p}\right) e^{\left(-k D_{r}\right)}+N_{p}
$$

$\mathrm{N}$ : número de organismos sobreviventes (NMP/100mL ou UFC/100mL);

$\mathrm{Nm}$ : número de organismos não associados à matéria particulada $(\mathrm{NMP} / 100 \mathrm{~mL}$ ou $\mathrm{UFC} / 100 \mathrm{~mL})$;

$\mathrm{Np}$ : número de organismos associados à matéria particulada, não afetados pela radiação ultravioleta (NMP/100mL ou UFC/100mL);

$\mathrm{k}$ : constante de inativação dos microrganismos pela radiação $\mathrm{UV}\left(\mathrm{cm}^{2} / \mathrm{mWs}\right)$;

Dr: Dose recebida por volume $\left(\mathrm{Wh} / \mathrm{m}^{3}\right)$.

\footnotetext{
${ }^{13}$ SHEIBLE , O. K. (1987). Development of a Rationally Based Protocl for the Ultraviolet Light Disinfection Process". J. Water Pollution Control Federation, v.59, n.1, 25-31, jan., 1987.
} 
Na maioria das aplicações para a desinfecção de esgoto, Nm é normalmente muito maior do que Np, permitindo que se faça a aproximação (3.18) (SHEIBLE, 1987 citado por DANIEL, 1993):

$N_{m}+N_{p}=N_{o}$

O Np pode ser estimado a partir da concentração de sólidos suspensos totais (SST) empregando-se uma dose suficiente para inativar todos os microrganismos que não estejam protegidos na matéria particulada e aplicando-se a seguinte relação empírica (3.19):

$N_{p}=\alpha(S S T)^{\beta}$

$\alpha, \beta$ : coeficientes empíricos.

As constantes $\alpha$ e $\beta$ podem ser determinadas através do ajuste pelo método dos mínimos quadrados ou ainda, graficamente, através da forma linear da equação (3.19) obtida através do lançamento $\mathrm{Np}$ em ordenadas logarítmicas e SST em abscissas também logarítmicas. A constante $\alpha$ é obtida pela interseção da reta com o eixo das ordenadas e a constante $\beta$ é a declividade da reta.

Combinando as equações (3.17); (3.18) e (3.19) obtém-se a 3.20:

$N=N o \exp \left(-K D_{r}\right)+\alpha(S S T)^{\beta}$

\subsubsection{Cinética de desinfeç̧ão com ozônio}

Se a reação de desinfecção com o ozônio ocorre conforme a lei de Chick, resulta-se em uma linha reta quando os dados são plotados em escala semi-logarítmica (tempo na abscissa - escala aritmética; log N/No - ordenada-escala logarítmica). Na prática, resultados experimentais nem sempre mostram uma relação linear. Esses desvios são devido a diferentes fatores, principalmente à agregação de microrganismos, à proteção de organismos por material particulado e à ausência de constância na concentração de desinfetante. Idade e condições físicas freqüentemente variam entre as populações, além disso, os organismos podem possuir material extracelular o que restringirá a difusão do desinfetante. Condições experimentais podem ter um efeito na eficiência de desinfecção. LANGLAIS (1991) considera a lei de Watson para a cinética do ozônio.

Para determinar a cinética para a desinfecção somente com ozônio, a definição de CT foi proposta partindo-se da equação (3.21) apresentada por WU \& DOAN (2005): 


$$
C T=\int_{0}^{t} C(t) t d t
$$

$\mathrm{C}(\mathrm{t})$ : concentração de ozônio dissolvido residual;

t: tempo de contato.

Para calcular CT, a equação de WU E DOAN (2005) foi modificada no presente trabalho, utilizando $\mathrm{C}(\mathrm{t}$ ) como taxa de ozônio consumido (concentração de ozônio consumido dividido pelo tempo de contato) e t como tempo de contato, considerando-se que a vazão aplicada de ozônio seja constante durante os ensaios.

A seguir é apresentado exemplo de como calcular CT:

Concentração de ozônio consumido $(\mathrm{C})=5,3 \mathrm{mg} / \mathrm{L}$;

Tempo de contato $(\mathrm{t})=10$ minutos;

Taxa de consumo de ozônio $=5,3 / 10=0,53 \mathrm{mg} \cdot \mathrm{min} / \mathrm{L}$;

Aplicando a equação 3.21:

$$
\mathrm{CT}=\int_{0}^{t} C_{(t)} t d t=\int_{0}^{10} 0,53 t d t=0,53 * \frac{t^{2}}{2}=0,53 * \frac{100}{2}=26,5 \mathrm{mg} \cdot \mathrm{min} / \mathrm{L}
$$

No estudo de WU \& DOAN (2005), em reator de semi-batelada a concentração de ozônio dissolvido variou com o tempo de contato. Esses autores observaram que a concentração de ozônio aumentou gradualmente com a aplicação contínua de ozônio até atingir um valor máximo. Nessas condições, o modelo que melhor se ajustou aos seus valores foi a equação (3.22).

$C=C_{0}\left(1-\exp ^{-k t}\right)$

Quando o ozônio é dissolvido no esgoto, três reações simultâneas ocorrem: desinfecção, oxidação química e a própria decomposição do ozônio. No esgoto estão presentes muitos materiais que consomem ozônio, além das bactérias. No processo da ozonização, bactérias são inativadas e materiais oxidáveis são mineralizados ou oxidados. Consequentemente, com a aplicação continua de ozônio, o consumo de ozônio dissolvido diminue e eventualmente, um equilíbrio entre a produção e o consumo desse gás alcança uma dada dose de ozônio aplicada que poderá estar mais disponível para agir como desinfetante. 


\section{Material e Métodos}

\subsection{Ensaios de desinfecção com cloro seguido de radiação UV}

O ensaio teve por início a coleta do efluente no reator UASB localizado na estação de tratamento de esgoto do campus da USP - São Carlos, Área 1. Esse esgoto foi coletado e levado até o Laboratório de Tratamento Avançado e Reuso de Águas (LATAR), localizado no próprio campus, onde foram realizados os experimentos e as análises.

O efluente anaeróbio utilizado foi proveniente do reator UASB localizado na ETEUSP - SC. Esse reator possui 2,0 $\mathrm{m}$ de lado e 4,7 $\mathrm{m}$ de altura útil, com volume total de 18,8 $\mathrm{m}^{3}$. O reator UASB foi alimentado com esgoto sanitário in natura proveniente do Campus I da USP e de parte da rede coletora do bairro próximo ao Campus, o qual foi submetido a tratamento preliminar (gradeamento, remoção de areia e remoção de gorduras). Após o tratamento preliminar, o esgoto era bombeado para um tanque pulmão e distribuído por gravidade para o reator UASB (PASSIG, 2005).

O reator anaeróbio de manta de lodo (UASB) é uma unidade de tratamento de fluxo ascendente, que utiliza o processo anaeróbio para degradar a matéria orgânica. A água residuária passa através de uma região de reação que apresenta elevada concentração de microrganismos anaeróbios (PASSIG, 2005).

Os ensaios de desinfecção foram realizados em duas fases: Fase I - Desinfecção com cloro e Fase II - Desinfecção sequencial com cloro e radiação ultravioleta.

\subsubsection{Fase I - Ensaios de desinfecção com cloro}

A solução de hipoclorito de sódio utilizada era de grau comercial. Essa solução, que será chamada de estoque ao longo do texto, deve ser mantida refrigerada ao abrigo de luz, pois, devido o seu alto poder de oxidação, soluções de hipoclorito de sódio são instáveis. Calor, luz, tempo de armazenamento e impurezas, como o ferro, aceleram a decomposição do produto (SPELLMAN, 1999).

Essa instabilidade exige que se tenha o rigor de sempre aguardar que a solução estoque se equalize com a temperatura ambiente e quantificar sua concentração imediatamente antes de seu uso.

O ensaio de desinfecção com cloro consiste em aplicar uma alíquota de solução estoque de cloro, que corresponda à concentração desejada, no efluente do reator UASB; misturar o desinfetante e agitar durante todo o tempo de contato desejado. 
A amostra a ser clorada foi acondicionada em béqueres de vidro de 2 L. Para garantir a mesma agitação para toda a amostra foi usado o equipamento Jar Teste a $70 \mathrm{rpm}$.

As dosagens de cloro usadas foram de 10, 20 e $30 \mathrm{mgCl}_{2} / \mathrm{L}$. Para cada dosagem de cloro, o esgoto foi submetido a 3 tempos de contanto: 10, 20 e 30 min. Para cada combinação de dosagem de cloro e tempo de contato o esgoto clorado foi submetido a 3 doses de radiação ultravioleta: 1,5 e $10 \mathrm{Wh} / \mathrm{m}^{3}$ (Tabela 4.1).

Tabela 4.1: Configuração dos experimentos de desinfecção com cloro seguido de UV

\begin{tabular}{cccc}
\hline Experimento & $\begin{array}{c}\text { Dosagem } \\
\text { cloro } \\
\left(\mathrm{mgCl}_{2} / \mathrm{L}\right)\end{array}$ & $\begin{array}{c}\text { Tempo de } \\
\text { contato } \\
(\text { min. })\end{array}$ & $\begin{array}{c}\text { Dose Radiação UV } \\
\left(\mathrm{Wh} / \mathrm{m}^{3}\right)\end{array}$ \\
\hline \hline I-A & 10 & 10 & $1 ; 5 ; 10$ \\
I-B & $\overline{10}$ & $\overline{20}$ & $1 ; 5 ; 10$ \\
II & 10 & 30 & $1 ; 5 ; 10$ \\
III & 20 & 10 & $1 ; 5 ; 10$ \\
IV & 20 & 20 & $1 ; 5 ; 10$ \\
V & 20 & 30 & $1 ; 5 ; 10$ \\
VI & 30 & 10 & $1 ; 5 ; 10$ \\
VII & 30 & 20 & $1 ; 5 ; 10$ \\
VIII & 30 & 30 & $1 ; 5 ; 10$ \\
IX & & & $1 ; 5 ; 10$ \\
\hline
\end{tabular}

O cloro aplicado e as concentrações de cloro total e livre na fase líquida foram quantificados pelo método DPD Colorimétrico. Foi utilizado o programa 88 do manual do espectrofotômetro Hack- DR 2010, em comprimento de onda de $530 \mathrm{~nm}$.

Foi definido antes de cada ensaio, o volume de solução estoque de hipoclorito de sódio a ser adicionado no efluente do reator UASB de forma a se obter a dosagem desejada. $\mathrm{O}$ procedimento constitui em transferir uma alíquota de solução estoque de hipoclorito de sódio para um béquer contendo água desionizada em volume igual ao do esgoto a ser desinfetado. A solução foi homogeneizada e a concentração do cloro nessa solução foi determinada pelo método DPD colorimétrico.

Conhecendo-se a concentração da solução estoque na solução com água desionizada, calcula-se o volume da solução estoque a ser usado para se obter a concentração desejada no ensaio de desinfecção pela equação (4.1):

$$
V_{c}=\frac{C_{a+c} \times V_{a+c}}{C_{c}}
$$

$\mathrm{V}_{\mathrm{c}}$ : volume de solução estoque $(\mathrm{mL})$;

$\mathrm{V}_{\mathrm{a}+\mathrm{c}}$ : volume da solução de água desionizada com solução estoque $(\mathrm{mL})$;

$\mathrm{C}_{\mathrm{c}}$ : concentração de cloro na solução estoque $(\mathrm{mg} / \mathrm{L})$; 
$\mathrm{C}_{\mathrm{a}+\mathrm{c}}$ : concentração de cloro na solução de água desionizada com solução estoque $(\mathrm{mL})$.

Definido o volume de solução estoque, iniciou-se o ensaio de desinfecção, transferindo-o para os béqueres com amostra de efluente do reator UASB. Ligou-se a agitação pelo tempo de contato especificado para cada dosagem (Tabela 4.1).

Concluído o tempo de contato, coletou-se alíquota e determinaram-se as concentrações de cloro livre e do cloro total. Em outra alíquota destinada às análises fisicoquímicas e aos exames para quantificação de E. coli, coliformes totais e C. perfringens, foi adicionado metabissulfito de sódio para remover o cloro residual livre e combinado.

O metabissulfito reage com o cloro segundo a reação (4.2):

$\mathrm{Na}_{2} \mathrm{~S}_{2} \mathrm{O}_{5}+4 \mathrm{HOCl}+\mathrm{H}_{2} \mathrm{O} \rightarrow 6 \mathrm{H}++2 \mathrm{SO}_{4}{ }^{2-}+4 \mathrm{Cl}^{-}+2 \mathrm{Na}^{+}$

\subsubsection{Fase II - Ensaios de desinfecção com radiação ultravioleta}

A desinfecção com radiação ultravioleta foi realizada em reator de bancada (batelada), constituído com base em aço inoxidável e com as dimensões: 40,2cm de largura, 44,8 cm de comprimento e $10 \mathrm{~cm}$ de profundidade. Sobre essa base foi fixado um refletor em alumínio com 44,4 cm de comprimento, 39,6 cm de largura e $10 \mathrm{~cm}$ de altura, contendo 6 lâmpadas de $15 \mathrm{~W}$, de baixa pressão de vapor de mercúrio e uniformemente espaçadas, conforme apresentado na Figura 4.1. Trata-se de reator de lâmpadas emersas, as quais não têm contato direto com o líquido.
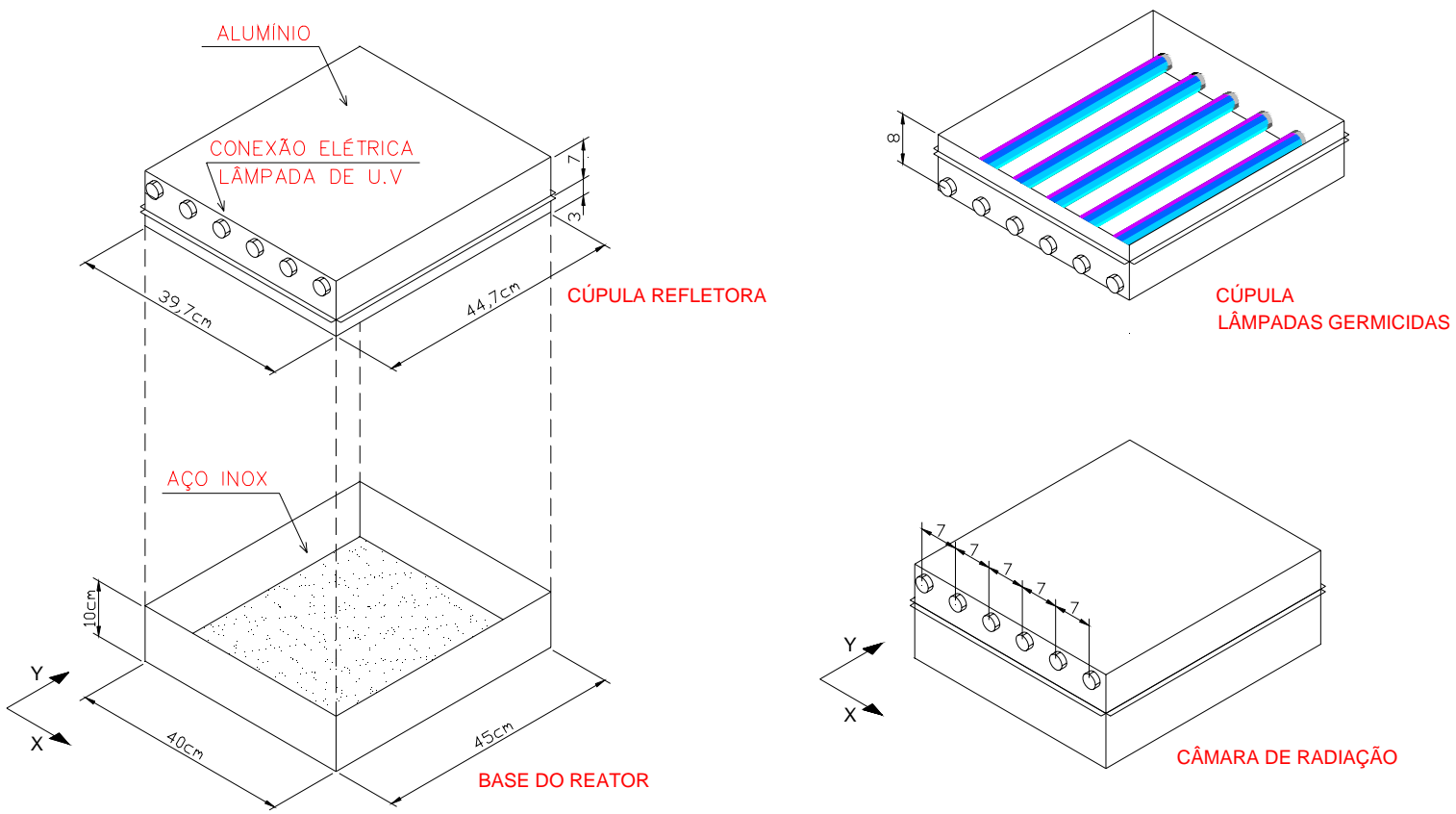

Figura 4.1: Ilustração do reator usado na desinfecção com radiação UV. 
Antes de se iniciar o ensaio com a radiação ultravioleta foi necessário avaliar a intensidade de radiação média no interior do reator. Essa quantificação foi feita por radiometria, definindo-se o número de pontos equidistantes das paredes do reator (Figura 4.2). Em cada ponto foi medida a radiação em comprimento de onda de $254 \mathrm{~nm}$. Com o valor de todos os pontos, determina-se a intensidade média ponderada de radiação emitida pelas lâmpadas (Io) aplicando-se a equação (4.3):

$$
I o=\frac{I_{1} \times a_{1}+I_{2} \times a_{2} \ldots \ldots I_{n} \times a_{n}}{\sum a}
$$

$\mathrm{I}_{\mathrm{o}}$ : Intensidade de radiação UV na superfície do reator $\left(\mathrm{mW} / \mathrm{cm}^{2}\right)$;

$\mathrm{I}_{\mathrm{i}}$ : Intensidade de radiação UV no ponto de medição i $\left(\mathrm{mW} / \mathrm{cm}^{2}\right)$;

$\mathrm{a}_{\mathrm{i}}$ : área de influência do ponto de medição i;

i: $1,2,3 \ldots$ pontos de medição.

a

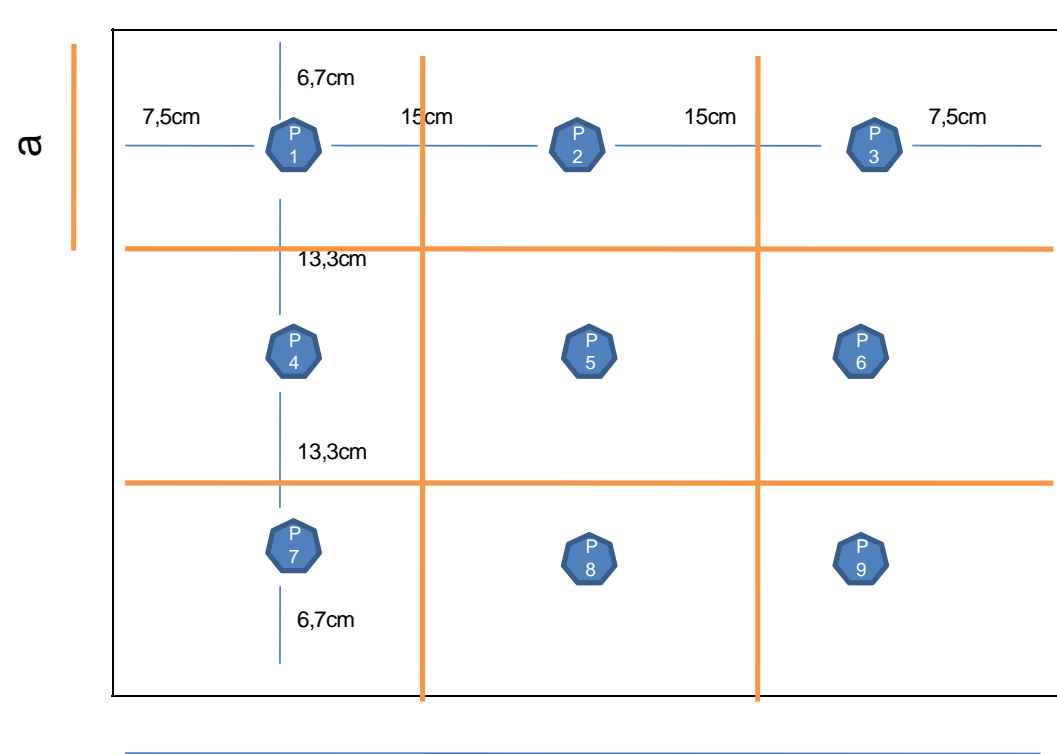

$40 \mathrm{~cm}$

\section{$45 \mathrm{~cm}$}

Figura 4.2: Localização dos pontos de medição da radiação UV no reator

O valor de Io deve ser calculado periodicamente, pois a radiação emitida pelas lâmpadas diminui com o passar do tempo. Para o presente trabalho, o valor de Io foi usado no máximo por dois meses, ou a cada 10 ensaios.

Com os valores de Io e de absorbância em comprimento de onda de $254 \mathrm{~nm}$, sempre medidos antes de se iniciar os ensaios com radiação ultravioleta, a intensidade média de radiação (Im) foi calculada pela equação (4.4). 


$$
I_{m}=\frac{I_{o}}{a \cdot L}[1-\exp (-a . L)]
$$

A: absorbância a $254 \mathrm{~nm}$, em cubeta de $1,0 \mathrm{~cm}$;

L: espessura da lâmina líquida ou trajetória percorrida pela radiação ultravioleta $(\mathrm{cm})$.

a: coeficiente de extinção $\left(\mathrm{cm}^{-1}\right)$

$\mathrm{a}=2,203 . \mathrm{A}$

Com o valor de $\mathrm{I}_{\mathrm{m}}$, pode-se determinar a dose recebida por volume (equação 4.6):

$D_{r}=\frac{I_{m} \cdot t}{L} 0,2778$

$\mathrm{I}_{\mathrm{m}}$ : intensidade média de radiação ultravioleta $\left(\mathrm{mW} / \mathrm{cm}^{2}\right)$;

$\mathrm{D}_{\mathrm{r}}$ : dose recebida por volume $\left(\mathrm{Wh} / \mathrm{m}^{3}\right)$;

0,2778: fator de conversão de $\mathrm{mW}$ para $\mathrm{W}$, s para $\mathrm{h}$ e $\mathrm{cm}$ para $\mathrm{m}$.

COLETTI (2003) conceitua que a dose recebida é a energia total efetivamente disponível para inativação dos microrganismos, sendo influenciada pelas características das águas residuárias desinfetadas, principalmente absorbância e SST e pela espessura da lâmina líquida.

O tempo de contato foi calculado a partir da dose recebida e estipulado para cada ensaio, utilizando a equação (4.6).

Em todos os ensaios realizados, a espessura de lâmina líquida de esgoto foi de 3,0 cm.

Após a conclusão de cada ensaio, uma alíquota de esgoto foi coletada para posteriores análises microbiológicas e de $\mathrm{pH}$.

As concentrações de cloro residual livre e total foram quantificadas após a conclusão dos ensaios com a aplicação de radiação ultravioleta, objetivando dessa forma, avaliar o efeito dessa radiação no cloro remanescente.

Assim então, a fim de se remover o cloro residual livre e combinado, era adicionado o metabissulfito de sódio nas amostras coletadas após a exposição à radiação ultravioleta.

\subsection{Ensaio de desinfecção com ozônio seguido de radiação $U V$}

O efluente do reator anaeróbio da ETE da USP de São Carlos foi bombeado para uma caixa com o objetivo de ser decantado. Após a decantação, foi bombeado para a coluna de ozonização. 
Finalizada a ozonização, o efluente foi levado para o Laboratório de Tratamento Avançado e Reuso de Águas (LATAR), onde foram realizados os ensaios com radiação UV e a caracterização físico-química e microbiológica.

O ensaio de desinfecção consistiu das fases I e II. Na fase I, o efluente do reator anaeróbio foi submetido à ozonização e na fase II subseqüente esse efluente ozonizado foi submetido a três doses crescentes de radiação ultravioleta.

\subsubsection{Fase I - Ensaios de desinfecção com ozônio}

O ensaio tem por início a coleta do efluente do reator UASB localizado na estação de tratamento de esgoto do campus da USP - São Carlos, Área 1. Esse esgoto foi bombeado até uma caixa d' água de 350L, onde foi decantado por aproximadamente 40 minutos, para então ser bombeado para a coluna de ozonização.

A amostra de esgoto, antes da desinfecção, foi coletada na própria coluna de ozonização. Neste ínterim, o ozonizador ficou ligado por pelo menos 10 minutos, injetando gás oxigênio para haver a estabilização do aparelho. A instalação experimental de ozonização adotada foi a mesma usada no trabalho de SOARES (2007) (Figura 4.3). A coluna de ozonização foi preenchida com 15,1L de efluente decantado.

Na base da coluna havia um registro de agulha para controle da vazão de gás, um registro de esfera conectado ao dreno (esvaziamento da coluna de contato) e um registro de esfera conectado à tubulação para coleta de amostras.
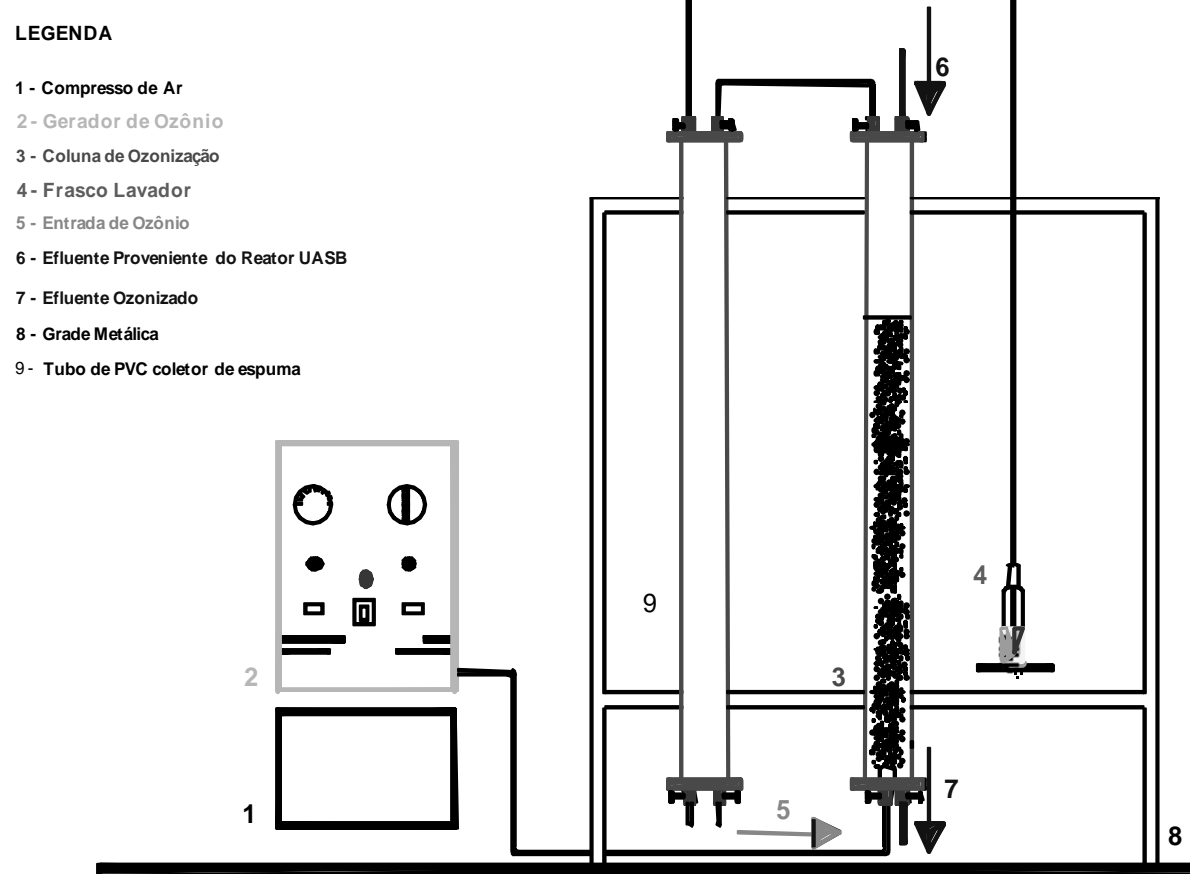

Figura 4.3: Esquema da unidade piloto utilizada nos ensaios de ozonização. 
Feito o ajuste da vazão de ozônio, da tensão de produção de ozônio, colocação de 600 $\mathrm{mL}$ de solução de KI 2\%* no frasco lavador, verificação do frasco lavador devidamente conectado à coluna de ozonização através de uma mangueira de silicone e verificação da ocorrência do borbulhamento na coluna de ozonização e do frasco lavador, dava-se como iniciada a desinfecção ao se abrir a válvula de alimentação de ozônio.

Passado o tempo de contato, o ozonizador era desligado, coletava-se $200 \mathrm{~mL}$ de solução de KI do frasco lavador e $50 \mathrm{~mL}$ da coluna de ozonização, para se verificar a concentração de ozônio que não reagiu com o esgoto (off-gas) e o que sobrou dissolvido no esgoto ozonizado, respectivamente.

As amostras foram coletadas após desligar o gerador de oxigênio, fechar o registro que envia ar para a coluna de ozonização e abrir o registro do topo da coluna para que o ar acima do nível de esgoto fosse liberado.

Executada a desinfecção, o efluente ozonizado era armazenado para posterior desinfecção com radiação UV. O efluente ozonizado excedente era descartado e abria-se o registro de água para lavar a coluna por três vezes. Após o ensaio, a coluna era preenchida com água até o próximo ensaio, visando evitar assim o seu ressecamento.

As doses de ozônio usadas no ensaio foram de aproximadamente 5,6;11,1 e 16,7 $\mathrm{mgO}_{3} / \mathrm{L}$. Para cada dose de ozônio, o esgoto foi submetido a 3 tempos de contanto: 10, 20 e 30 min. Para cada combinação de concentração de ozônio e tempo de contato, o esgoto ozonizado foi submetido a 3 doses crescentes de radiação ultravioleta. Na Tabela 4.2 estão apresentados os ensaios realizados.

Tabela 4.2

\footnotetext{
* A solução de KI $2 \%$ é preparada adicionando $20 \mathrm{~g}$ de iodeto de potássio para cada $1 \mathrm{~L}$ de água. Esta solução deve ser armazenada no escuro, refrigerada e preparada $48 \mathrm{~h}$ antes de seu uso. Esse procedimento é necessário para ocorrer a maturação da solução.
} 
Tabela 4.2: Configuração dos experimentos de desinfecção com ozônio seguido de UV.

\begin{tabular}{cccccc}
\hline Experimentos & $\begin{array}{c}\text { Dose de Ozônio } \\
\left(\mathrm{mgO}_{3} / \mathrm{L}\right)\end{array}$ & $\begin{array}{c}\text { Tempo de } \\
\text { contato } \\
(\mathrm{min})\end{array}$ & $\begin{array}{c}\text { Dose } \mathrm{UV}_{1} \\
\left(\mathrm{Wh} / \mathrm{m}^{3}\right)\end{array}$ & $\begin{array}{c}\text { Dose } \mathrm{UV}_{2} \\
\left(\mathrm{Wh} / \mathrm{m}^{3}\right)\end{array}$ & $\begin{array}{c}\text { Dose } \mathrm{UV}_{3} \\
\left(\mathrm{Wh} / \mathrm{m}^{3}\right)\end{array}$ \\
\hline O-A & 5,6 & 10 & 1 & 3 & 5 \\
O-B & & & 1 & 3 & 5 \\
I & 5,6 & 10 & 1 & 5 & 10 \\
II & 5,6 & 20 & 1 & 3 & 5 \\
III-A & 5,6 & 30 & 1 & 3 & 5 \\
III-B & 5,6 & 30 & 0,5 & 1 & 1,5 \\
IV & 10,5 & 10 & 1 & 5 & 10 \\
V-A & 11,1 & 20 & 1 & 3 & 5 \\
V-B & 11,1 & 20 & 1 & 2 & 3 \\
VI & 11,1 & 30 & 1 & 3 & 5 \\
VII & 15,8 & 10 & 1 & 3 & 5 \\
VIII & 16,7 & 20 & 1 & 3 & 5 \\
IX & 16,7 & 30 & 1 & 3 & 5 \\
\hline
\end{tabular}

\subsubsection{Quantificação do ozônio}

Nos ensaios realizados, o ozônio esteve presente na fase gasosa e dissolvido na fase líquida (esgoto). Os procedimentos analíticos para a quantificação devem ser adequados às formas em que o ozônio está presente.

Para a fase gasosa, foi utilizado o método Iodométrico (APHA, 1998). Para a fase líquida, foi utilizado o método colorimétrico, usando espectrofotômetro da marca Prominent ${ }^{\circledR}$ - modelo DULCOTEST DT 11 e reagentes da Merck, código Chlor- test 1.14803.001.

No método Iodométrico, o ozônio é medido indiretamente pela reação de oxidação do iodeto. A reação usada para determinar a quantidade de ozônio no ar ou na água pode ser a reação de liberação de iodo de uma solução de iodeto de potássio conforme a reação 4.7. Para maiores informações sobre esta método vide Apêndice A.

$\mathrm{O}_{3}+2 \mathrm{KI}+\mathrm{H}_{2} \mathrm{O} \rightarrow \mathrm{I}_{2}+\mathrm{O}_{2}+\mathrm{KOH}$ 
Para a quantificação do ozônio na fase gasosa, borbulha-se o gás em solução de iodeto de potássio $2 \%$. A quantificação do ozônio é feita acidulando-se a solução oxidada e titulando-a com solução de tiossulfato de sódio, usando o amido como indicador.

O ozônio dissolvido na fase líquida pode ser quantificado pelo método iodométrico. Entretanto, devido ao fato de a concentração de ozônio ser normalmente pequena, o procedimento depende do arraste de ozônio dissolvido por gás inerte e a coleta do mesmo em solução de iodeto de potássio. Essas operações tornam o procedimento impreciso (JOHNSON, 1975). Essa é razão que explica o motivo dessa parcela de ozônio ter sido quantificada utilizando-se o método colorimétrico.

\subsubsection{Calibração do Gerador de Ozônio}

O gerador de ozônio foi calibrado variando-se a vazão de gás e a tensão no equipamento. A partir dos resultados da calibração, foram construídas curvas de calibração relacionando a vazão de gás com a produção do equipamento em $\mathrm{gO}_{3} / \mathrm{h}$.

O método usado para calibrar o aparelho gerador de ozônio foi o iodométrico, seguindo o procedimento descrito em APHA (1998). O método parte do princípio que o ozônio tem a capacidade de gerar iodo em solução de iodeto de potássio a $2 \%$ em meio ácido. A solução de iodeto de potássio $2 \%$ é ozonizada e titulada com solução de tiossulfato de sódio $\left(\mathrm{Na}_{2} \mathrm{~S}_{2} \mathrm{O}_{3}\right)$ 0,025N utilizando solução de amido como indicador (SOARES, 2007).

\section{Procedimento para calibração do gerador de ozônio}

O procedimento usado seguiu o mesmo adotado por SOARES (2007), como está descrito a seguir:

1- Adicionar à coluna de ozonização e ao frasco lavador volumes de KI $2 \%$. Esses volumes adotados devem ser mantidos para todos os pontos das curvas de calibração;

2- Ajustar a primeira vazão de ozônio no rotâmetro, acertar a primeira tensão de produção de ozônio, ozonizar durante o tempo de contato de 3 a 15 minutos e anotar o tempo adotado;

3- Depois de transcorrido o tempo de contato, coletar volumes de amostra da coluna de ozonização e do frasco lavador, fixando-as com solução de ácido sulfúrico $\left(\mathrm{H}_{2} \mathrm{SO}_{4}\right)$ $1 \mathrm{~N}$, na proporção de $2 \mathrm{~mL}$ de $\mathrm{H}_{2} \mathrm{SO}_{4}$ para cada $100 \mathrm{~mL}$ de amostra; fazer em duplicata ou triplicata; 
4- $\quad$ Em seguida, titular cada amostra com tiossulfato de sódio $(0,025 \mathrm{~N})$ até que ela apresente-se com a cor amarelo-palha;

5- $\quad$ Adicionar $2 \mathrm{~mL}$ de solução indicadora de amido (APHA, 1998) para cada 200 $\mathrm{mL}$ de amostra. Este indicador deixará a amostra azulada;

6- Continuar a titulação com o tiossulfato até a amostra ficar transparente, anotar o volume total de tiossulfato de sódio usado.

7- $\quad$ Com os resultados de volume de tiossulfato usados, determina-se a produção de ozônio utilizando-se a equação (4.8):

$P=\frac{N_{t i o} x\left(V_{t i o}-V_{b}\right) x V_{K I} x 1440}{V_{a m} x t}$

P: produção de ozônio, $\mathrm{g} \mathrm{O}_{3} / \mathrm{h}$;

$\mathrm{N}$ : normalidade do tiossulfato (Número de equivalente-grama/L);

$\mathrm{V}_{\text {tio: }}$ : volume de tiossulfato de sódio gasto na titulação da amostra, $\mathrm{mL}$;

$\mathrm{V}_{\mathrm{b}}$ : volume de tiossulfato de sódio gasto na titulação do branco, $\mathrm{mL}$;

$\mathrm{V}_{\mathrm{KI}}$ : volume de iodeto de potássio a $2 \%$ adicionado na coluna de ozonização ou no frasco lavador de gás, L;

$\mathrm{V}_{\mathrm{am}}$ : volume da amostra a ser titulada, $\mathrm{mL}$;

t: tempo de contato, min;

1440: fator de conversão.

8- Repetir o procedimento para as demais vazões e tensões de produção de ozônio.

A produção total de ozônio é dada pela soma das parcelas individuais da coluna de ozonização e do off-gas.

A dosagem de ozônio está relacionada à produção de ozônio pela equação (4.9):

$D=\frac{P x t x 1000}{V x 60}$

D: dosagem de ozônio aplicado, mg/L;

P: produção de ozônio, $\mathrm{g} \mathrm{O}_{3} / \mathrm{L}$;

t: tempo de contato, min;

V: volume ozonizado, L.

É importante evidenciar que para ensaios com a mesma produção de ozônio, mesmo volume de efluente e tempo de contato diferente, a dosagem de ozônio aplicado será diferente. 
Isso se dá devido ao fato de que a dosagem é um valor médio da concentração de ozônio durante um determinado tempo de contato (SOARES, 2007).

\section{Preparação do branco}

1- O branco consiste em colocar $200 \mathrm{~mL}$ de solução de iodeto de potássio $2 \%$, previamente preparada e não ozonizada em dois frascos erlenmeyer (duplicata),

2- $\quad$ Acidificar com $10 \mathrm{~mL}$ de ácido sulfúrico $1 \mathrm{~N}$ em cada um dos frascos;

3- $\quad$ Adicionar $2 \mathrm{~mL}$ de solução de amido em cada uma das réplicas;

4- Titular com tiossulfato de sódio $(0,025 \mathrm{~N})$ até a cor azulada do indicador atingir a cor transparente, e anotar o volume gasto de tiossulfato.

Nota: A solução de KI não oxidada com ozônio é incolor. Por isso, a fase de titulação até a cor amarelo-palha não é realizada na titulação com o branco.

\section{Valores usados para a calibração do gerador de ozônio}

A calibração do gerador usado nesta pesquisa foi feita adotando os seguintes valores:

* Volume de KI na coluna de ozonização: 4,4 L(SOARES, 2007);

* Volume de KI no frasco lavador: $400 \mathrm{~mL}$;

* Tempo de contato: 5 min;

* Volumes de amostra: $100 \mathrm{~mL}$;

* Normalidade do tiossulfato de sódio padronizado: $0,0125 \mathrm{~N}$ vide apêndice A.

* Vazões de gás ozônio (oxigênio a 98 \%): 60, 108, 180, 240 L/h;

* Tensão de produção de ozônio: 40\%, 60\%, 80\% e 100\%.

\subsubsection{Balanço de massa do ozônio dissolvido na fase líquida}

No balanço de massa de ozônio, é possível quantificar a massa ou concentração de ozônio transferido e consumido durante os ensaios de ozonização e associar esses resultados à eficiência de inativação dos microrganismos indicadores (SOARES, 2007).

Nos ensaios, utilizou-se a produção de ozônio desejada para se obter a dosagem requerida. No final do ensaio, obtém-se a concentração de ozônio residual presente no efluente ozonizado e a concentração de ozônio que não reagiu com o efluente e é capturado pelo iodeto de potássio a $\%$ presente no frasco lavador, como é ilustrado na Figura 4.4. 


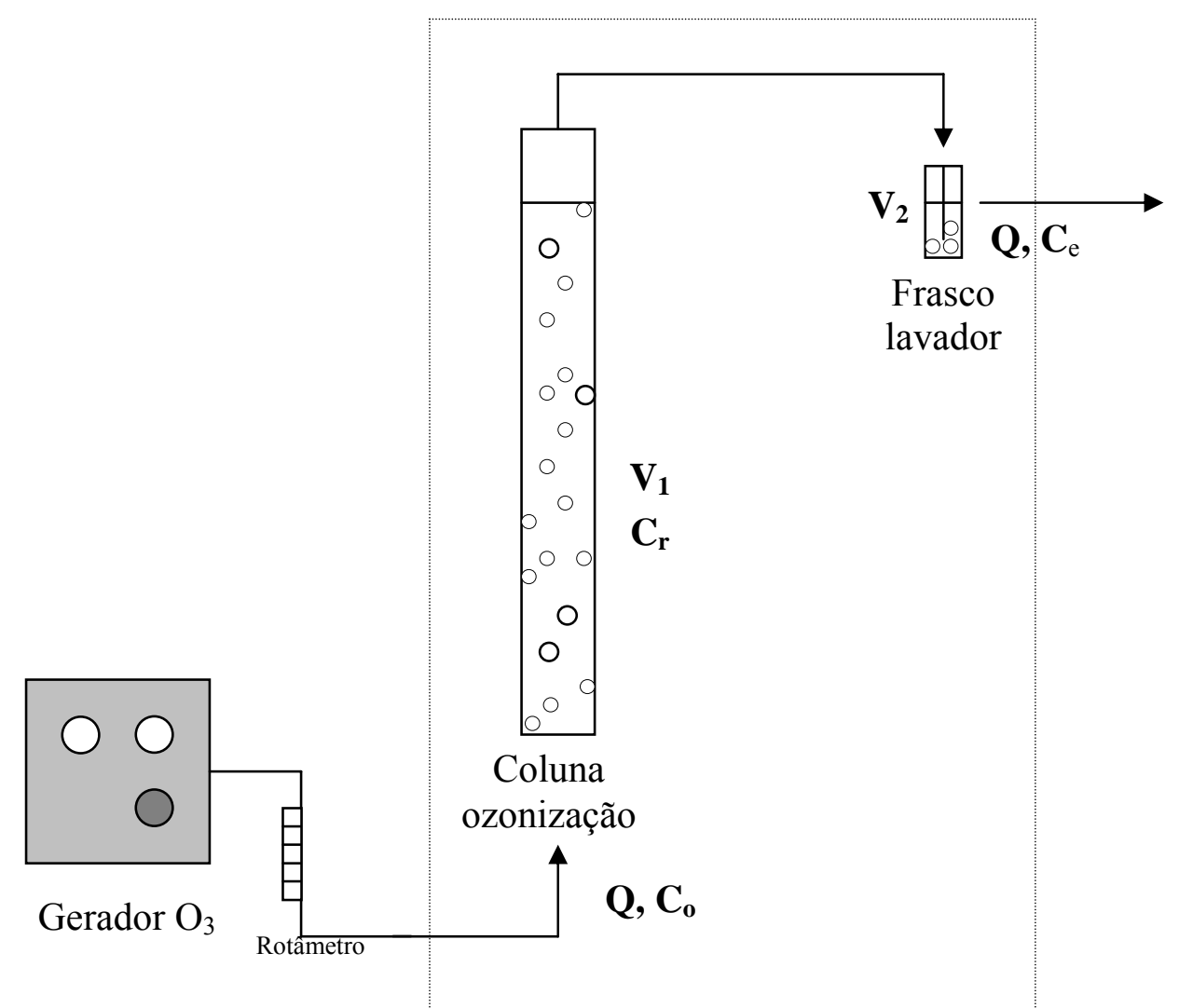

Figura 4.4: Representação do volume de controle para obtenção do balanço de ozônio (linha

\section{Legenda:} tracejada).

$\mathrm{C}_{0}$ : concentração de $\mathrm{O}_{3}$ afluente-fase gasosa;

$\mathrm{C}_{\mathrm{e}}$ : concentração de $\mathrm{O}_{3}$ efluente-fase gasosa (Off-gas);

$\mathrm{C}_{\mathrm{r}}$ : concentração de $\mathrm{O}_{3}$ dissolvido na fase líquida (residual);

Q: vazão de gás aplicada $(\mathrm{L} / \mathrm{h})$;

$\mathrm{V}_{1}$ : Volume de solução de KI a 2\% na coluna de ozonização (para a calibração) ou volume de esgoto (ensaio de desinfecção);

$\mathrm{V}_{2}$ : volume de solução de KI a 2\% no frasco lavador de gás.

Apresentam-se, a seguir, todas as variáveis do balanço de massa do ozônio e suas relações.

Durante o ensaio de ozonização foi aplicado massa de ozônio $\left(\mathrm{M}_{\mathrm{A}}\right)$ no volume de efluente inserido na coluna de ozonização. Essa massa é obtida pelo produto da dosagem de ozônio aplicada pelo volume de efluente ozonizado (equação 4.10).

$\mathrm{M}_{\mathrm{A}}=\mathrm{D} \times \mathrm{V}$

$\mathrm{M}_{\mathrm{A}}$ : massa de ozônio aplicado (mg). 
A massa de ozônio aplicada durante o ensaio transforma-se em massa de ozônio transferida $\left(\mathrm{M}_{\mathrm{T}}\right)$ (equação 4.11) para o meio líquido presente na coluna de ozonização e em massa não transferida, quantificada no off-gas (Moff-gas) (equação 4.12).

$\mathrm{M}_{\mathrm{T}}=\mathrm{M}_{\mathrm{A}}$ - Moff-gas

$M_{\text {off }- \text { gas }}=\frac{N_{\text {tio }} x\left(V_{\text {tio }}-V_{b}\right) x V_{\text {off-gas }} x 24000}{V_{a m}}$

$\mathrm{M}_{\mathrm{T}}$ : massa de ozônio transferida;

$\mathrm{M}_{\text {off-gas: }}$ : massa de ozônio no off-gas;

$\mathrm{N}$ : normalidade do tiossulfato de sódio;

$\mathrm{V}_{\text {tio }}$ e $\mathrm{V}_{\mathrm{b}}$ : volumes de tiossulfato de sódio gastos na titulação da amostra e do branco, $\mathrm{mL}$;

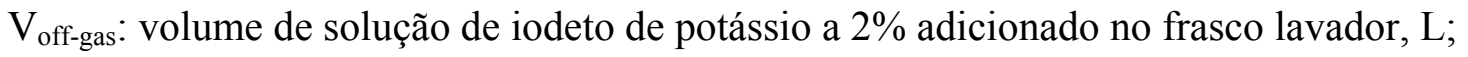

$\mathrm{V}_{\mathrm{am}}$ : volume de amostra de iodeto de potássio $2 \%$ titulada, $\mathrm{mL}$.

A massa de ozônio transferida corresponde à soma da massa residual (equação 4.13) $\left(\mathrm{M}_{\mathrm{R}}\right)$ e da massa consumida $\left(\mathrm{M}_{\mathrm{C}}\right)$ (equação 4.14):

$\mathrm{M}_{\mathrm{R}}=\left[\mathrm{O}_{3}\right]_{\text {Residual }} \mathrm{x} \mathrm{V}$

$\mathrm{M}_{\mathrm{C}}=\mathrm{M}_{\mathrm{T}}-\mathrm{M}_{\mathrm{R}}$

O ozônio consumido (C), em termos de concentração, é estimado pela equação 4.15:

$\mathrm{C}(\mathrm{mg} / \mathrm{L})=\mathrm{D}(\mathrm{mg} / \mathrm{L})-\left(\left[\mathrm{O}_{3}\right]_{\text {off-gas }}+\left[\mathrm{O}_{3}\right]_{\text {Residual }}\right)$

D: dosagem de ozônio aplicada, $\mathrm{mg} / \mathrm{L}$;

$\left[\mathrm{O}_{3}\right]_{\text {off-gas }}$ : concentração de ozônio no off-gas, $\mathrm{mg} / \mathrm{L}$ (obtida pela razão entre a massa de ozônio no off-gas e o volume de esgoto desinfetado);

$\left[\mathrm{O}_{3}\right]_{\text {Residual }}$ : concentração de ozônio residual, $\mathrm{mg} / \mathrm{L}$. 
Na Tabela 4.3 encontram-se os valores de CT usados nos ensaios de desinfecção com ozônio.

Tabela 4.3: Valores de ozônio consumido e tempo de contato para se determinar CT.

\begin{tabular}{ccccc}
\hline Experimentos & $\begin{array}{c}\text { Tempo } \\
\text { contato } \\
(\mathrm{min})\end{array}$ & $\begin{array}{c}{\left[\mathrm{O}_{3}\right]_{\mathrm{C}}{ }^{*}} \\
(\mathrm{mg} / \mathrm{L})\end{array}$ & $\begin{array}{c}\text { Taxa de } \\
\text { transferência } \\
(\mathrm{mg} . \mathrm{min} / \mathrm{L})\end{array}$ & $\begin{array}{c}\mathrm{CT} \\
(\mathrm{mg} \cdot \mathrm{min} / \mathrm{L})\end{array}$ \\
\hline 0-A & 10 & 5,33 & 0,53 & 26,7 \\
0-B & $\overline{10}$ & $\overline{5,37}$ & 0,54 & 26,9 \\
I & 10 & 5,03 & 0,25 & 50,3 \\
II & 20 & 4,97 & 0,17 & 74,6 \\
III-A & 30 & 5,28 & 0,18 & 79,2 \\
III-B & 30 & 8,87 & 0,89 & 44,4 \\
IV & 10 & 10,77 & 0,54 & 107,7 \\
V-A & 20 & 10,04 & 0,50 & 100,4 \\
V-B & 20 & 10,42 & 0,35 & 156,3 \\
VI & 30 & 14,37 & 1,44 & 71,8 \\
VII & 10 & 15,46 & 0,77 & 154,6 \\
VIII & 20 & 14,11 & 0,47 & 211,7 \\
IX & 30 & * Concentração de ozônio consumido.
\end{tabular}

\subsubsection{Fase II - Ensaios de desinfecção com radiação UV}

Os ensaios de desinfecção com radiação ultravioleta seguiram o mesmo procedimento descrito no item 4.1.2. A única diferença do efluente ozonizado em relação ao clorado reside no fato de que o primeiro não deixa residual, assim não é necessária essa quantificação após a passagem do efluente pela radiação ultravioleta, e nem se torna necessário o uso de substâncias para remover o ozônio residual, o que por outro lado, é imprescindível para o efluente clorado.

Assim como para o efluente clorado, submetido à radiação UV, foi separada para os exames microbiológicos uma alíquota do efluente ozonizado após a desinfecção com a radiação UV.

\subsection{Exames microbiológicos}

\subsubsection{Exames para determinação de Clostridium perfringens}

A determinação da bactéria formadora de esporos é realizada através de duas etapas consecutivas, a primeira chamada presuntiva e a segunda confirmativa, seguindo o procedimento da norma da CETESB L5.213 (1993) modificada. 
Previamente ao ensaio, devem-se preparar soluções, meios de cultura e esterilizar a vidraria e outros materiais.

Utilizou-se água de diluição, meio de cultura DRCM (meio diferencial enriquecido para clostrídios), meio de cultura Litmus Milk, solução de citrato férrico amoniacal verde a 7 $\%$, solução de sulfito de sódio a 4 \% e vaselina líquida;

A vidraria utilizada foi:

- Balões e béqueres de borossilicato ou vidro neutro com capacidade adequada para o preparo de meios de cultura e água de diluição;

- Frasco de água de diluição de borossilicato ou com tampa que permite boa vedação e seja livre de substâncias tóxicas solúveis, que possa reservar $90 \pm 2 \mathrm{~mL}$ de água de diluição e permita a boa homogeneização quando se fizer a agitação;

- Frasco de plástico autoclavável atóxico;

- Pipetas de borossilicato, tipo Mohr, de 1, 2, 5 e $10 \mathrm{~mL}$;

- Tubos de ensaio de $16 \mathrm{~mm}$ x $150 \mathrm{~mm}$.

Outros materiais usados foram:

- Bico de bunsen;

- Autoclave;

- Banho-maria a $75^{\circ} \mathrm{C}$;

- Estufa a $100{ }^{\circ} \mathrm{C}$;

- Incubadora a $35 \pm 0,5^{\circ} \mathrm{C}$;

- Câmara de UV para esterilizar de vidraria;

- Medidor de $\mathrm{pH}$;

- Estantes para acomodação dos tubos de ensaios empregados na análise;

- Kit de filtração;

- Bomba a vácuo;

- Termômetro;

- Membrana filtrante com $47 \mathrm{~mm}$ de diâmetro e $0,2 \mu \mathrm{m}$ de porosidade, brancas e estéreis.

Nota: O sistema de anaerobiose sugerido pela norma CETESB/L5.213 foi substituído, após a inoculação, pela adição de uma camada com aproximadamente $2 \mathrm{~cm}$ de vaselina líquida autoclavada nos tubos de ensaios. 


\subsubsection{Preparação da água de diluição}

Essa água é usada para preparar as diluições das amostras. As diluições são concentrações preparadas de amostras, cuja finalidade é auxiliar na quantificação dos organismos alvo.

A água de diluição é feita através da combinação de duas soluções, seguindo a mesma norma da CETESB: a solução estoque A e a solução estoque $B$, na seguinte proporção: 1,25 $\mathrm{mL}$ de solução estoque $\mathrm{A}$ e $5 \mathrm{~mL}$ de solução estoque $\mathrm{B}$ para cada $1 \mathrm{~L}$ de água desionizada. Distribuir volumes de $90 \pm 2 \mathrm{~mL}$ em frascos com tampa de rosca, esterilizar em autoclave a $121^{\circ} \mathrm{C}$ durante 15 minutos e armazenar em geladeira até o uso.

A solução estoque A é preparada dissolvendo-se $34 \mathrm{~g}$ de Diidrogênio fosfato de potássio $\left(\mathrm{KH}_{2} \mathrm{PO}_{4}\right)$ para cada $1 \mathrm{~L}$ de água desionizada. Ajusta-se o $\mathrm{pH}$ para 7,2 $\pm 0,5 \mathrm{com}$ solução de hidróxido de sódio $1 \mathrm{~N}$.

A solução estoque B é preparada dissolvendo-se $81,1 \mathrm{~g}$ cloreto de magnésio hexahidratado $\left(\mathrm{MgCl}_{2} \cdot 6 \mathrm{H}_{2} \mathrm{O}\right)$ para cada $1 \mathrm{~L}$ de água desionizada.

\subsubsection{Preparação dos meios de cultura para Clostridium perfringens}

\subsection{Meio diferencial enriquecido para Clostrídios (DRCM)}

O meio DRCM é preparado através da combinação dos componentes descritos na Tabela 4.4.

Tabela 4.4: Composição do meio diferencial enriquecido para Clostridium.

\begin{tabular}{lc}
\hline \multicolumn{1}{c}{ Componentes } & Quantidade \\
\hline Peptona & $10 \mathrm{~g}$ \\
Extrato de carne purificado (em pó) & $10 \mathrm{~g}$ \\
Acetato de sódio hidratado & $5 \mathrm{~g}$ \\
Extrato de levedura & $1,5 \mathrm{~g}$ \\
Amido solúvel & $1,0 \mathrm{~g}$ \\
Glicose & $1,0 \mathrm{~g}$ \\
L- Cisteína & $0,5 \mathrm{~g}$ \\
Água destilada & $1000 \mathrm{~mL}$ \\
\hline
\end{tabular}

O meio DRCM é um meio usado na etapa presuntiva. As bactérias formadoras de esporos reduzem o sulfito que é acrescentando ao meio DRCM formando sulfeto e provocando o enegrecimento do meio. Para preparar o meio DRCM, deve-se dissolver os componentes descritos anteriormente aquecê-los, agitando-os freqüentemente, mas tomando cuidado para que não seja atingida a temperatura de ebulição. Distribuir volumes de $10 \mathrm{~mL}$ 
em tubos de ensaio de $16 \mathrm{~mm}$ x $150 \mathrm{~mm}$, tampar com algodão e esterilizar em autoclave a 121 ${ }^{\circ} \mathrm{C}$ durante 15 minutos. Seu armazenamento deve ser feito em geladeira.

\subsection{Meio de leite tornasssolado}

O meio de leite tornassolado é o meio usado na etapa confirmativa. Nessa fase, os clostrídios sulfito-redutores têm a capacidade de fermentar o leite tornassolado de forma característica, provocando a coagulação do caseinogênio. Essas bactérias, quando inoculadas neste meio de cultura, fermentam a lactose produzindo ácido e gás, o que provoca o rompimento de coágulos.

O método sugerido pela CETESB propõem usar uma composição de leite desnatado e tornassol. No presente trabalho, foi utilizado o meio de cultura Litmus Milk $\mathrm{BBL}^{\mathrm{TM}}$, que exige o uso de $100 \mathrm{~g}$ deste meio para cada $1000 \mathrm{~mL}$ de água destilada. Aquecer essa solução, agitando freqüentemente até a completa dissolução do meio e ter o cuidado para que não seja atingida a temperatura de ebulição. Distribuir volumes de 6 a $7 \mathrm{~mL}$ em tubos de ensaio de 16 $\mathrm{mm}$ x $150 \mathrm{~mm}$. Tamponar e esterilizar em autoclave, a $121{ }^{\circ} \mathrm{C}$ durante 20 minutos. Seu armazenamento deve ser feito em geladeira.

\subsubsection{Preparação de Soluções de citrato férrico amoniacal verde a $7 \%$ e sulfito de sódio $4 \%$}

Solução de citrato férrico amoniacal verde a 7\%: Pesam-se $7 \mathrm{~g}$ de citrato férrico amoniacal verde e dissolve-os em $100 \mathrm{~mL}$ de água desionizada. A esterilização é feita através da filtração com membrana filtrante e com porosidade de $0,2 \mu \mathrm{m}$. Todo o material usado para a filtração e armazenamento da solução foi previamente esterilizado em câmara de UV por 15 minutos. Por fim, a solução preparada é armazenada em frasco rosqueado e em geladeira por no máximo duas semanas.

Solução de sulfito de sódio a 4\%: Pesam-se $4 \mathrm{~g}$ de sulfito de sódio e dissolve-os em $100 \mathrm{~mL}$ de água desionizada. A esterilização e preservação são feitas seguindo o mesmo procedimento descrito para a preparação da solução de citrato férrico amoniacal verde através de filtração.

\subsubsection{Execução do ensaio}

A determinação do número mais provável (NMP) de Clostridium perfringens foi realizada a partir da aplicação da técnica de tubos múltiplos que consiste na inoculação de volumes decrescentes da amostra em meio de cultura adequado ao crescimento dos 
organismos alvo, sendo cada volume inoculado em uma série de 5 tubos. Através de diluições sucessivas da amostra, são obtidos inóculos cuja semeadura fornece resultados negativos em, pelo menos, um tubo da série em que foram inoculados. A combinação de resultados positivos e negativos da fase confirmativa permite a obtenção de uma estimativa da densidade das bactérias pesquisadas através da aplicação de cálculos de probabilidade.

\subsection{Exame presuntivo}

No dia do ensaio, preparam-se as diluições das amostras procedendo da seguinte maneira: nomeia-se cada frasco de água de diluição estéril, anotando-se a amostra e a diluição que deverá conter. Homogeneíza-se a amostra vigorosamente por 30 vezes e com uma pipeta estéril de $10 \mathrm{~mL}$, obedecendo os cuidados de assepsia, transfere-se $10 \mathrm{~mL}$ da amostra para o frasco previamente identificado contendo $90 \pm 2 \mathrm{~mL}$ de água de diluição estéril. Dessa forma, a diluição $10^{-1}$ está preparada.

Repete-se o procedimento descrito acima com o frasco contendo a diluição feita anteriormente $10^{-1}$ e com uma nova pipeta estéril de $10 \mathrm{~mL}$, transfere-se $10 \mathrm{~mL}$ para um novo frasco previamente identificado, contendo $90 \pm 2 \mathrm{~mL}$ de água de diluição estéril. Tem-se então a diluição $10^{-2}$. Da mesma maneira preparam-se as demais diluições desejadas.

As diluições preparadas são aquecidas em banho-maria a $75^{\circ} \mathrm{C}$ por 10 minutos a fim de se remover organismos não esporulados e formas vegetativas.

Antes do seu uso, os tubos de ensaio contendo meio DRCM são aquecidos em béquer contendo água fervente por 10 minutos e resfriados rapidamente em água gelada para remover o ar neles existentes. Após esse choque térmico, deve-se ter o máximo de cuidado para não agitar os tubos evitando assim, reintroduzir oxigênio nos mesmos.

Com as soluções de citrato férrico amoniacal a 7\% e sulfito de sódio $4 \%$, prepara-se uma solução combinando $50 \%$ de ambas as soluções. Com uma pipeta estéril de $2 \mathrm{~mL}$ adiciona-se assepticamente e cuidadosamente para não acrescentar oxigênio nos tubos contendo DRCM, 0,2 mL desta solução a cada tubo de ensaio contendo este meio enriquecido para clostrídios.

Identificam-se e ordenam-se os tubos para inocular as diluições em sequência decrescente (da maior para a menor diluição efetuada), inoculando-se da amostra mais desinfetada para a menos desinfetada.

$\mathrm{Na}$ inoculação, deve-se homogeneizar lentamente as diluições de uma amostra, para evitar a oxigenação. Com o auxílio de uma pipeta estéril de $5 \mathrm{~mL}$, inocula-se $1 \mathrm{~mL}$ da diluição em cada um dos tubos com DRCM correspondentes a essa diluição. Com a mesma pipeta de 5 
$\mathrm{mL}$, inoculam-se as demais diluições da mesma amostra correspondente até finalizar a menor diluição.

Com outra pipeta estéril de $5 \mathrm{~mL}$ faz-se a inoculação de outra amostra seguindo o procedimento do parágrafo anterior.

Após inocular todas as amostras e todas as diluições correspondentes, coloca-se vaselina nestes tubos, formando uma camada de aproximadamente $2 \mathrm{~cm}$ para provocar a diminuição da possibilidade de trocas gasosas entre a amostra inoculada e o ar, como substituição do sistema de anaerobiose proposto na Norma da CETESB/ L5.214 seguida no presente trabalho.

Incubam-se os tubos inoculados a $36{ }^{\circ} \mathrm{C}$ por $48 \mathrm{~h} \pm 3 \mathrm{~h}$.

\subsection{Leitura da fase presuntiva}

Transcorrido o tempo requerido de $48 \mathrm{~h}$, inicia-se a leitura, considerando resultado presuntivo positivo para os tubos que apresentarem enegrecimento ou turvação do meio de cultura.

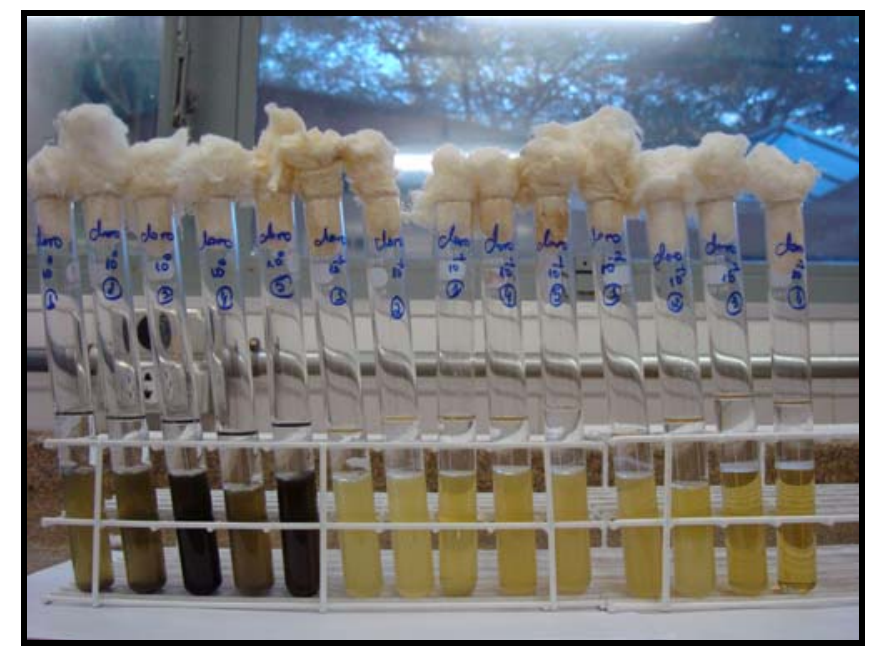

Figura 4.5: Figura ilustrativa dos tubos de DRCM

A Figura 4.5 mostra a variedade de positivos presuntivos possíveis quando a amostra é inoculada no meio DRCM. Os tubos que apresentarem turvação ou enegrecimento após 48h de incubação são considerados positivos presuntivos, cuja confirmação é realizada inoculando-se esses positivos para o meio de cultura Litmus Milk. O negativo é aquele em que o meio DRCM não sofre nenhuma alteração, mantendo-se translúcido (tubo localizado à direita da Figura 4.5). 


\subsection{Exame confirmativo}

Todos os tubos com resultado positivo presuntivo devem ser submetidos à fase confirmativa e os restantes descartados.

$\mathrm{Na}$ fase confirmativa, calcula-se o número de tubos do meio Litmus Milk $\mathrm{BBL}^{\mathrm{TM}}$ a serem utilizados. Esses tubos deverão ser aquecidos por $5 \mathrm{~min}$ em um béquer com água fervente e antes de utilizá-los, é necessário resfriá-los rapidamente em água gelada, para assim remover todo o ar neles presente.

Identificar todos os tubos de Litmus Milk correspondentes respectivamente a cada tubo positivo de DRCM.

São coletados em profundidade $0,1 \mathrm{~mL}$ da cultura positiva de cada tubo de DRCM positivo e passados para o fundo do tubo de Litmus Milk, utilizando-se pipetas estéreis de 1 $\mathrm{mL}$.

Adiciona-se vaselina em cada tubo de Litmus Milk até se obter uma camada de $2 \mathrm{~cm}$ e em seguida, incuba-se esses tubos a $36^{\circ} \mathrm{C}$ por $48 \mathrm{~h} \pm 3 \mathrm{~h}$.

\subsection{Leitura da fase confirmativa}

A leitura é efetuada considerando como tubos positivos confirmativos de Clostridium perfringens aqueles que apresentarem concomitantemente as seguintes características:

- Formação de coágulos (decorrente da coagulação do caseinogênio do leite);

- Acidificação (evidenciada pela coloração rosa do meio de cultura);

- Formação de grande quantidade de gás, causando rompimento dos coágulos (devido à fermentação turbulenta do leite).

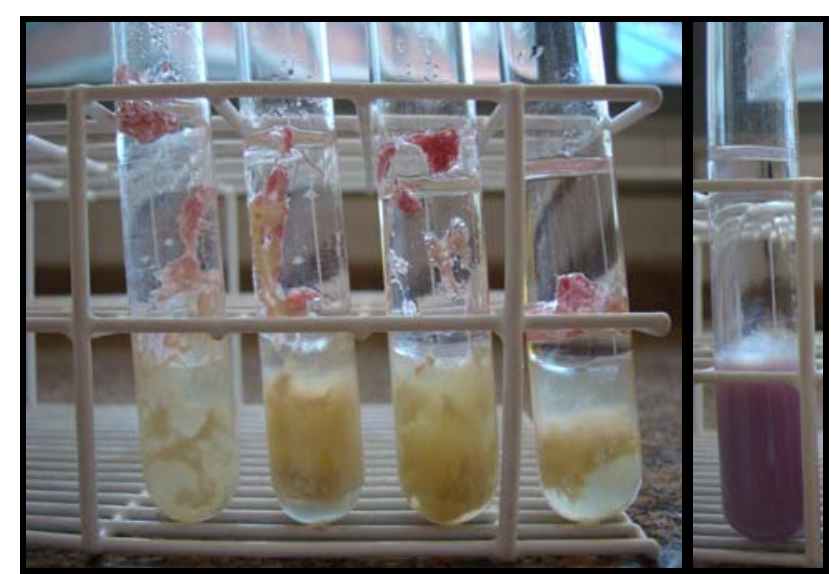

Figura 4.6: Tubos positivos e negativos de C. perfringens 
A Figura 4.6 mostra os resultados positivos confirmativos (os quatro tubos da esquerda para a direita) e um exemplo de tubo negativo (à direita da ilustração) para Clostridium perfringens.

\subsubsection{Cálculo do Número Mais Provável}

A Tabela 4.5 apresenta o número mais provável (NMP) para várias combinações de resultados positivos e negativos, quando são inoculadas cinco porções de $10 \mathrm{~mL}$, cinco porções de $1 \mathrm{~mL}$ e cinco porções de $0,1 \mathrm{~mL}$ da amostra. Para a sua utilização, procuram-se os códigos formados por três algarismos correspondentes ao número de tubos com resultado positivo, no meio confirmativo, em três séries consecutivas inoculadas.

Essa tabela de NMP e os cálculos podem ser usados para exames de coliformes e para a determinação do NMP de outros organismos que adotar a técnica de tubos múltiplos (APHA, 1998). 
Tabela 4.5: NMP e limites de confiança de 95\% para várias combinações de resultados positivos, quando são utilizado cinco tubos por diluição e inóculos de $10 \mathrm{~mL}, 1 \mathrm{~mL}$ e $0,1 \mathrm{~mL}$ (APHA, 1998).

\begin{tabular}{|c|c|c|c|c|c|c|c|}
\hline \multirow{2}{*}{$\begin{array}{l}\text { Número de } \\
\text { combinações } \\
\text { positivas }\end{array}$} & \multirow[t]{2}{*}{$\mathrm{NMP} / 100 \mathrm{~mL}$} & \multicolumn{2}{|c|}{$\begin{array}{l}\text { Limite de } \\
\text { confiança }\end{array}$} & \multirow{2}{*}{$\begin{array}{c}\text { Número de } \\
\text { combinações } \\
\text { positivas }\end{array}$} & \multirow[t]{2}{*}{$\mathrm{NMP} / 100 \mathrm{~mL}$} & \multicolumn{2}{|c|}{$\begin{array}{l}\text { Limite de } \\
\text { confiança }\end{array}$} \\
\hline & & Inf. & Sup. & & & Inf. & Sup. \\
\hline $0-0-0$ & $<2$ & & & $4-2-0$ & 22 & 9 & 56 \\
\hline $0-0-1$ & 2 & $\overline{1}$ & $\overline{10}$ & $4-2-1$ & 26 & 12 & 65 \\
\hline $0-1-0$ & 2 & 1 & 10 & $4-3-0$ & 27 & 12 & 67 \\
\hline \multirow{2}{*}{$0-2-0$} & 4 & 1 & 13 & $4-3-1$ & 33 & 15 & 77 \\
\hline & & & & $4-4-0$ & 34 & 16 & 80 \\
\hline $1-0-0$ & 2 & 1 & 11 & & & & \\
\hline $1-0-1$ & 4 & 1 & 15 & $5-0-0$ & 23 & 9 & 86 \\
\hline $1-1-0$ & 4 & 1 & 15 & $5-0-1$ & 30 & 10 & 110 \\
\hline $1-1-1$ & 6 & 2 & 18 & $5-0-2$ & 40 & 20 & 140 \\
\hline \multirow[t]{3}{*}{$1-2-0$} & 6 & 2 & 18 & $5-1-0$ & 30 & 10 & 120 \\
\hline & & & & $5-1-1$ & 50 & 20 & 150 \\
\hline & & & & $5-1-2$ & 60 & 30 & 180 \\
\hline $2-0-0$ & 4 & 1 & 17 & & & & \\
\hline $2-0-1$ & 7 & 2 & 20 & $5-2-0$ & 50 & 20 & 170 \\
\hline $2-1-0$ & 7 & 2 & 21 & $5-2-1$ & 70 & 30 & 210 \\
\hline $2-1-1$ & 9 & 3 & 24 & $5-2-2$ & 90 & 40 & 250 \\
\hline $2-2-0$ & 9 & 3 & 25 & $5-3-0$ & 80 & 30 & 250 \\
\hline \multirow{2}{*}{$2-3-0$} & 12 & 5 & 29 & $5-3-1$ & 110 & 40 & 300 \\
\hline & & & & $5-3-2$ & 140 & 60 & 360 \\
\hline $3-0-0$ & 8 & 3 & 24 & $5-3-3$ & 170 & 80 & 410 \\
\hline $3-0-1$ & 11 & 4 & 29 & $5-4-0$ & 130 & 50 & 390 \\
\hline $3-1-0$ & 11 & 4 & 29 & $5-4-1$ & 170 & 70 & 480 \\
\hline $3-1-1$ & 14 & 6 & 35 & $5-4-2$ & 220 & 100 & 580 \\
\hline $3-2-0$ & 14 & 6 & 35 & $5-4-3$ & 280 & 120 & 690 \\
\hline \multirow[t]{2}{*}{$3-2-1$} & 17 & 7 & 40 & $5-4-4$ & 350 & 160 & 820 \\
\hline & & & & $5-5-0$ & 240 & 100 & 940 \\
\hline $4-0-0$ & 13 & 5 & 38 & $5-5-1$ & 300 & 100 & 1300 \\
\hline $4-0-1$ & 17 & 7 & 45 & $5-5-2$ & 500 & 200 & 2000 \\
\hline $4-1-0$ & 17 & 7 & 46 & $5-5-3$ & 900 & 300 & 2900 \\
\hline $4-1-1$ & 21 & 9 & 55 & $5-5-4$ & 1600 & 600 & 5300 \\
\hline $4-1-2$ & 26 & 12 & 63 & $5-5-5$ & $\geq 1600$ & & \\
\hline
\end{tabular}

No caso em que são utilizados os mesmos volumes de amostra apresentados na Tabela 4.5, o NMP é obtido diretamente da mesma. Quando são utilizados volumes decimais diferentes do volume de amostra, procura-se o código formado pelos tubos positivos obtidos em três séries consecutivas inoculadas, utilizado-se o valor de NMP correspondente a sua série de diluições. O NMP em $100 \mathrm{~mL}$ é obtido utilizando-se a equação (4.16):

$\mathrm{NMP} / 100 \mathrm{~mL}=\mathrm{NMP}$ correspondente ao código $\mathrm{x}$ (10/ maior volume inoculado). 
Quando são inoculados mais de três volumes decimais, são utilizados para a composição do código apenas os resultados positivos correspondentes a três séries consecutivas inoculadas, sendo que o primeiro algarismo escolhido para compor o código será correspondente ao tubo de maior volume da amostra, devendo ser utilizada a equação (4.16) para o cálculo de NMP.

A Tabela 4.5 mostra a combinação dos tubos positivos mais comuns. O NMP para combinações que não aparecem nessa tabela pode ser estimado através da fórmula de Thomas (APHA, 1998) (equação 4.17).

$$
N M P / 100 m L=\frac{\text { númerode tubospositivosx } 10}{\sqrt{(\text { mLde amostranos tubosnegativosx mLde amostraem todos os tubos })}}
$$

\subsubsection{Exames para determinação de coliformes totais e Escherichia coli}

Para a quantificação de $E$. coli foi utilizada a técnica de filtração em membranas usando-se o meio Chromocult ${ }^{\circledR}$ Coliform Agar (Merck Cat.No.1.10426) que determina simultaneamente a presença de coliformes totais e E. coli.

É necessário dizer que este meio de cultura não é autoclavável, exigindo-se então um cuidado especial para evitar a contaminação do mesmo, portanto, toda a vidraria e a bancada devem ser esterilizadas antes de sua preparação.

O material usado para preparar o meio de cultura Chromocult ${ }^{\circledR}$ Coliform Agar é:

- Béqueres de borossilicato;

- Placas de Petri de 90 x 15;

- Frascos com rosca para preparar água de diluição seguindo item 4.3.1.1;

- Pipeta de 10 mL estéril;

- Panela para promover banho-maria;

- Bico de Bunsen;

- Bastão de vidro;

- Pinça;

- Kit de filtração;

- Membrana de nitrocelulose de 0,45 $\mu \mathrm{m}$ de porosidade e $47 \mathrm{~mm}$ de diâmetro;

- Ebulidor para esterilizar o kit de filtração.

\subsubsection{Preparação do meio de cultura Chromocult ${ }^{\circledR}$}

Utiliza-se $10 \mathrm{~mL}$ de meio de cultura por placa. Calcula-se o número de placas que se deseja preparar. Pesa-se a massa necessária para o número de placas requerido e dissolve-se o 
meio em água desionizada na proporção de 26,5 g de Chromocult® para cada $1 \mathrm{~L}$ de água desionizada.

Prepara-se um banho-maria utilizando-se o bico de Bunsen até atingir o ponto de ebulição da água. Atingindo a fervura, dispõe-se o béquer com meio de cultura no banhomaria e agita-se repetidamente com o auxílio de um bastão de vidro, por 30 minutos. Retira-se o meio de cultura do fogo e coloca-se $10 \mathrm{~mL}$ de meio em cada placa de Petri, deixando-o esfriar e endurecer por pelo menos 30 minutos para então armazená-lo em geladeira até o seu uso.

\subsubsection{Preparação das diluições}

A água de diluição é preparada seguindo o item 4.3.1.1. As diluições procedem da seguinte maneira: nomeia-se cada frasco de água de diluição estéril, anotando-se a amostra e a diluição que deverá conter. Cada diluição é feita em duplicata a fim de que uma das réplicas seja utilizada na preparação da diluição conseguinte e a outra utilizada para conter $100 \mathrm{~mL}$ totais, ou seja, $90 \mathrm{~mL}$ da água de diluição e $10 \mathrm{~mL}$ de amostra.

Na diluição, homogeneíza-se a amostra vigorosamente por 30 vezes. Com uma pipeta estéril de $10 \mathrm{~mL}$, obedecendo aos cuidados de assepsia, transfere-se $10 \mathrm{~mL}$ da amostra para dois frascos previamente identificados contendo $90 \pm 2 \mathrm{~mL}$ de água de diluição estéril. Assim a diluição $10^{-1}$ está preparada. Com uma das réplicas e com o auxílio de uma nova pipeta estéril de $10 \mathrm{~mL}$, transfere-se $10 \mathrm{~mL}$ da diluição $10^{-1}$ para dois novos frascos previamente identificados, contendo $90 \pm 2 \mathrm{~mL}$ de água de diluição estéril. Tem-se então a diluição $10^{-2}$. Da mesma maneira preparam-se as demais diluições desejadas.

\subsubsection{Execução do ensaio}

Para o teste, o volume de $100 \mathrm{~mL}$ de amostra ou diluição são filtrados em membrana estéril de porosidade 0,45 $\mu \mathrm{m}$ e $47 \mathrm{~mm}$ de diâmetro da marca Gelman GN-6. Sugere-se fazer a filtragem da amostra mais desinfetada e mais diluída para a menos desinfetada e menos diluída para evitar a contaminação. No espaço de tempo entre as filtrações, sugere-se também que se faça a esterilização do kit de filtração e da pinça utilizando água fervente (promovida por um ebulidor). Após a filtração, as membranas são colocadas em placas de Petri contendo o referido meio e incubadas a $36 \pm 1^{\circ} \mathrm{C}$ por $24 \pm 1 \mathrm{~h}$.

Ao transferir a membrana para a superfície do meio de cultura, é necessário observar que toda a sua área deve ficar completamente aderida ao meio, podendo realizar movimentos 
giratórios utilizando a pinça fora da área de filtração até a completa adesão da membrana no meio de cultura.

Nessa técnica, as colônias que apresentarem coloração salmão / vermelha são reconhecidas como coliformes totais e coloração azul-escura / violeta como E. coli. Na contagem dos coliformes totais devem-se incluir as unidades formadoras de colônias de $E$. coli. Os resultados devem ser expressos em UFC/100 mL.

\subsubsection{Leitura}

Na Figura 4.7 é possível observar colônias azuis na porção central da fotografia, representando colônias de E. coli, e outras colônias de tom rosado por toda a extensão da foto, representando as bactérias coliformes totais, as quais a sua totalidade é conferida pela soma da parcela de E. coli. As colônias amarelas e brancas não são contadas, pois não correspondem às bactérias coliformes totais.

Consideram-se as bactérias E. coli aquelas de coloração azul escura. Para a sua confirmação poder-se-ia realizar exames bioquímicos, mas no escopo deste trabalho, esses exames não foram realizados.

O resultado é expresso em unidades formadoras de colônia por $100 \mathrm{~mL}$ de amostra (UFC/100mL). Para compor o resultado, basta fazer a contagem da placa; o número de colônias existentes nessa placa é multiplicado pelo valor do inverso da diluição correspondente. Por exemplo: ocorre o desenvolvimento de 30 colônias em uma placa correspondente a diluição de $10^{-3}$, então o resultado é igual a $30 \times 10^{3}=3 \times 10^{4} \mathrm{UFC} / 100 \mathrm{~mL}$.

É sugerido incubar mais de uma diluição de uma mesma amostra a fim de se ter resultados possíveis de serem quantificados. Caso mais de uma diluição seja usada, o que é preferível, seleciona-se o resultado da menor diluição a fim de se evitar erros inerentes ao processo de diluição. 


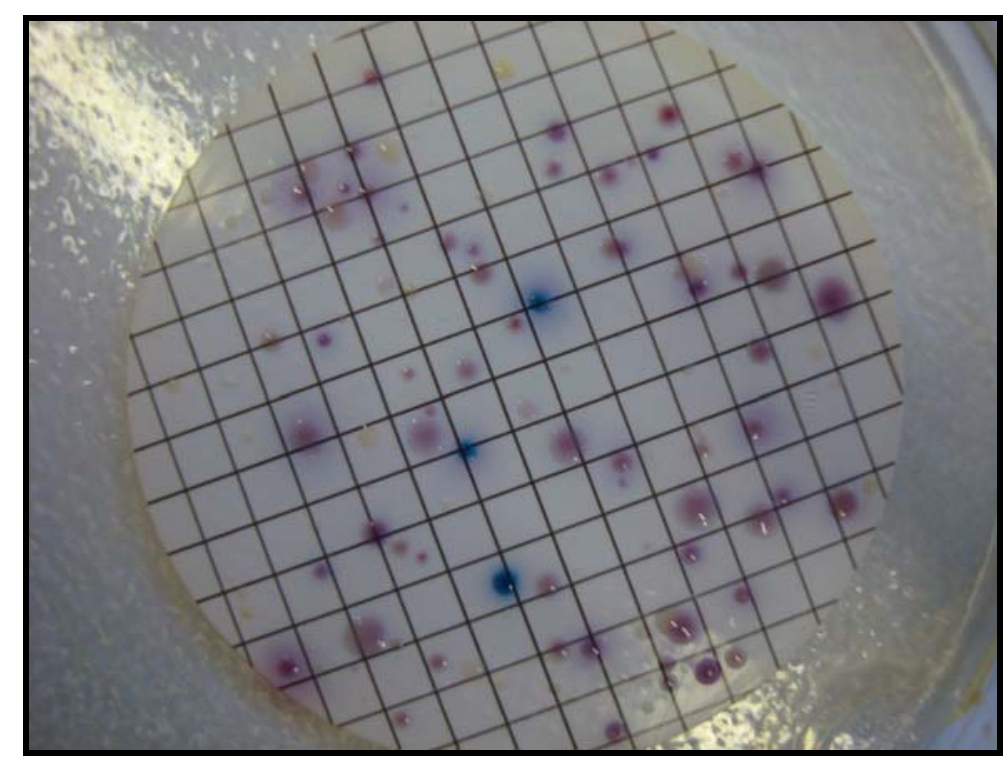

Figura 4.7: Representação do crescimento de colônias no meio Chromocult Coliform Agar®

Os métodos analíticos empregados para a realização das analises e exames, bem como os equipamentos usados na pesquisa, estão sumarizados na Tabela 4.6.

Tabela 4.6: Métodos analíticos, exames, análises e equipamentos empregados nos ensaios de desinfecção.

\begin{tabular}{ll}
\hline \multicolumn{1}{c}{ Parâmetros } & \multicolumn{1}{c}{ Descrição do Método } \\
\hline $\begin{array}{l}\text { Cloro residual livre e } \\
\text { total }\end{array}$ & $\begin{array}{l}\text { Método DPD colorimétrico, com utilização de Kit da HACK e } \\
\text { leitura em espectrofotômetro DR 2010 }\end{array}$ \\
\hline & $\begin{array}{l}\text { Método Iodométrico (titulometria) e método colorimétrico, com } \\
\text { Ozônio residual }\end{array}$ \\
& DT 11 e reagentes da Merck (Chlor test. Cat. No. 1.14803.001 \\
\hline
\end{tabular}

\begin{tabular}{ll}
\hline Alcalinidade Total & Titulação potenciométrica com ácido sulfúrico, APHA (1998) \\
\hline $\mathrm{pH}$ & Potenciométrico \\
\hline Temperatura & Termômetro de mercúrio \\
\hline $\begin{array}{l}\text { Absorbância em } \\
\text { comprimento de onda de }\end{array}$ & Espectrofotômetro DR 4000 \\
$254 \mathrm{~nm}$ &
\end{tabular}

Nitrogênio amoniacal Análise por Injeção em Fluxo, APHA(1998)

Sólidos Suspensos

Totais e Sólidos Totais

Método Gravimétrico, APHA(1998)

Demanda Química de Oxigênio (DQO)

Método colorimétrico em Refluxo Fechado, APHA(1998)

E. coli e coliformes Técnica de filtração em membranas usando meio Chromocult ${ }^{\circledR}$ totais Coliform Agar (Merck Cat. No. 1.10426)

Clostridium perfringens Técnica de Tubos múltiplos. Norma CETESB L5.213/93

Os resultados foram expresso em tabelas e gráficos realizados por meio do Software Excel nas versões 2003 e 2007. 
Para calcular a eficiência de remoção e o log de inativação dos dados microbiológicos foram usadas as equações 4.18 e 4.19 .

$E f(\%)=\frac{N_{o}-N}{N_{o}} x 100$

$\log ($ inativação $)=-\log _{10}\left(\frac{N}{N o}\right)$

(4.19)

Ef (\%): eficiência de inativação;

$\mathrm{N}$ : UFC/100mL (E. coli e c. totais) e NMP/100mL (C. perfringens) para $\mathrm{t}>0$;

No: UFC/100mL (E. coli e c. totais) e NMP/100mL (C. perfringens) para $\mathrm{t}=0$.

$\mathrm{Na}$ Tabela 4.7 estão apresentadas as equações referentes à cinética de inativação de microrganismos.

Tabela 4.7: Equações de cinética de inativação de microrganismos exploradas no presente trabalho:

\begin{tabular}{l|l|l}
\hline & Watson modificado & Hom \\
\hline Para cloro & $\frac{N}{N_{o}}=\exp \left(-K^{\prime} C_{\text {aplicado }}{ }^{n} t\right)$ & $\frac{N}{N_{o}}=\exp \left(-K^{\prime} C_{\text {aplicado }}{ }^{n} t^{m}\right)$ \\
\hline $\begin{array}{c}N o \\
\text { Para ozônio }\end{array}$ & $\begin{array}{l}\text { Na qual CT é calculado conforme } \\
\text { o item 3.6.3 }\end{array}$ & \\
\hline $\begin{array}{l}\text { Para Ozônio } \\
\text { seguido de UV; } \\
\begin{array}{l}\text { Cloro seguido de } \\
\text { UV; e UV. }\end{array}\end{array}$ & $\frac{N}{N o}=\exp \left(-K D_{r}{ }^{n}\right)$ & \\
\hline
\end{tabular}

No presente trabalho, testes foram feitos para obter o melhor ajuste de equações aos resultados experimentais.

Para a desinfecção sequencial, tanto do cloro seguido de UV, quanto do ozônio seguido de UV, foi usada a variável dose recebida de radiação $\left(D_{r}\right)$ em $W h / m^{3}$, em vez da composição de intensidade multiplicada pelo tempo ( $\mathrm{I}$ x t), a intensidade é expressa em $\mathrm{mW} / \mathrm{cm}^{2}$ e o tempo em segundo (s). A concentração de cloro e a de ozônio na desinfecção sequencial correspondeu à dose zero de UV. 


\section{Resultados e Discussão}

Optou-se por apresentar separadamente os resultados dos experimentos de desinfecção com cloro e com ozônio para posteriormente finalizar a discussão com a comparação entre as inferências geradas por ambos os desinfetantes.

\subsection{Ensaios de desinfecção com cloro seguido de radiação ultravioleta}

A caracterização físico-química e microbiológica do efluente anaeróbio bruto e do clorado foi realizada medindo-se: o $\mathrm{pH}$, a temperatura, a alcalinidade total, sólidos totais, sólidos suspensos totais, nitrogênio amoniacal, cloro residual livre e total após a cloração; exames de Escherichia coli, coliformes totais e Clostridium perfringens. Para o efluente clorado submetido à desinfecção com radiação UV, foram feitos apenas os exames microbiológicos e quantificação de cloro residual livre e total do ensaio no qual se aplicou a maior dose de radiação UV.

Estão apresentados na Tabela 5.1 as características do esgoto bruto e do efluente ao reator UASB de acordo com PASSIG, 2005. Destacam-se os parâmetros analisados para caracterizar o efluente desse reator utilizado como amostra para os experimentos de desinfecção.

Tabela 5.1: Alguns parâmetros de caracterização do esgoto bruto ao reator UASB e efluente a esse reator (PASSIG, 2005)

\begin{tabular}{lcc}
\hline Parâmetros & Esgoto Bruto & Efluente $_{\text {UASB }}$ \\
\hline & \multicolumn{2}{c}{ média \pm desvio padrão } \\
DQO (mg/L) & $566 \pm 216$ & $183 \pm 152$ \\
Sólidos Totais $(\mathrm{mg} / \mathrm{L})$ & $557 \pm 310$ & $388 \pm 127$ \\
Sólidos Suspensos Totais $(\mathrm{mg} / \mathrm{L})$ & $121 \pm 75$ & $82 \pm 76$ \\
\hline
\end{tabular}

Fonte: PASSIG, 2005 apud SILVA ${ }^{14}, 2008$.

O reator em si, sua operação e processos não foram objetos do presente estudo. $O$ Efluente desse reator que foi a amostra submetida a desinfecção.

Nas Tabelas 5.2 a 5.10 está apresentada a caracterização físico-química e microbiológica do efluente bruto e desinfetado obtida nos ensaios de desinfecção com cloro seguido de UV.

Efluente bruto (EB) é o termo dado à amostra inicial do sistema de desinfecção, proveniente da saída do reator UASB da ETE-USP-SC, o qual ainda não está desinfetado. O

14 SILVA, G. H. P. Formação de aldeídos e trialometanos da desinfecção por ozonização, cloração e ozonização/cloração de efluente de tratamento anaeróbio de esgoto sanitário. 401 p. Tese (Doutorado)- Escola de Engenharia de São Carlos, Universidade de São Paulo, São Carlos, (2008). 
efluente clorado (EC) é o termo dado ao efluente do reator UASB que sofreu cloração para uma dada concentração de cloro e um determinado tempo de contato. EUV é a sigla para denominar o efluente clorado que foi submetido à radiação UV, sendo que os índices 1,2 e 3 referem-se à primeira, segunda e terceira dose de radiação utilizadas.

Tabela 5.2: Características físico-químicas e microbiológicas do esgoto no experimento I.

\begin{tabular}{|c|c|c|c|c|c|c|c|c|}
\hline \multirow[b]{2}{*}{ Variáveis } & \multicolumn{5}{|c|}{ Experimento I-A $(9,28 ; 10)^{(1)}$} & \multicolumn{3}{|c|}{ I-B (somente UV) } \\
\hline & $\mathrm{EB}^{(2)}$ & $\mathrm{EC}^{(3)}$ & $\begin{array}{c}\mathrm{EUV}_{1}{ }^{(4)} \\
\left(1 \mathrm{Wh} / \mathrm{m}^{3}\right)\end{array}$ & $\begin{array}{c}\mathrm{EUV}_{2}{ }^{(5)} \\
\left(5 \mathrm{Wh} / \mathrm{m}^{3}\right)\end{array}$ & $\begin{array}{c}\mathrm{EUV}_{3}{ }^{(6)} \\
\left(10 \mathrm{Wh} / \mathrm{m}^{3}\right)\end{array}$ & $\begin{array}{c}\operatorname{EUV}_{1} \\
\text { sem cloro } \\
\left(1 \mathrm{Wh} / \mathrm{m}^{3}\right)\end{array}$ & $\begin{array}{c}\operatorname{EUV}_{2 \text { sem }} \\
\text { cloro } \\
\left(5 \mathrm{Wh} / \mathrm{m}^{3}\right)\end{array}$ & $\begin{array}{c}\operatorname{EUV}_{3} \\
\text { sem cloro } \\
\left(10 \mathrm{Wh} / \mathrm{m}^{3}\right)\end{array}$ \\
\hline $\mathrm{T}\left({ }^{\circ} \mathrm{C}\right)$ & 22,5 & 22,5 & & & & & & \\
\hline $\mathrm{pH}$ & 6,35 & 5,6 & 5,71 & 5,83 & 5,66 & 6,37 & 6,45 & 6,51 \\
\hline $\begin{array}{l}\text { Alcalinidade } \\
\text { Total } \\
\left(\mathrm{mgCaCO}_{3} / \mathrm{L}\right)\end{array}$ & 187 & 115 & & & & & & \\
\hline $\mathrm{ST}(\mathrm{mg} / \mathrm{L})$ & 260 & 423 & & & & & & \\
\hline $\mathrm{SST}(\mathrm{mg} / \mathrm{L})$ & 44 & 28 & & & & & & \\
\hline DQO (mg/L) & 247 & 350 & & & & & & \\
\hline $\mathrm{N}-\mathrm{NH}_{3}(\mathrm{mg} / \mathrm{L})$ & 20 & 20 & & & & & & \\
\hline $\begin{array}{l}\text { Cloro residual } \\
\text { livre }(\mathrm{mgCl} / \mathrm{L})\end{array}$ & & $0,31^{(1}$ & & & $0,79^{(12)}$ & & & \\
\hline $\begin{array}{l}\text { Cloro residual } \\
\text { total }(\mathrm{mgCl} / \mathrm{L})\end{array}$ & & $\begin{array}{l}4,51^{(1} \\
1)\end{array}$ & & & $3,29^{(13)}$ & & & \\
\hline $\begin{array}{l}\text { E. coli } \\
\text { (UFC/100mL) }\end{array}$ & $8 \times 10^{5}$ & $6 \times 10^{3}$ & $2 \times 10^{2}$ & $9 \times 10^{1}$ & $7 \times 10^{1}$ & $1 \times 10^{3}$ & $4 \times 10^{2}$ & $4 \times 10^{2}$ \\
\hline $\begin{array}{l}\text { Coliformes } \\
\text { totais } \\
\text { (UFC/100mL) }\end{array}$ & $1,5 \times 10^{7}$ & $7 \times 10^{3}$ & $3,8 \times 10^{2}$ & $1,1 \times 10^{2}$ & $1,1 \times 10^{2}$ & $2,6 \times 10^{3}$ & $1,6 \times 10^{3}$ & $7 \times 10^{2}$ \\
\hline $\begin{array}{l}\text { C. perfringens } \\
(\mathrm{NMP} / 100 \mathrm{~mL})\end{array}$ & $5 \times 10^{3}$ & $5 \times 10^{3}$ & $3 \times 10^{2}$ & $4 \times 10^{1}$ & $2 \times 10^{1}$ & $3,5 \times 10^{3}$ & $7 \times 10^{2}$ & $2,2 \times 10^{2}$ \\
\hline
\end{tabular}

Notas: (1) concentração de cloro aplicada $\left(\mathrm{mgCl}_{2} / \mathrm{L}\right)$, tempo de contato (min); (2) efluente bruto; (3) efluente clorado; (4) efluente clorado submetido à primeira dose de UV; (5) efluente clorado submetido à segunda dose de UV; (6) efluente clorado submetido à terceira dose de UV; (7) efluente do reator UASB submetido à primeira dose de UV; (8) efluente do reator UASB submetido à segunda dose de UV; (9) efluente do reator UASB submetido à terceira dose de UV; concentração residual de cloro livre (10) e total (11) após ensaio com cloro; concentração residual de cloro livre (12) e total (13) após ensaio com UV. 
Tabela 5.3: Características físico-químicas e microbiológicas do esgoto no experimento II.

Experimento II $(9,6 ; 20)^{(1)}$

Variáveis $\quad \begin{array}{lllll}\mathrm{EB}^{(2)} & \mathrm{EC}^{(3)} & \begin{array}{c}\mathrm{EUV}_{1}^{(4)} \\ \left(1 \mathrm{Wh} / \mathrm{m}^{3}\right)\end{array} & \begin{array}{c}\mathrm{EUV}_{2}{ }^{(5)} \\ \left(5 \mathrm{Wh} / \mathrm{m}^{3}\right)\end{array} & \begin{array}{c}\mathrm{EUV}_{3}^{(6)} \\ \left(10 \mathrm{Wh} / \mathrm{m}^{3}\right)\end{array}\end{array}$

\begin{tabular}{|c|c|c|c|c|c|}
\hline $\mathrm{T}\left({ }^{\circ} \mathrm{C}\right)$ & 22 & 22 & & & \\
\hline $\mathrm{pH}$ & 6,38 & 5,57 & 5,79 & 5,7 & 5,88 \\
\hline Alcalinidade Total $\left(\mathrm{mgCaCO}_{3} / \mathrm{L}\right)$ & 197 & 151 & & & \\
\hline $\mathrm{ST}(\mathrm{mg} / \mathrm{L})$ & 393 & 436 & & & \\
\hline SST (mg/L) & 88 & 79 & & & \\
\hline DQO (mg/L) & 371 & 671 & & & \\
\hline $\mathrm{N}-\mathrm{NH}_{3}(\mathrm{mg} / \mathrm{L})$ & 23 & 19 & & & \\
\hline Cloro residual livre $\left(\mathrm{mgCl}_{2} / \mathrm{L}\right)$ & & $0,14^{(7)}$ & & & $0,2^{(9)}$ \\
\hline Cloro residual total $\left(\mathrm{mgCl}_{2} / \mathrm{L}\right)$ & & $1,32^{(8)}$ & & & $0,48^{(10)}$ \\
\hline E. coli $(\mathrm{UFC} / 100 \mathrm{~mL})$ & $4 \times 10^{5}$ & $<1$ & $<1$ & $<1$ & $<1$ \\
\hline Coliformes totais (UFC/100mL) & $5 \times 10^{6}$ & $5,1 \times 10^{2}$ & $6,2 \times 10^{2}$ & $2 \times 10^{2}$ & $1 \times 10^{2}$ \\
\hline C. perfringens (NMP/100mL) & $5 \times 10^{3}$ & $1,4 \times 10^{3}$ & $1,3 \times 10^{3}$ & $4 \times 10^{1}$ & $2 \times 10^{1}$ \\
\hline
\end{tabular}

Notas: (1) concentração de cloro aplicada $\left(\mathrm{mgCl}_{2} / \mathrm{L}\right)$, tempo de contato (min); (2) efluente bruto; (3) efluente clorado; (4) efluente clorado submetido à primeira dose de UV; (5) efluente clorado submetido à segunda dose de UV; (6) efluente clorado submetido à terceira dose de UV; concentração residual de cloro livre (7) e total (8) após ensaio com cloro; concentração residual de cloro livre (9) e total (10) após ensaio com UV.

Tabela 5.4: Características físico-químicas e microbiológicas do esgoto no experimento III.

$$
\text { Experimento III }(9,36 ; 30)^{(1)}
$$

\begin{tabular}{|c|c|c|c|c|c|}
\hline Variáveis & $\mathrm{EB}^{(2)}$ & $\mathrm{EC}^{(3)}$ & $\begin{array}{l}\mathrm{EUV}_{1}^{(4)} \\
\left(1 \mathrm{Wh} / \mathrm{m}^{3}\right)\end{array}$ & $\begin{array}{l}\mathrm{EUV}_{2}{ }^{(5)} \\
\left(5 \mathrm{Wh} / \mathrm{m}^{3}\right)\end{array}$ & $\begin{array}{c}\mathrm{EUV}_{3}{ }^{(6)} \\
\left(10 \mathrm{Wh} / \mathrm{m}^{3}\right)\end{array}$ \\
\hline $\mathrm{T}\left({ }^{\circ} \mathrm{C}\right)$ & 22,5 & 22 & & & \\
\hline $\mathrm{pH}$ & 6,78 & 5,62 & 6,12 & 6,02 & 6,02 \\
\hline Alcalinidade Total $\left(\mathrm{mgCaCO}_{3} / \mathrm{L}\right)$ & 194 & 142 & & & \\
\hline $\mathrm{ST}(\mathrm{mg} / \mathrm{L})$ & 279 & 373 & & & \\
\hline SST (mg/L) & 40 & 80 & & & \\
\hline DQO $(\mathrm{mg} / \mathrm{L})$ & 312 & 469 & & & \\
\hline $\mathrm{N}-\mathrm{NH}_{3}(\mathrm{mg} / \mathrm{L})$ & 6,83 & $0^{(7)}$ & & & \\
\hline Cloro residual livre $\left(\mathrm{mgCl}_{2} / \mathrm{L}\right)$ & & $0,31^{(8)}$ & & & $0,83^{(10)}$ \\
\hline Cloro residual total $\left(\mathrm{mgCl}_{2} / \mathrm{L}\right)$ & & $4,72^{(9)}$ & & & $2,9^{(11)}$ \\
\hline E. coli $(\mathrm{UFC} / 100 \mathrm{~mL})$ & $3 \times 10^{5}$ & $<1$ & $<1$ & $<1$ & $<1$ \\
\hline Coliformes totais $(\mathrm{UFC} / 100 \mathrm{~mL})$ & $1,4 \times 10^{7}$ & $1 \times 10^{3}$ & $7 \times 10^{2}$ & $1 \times 10^{2}$ & $2 \times 10^{2}$ \\
\hline C. perfringens $(\mathrm{NMP} / 100 \mathrm{~mL})$ & $3 \times 10^{3}$ & $5 \times 10^{3}$ & $2,6 \times 10^{2}$ & $2,3 \times 10^{2}$ & $2,3 \times 10^{2}$ \\
\hline
\end{tabular}

Notas: (1) concentração de cloro aplicada $\left(\mathrm{mgCl}_{2} / \mathrm{L}\right)$, tempo de contato (min); (2) efluente bruto; (3) efluente clorado; (4) efluente clorado submetido à primeira dose de UV; (5) efluente clorado submetido à segunda dose de UV; (6) efluente clorado submetido à terceira dose de UV; (7) valor abaixo do limite de detecção do equipamento; concentração residual de cloro livre (8) e total (9) após ensaio com cloro; concentração residual de cloro livre (10) e total (11) após ensaio com UV. 
Tabela 5.5: Características físico-químicas e microbiológicas do esgoto no experimento IV.

Experimento IV $(22,5 ; 10)^{(1)}$

\begin{tabular}{|c|c|c|c|c|}
\hline Variáveis & $\mathrm{EB}^{(2)}$ & $\mathrm{EC}^{(3)}$ & $\begin{array}{c}\mathrm{EUV}_{1}^{(4)} \\
\left(1 \mathrm{Wh} / \mathrm{m}^{3}\right)\end{array}$ & $\begin{array}{c}\mathrm{EUV}_{2}^{(5)} \\
\left(5 \mathrm{Wh} / \mathrm{m}^{3}\right)\end{array}$ \\
\hline
\end{tabular}

\begin{tabular}{lccccc}
\hline $\mathrm{T}\left({ }^{\circ} \mathrm{C}\right)$ & 26 & 26 & & & \\
$\mathrm{pH}$ & 6,53 & 6,58 & 6,23 & 6,44 & 6,34 \\
Alcalinidade Total $\left(\mathrm{mgCaCO}_{3} / \mathrm{L}\right)$ & 142 & 136 & & & \\
$\mathrm{ST}(\mathrm{mg} / \mathrm{L})$ & 332 & 439 & & & \\
$\mathrm{SST}(\mathrm{mg} / \mathrm{L})$ & 70 & 38 & & & \\
$\mathrm{DQO}(\mathrm{mg} / \mathrm{L})$ & 252 & 306 & & & \\
$\mathrm{~N}^{\mathrm{NH}} \mathrm{H}_{3}(\mathrm{mg} / \mathrm{L})$ & 22 & 18 & & & $1,38^{(9)}$ \\
Cloro residual livre $\left(\mathrm{mgCl}_{2} / \mathrm{L}\right)$ & & $0,9^{(7)}$ & & & $10,14^{(10)}$ \\
Cloro residual total $\left(\mathrm{mgCl}_{2} / \mathrm{L}\right)$ & & $15,76^{(8)}$ & & & $<1$ \\
E. coli $(\mathrm{UFC} / 100 \mathrm{~mL})$ & $3 \times 10^{6}$ & $<1$ & $<1$ & $<1$ & $1 \times 10^{0}$ \\
Coliformes totais $(\mathrm{UFC} / 100 \mathrm{~mL})$ & $2,3 \times 10^{7}$ & $4 \times 10^{2}$ & $4 \times 10^{1}$ & $3 \times 10^{1}$ & $4 \times 10^{1}$ \\
C. perfringens $(\mathrm{NMP} / 100 \mathrm{~mL})$ & $1,3 \times 10^{4}$ & $1,1 \times 10^{3}$ & $4 \times 10^{1}$ & $2 \times 10^{1}$ & \\
\hline
\end{tabular}

Notas: (1) concentração de cloro aplicada $\left(\mathrm{mgCl}_{2} / \mathrm{L}\right.$ ), tempo de contato $(\mathrm{min})$; (2) efluente bruto; (3) efluente clorado; (4) efluente clorado submetido à primeira dose de UV; (5) efluente clorado submetido à segunda dose de UV; (6) efluente clorado submetido à terceira dose de UV; concentração residual de cloro livre (7) e total (8) após ensaio com cloro; concentração residual de cloro livre (9) e total (10) após ensaio com UV.

Tabela 5.6: Características físico-químicas e microbiológicas do esgoto no experimento $\mathrm{V}$.

$$
\text { Experimento V }(22,48 ; 20)^{(1)}
$$

\begin{tabular}{lccccc}
\multicolumn{1}{c}{ Variáveis } & $\mathrm{EB}^{(2)}$ & $\mathrm{EC}^{(3)}$ & $\begin{array}{c}\mathrm{EUV}_{1}{ }^{(4)} \\
\left(1 \mathrm{Wh} / \mathrm{m}^{3}\right)\end{array}$ & $\begin{array}{c}\mathrm{EUV}_{2}{ }^{(5)} \\
\left(5 \mathrm{Wh} / \mathrm{m}^{3}\right)\end{array}$ & $\begin{array}{c}\mathrm{EUV}_{3}{ }^{(6)} \\
\left(10 \mathrm{Wh} / \mathrm{m}^{3}\right)\end{array}$ \\
\hline $\mathrm{T}\left({ }^{\circ} \mathrm{C}\right)$ & 25,5 & 25 & & & \\
$\mathrm{pH}$ & 6,39 & 5,85 & 5,86 & 6,13 & 5,98 \\
Alcalinidade Total $\left(\mathrm{mgCaCO}_{3} / \mathrm{L}\right)$ & 130 & 97 & & & \\
$\mathrm{ST}(\mathrm{mg} / \mathrm{L})$ & 466 & 588 & & & \\
$\mathrm{SST}(\mathrm{mg} / \mathrm{L})$ & 147 & 134 & & & \\
$\mathrm{DQO}(\mathrm{mg} / \mathrm{L})$ & 452 & 454 & & & $0,52^{(9)}$ \\
$\mathrm{N}-\mathrm{NH}{ }_{3}(\mathrm{mg} / \mathrm{L})$ & 15 & 13 & & & $4,01^{(10)}$ \\
Cloro residual livre $\left(\mathrm{mgCl}_{2} / \mathrm{L}\right)$ & & $0,48^{(7)}$ & & & $<1$ \\
Cloro residual total $(\mathrm{mgCl} / \mathrm{L})$ & & $3,96^{(8)}$ & & & $6 \times 10^{0}$ \\
E. coli $(\mathrm{UFC} / 100 \mathrm{~mL})$ & $6 \times 10^{6}$ & $<1$ & $<1$ & & \\
Coliformes totais $(\mathrm{UFC} / 100 \mathrm{~mL})$ & $3,1 \times 10^{7}$ & $7 \times 10^{1}$ & $5 \times 10^{0}$ & $6 \times 10^{0}$ & $8 \times 10^{1}$ \\
C. perfringens $(\mathrm{NMP} / 100 \mathrm{~mL})$ & $2,4 \times 10^{5}$ & $2,7 \times 10^{3}$ & $3 \times 10^{2}$ & $1,1 \times 10^{2}$ & \\
\hline
\end{tabular}

Notas: (1) concentração de cloro aplicada $\left(\mathrm{mgCl}_{2} / \mathrm{L}\right)$, tempo de contato (min); (2) efluente bruto; (3) efluente clorado; (4) efluente clorado submetido à primeira dose de UV; (5) efluente clorado submetido à segunda dose de UV; (6) efluente clorado submetido à terceira dose de UV; concentração residual de cloro livre (7) e total (8) após ensaio com cloro; concentração residual de cloro livre (9) e total (10) após ensaio com UV. 
Tabela 5.7: Características físico-químicas e microbiológicas do esgoto no experimento VI.

$$
\text { Experimento VI }(21,74 ; 30)^{(1)}
$$

\begin{tabular}{|c|c|c|c|c|c|}
\hline Variáveis & $\mathrm{EB}^{(2)}$ & $\mathrm{EC}^{(3)}$ & $\begin{array}{c}\mathrm{EUV}_{1}{ }^{(4)} \\
\left(1 \mathrm{Wh} / \mathrm{m}^{3}\right)\end{array}$ & $\begin{array}{c}\mathrm{EUV}_{2}^{(5)} \\
\left(5 \mathrm{Wh} / \mathrm{m}^{3}\right)\end{array}$ & $\begin{array}{c}\mathrm{EUV}_{3}{ }^{(6)} \\
\left(10 \mathrm{Wh} / \mathrm{m}^{3}\right)\end{array}$ \\
\hline
\end{tabular}

\begin{tabular}{lccccc}
\hline $\mathrm{T}\left({ }^{\circ} \mathrm{C}\right)$ & 25,5 & 25 & & & \\
$\mathrm{pH}$ & 6,71 & 6,86 & 6,21 & 6,3 & 6,49 \\
Alcalinidade Total $\left(\mathrm{mgCaCO}_{3} / \mathrm{L}\right)$ & 154 & 142 & & & \\
$\mathrm{ST}(\mathrm{mg} / \mathrm{L})$ & 268 & 386 & & & \\
$\mathrm{SST}(\mathrm{mg} / \mathrm{L})$ & 58 & 101 & & & \\
$\mathrm{DQO}(\mathrm{mg} / \mathrm{L})$ & 274 & 408 & & & \\
$\mathrm{~N}-\mathrm{NH}_{3}(\mathrm{mg} / \mathrm{L})$ & 20 & 19 & & & \\
Cloro residual livre $\left(\mathrm{mgCl}_{2} / \mathrm{L}\right)$ & & $1,12^{(7)}$ & & & \\
Cloro residual total $\left(\mathrm{mgCl}_{2} / \mathrm{L}\right)$ & & $9,76^{(8)}$ & & & $5,76^{(10)}$ \\
E. coli $(\mathrm{UFC} / 100 \mathrm{~mL})$ & $3,5 \times 10^{6}$ & $<1$ & $<1$ & $<1$ & $<1$ \\
Coliformes totais $(\mathrm{UFC} / 100 \mathrm{~mL})$ & $3,3 \times 10^{7}$ & $3,8 \times 10^{2}$ & $8 \times 10^{1}$ & $1 \times 10^{2}$ & $5 \times 10^{0}$ \\
C. perfringens $(\mathrm{NMP} / 100 \mathrm{~mL})$ & $2,1 \times 10^{4}$ & $1,3 \times 10^{3}$ & $8 \times 10^{2}$ & $4 \times 10^{1}$ & $8 \times 10^{1}$ \\
\hline
\end{tabular}

Notas: (1) concentração de cloro aplicada $\left(\mathrm{mgCl}_{2} / \mathrm{L}\right)$, tempo de contato $(\mathrm{min})$; (2) efluente bruto; (3) efluente clorado; (4) efluente clorado submetido à primeira dose de UV; (5) efluente clorado submetido à segunda dose de UV; (6) efluente clorado submetido à terceira dose de UV; concentração residual de cloro livre (7) e total (8) após ensaio com cloro; concentração residual de cloro livre (9) e total (10) após ensaio com UV.

Tabela 5.8: Características físico-químicas e microbiológicas do esgoto no experimento VII. Experimento VII $(30,34 ; 10)^{(1)}$

Variáveis

\begin{tabular}{|c|c|c|c|c|}
\hline $\mathrm{EB}^{(2)}$ & $\mathrm{EC}^{(3)}$ & $\begin{array}{c}\mathrm{EUV}_{1}^{(4)} \\
\left(1 \mathrm{Wh} / \mathrm{m}^{3}\right)\end{array}$ & $\begin{array}{c}\mathrm{EUV}_{2}^{(5)} \\
\left(5 \mathrm{Wh} / \mathrm{m}^{3}\right)\end{array}$ & $\begin{array}{c}\mathrm{EUV}_{3}{ }^{(6)} \\
\left(10 \mathrm{Wh} / \mathrm{m}^{3}\right.\end{array}$ \\
\hline
\end{tabular}

\begin{tabular}{|c|c|c|c|c|c|}
\hline $\mathrm{T}\left({ }^{\circ} \mathrm{C}\right)$ & 26 & 26 & & & \\
\hline $\mathrm{pH}$ & 6,63 & 6,83 & 6,11 & 6,12 & 6,22 \\
\hline Alcalinidade Total $\left(\mathrm{mgCaCO}_{3} / \mathrm{L}\right)$ & 136 & 136 & & & \\
\hline $\mathrm{ST}(\mathrm{mg} / \mathrm{L})$ & 199 & 382 & & & \\
\hline SST (mg/L) & 22 & 30 & & & \\
\hline DQO $(\mathrm{mg} / \mathrm{L})$ & 101 & 88 & & & \\
\hline $\mathrm{N}-\mathrm{NH}_{3}(\mathrm{mg} / \mathrm{L})$ & 18 & 17 & & & \\
\hline Cloro residual livre $\left(\mathrm{mgCl}_{2} / \mathrm{L}\right)$ & & $2,92^{(7)}$ & & & $3,2^{(9)}$ \\
\hline Cloro residual total $\left(\mathrm{mgCl}_{2} / \mathrm{L}\right)$ & & $20,88^{(8)}$ & & & $13,88^{(10)}$ \\
\hline E. coli $(\mathrm{UFC} / 100 \mathrm{~mL})$ & $5,9 \times 10^{5}$ & $1,0 \times 10^{0}$ & $<1$ & $<1$ & $<1$ \\
\hline Coliformes totais (UFC/100mL) & $2 \times 10^{6}$ & $2,7 \times 10^{2}$ & $2,8 \times 10^{1}$ & $1,1 \times 10^{1}$ & $6 \times 10^{0}$ \\
\hline C. perfringens (NMP/100mL) & $5 \times 10^{3}$ & $<1$ & $7 \times 10^{1}$ & $2 \times 10^{1}$ & $2 \times 10^{1}$ \\
\hline
\end{tabular}

Notas: (1) concentração de cloro aplicada $\left(\mathrm{mgCl}_{2} / \mathrm{L}\right)$, tempo de contato (min); (2) efluente bruto; (3) efluente clorado; (4) efluente clorado submetido à primeira dose de UV; (5) efluente clorado submetido à segunda dose de UV; (6) efluente clorado submetido à terceira dose de UV; concentração residual de cloro livre (7) e total (8) após ensaio com cloro; concentração residual de cloro livre (9) e total (10) após ensaio com UV. 
Tabela 5.9: Características físico-químicas e microbiológicas do esgoto no experimento VIII.

$$
\text { Experimento VIII }(31,78 ; 20)^{(1)}
$$

\begin{tabular}{|c|c|c|c|c|}
\hline Variáveis & $\mathrm{EB}^{(2)}$ & $\mathrm{EC}^{(3)}$ & $\begin{array}{c}\mathrm{EUV}_{1}^{(4)} \\
\left(1 \mathrm{Wh} / \mathrm{m}^{3}\right)\end{array}$ & $\begin{array}{c}\mathrm{EUV}_{2}{ }^{(5)} \\
\left(5 \mathrm{Wh} / \mathrm{m}^{3}\right)\end{array}$ \\
\hline
\end{tabular}

\begin{tabular}{lccccc}
\hline $\mathrm{T}\left({ }^{\circ} \mathrm{C}\right)$ & 25 & 25 & & & \\
$\mathrm{pH}$ & 6,36 & 6,65 & 6,55 & 6,48 & 6,75 \\
Alcalinidade Total $\left(\mathrm{mgCaCO}_{3} / \mathrm{L}\right)$ & 257 & 218 & & & \\
$\mathrm{ST}(\mathrm{mg} / \mathrm{L})$ & 290 & 389 & & & \\
$\mathrm{SST}(\mathrm{mg} / \mathrm{L})$ & 42 & 53 & & & \\
$\mathrm{DQO}(\mathrm{mg} / \mathrm{L})$ & 176 & 237 & & & \\
$\mathrm{~N}^{\mathrm{NH}}{ }_{3}(\mathrm{mg} / \mathrm{L})$ & 53 & 42 & & & $1,22^{(9)}$ \\
Cloro residual livre $\left(\mathrm{mgCl}_{2} / \mathrm{L}\right)$ & & $1,28^{(7)}$ & & & $10,56^{(10)}$ \\
Cloro residual total $\left(\mathrm{mgCl}_{2} / \mathrm{L}\right)$ & & $17,12^{(8)}$ & & $<1$ & $<1$ \\
E. coli $(\mathrm{UFC} / 100 \mathrm{~mL})$ & $1,8 \times 10^{5}$ & $<1$ & $<1$ & $<1$ \\
Coliformes totais $(\mathrm{UFC} / 100 \mathrm{~mL})$ & $6,6 \times 10^{6}$ & $1,1 \times 10^{2}$ & $1 \times 10^{2}$ & $8 \times 10^{0}$ & $<1$ \\
C. perfringens $(\mathrm{NMP} / 100 \mathrm{~mL})$ & $9 \times 10^{3}$ & $5 \times 10^{2}$ & $2,3 \times 10^{2}$ & $2 \times 10^{1}$ & $<1$ \\
\hline
\end{tabular}

Notas: (1) concentração de cloro aplicada $\left(\mathrm{mgCl}_{2} / \mathrm{L}\right)$, tempo de contato (min); (2) efluente bruto; (3) efluente clorado; (4) efluente clorado submetido à primeira dose de UV; (5) efluente clorado submetido à segunda dose de UV; (6) efluente clorado submetido à terceira dose de UV; concentração residual de cloro livre (7) e total (8) após ensaio com cloro; concentração residual de cloro livre (9) e total (10) após ensaio com UV.

Tabela 5.10: Características físico-químicas e microbiológicas do esgoto no experimento IX.

$$
\text { Experimento IX }(30,4 ; 30)^{(1)}
$$

\begin{tabular}{lccccc}
\multicolumn{1}{c}{ Variáveis } & $\mathrm{EB}^{(2)}$ & $\mathrm{EC}^{(3)}$ & $\begin{array}{c}\mathrm{EUV}_{1}^{(4)} \\
\left(1 \mathrm{Wh} / \mathrm{m}^{3}\right)\end{array}$ & $\begin{array}{c}\mathrm{EUV}_{2}^{(5)} \\
\left(5 \mathrm{Wh} / \mathrm{m}^{3}\right)\end{array}$ & $\begin{array}{c}\mathrm{EUV}_{3}^{(6)} \\
\left(10 \mathrm{Wh} / \mathrm{m}^{3}\right)\end{array}$ \\
\hline $\mathrm{T}\left({ }^{\circ} \mathrm{C}\right)$ & 26 & 26 & & & \\
$\mathrm{pH}$ & 6,64 & 6,83 & 7,08 & 7,1 & 6,82 \\
Alcalinidade Total $\left(\mathrm{mgCaCO}_{3} / \mathrm{L}\right)$ & 202 & 181 & & & \\
$\mathrm{ST}(\mathrm{mg} / \mathrm{L})$ & 263 & 455 & & & \\
$\mathrm{SST}(\mathrm{mg} / \mathrm{L})$ & 59 & 20 & & & \\
$\mathrm{DQO}(\mathrm{mg} / \mathrm{L})$ & 176 & 134 & & & \\
$\mathrm{~N}-\mathrm{NH}{ }_{3}(\mathrm{mg} / \mathrm{L})$ & 24 & 23 & & & \\
Cloro residual livre $\left(\mathrm{mgCl}_{2} / \mathrm{L}\right)$ & & $9,35^{(7)}$ & & & \\
Cloro residual total $(\mathrm{mgCl} / \mathrm{L})$ & & $30^{(8)}$ & & $<, 88^{(10)}$ \\
E. coli $(\mathrm{UFC} / 100 \mathrm{~mL})$ & $6,9 \times 10^{5}$ & $<1$ & $<1$ & $<1$ & $<1$ \\
Coliformes totais $(\mathrm{UFC} / 100 \mathrm{~mL})$ & $2,3 \times 10^{6}$ & $<1$ & $<1$ & $<1$ & $<1$ \\
C. perfringens $(\mathrm{NMP} / 100 \mathrm{~mL})$ & $3,3 \times 10^{3}$ & $<1$ & $<1$ & $<1$ & $<1$ \\
\hline
\end{tabular}

Notas: (1) concentração de cloro aplicada $\left(\mathrm{mgCl}_{2} / \mathrm{L}\right)$, tempo de contato (min); (2) efluente bruto; (3) efluente clorado; (4) efluente clorado submetido à primeira dose de UV; (5) efluente clorado submetido à segunda dose de UV; (6) efluente clorado submetido à terceira dose de UV; concentração residual de cloro livre (7) e total (8) após ensaio com cloro; concentração residual de cloro livre (9) e total (10) após ensaio com UV. 


\subsection{1 pH}

Quando o hipoclorito de sódio é adicionado á água, este produz ácido hipocloroso assim como quando o cloro é hidrolisado.

Nos experimentos I, II e III, nos quais foram adicionados $10 \mathrm{mgCl}_{2} / \mathrm{L}$ e foram submetidos aos tempos de contato de 10, 20 e 30 minutos, respectivamente, observa-se diminuição no $\mathrm{pH}$ após a adição de hipoclorito de sódio. Ao aumentar a dose de cloro aplicada para 20 e $30 \mathrm{mgCl}_{2} / \mathrm{L}$ observa-se a tendência em aumento no $\mathrm{pH}$ (Figura 5.1).

Ao aumentar a quantidade de hipoclorito de sódio adicionado às amostras de efluente secundário ocorre a tendência de aumento nos valores de $\mathrm{pH}$, como mostra a equação (5.1):

$\mathrm{NaOCl}+\mathrm{H}_{2} \mathrm{O} \rightleftharpoons \mathrm{HOCl}+\mathrm{Na}^{+}+\mathrm{OH}^{-}$

Ademais, a adição de cloreto, inerente à composição da solução de cloro utilizada nos ensaios de desinfecção, pode alterar a força iônica da amostra desinfetada, podendo assim interferir no $\mathrm{pH}$.

O pH médio da amostra do reator UASB não desinfetado (EB) é 6,53 (Tabela 5.11). O $\mathrm{pH}$ das amostras desinfetadas encontra-se no intervalo de 5,57 a 7,10, situando-se na faixa de $\mathrm{pH}$ onde 80 a $100 \%$ do cloro está presente na forma de ácido hipocloroso, espécie química de forte poder desinfetante (Figura 5.1 e Tabelas 5.2 a 5.10).

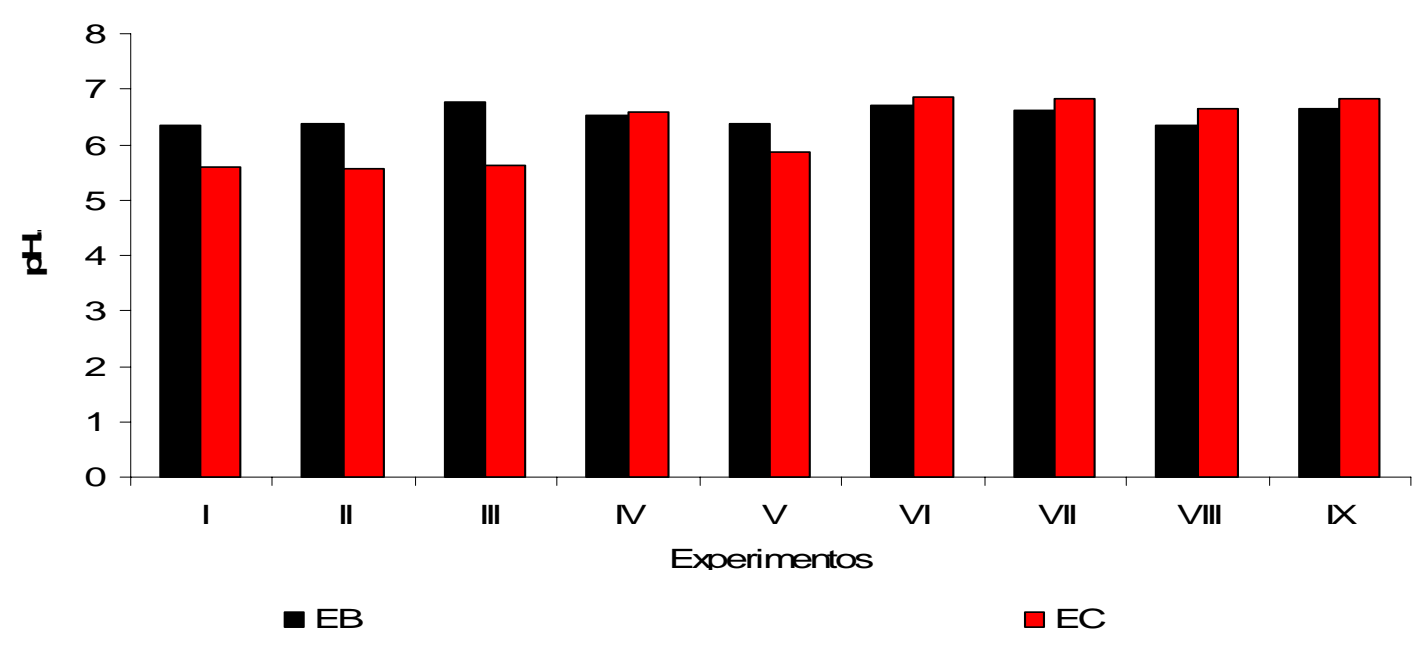

Figura 5.1- Variação do pH com a aplicação de cloro.

Na Figura 5.2 pode-se observar que há correlação linear em relação às dosagens aplicadas e tempo de contato. A Figura "A" apresenta para o tempo de contato de 10 minutos as diferentes doses de cloro aplicada 10, 20 e $30 \mathrm{mgCl}_{2} / \mathrm{L}$, experimentos I, IV e VII 
respectivamente. A Figura "B" representa o tempo de contato de 20 minutos e mesma dosagens de cloro aplicada que em "A" e a Figura"C" é referente ao tempo de contato de 30 minutos.
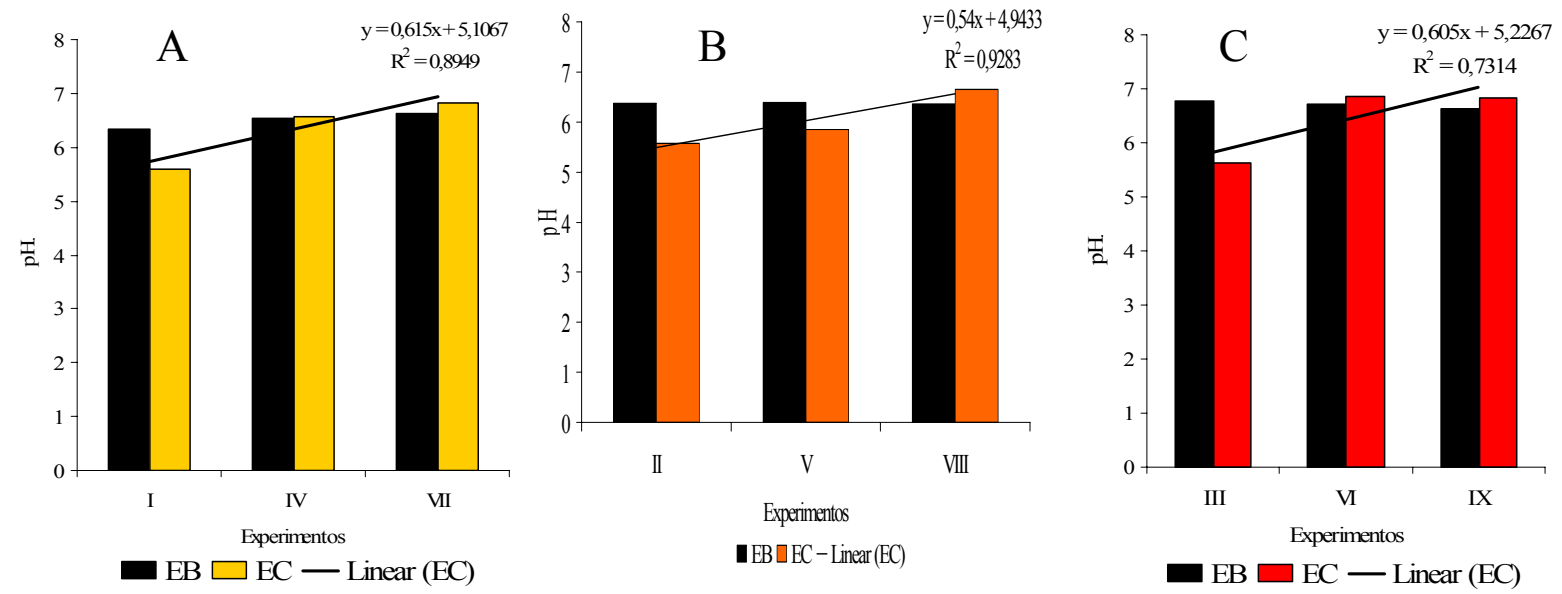

Figura 5.2- Variação do pH com a aplicação de cloro

Ao aumentar a dose de cloro aplicada de 10 para $30 \mathrm{mgCl}_{2} / \mathrm{L}$ parece alterar o equilíbrio químico da matriz do efluente. Assim, a dosagem de $10 \mathrm{mgCl}_{2} / \mathrm{L}$ parece promover uma tendência em acidificar o efluente do reator UASB, e a dosagem de $30 \mathrm{mgCl} / 2$ provoca uma neutralização do pH do meio onde o cloro foi aplicado.

A média do $\mathrm{pH}$ foi de 6,53 no efluente bruto, 6,26 no efluente clorado e de 6,26 no efluente sujeito à radiação UV, como pode ser visto na Tabela 5.11 .

Tabela 5.11: Análise estatística dos valores de pH do ensaio de cloração

\begin{tabular}{lccccc}
\hline & $\mathrm{EB}$ & $\mathrm{EC}$ & $\mathrm{EUV}_{1}$ & $\mathrm{EUV}_{2}$ & $\mathrm{EUV}_{3}$ \\
\hline Média & 6,53 & 6,26 & 6,18 & 6,23 & 6,24 \\
Erro padrão & 0,05533 & 0,19556 & 0,14113 & 0,1382 & 0,13184 \\
Mediana & 6,53 & 6,58 & 6,12 & 6,13 & 6,22 \\
Desvio padrão & 0,16598 & 0,58667 & 0,42338 & 0,41461 & 0,39551 \\
Variância da amostra & 0,02755 & 0,34418 & 0,17925 & 0,1719 & 0,15643 \\
Curtose & $-1,756$ & $-2,3255$ & 1,65661 & 1,55171 & $-1,0498$ \\
Assimetria & 0,24335 & $-0,2503$ & 1,19481 & 0,98391 & 0,19324 \\
Intervalo & 0,43 & 1,29 & 1,37 & 1,4 & 1,16 \\
Mínimo & 6,35 & 5,57 & 5,71 & 5,7 & 5,66 \\
Máximo & 6,78 & 6,86 & 7,08 & 7,1 & 6,82 \\
Soma & 58,77 & 56,39 & 55,66 & 56,12 & 56,16 \\
Contagem & 9 & 9 & 9 & 9 & 9 \\
\hline
\end{tabular}

Nota: $\mathrm{EB}=$ efluente bruto, aqueles não desinfetados; $\mathrm{EC}=$ efluente do reator UASB após a cloração; $\mathrm{EUV}_{1}=$ efluente clorado após desinfecção com a primeira dose de UV; $\mathrm{EUV}_{2}=$ efluente clorado após a segunda dose de UV e EUV $E_{3}=$ efluente clorado após a terceira dose de UV. 


\subsubsection{DQO}

A Figura 5.3 representa a variação da DQO do efluente bruto (EB) e do clorado (EC) para todos os experimentos realizados.

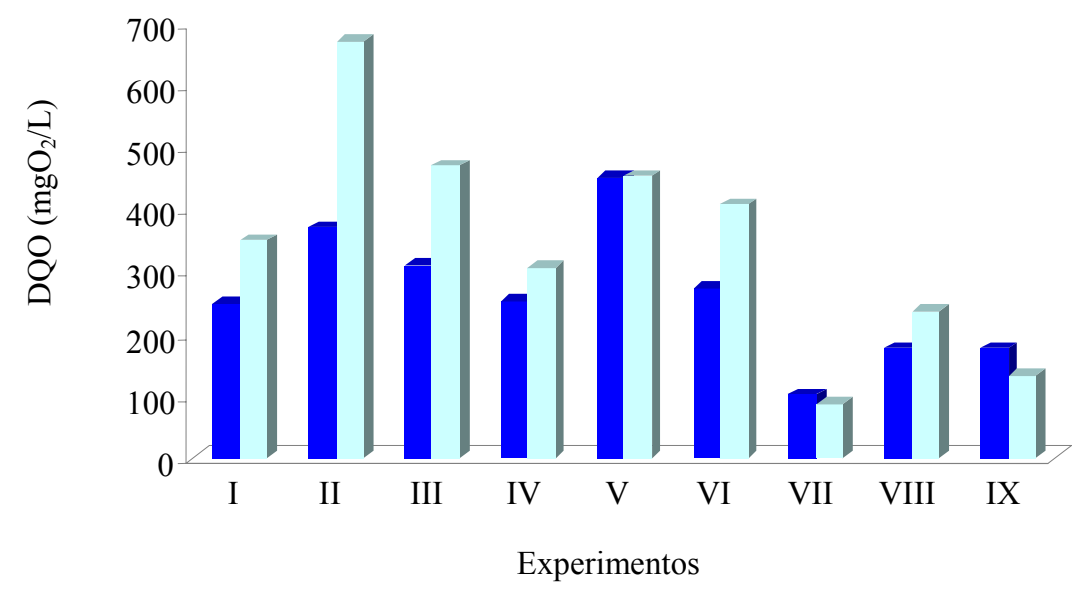

$\square \quad \mathrm{EB} \quad \square \quad \mathrm{EC}$

Figura 5.3: Variação da DQO no efluente bruto e no efluente clorado nos ensaios de desinfecção com cloro.

A DQO média no efluente bruto foi de $263 \mathrm{mg} / \mathrm{L}$ e no efluente clorado foi de 346 $\mathrm{mg} / \mathrm{L}$ (Tabela 5.12).

Tabela 5.12: Análise estatística do Efluente Bruto e do clorado para a DQO.

\begin{tabular}{lcc}
\hline & EB & EC \\
\hline \hline Média & 263 & 346 \\
Erro padrão & 35,6657 & 60,2171 \\
Mediana & 252,5 & 349,8 \\
Desvio padrão & 106,9973 & 180,6515 \\
Variância da & & \\
amostra & 11448,42 & 32634,98 \\
Assimetria & 0,3645 & 0,2544 \\
Intervalo & 351,2 & 582,7 \\
Mínimo & 101,3 & 88,1 \\
Máximo & 452,5 & 670,8 \\
\hline
\end{tabular}

Considerando a cinética de reação do cloro com a matéria orgânica, geralmente de primeira ordem, não era esperado o comportamento observado nos ensaios, ou seja, a remoção de DQO por oxidação com cloro não foi proporcional à dosagem de cloro aplicada ou à demanda de cloro. Na maioria dos ensaios, houve aumento de DQO, exceto nos ensaios VII e IX. 
A DQO é obtida indiretamente pela quantidade equivalente de um oxidante, normalmente permanganato ou dicromato em solução ácida, necessária para oxidação dos constituintes orgânicos de uma amostra sob condições controladas. A quantidade consumida de oxidante é expressa em termos de sua equivalência com oxigênio.

$\mathrm{Na}$ tentativa de determinar a existência de uma tendência de aumento nos valores de DQO com a adição do desinfetante, foram realizados os experimentos:

(A) para uma amostra de efluente do reator UASB, na qual foi adicionado $5 \mathrm{mgCl}_{2} / \mathrm{L}$ em 10 minutos de tempo de contato, foi adicionado sulfato de mercúrio (somente para a amostra clorada) (Figura 5.4);

(B) em outra amostra do efluente do reator UASB, foi avaliada a adição do sulfato de mercúrio em diferentes quantidades, tanto no efluente do reator UASB (Figura 5.5) quanto neste efluente, após a aplicação de $30 \mathrm{mgCl}_{2} / \mathrm{L}$ em 30 minutos de tempo de contato (Figura $5.6)$.

O sal sulfato de mercúrio é recomendado pelo Standard Methods for Examination of Water and Wastewater (APHA, 1998) para remover a interferência de íons cloreto e brometo, interferentes na DQO.

O sulfato de mercúrio tem a propriedade de precipitar o cloreto presente nas amostras. O íon cloreto pode estar presente no esgoto tratado e nas soluções de hipoclorito de sódio comerciais (solução usada no ensaio de desinfecção com cloro).

Sabe-se que a presença de cloreto nos esgotos é comum e de difícil remoção (PIVELI \& KATO, 2006).

Seguiu-se a proporção sugerida no APHA (1998) de $50 \mathrm{~mL}$ de amostra para cada $1 \mathrm{~g}$ de $\mathrm{HgSO}_{4}$, Para otimização do uso de reagente foi utilizado a proporção de $25 \mathrm{~mL}$ de amostra para $0,5 \mathrm{~g}$ de $\mathrm{HgSO}_{4}$. 


$$
\mathrm{DQO}+\mathrm{HgSO} 4
$$

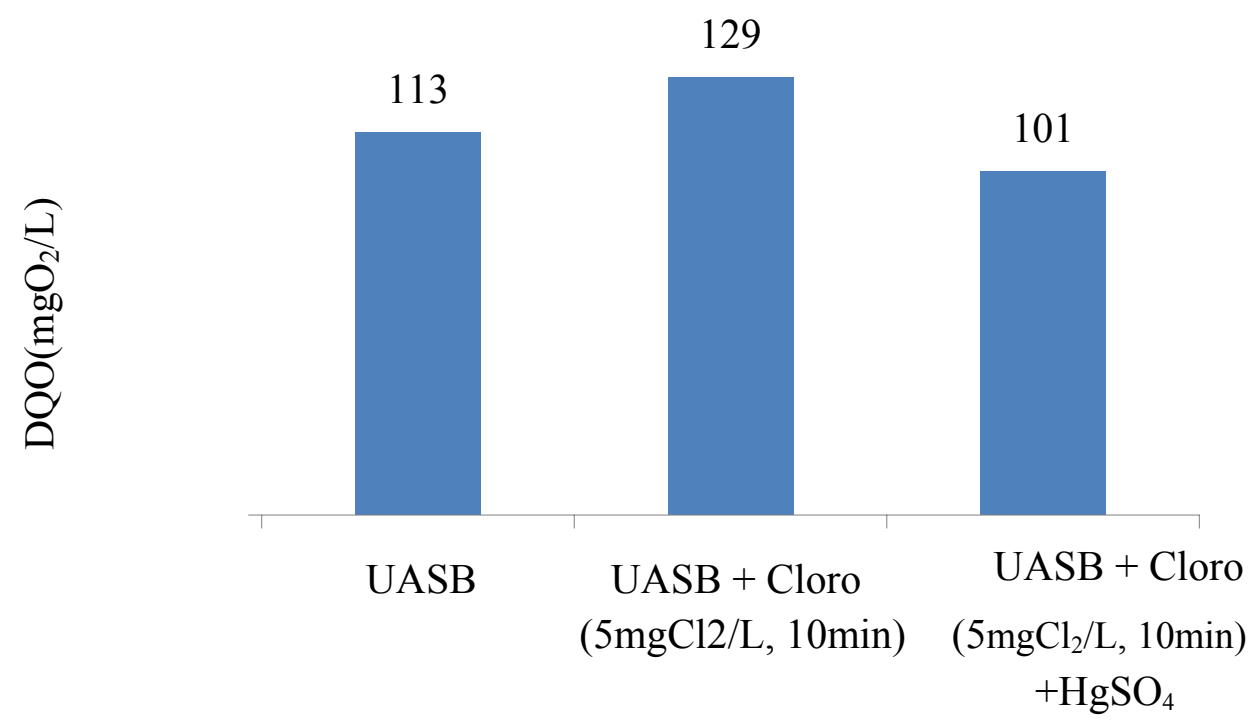

Figura 5.4: Interferência do cloreto na determinação da DQO da amostra clorada. O resultado mostra que a DQO na amostra do reator UASB aumenta de 113 para 129 quando é adicionado cloro, e diminui de 129 para 101 quando é adicionado o sulfato de mercúrio somente na amostra clorada.

No experimento $\mathrm{B}$, foi feito o teste para avaliar a alteração dos valores de DQO variando a quantidade de sulfato de mercúrio, tanto para a amostra do efluente bruto (Figura 5.5) quanto para esta amostra após a cloração (Figura 5.6).

$$
\text { DQO efluente UASB }+\mathrm{HgSO} 4
$$

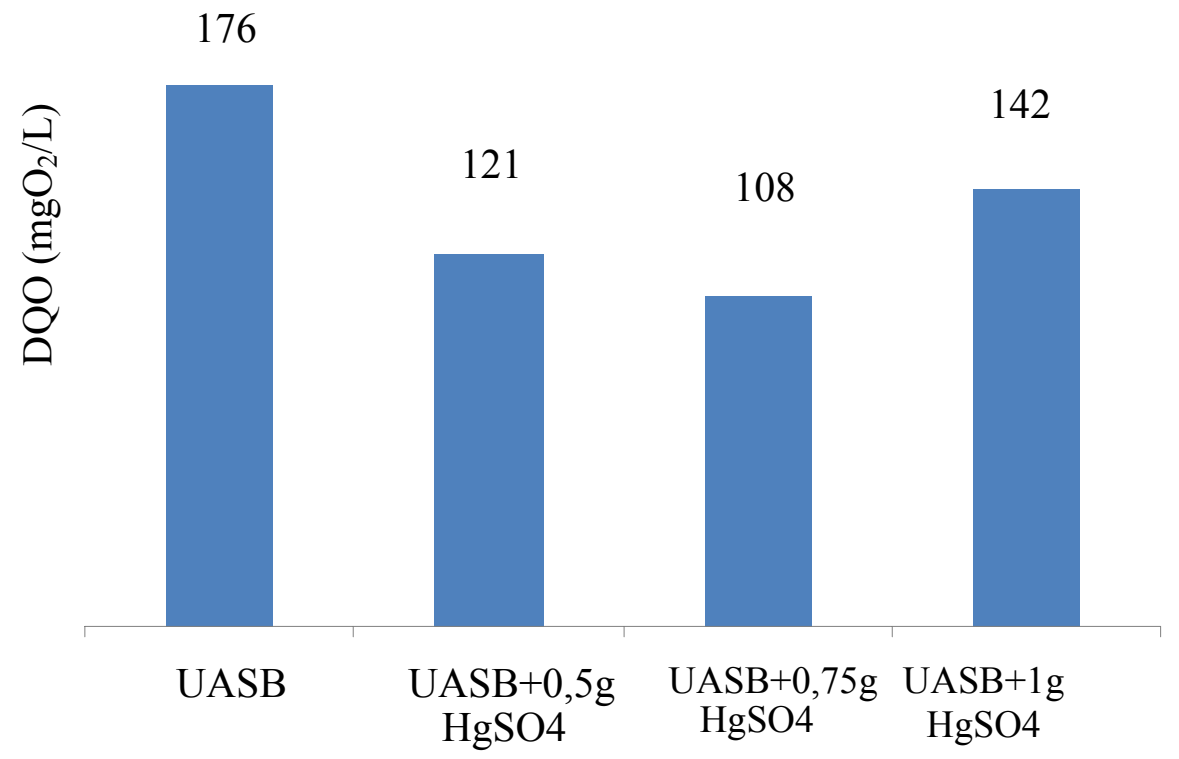

Figura 5.5: Valores de DQO do efluente do reator UASB para diferentes concentrações de Sulfato de mercúrio. 
Observou-se que, na amostra do efluente do reator UASB, a DQO diminuiu quando foi adicionado até $0,75 \mathrm{~g}$ de $\mathrm{HgSO}_{4}$ em $25 \mathrm{~mL}$ de amostra de água residuária e aumentou quando foi adicionado $1 \mathrm{~g}$ de $\mathrm{HgSO}_{4}$ (Figura 5.5). Por outro lado notou-se uma diminuição de 176 para $134 \mathrm{mgO}_{2} / \mathrm{L}$ quando comparada com a amostra de UASB (Figuras Figura 5.5 e 5.6). Além disso, quando foi adicionado $\mathrm{HgSO}_{4}$ nessa mesma amostra, seus valores aumentaram de 134 para 155 com $0,75 \mathrm{~g}$ deste sal e diminuíram para 116 com $1 \mathrm{~g}$ de $\mathrm{HgSO}_{4}$.

Nota-se que nas Figuras Figura 5.5 e 5.6 a alteração nos valores de DQO quando quantidades variáveis de sulfato de mercúrio foram adicionadas. Observa-se que o aumento nas quantidades do sal de mercúrio pode não gerar resultados lineares decrescentes na DQO.

A Figura 5.6 representa o que ocorreu quando foram adicionadas diferentes quantidades de sulfato de mercúrio à amostra clorada. Observa-se também que não foi registrado um padrão de resultado com a crescente adição do sulfato de mercúrio.

DQO da amostra clorada $+\mathrm{HgSO}_{4}$

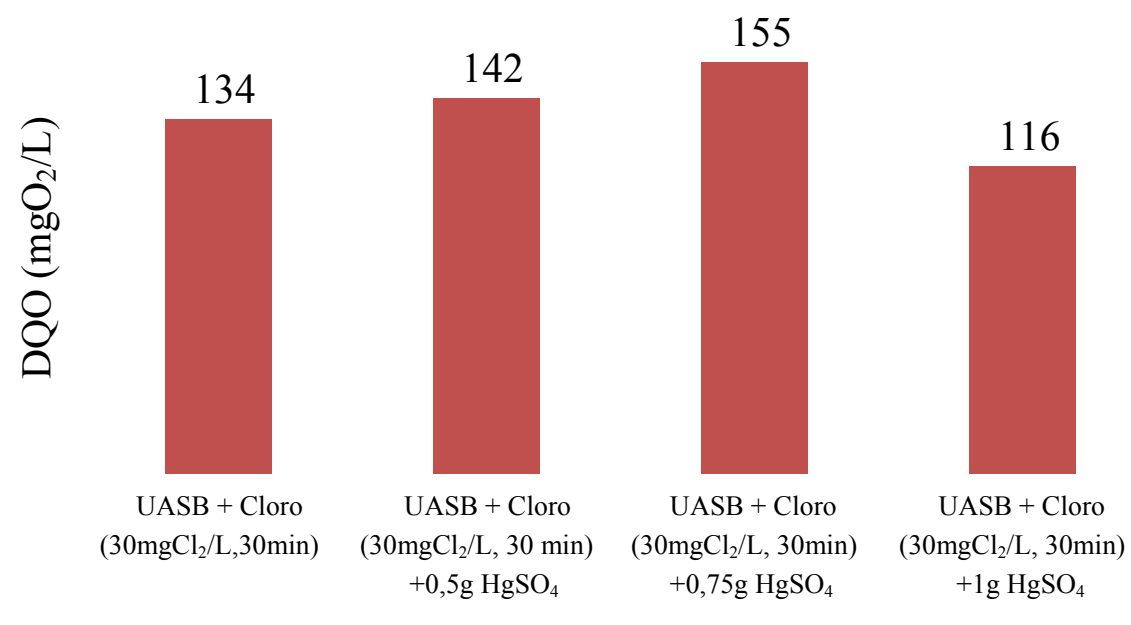

Figura 5.6: Valores de DQO para a amostra desinfetada com cloro em diferentes concentrações de sulfato de mercúrio.

O APHA (1998) explica que o íon cloreto é o interferente mais comum na determinação de DQO. O cloreto pode alterar o valor da DQO podendo causar tanto aumento, ao ser oxidado pelo dicromato, quanto diminuição, ao reagir com a prata do catalisador e precipitar cloreto de prata, diminuindo a capacidade oxidativa do reagente (SOUTO, 2009). O mesmo autor acentua que as dificuldades na determinação da DQO causadas pelo cloreto podem ser minimizadas, mas não eliminadas, pela complexação com sulfato de mercúrio.

Como foram usadas concentrações variadas de cloro, e não foram feitas análises para 
quantificar os cloretos no efluente bruto, no clorado e na solução de cloro usada na desinfecção, a determinação do valor de sulfato de mercúrio necessária para remover a interferência do íon cloreto seria dificultosa, portanto decidiu-se fazer as análises de DQO sem a adição de $\mathrm{HgSO}_{4}$.

\subsubsection{Sólidos Totais}

A Figura 5.7 representa a variação dos sólidos totais antes e após a cloração. Nota-se aumento nos valores deste parâmetro com a adição do cloro em todos os experimentos. $\mathrm{O}$ aumento pode ser advindo da adição de solutos, que possam estar presentes na composição da solução de hipoclorito de sódio.

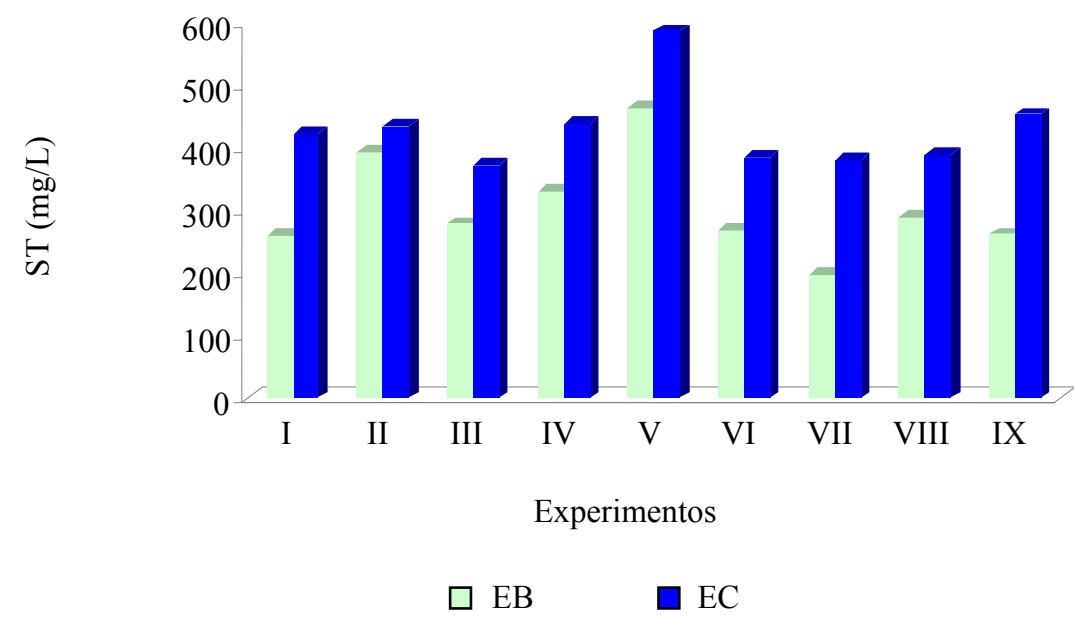

Figura 5.7: Variação dos Sólidos Totais nos ensaios de cloro/UV

Nota-se na Tabela 5.13 que houve um aumento médio de 1,4 vezes no valor de ST quando se aplicou cloro.

Tabela 5.13: Análise estatística do efluente bruto e do efluente clorado para ST.

\begin{tabular}{lll}
\hline & EB & EC \\
\hline Média & 305 & 430 \\
Erro padrão & 26,8068 & 22,0011 \\
Mediana & 278,5 & 422,5 \\
Desvio padrão & 80,4204 & 66,0032 \\
Variância da & & \\
amostra & 6467,444 & 4356,424 \\
Assimetria & 1,0327 & 1,9438 \\
Intervalo & 267 & 214,5 \\
Mínimo & 198,5 & 373 \\
Máximo & 465,5 & 587,5 \\
\hline
\end{tabular}




\subsubsection{Sólidos Suspensos Totais}

Em se tratando dos sólidos suspensos totais, a Figura 5.8 representa a variação deste parâmetro no efluente bruto e no efluente clorado. Diferentemente dos ST, não ocorreu um padrão de aumento ou diminuição deste parâmetro após a cloração. Pode-se inferir que o material existente, tanto dissolvido quanto particulado nas amostras tinha qualidades únicas, visto que cada experimento utilizava amostra de esgoto com particular qualidade.

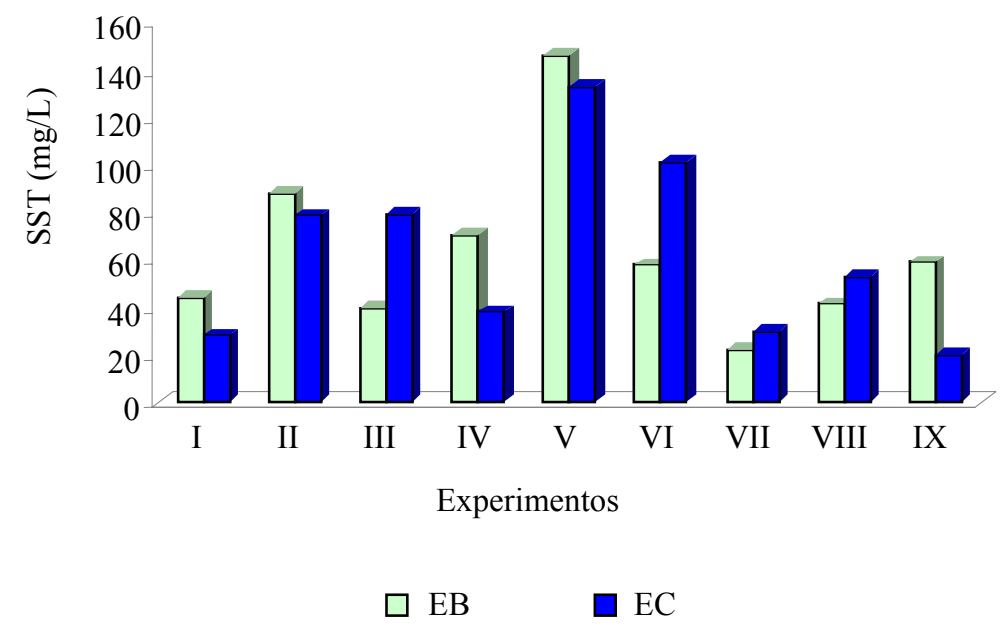

Figura 5.8: Variação dos Sólidos Suspensos Totais nos ensaios de cloro/UV

Para melhorar o efeito de desinfecção WANG et al., (2006) combinaram processos de desinfecção (cloração seguido de radiação UV). Os seus resultados mostraram que a presença de sólidos suspensos, especialmente de partículas maiores, teve grande impacto na eficiência de desinfecção com UV, principalmente para este desinfetante quando aplicado sozinho. Coliformes associados a partículas com diâmetro maior que $10 \mu \mathrm{m}$ são difíceis de serem inativados, e são os responsáveis pela cauda (tailing) em curvas de inativação. Pré-cloração pode diminuir o número de partículas em efluentes secundários e transformar partículas maiores em menores, transformado-as em parcela dissolvida, diminuindo assim a concentração de SST e reduzindo a influência das partículas na desinfecção com UV, realçando a habilidade dos processos combinados mesmo em efluentes contendo carga de partículas.

Na Tabela 5.14 estão apresentados os valores das variáveis estatísticas para os valores de SST no efluente bruto e no clorado nos experimentos realizados. 
Tabela 5.14: Análise estatística dos SST do efluente bruto e do efluente clorado.

\begin{tabular}{lll}
\hline & EB & EC \\
\hline \hline Média & 63,4 & 62,6 \\
Erro padrão & 12,2056 & 12,8402 \\
Mediana & 58,15 & 53,3 \\
Desvio padrão & 36,6169 & 38,5207 \\
Variância da & & \\
amostra & 1340,798 & 1483,849 \\
Assimetria & 1,6093 & 0,7235 \\
Intervalo & 124,6 & 113,7 \\
Mínimo & 22,05 & 19,85 \\
Máximo & 146,65 & 133,55 \\
\hline
\end{tabular}

\subsubsection{Nitrogênio amoniacal, pH e Temperatura}

Uma das dificuldades para tratamento de esgoto sanitário ou industrial decorre da sua composição química complexa. Muitos desses efluentes contém quantidades apreciáveis de amônia e a cloração dessas águas poluídas resulta na formação de ácido hipocloroso (HOCl), um composto clorado com alto poder desinfetante. No entanto, esse composto, na presença de amônia, pode ser convertido em monocloramina e outras cloraminas que possuem caráter desinfetante menor.

Ao se aplicar dosagens crescentes de cloro em águas contendo amônia, as cloraminas decompõem-se facilitando a formação de cloro residual livre.

$\mathrm{O}$ pH é um fator muito importante para garantir a prevalência de espécies químicas cloradas com poder desinfetante. $\mathrm{O}$ pH observado nas amostras analisadas, tanto para as amostras brutas (sem cloração) quanto para as cloradas, apresentou valores favoráveis para a ação desinfetante do cloro, ou seja, abaixo de 7 e não inferior a 5,5 como é evidenciado na Tabela 5.15. 
Tabela 5.15: Variação do $\mathrm{pH}$, temperatura, $\mathrm{N}^{-\mathrm{NH}_{3}}$ para efluente bruto (EB) e clorado (EC).

\begin{tabular}{|c|c|c|c|c|c|c|c|c|c|}
\hline \multirow[t]{2}{*}{ Experimento } & \multirow{2}{*}{$\begin{array}{l}\text { Tempo de } \\
\text { contato } \\
\text { com Cloro } \\
\text { (min) }\end{array}$} & \multirow{2}{*}{$\begin{array}{c}\text { Cloro } \\
\text { aplicado } \\
\left(\mathrm{mgCl}_{2} / \mathrm{L}\right)\end{array}$} & \multirow{2}{*}{$\begin{array}{c}\text { Cloro } \\
\text { residual } \\
\text { livre } \\
\left(\mathrm{mgCl}_{2} / \mathrm{L}\right)\end{array}$} & \multirow{2}{*}{$\begin{array}{l}\text { Cloro residual } \\
\text { combinado } \\
\left(\mathrm{mgCl}_{2} / \mathrm{L}\right)\end{array}$} & \multirow[t]{2}{*}{$\begin{array}{c}\mathrm{T} \\
\left({ }^{\circ} \mathrm{C}\right)\end{array}$} & \multicolumn{2}{|c|}{$\mathrm{pH}$} & \multicolumn{2}{|c|}{$\begin{array}{c}\mathrm{NH}_{3} \\
(\mathrm{mg} / \mathrm{L})\end{array}$} \\
\hline & & & & & & EB & $\mathrm{EC}$ & EB & $\mathrm{EC}$ \\
\hline I & 10 & 9,8 & 0,31 & 4,2 & 22,5 & 6,35 & 5,6 & 20 & 20 \\
\hline II & 20 & 9,6 & 0,14 & 1,18 & 22,0 & 6,38 & 5,57 & 23 & 19 \\
\hline III & 30 & 9,36 & 0,31 & 4,41 & 22,5 & 6,78 & 5,62 & 7 & $0 *$ \\
\hline IV & 10 & 22,5 & 0,9 & 14,86 & 26 & 6,53 & 6,58 & 22 & 18 \\
\hline $\mathrm{V}$ & 20 & 20,48 & 0,48 & 3,48 & 25,5 & 6,39 & 5,85 & 15 & 13 \\
\hline VI & 30 & 21,74 & 1,12 & 8,64 & 25,5 & 6,71 & 6,86 & 20 & 19 \\
\hline VII & 10 & 30,34 & 2,92 & 17,96 & 26 & 6,63 & 6,83 & 18 & 17 \\
\hline VIII & 20 & 31,78 & 1,28 & 15,84 & 25 & 6,36 & 6,65 & 53 & 42 \\
\hline IX & 30 & 30,4 & 9,35 & 20,65 & 26 & 6,64 & 6,83 & 24 & 23 \\
\hline
\end{tabular}

Nota: $\mathrm{EB}=$ efluente bruto; $\mathrm{EC}=$ efluente clorado;

*Valor abaixo do limite de detecção.

Na Figura 5.9 observa-se que foi detectada nas amostras cloradas uma pequena diminuição nos valores de N-amoniacal. Entretanto, em alguns ensaios a quantidade de Namoniacal manteve-se inalterada após a adição do cloro, com exceção dos ensaios II, III, IV e VIII nos quais foi visualizado consumo de amônia. Possivelmente o cloro tenha se transformado em compostos combinados como as cloraminas.

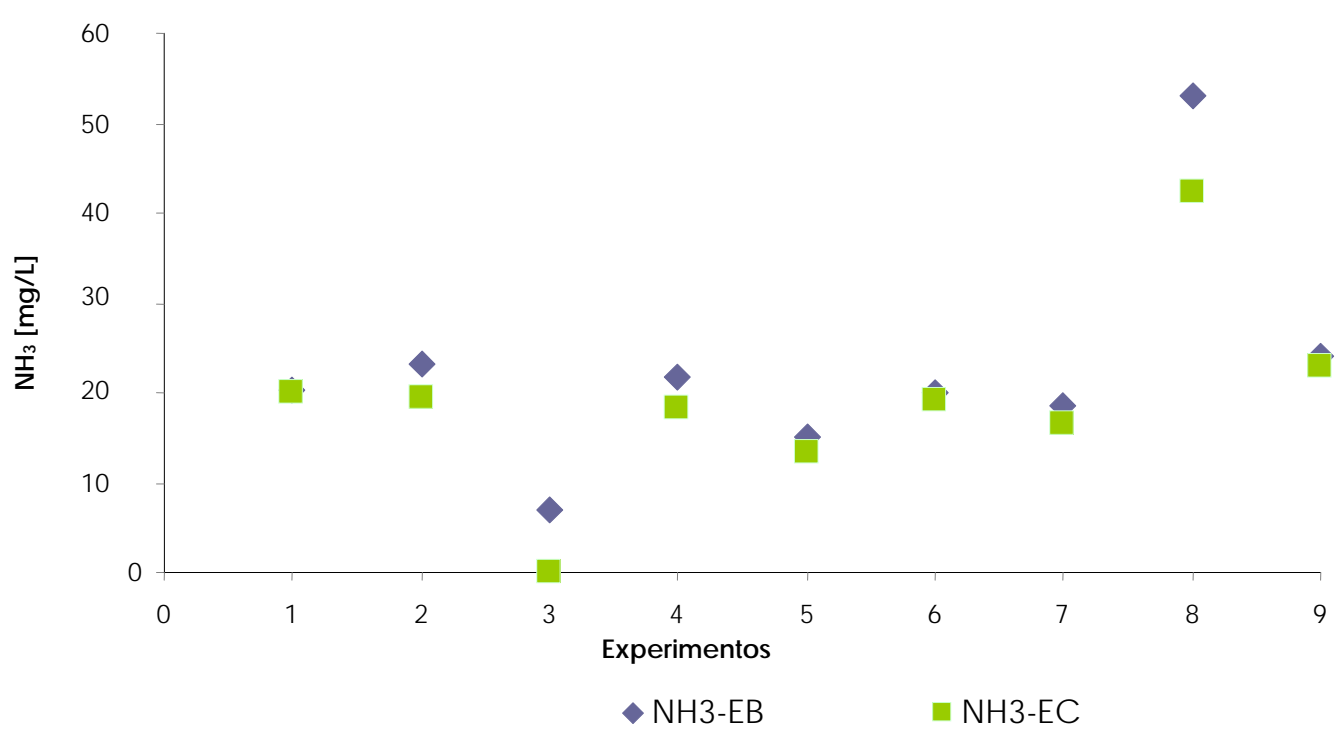

Figura 5.9: Variação do Nitrogênio amoniacal para a amostra de efluente bruto (EB) e do efluente clorado (EC). 


\subsubsection{Cinética do cloro}

\subsubsection{Inativação de $C$. perfringens e coliformes totais na desinfecção somente com cloro}

Na Figura 5.10 observa-se a inativação das bactérias $C$. perfringens e coliformes totais quando sofreram a ação do cloro em diversas combinações de concentração de desinfetante e tempo de contato (CT), ajustados pelos modelos aplicados. A ausência da bactéria E. coli está ligada ao fato de que ela não resistiu à exposição ao cloro nas dosagens estudadas.

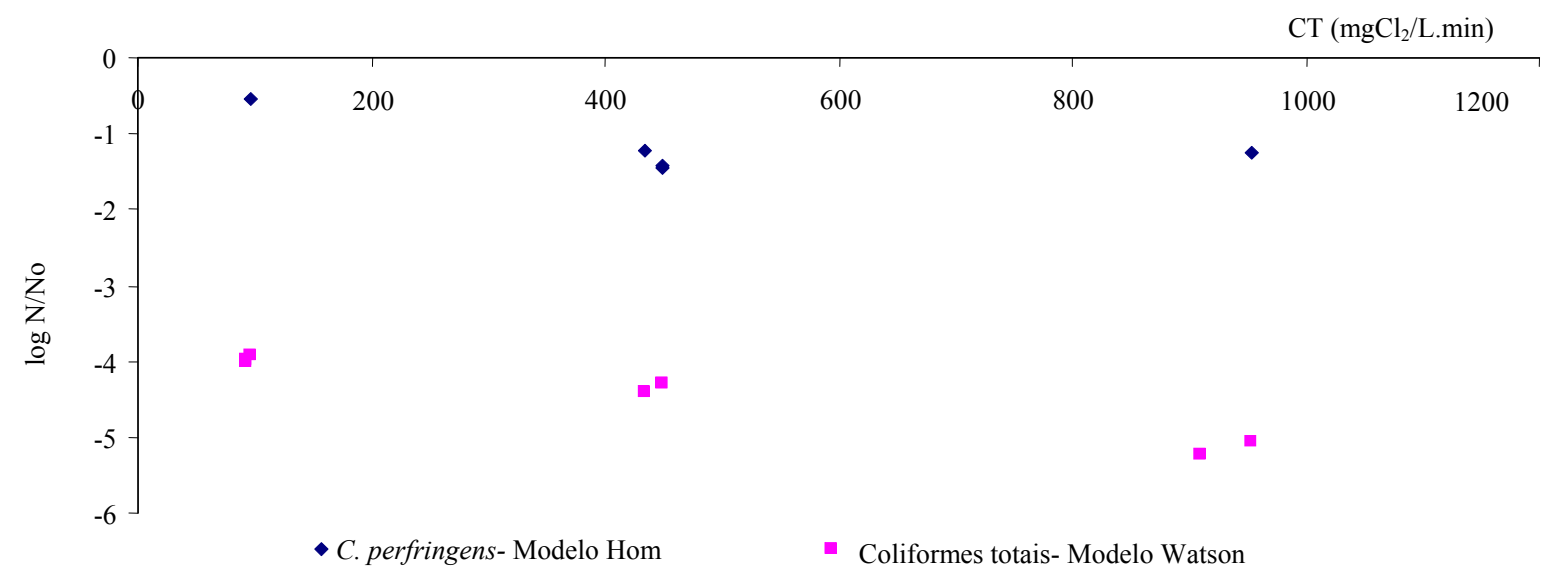

Figura 5.10: Inativação do $C$. perfringens e c. totais na desinfecção com cloro para os modelos de Hom e Watson respectivamente.

Observa-se que para os CT estudados, a inativação de coliformes totais apresentou-se mais pronunciada do que para o $C$. perfringens, visto que a inativação dos coliformes totais ultrapassou $5 \log$ de remoção enquanto para Clostridium perfringens não foi alcançado 1,5 $\log$ de inativação, ficando evidenciado, portanto, o caráter mais resistente das bactérias formadoras de esporos à desinfecção com cloro.

Verificou-se que o aumento no valor de CT não proporcionou maior log de inativação para as bactérias estudadas. A inativação de $C$. perfringens para CT de 96 e $954 \mathrm{mgCl}_{2} / \mathrm{L}$.min foi de, respectivamente, 0,55 e 1,26 log e para coliformes totais e mesmos CT a remoção foi de 3,99 e 5,06 log, respectivamente.

A equação (5.2) foi a que forneceu maior coeficiente de correlação $\left(\mathrm{R}^{2}=0,78064\right)$ para o C. perfringens nos ensaios de desinfecção aplicando-se apenas cloro.

$$
\frac{N}{N o}=\exp \left(-0,7063 . C l_{\text {aplicado }}^{4,5680} \cdot t^{-4,2318}\right)
$$


Para coliformes totais a equação (5.3) foi a que apresentou o melhor ajuste $\left(\mathrm{R}^{2}=\right.$ $0,81233)$.

$$
\frac{N}{N o}=\exp \left(-4,4278 . C l_{\text {aplicado }}^{-0,7035} . t\right)
$$

\subsubsection{Inativação de $C$. perfringens e coliformes totais na desinfecção sequencial de cloro seguido de UV}

Os valores dosados de cloro não estão claramente presentes nos gráficos de cinética para a desinfecção sequencial devido à impossibilidade de se conjugar diferentes unidades de desinfecção no mesmo eixo, haja visto que a unidade de dosagem de cloro é em mg/L e a unidade de emissão de radiação UV é em $\mathrm{Wh} / \mathrm{m}^{3}$. Isso impediria a colocação desses valores no mesmo eixo e, consecutivamente, as doses de desinfetantes utilizados na desinfecção sequencial.

Para solucionar esse problema, a dose com valor de $0 \mathrm{Wh} / \mathrm{m}^{3}$ refere-se à aplicação de cloro de $10 \mathrm{mgCl}_{2} / \mathrm{L}$ por $10 \mathrm{~min}$ de tempo de contato no ensaio I. No ensaio II, a dose de 0 $\mathrm{Wh} / \mathrm{m}^{3}$ refere-se à dose aplicada de cloro de $10 \mathrm{mgCl}_{2} / \mathrm{L}$ por $20 \mathrm{~min}$, e o mesmo se aplica até o ensaio VIII. Não há gráfico para o ensaio IX, pois para todas as bactérias estudadas foi alcançado 100 \% de eficiência de inativação, não restando assim, sobreviventes para aplicar a cinética.

Portanto, para a Figura 5.11, referente ao ensaio I, e para os demais ensaios em que somente foi avaliada a desinfecção sequencial (excetuando I-B), foi adotado esse recurso com o objetivo de se colocar no mesmo eixo as doses de desinfetantes nas quais as amostras foram expostas.

Na Figura 5.11 pode-se observar a diferença na eficiência de desinfecção quando foi utilizada a desinfecção sequencial com cloro seguido de radiação UV (I-A) e apenas radiação UV (I-B).

Nota-se que foi atingido 2,47 log de inativação de C. perfringens após ter passado pela maior dose de UV recebida $\left(10 \mathrm{Wh} / \mathrm{m}^{3}\right.$ ) (Figura $\left.5.11 \mathrm{I}-\mathrm{A}\right)$. No entanto, com a mesma exposição ao UV para a mesma amostra, mas sem ter sido clorada (Figura 5.11 I-B), a inativação desta bactéria atinge o valor de 1,5 log, evidenciando a potencialização da ação desinfetante sobre o mesmo organismo quando é aplicado o cloro seguido de radiação UV.

Observa-se o mesmo padrão para as demais bactérias estudadas, ou seja, quando é aplicada a desinfecção sequencial ocorre uma melhoria na ação desinfetante sobre os microrganismos, produzindo um aumento de remoção de praticamente 1 log para coliformes 
totais e $0,7 \log$ para E. coli.

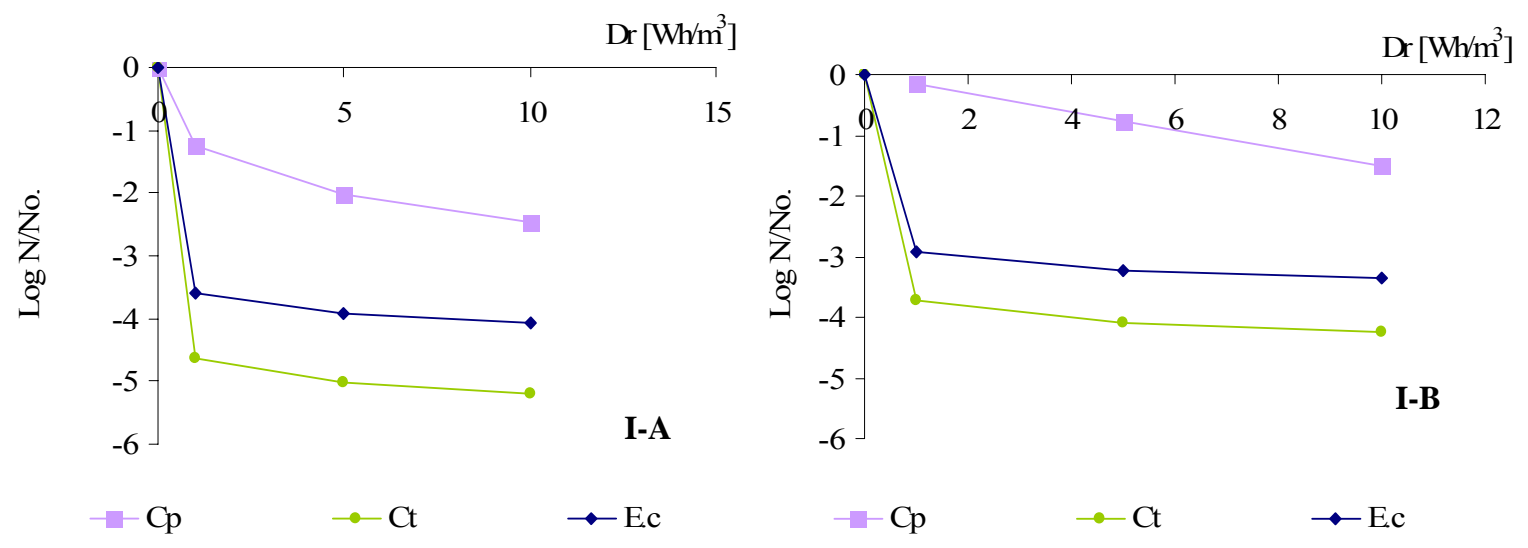

Figura 5.11: Inativação de $C$. perfringens, $E$. coli e coliformes totais para os ensaios de desinfecção sequencial - cloro seguido de UV (I-A), e para a desinfecção apenas com UV (I-B) do experimento I.

As equações (5.4) - experimento I-A - e (5.5) - experimento I-B - foram obtidas considerando que a inativação siga o modelo de Watson. Os ajustes dos dados experimentais foram muito bons com $\mathrm{R}^{2}$ de 0,9882 e 0,9934 para as equações (5.4) e (5.5), respectivamente.

$$
\begin{aligned}
\frac{N}{N o} & =\exp \left(-2,8505 \cdot D_{r}^{0,3004}\right) \\
\frac{N}{N o} & =\exp \left(-0,3684 \cdot D_{r}^{0,9739}\right)
\end{aligned}
$$

No ensaio I, observa-se que, na desinfecção sequencial, a constante de decaimento do Clostridium é mais de 7 vezes maior quando sujeita a $10 \mathrm{mgCl}_{2} / \mathrm{L}$ para 10 minutos de tempo de contato como o cloro e $10 \mathrm{Wh} / \mathrm{m}^{3}$ do que em relação a desinfecção sujeita somente de 10 $\mathrm{Wh} / \mathrm{m}^{3}$ de UV.

Define-se também para este trabalho a equação padrão da desinfecção sequencial de cloro seguido de UV, somente UV, e mais adiante no texto, para a desinfecção sequencial de ozônio seguido de UV conforme a equação (5.6).

$$
\frac{N}{N o}=\exp \left(-K \cdot D_{r}^{n}\right)
$$

K e n são coeficientes encontrados na regressão dos dados do logaritmo da fração sobrevivente de microrganismos estudados em cada fase da desinfecção, ou seja, após a cloração e cada dose de UV. 
$\mathrm{O}$ coeficiente $\mathrm{K}$ representa a constante de decaimento da fração sobrevivente de microrganismos estudados, e $\mathrm{n}$ representa a curvatura das curvas de decaimento.

Os valores de todos os coeficientes obtidos na regressão dos dados estão colocados na Tabela 5.16 para o C. perfringens, na Tabela 5.17 para coliformes totais e na Tabela 5.18 para E. coli.

Sobre os coliformes totais, observa-se pelas Tabelas 5.17 e 5.18, que a constante de decaimento destes microrganismos é semelhante a da $E$. coli, sendo aproximadamente 1,25 vezes maior para a desinfecção sequencial.

No experimento II (Figura 5.12), observa-se que a constante de decaimento do $C$. perfringens é 6,32 vezes menor do que a dos coliformes totais, enfatizando a resistência das bactérias anaeróbias esporuladas.

Comparando os ensaios II e III (Figura 5.12) é possível observar que a inativação dos coliformes totais foi maior quando o tempo de contato com o cloro foi aumentado de 20 para $30 \mathrm{~min}$. No ensaio II, foi atingido 4,7 log de inativação após a sujeição à maior dose de UV $\left(10 \mathrm{Wh} / \mathrm{m}^{3}\right)$. Por outro lado, no ensaio III atingiu-se mais de $5 \log$ de inativação. Todavia, um padrão diferente foi observado para o $C$. perfringens, que no ensaio II atingiu 2,7 log e no ensaio III não passou de 1,1 log. Mostrou-se com isso, que com a mesma dose de cloro, o aumento no tempo de contato não foi favorável para inativação do C. perfringens.

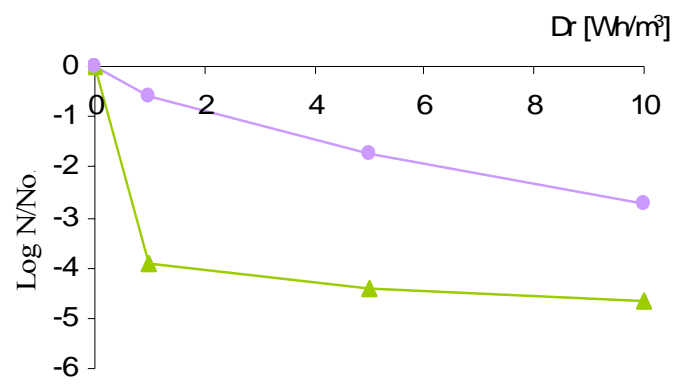

II

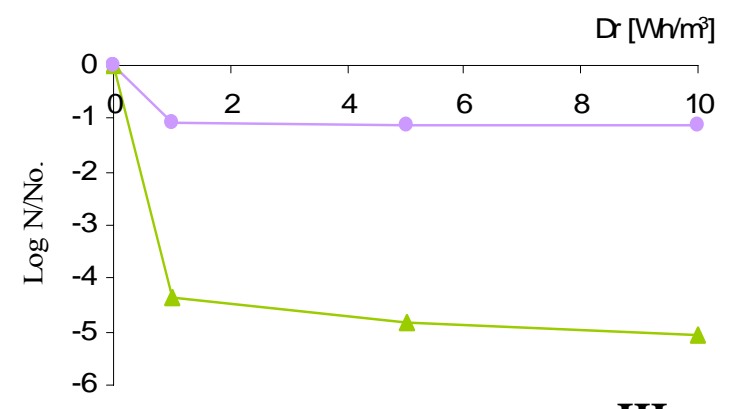

III
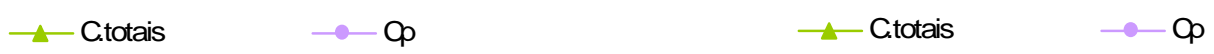

Figura 5.12: Inativação de C. perfringens e coliformes totais nos ensaios II e III.

$\mathrm{Na}$ Figura 5.13, observam-se os ensaios nos quais foram aplicados $20 \mathrm{mgCl}_{2} / \mathrm{L}$, variando o tempo de contato entre 10, 20 e $30 \mathrm{~min}$, - ensaios IV, V e VI, respectivamente. Observa-se que houve no ensaio $\mathrm{V}$, correspondente a 20 minutos de tempo de contato com o cloro antecedente a radiação UV, maior eficiência para o $C$. perfringens seguido de 30 minutos de contato. Para os coliformes totais, a eficiência foi decrescente quando relacionada 
com o tempo de contato com o cloro. Assim, 10 minutos de contato com esse desinfetante forneceu melhor eficiência que 20 e 30 minutos. A melhor eficiência para o menor tempo de contato com $20 \mathrm{mgCl}_{2} / \mathrm{L}$ pode advir do fato que, no ensaio IV, a concentração de sólidos suspensos totais (SST) foi menor quando comparada com os ensaios V e VI.

No ensaio IV, a concentração de SST foi de $38 \mathrm{mg} / \mathrm{L}$ na amostra clorada sujeita à radiação UV. Próximo ao valor recomendado para desinfecção com radiação ultravioleta (30 $\operatorname{mgSST} / \mathrm{L})$.
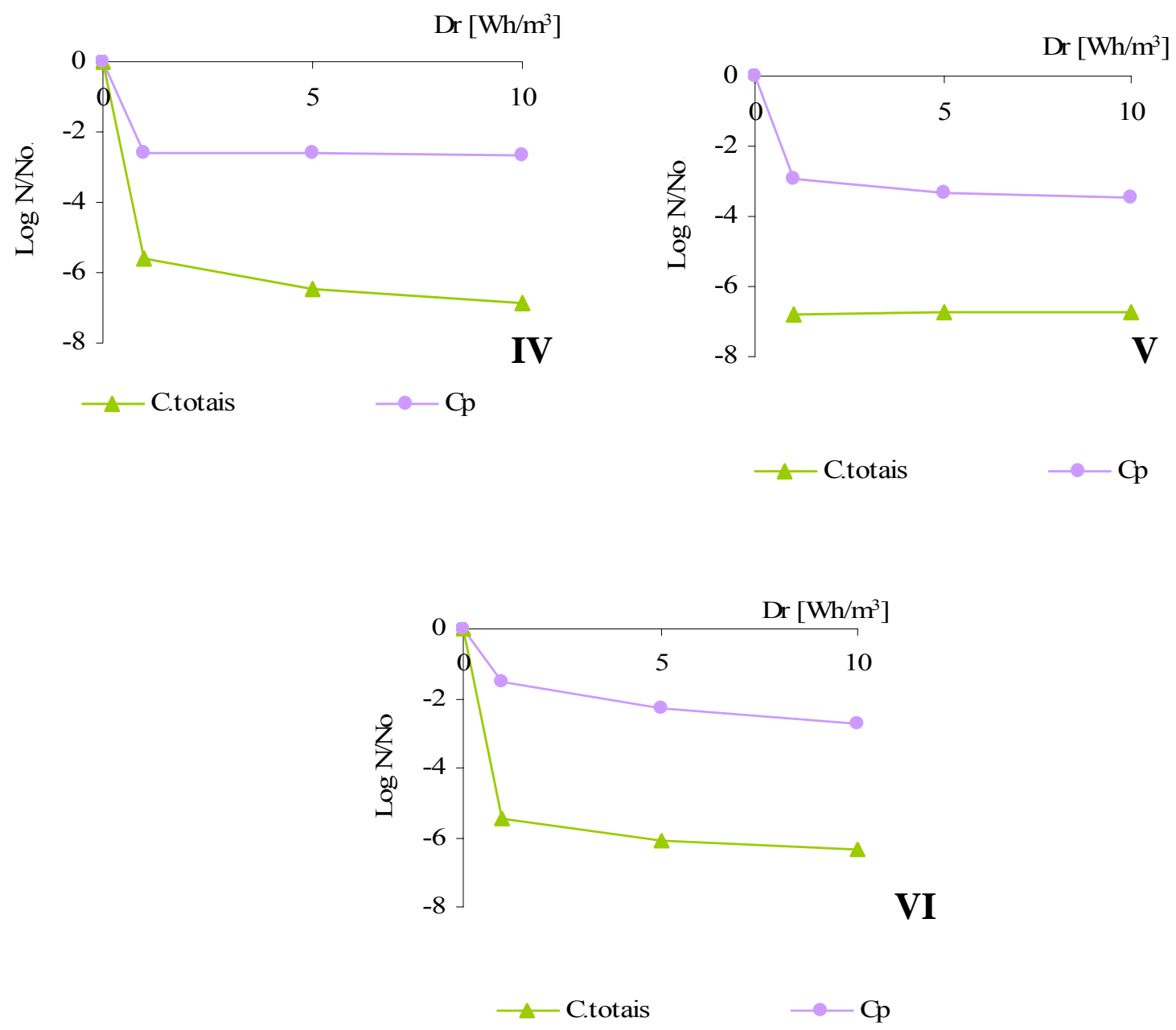

Figura 5.13: Inativação de C. perfringens e coliformes totais nos ensaios IV, V e VI.

Para a desinfecção sequencial, em que se aplicou $30 \mathrm{mgCl}_{2} / \mathrm{L}$ antes da radiação UV nos ensaios VII e VIII, observou-se que o aumento do tempo de contato com o agente químico foi favorável para aumentar a eficiência na inativação tanto do $C$. perfringens quanto dos coliformes totais. Houve um aumento de quase um log de remoção dessas bactérias 
quando se aumentou de 10 para 20 minutos o tempo de contato com o cloro (Figura 5.14).
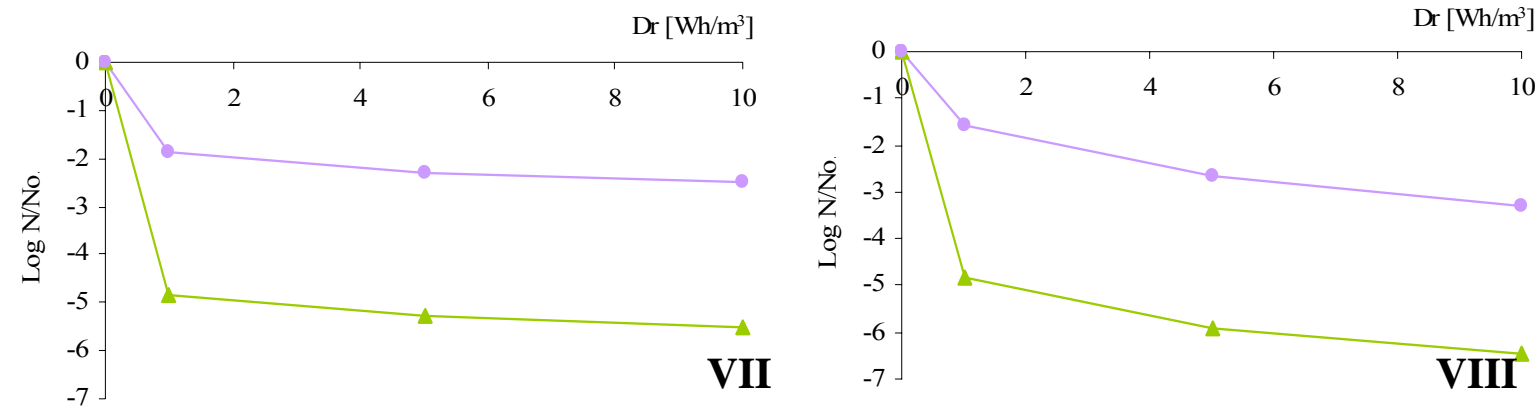

- C.totais

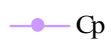

$\rightarrow$ C.totais

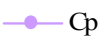

Figura 5.14: Inativação de C. perfringens e coliformes totais nos ensaios VII e VIII.

Tabela 5.16: Valores dos parâmetros cinéticos obtidos nos ensaios de desinfecção com cloroUV para C. perfringens.

\begin{tabular}{cccc}
\hline & \multicolumn{3}{|c}{ Watson } \\
\hline Experimento & $\mathrm{K}^{\prime}\left(\mathrm{m}^{3} / \mathrm{Wh}\right)$ & $\mathrm{n}$ & $\mathrm{R}^{2}$ \\
\hline I-A & 2,8506 & 0,3004 & 0,9882 \\
I-B & 0,3684 & 0,9739 & 0,9932 \\
II & 1,4238 & 0,6444 & 0,9559 \\
III & 2,4526 & 0,0228 & 0,9139 \\
IV & 5,9099 & 0,0124 & 0,0502 \\
V & 6,7021 & 0,0798 & 0,9933 \\
VI & 3,4454 & 0,2620 & 0,7968 \\
VII & 4,3322 & 0,1202 & 0,9139 \\
VIII & 3,6669 & 0,3172 & $1 *$ \\
\hline
\end{tabular}

Nota: * A correlação foi de 1, pois haviam apenas dois dados para se fazer a regressão no conjunto de dados.

Tabela 5.17: Valores dos parâmetros cinéticos obtidos nos ensaios de desinfecção com cloroUV para coliformes totais.

\begin{tabular}{cccc}
\hline & \multicolumn{3}{|c}{ Watson } \\
\hline Experimento & $\mathrm{K}^{\prime}\left(\mathrm{m}^{3} / \mathrm{Wh}\right)$ & $\mathrm{n}$ & $\mathrm{R}^{2}$ \\
\hline I-A & 10,6509 & 0,0517 & 0,9139 \\
I-B & 8,5878 & 0,0565 & 0,8785 \\
II & 8,9770 & 0,0790 & 0,9959 \\
III & 10,0866 & 0,0622 & 0,6489 \\
IV & 12,8881 & 0,0902 & 0,6139 \\
V & 15,6295 & $-0,0055$ & 0,9139 \\
VI & 12,5578 & 0,0676 & 0,4619 \\
VII & 11,1552 & 0,0549 & 0,9926 \\
VIII & 11,0974 & 0,1274 & 1 \\
\hline
\end{tabular}

Nota: * A correlação foi de 1, pois haviam apenas dois dados para se fazer a regressão no conjunto de dados. 
Tabela 5.18: Valores dos parâmetros cinéticos obtidos nos ensaios de desinfecção com cloro e UV para E. coli.

\begin{tabular}{cccc}
\hline & \multicolumn{3}{c}{ Watson } \\
Experimento & $\mathrm{K}^{\prime}\left(\mathrm{m}^{3} / \mathrm{Wh}\right)$ & $\mathrm{n}$ & $\mathrm{R}^{2}$ \\
\hline $\mathrm{I}-\mathrm{A}$ & 8,3077 & 0,0527 & 0,9939 \\
$\mathrm{I}-\mathrm{B}$ & 6,7341 & 0,0600 & 0,9139 \\
\hline
\end{tabular}

\subsubsection{Variação da Inativação dos microrganismos em relação ao tempo de contato com o cloro}

\subsection{C. perfringens}

Observa-se na Figura 5.15, de uma maneira geral, que o aumento do tempo de contato para 30 minutos não garantiu melhor desinfecção quando aplicado 10 ou $20 \mathrm{mgCl} / \mathrm{L}$ (gráficos A e B).

$\left[\mathrm{Cl}_{2}\right]$ de $10 \mathrm{mg} / \mathrm{L}$

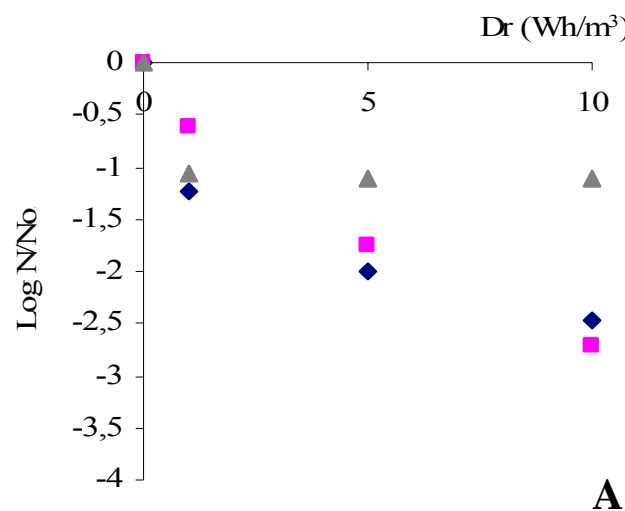

$\left[\mathrm{C}_{2}\right]$ de $20 \mathrm{mg} / \mathrm{L}$

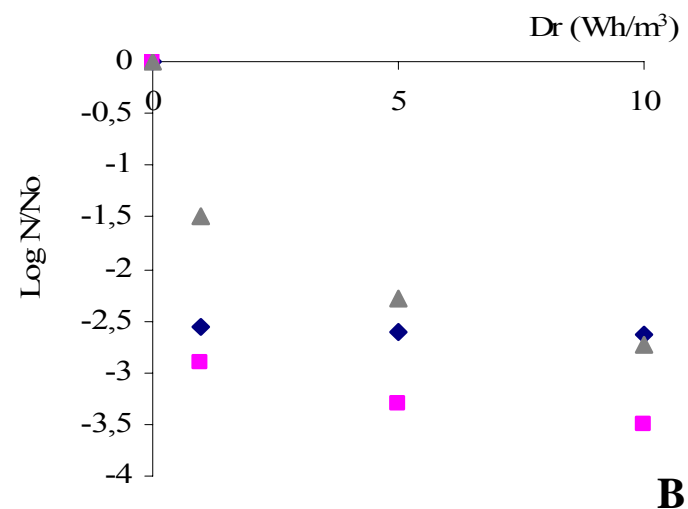
$-10 \mathrm{~min} \quad 20 \mathrm{~min} \triangle 30 \mathrm{~min}$
$\bullet 10 \mathrm{~min}$
- $20 \mathrm{~min}$
$30 \mathrm{~min}$

$\left[\mathrm{Cl}_{2}\right]$ de $30 \mathrm{mg} / \mathrm{L}$

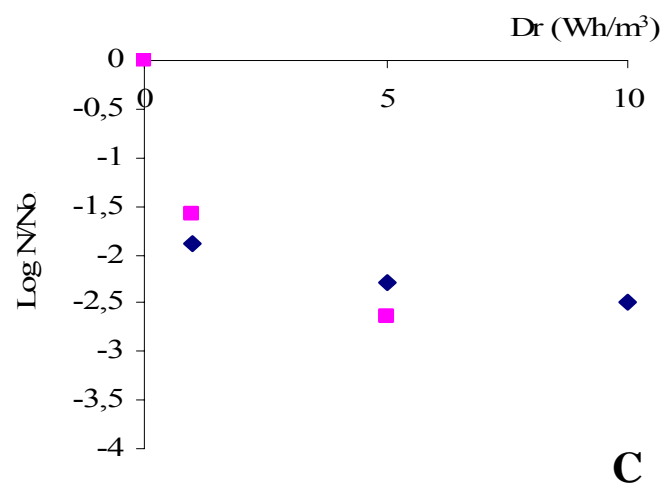

$\bullet 10 \mathrm{~min} \quad 20 \mathrm{~min}$

Figura 5.15: Influência do tempo de contato do cloro na inativação de $C$. perfringens na desinfecção sequencial com cloro seguido de radiação UV. 
Observa-se que a eficiência de inativação para tempo de contato de 10 minutos com o cloro (Figura 5.15 (A)), seguido de doses de UV de 1 e $5 \mathrm{Wh} / \mathrm{m}^{3}$, foi maior quando comparada com tempos de contato de 20 e 30 minutos com cloro. Na dose superior de UV, os tempos de contato de 10 e 20 minutos atingem mais de 2,5 $\log$ de inativação de $C$. perfringens, enquanto que na exposição de 30 minutos atingiu apenas 1 log. Além disso, para a exposição de 30 minutos com cloro, o aumento na dose de radiação UV não favoreceu o aumento da inativação dessas bactérias.

Quando aplicado $20 \mathrm{mgCl}_{2} / \mathrm{L}$ (B) em 20 minutos de contato com o cloro, ocorreu melhor inativação do que ao contato de 10 e 30 minutos.

Em C, a inativação para 30 minutos de contato com o cloro não consta no gráfico, pois ocorreu $100 \%$ de inativação de $C$. perfringens. Para a menor dose de radiação ultravioleta $\left(1 \mathrm{Wh} / \mathrm{m}^{3}\right) 10$ minutos de exposição com o cloro forneceu remoção superior àquela observada em 20 minutos de contato.

\subsection{Coliformes totais}

$\mathrm{Na}$ Figura 5.16, gráfico A, a eficiência para 10 minutos de contato com o cloro foi maior ou igual quando comparada com o tempo de contato de 20 e 30 minutos. Em B, na menor dose de UV (1 Wh/m $\left.\mathrm{m}^{3}\right), 20$ minutos de contato com o cloro já atingiu a melhor inativação. Em $\mathrm{C}$, quando se aplicam $30 \mathrm{mgCl}_{2} / \mathrm{L}$, o aumento no tempo de contato com o cloro e o aumento nas doses de UV intensificam a remoção de coliformes totais. 
$\left[\mathrm{C}_{2}\right]$ de $10 \mathrm{mg} / \mathrm{L}$

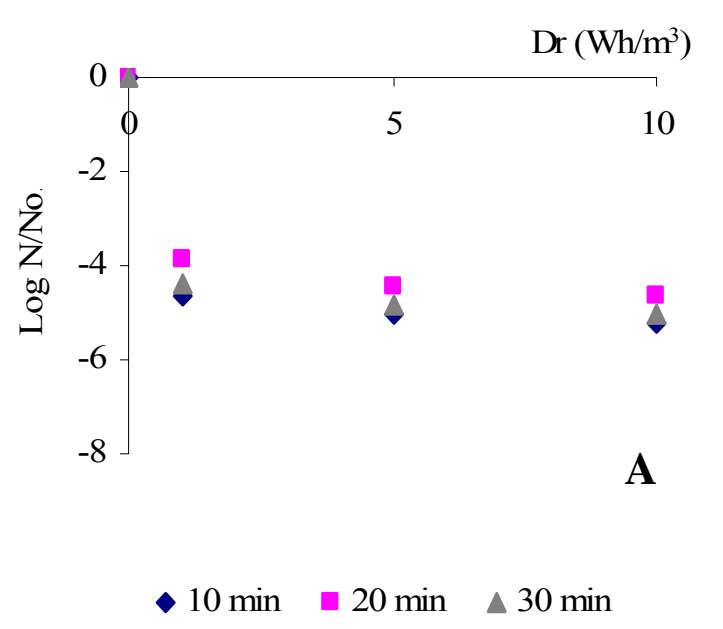

$\left[\mathrm{C}_{2}\right]$ de $20 \mathrm{mg} / \mathrm{L}$

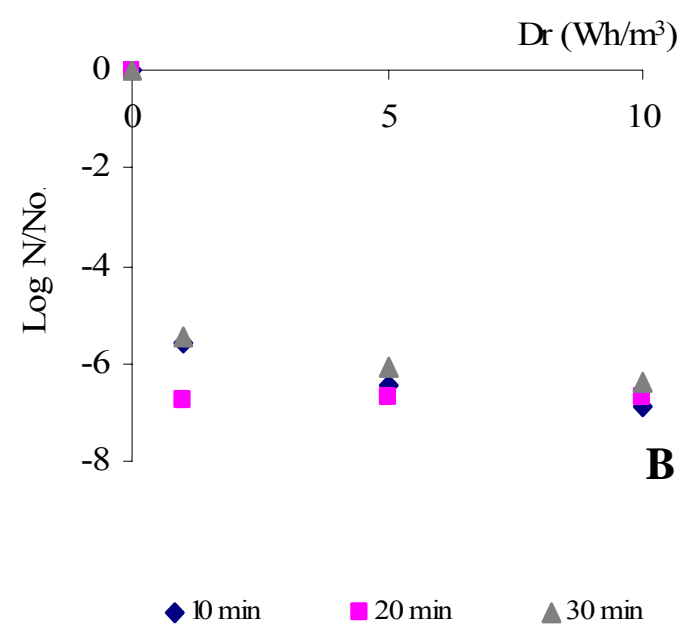

$\left[\mathrm{C}_{2}\right] \mathrm{de} 30 \mathrm{mg} / \mathrm{L}$

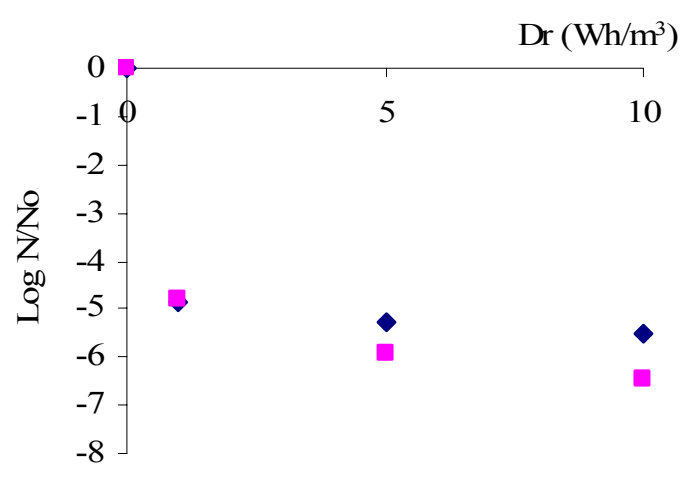

C

$\checkmark 10 \mathrm{~min} \quad 20 \mathrm{~min}$

Figura 5.16: Influência do tempo de contato do cloro na inativação de coliformes totais na desinfecção sequencial com cloro seguido de radiação UV.

\subsubsection{Relação entre inativação de microrganismos indicadores e SST}

$\mathrm{Na}$ Tabela 5.19 estão apresentados os valores de absorbância à $254 \mathrm{~nm}$ medidos no efluente do reator UASB após a cloração para determinar os tempos de contato de radiação UV necessários para fornecer as doses recebidas requeridas.

Observa-se que a relação dos valores de absorbância em comprimento de onda de $254 \mathrm{~nm}$ com o tempo de contato é direta. O aumento da quantidade de material particulado ou dissolvido na amostra (expressa pela absorbância) faz com que seja necessário maior tempo de exposição para atingir uma certa dose. A dose recebida (Dr) leva em consideração a qualidade da água residuária a ser desinfetada. 
Tabela 5.19: Valores de absorbância, $I_{m}$, dose recebida de UV e os respectivos tempos de contato da radiação UV.

\begin{tabular}{|c|c|c|c|c|}
\hline Experimento $^{(1)}$ & $\lambda: 254 \mathrm{~nm}^{(2)}$ & $\mathrm{I}_{\mathrm{m}}^{(3)}$ & $\begin{array}{c}\mathrm{Dr}^{(4)} \\
\left(\mathrm{Wh} / \mathrm{m}^{3}\right)\end{array}$ & $\begin{array}{c}\text { Tempos de contato } \\
\text { (s) }\end{array}$ \\
\hline \multirow{3}{*}{$\mathrm{I}-\mathrm{A}\left(10 \mathrm{mgCl}_{2} / \mathrm{L}, 10 \mathrm{~min}\right)$} & \multirow{3}{*}{0,455} & \multirow{3}{*}{1,828} & 1 & 10,6 \\
\hline & & & 5 & 52,9 \\
\hline & & & 10 & 105,9 \\
\hline \multirow{3}{*}{ I-B somente UV } & \multirow{3}{*}{$0,434^{*}$} & \multirow{3}{*}{1,062} & 1 & 10,2 \\
\hline & & & 5 & 50,9 \\
\hline & & & 10 & 101,7 \\
\hline \multirow{3}{*}{ II (10mgCl $/ 2 / \mathrm{L}, 20 \mathrm{~min})$} & \multirow{3}{*}{0,588} & \multirow{3}{*}{0,811} & 1 & 13,3 \\
\hline & & & 5 & 66,6 \\
\hline & & & 10 & 133,2 \\
\hline \multirow{3}{*}{ III (10mgCl $2 / \mathrm{L}, 30 \mathrm{~min})$} & \multirow{3}{*}{0,419} & \multirow{3}{*}{1,094} & 1 & 9,9 \\
\hline & & & 5 & 49,4 \\
\hline & & & 10 & 98,8 \\
\hline \multirow{3}{*}{ IV (20mgCl $2 / \mathrm{L}, 10 \mathrm{~min})$} & \multirow{3}{*}{0,609} & \multirow{3}{*}{0,785} & 1 & 13,8 \\
\hline & & & 5 & 68,8 \\
\hline & & & 10 & 137,6 \\
\hline \multirow{3}{*}{$\mathrm{V}\left(20 \mathrm{mgCl}_{2} / \mathrm{L}, 20 \mathrm{~min}\right)$} & \multirow{3}{*}{0,855} & \multirow{3}{*}{0,566} & 1 & 19,1 \\
\hline & & & 5 & 95,4 \\
\hline & & & 10 & 190,9 \\
\hline \multirow{3}{*}{ VI (20mgCl $2 / \mathrm{L}, 30 \mathrm{~min})$} & \multirow{3}{*}{0,902} & \multirow{3}{*}{0,537} & 1 & 20,1 \\
\hline & & & 5 & 100,6 \\
\hline & & & 10 & 201,2 \\
\hline \multirow{3}{*}{ VII (30mgCl $2 / \mathrm{L}, 10 \mathrm{~min})$} & \multirow{3}{*}{0,341} & \multirow{3}{*}{1,288} & 1 & 8,4 \\
\hline & & & 5 & 41,9 \\
\hline & & & 10 & 83,9 \\
\hline \multirow{3}{*}{ VIII (30mgCl $2 / \mathrm{L}, 20 \mathrm{~min})$} & \multirow{3}{*}{0,558} & \multirow{3}{*}{0,851} & 1 & 12,7 \\
\hline & & & 5 & 63,5 \\
\hline & & & 10 & 126,9 \\
\hline \multirow{3}{*}{$\mathrm{IX}\left(30 \mathrm{mgCl}_{2} / \mathrm{L}, 30 \mathrm{~min}\right)$} & \multirow{3}{*}{0,393} & \multirow{3}{*}{1,152} & 1 & 9,4 \\
\hline & & & 5 & 46,9 \\
\hline & & & 10 & 93,7 \\
\hline
\end{tabular}

Notas: *efluente sem cloro; (1) número dado a cada experimento e sua correspondente concentração e tempo de contato com o ozônio; (2) valores de absorbância a $254 \mathrm{~nm}$ medidos para o efluente do reator UASB clorado; (3) usando a equação 4.4; (4) doses recebidas fixadas; (5) usando a equação 4.6 para as doses recebidas fixadas.

No cálculo de dose recebida de radiação UV o efeito dos SST foi considerado ao se calcular a intensidade média de radiação, a qual é dependente da absorbância em $\lambda 254 \mathrm{~nm}$. Quanto maior a concentração de SST maior a absorbância. Para suprir a maior demanda de radiação UV e manter a dose recebida constante, aumentou-se o tempo de exposição.

Nas condições em que os ensaios foram realizados e considerando as características do esgoto desinfetado, a determinação da dose de UV utilizada levou em consideração a quantidade partículas absorvedoras de radiação. Desta maneira pode-se observar nas 
FigurasFigura 5.17 e 5.18 que a inativação de microrganismos através da radiação UV ocorreu mesmo quando sujeitas à altas concentrações de sólidos suspensos totais.

Dose de $1 \mathrm{Wh} / \mathrm{m}^{3}$

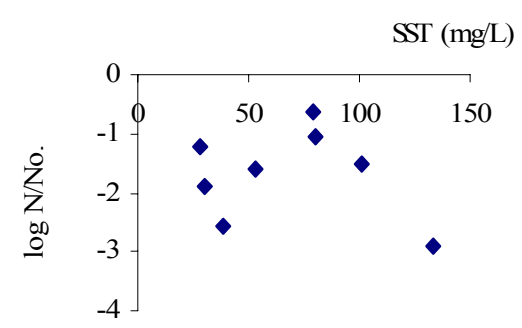

Dose de $5 \mathrm{Wh} / \mathrm{m}^{3}$

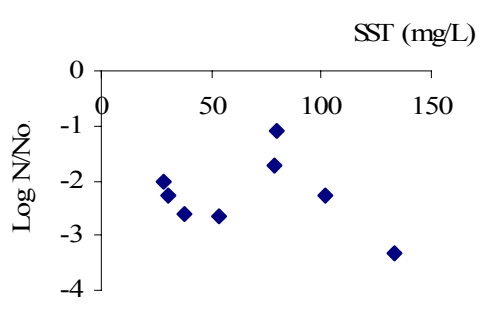

Dose de $10 \mathrm{Wh} / \mathrm{m}^{3}$

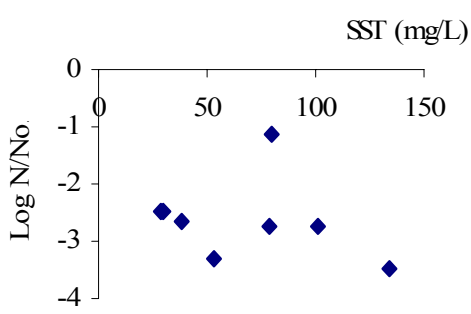

Figura 5.17: Relação entre SST e a remoção de $C$. perfringens para as doses de UV estudadas.

Dose de $1 \mathrm{Wh} / \mathrm{m}^{3}$

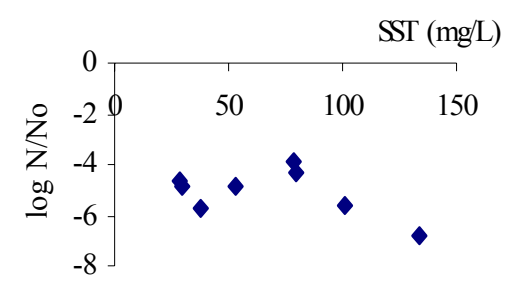

Dose de $5 \mathrm{Wh} / \mathrm{m}^{3}$

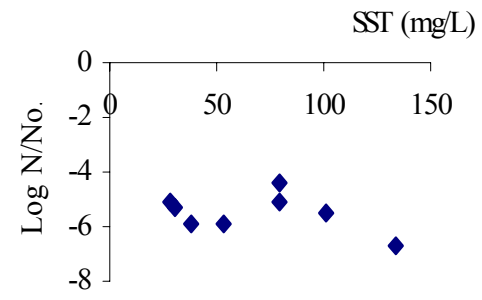

Dose de $10 \mathrm{Wh} / \mathrm{m}^{3}$

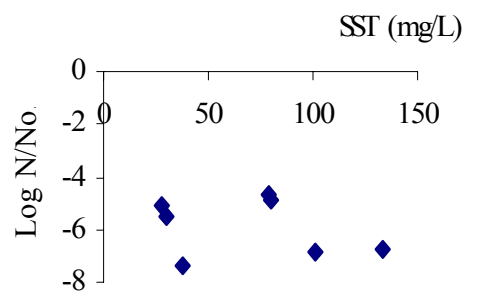

Figura 5.18: Relação entre SST e a remoção de coliformes totais para as doses de UV estudadas.

\subsection{Calibração do gerador de ozônio}

A calibração do gerador de ozônio forneceu as produções de gás listadas na Tabela 5.20. Com as produções e suas vazões respectivas de gás, foram compiladas as curvas de calibração do equipamento gerador de ozônio. 
Tabela 5.20: Produção do gerador de ozônio em função da vazão de gás e de tensão elétrica.

Tensão $100 \%$

\begin{tabular}{ccc}
\hline Vazão & $\mathrm{P}\left(\mathrm{g} \mathrm{O}_{3} / \mathrm{h}\right)$ & $\mathrm{P}(\mathrm{mg} / \mathrm{L})$ \\
\hline 240 & 3,07814 & 58,2981 \\
180 & 2,802603 & 53,0796 \\
108 & 1,81067 & 34,293 \\
0 & 0 & 0 \\
\hline
\end{tabular}

Tensão $80 \%$

\begin{tabular}{ccc}
\hline Vazão & $\mathrm{P}\left(\mathrm{g} \mathrm{O}_{3} / \mathrm{h}\right)$ & $\mathrm{P}(\mathrm{mg} / \mathrm{L})$ \\
\hline 240 & 2,101952 & 39,8097 \\
180 & 1,566624 & 29,6709 \\
108 & 1,405238 & 26,61435 \\
60 & 0,834483 & 15,8046 \\
0 & 0 & 0 \\
\hline
\end{tabular}

Tensão $60 \%$

\begin{tabular}{ccc}
\hline Vazão & $\mathrm{P}\left(\mathrm{g} \mathrm{O}_{3} / \mathrm{h}\right)$ & $\mathrm{P}(\mathrm{mg} / \mathrm{L})$ \\
\hline 240 & 1,424919 & 26,9871 \\
180 & 1,039167 & 19,6812 \\
108 & 0,936825 & 17,7429 \\
60 & 0,606181 & 11,4807 \\
0 & 0 & 0 \\
\hline
\end{tabular}

Tensão 40\%

\begin{tabular}{ccc}
\hline Vazão & $\mathrm{P}\left(\mathrm{g} \mathrm{O}_{3} / \mathrm{h}\right)$ & $\mathrm{P}(\mathrm{mg} / \mathrm{L})$ \\
\hline 240 & 0,881718 & 16,6992 \\
180 & 0,566819 & 10,7352 \\
108 & 0,488094 & 9,2442 \\
60 & 0,204684 & 3,8766 \\
0 & 0 & 0 \\
\hline
\end{tabular}

Para este trabalho, na curva de calibração, a produção máxima de ozônio atingiu 3,08 g $\mathrm{O}_{3} / \mathrm{h}$, valor inferior ao informado pelo fabricante de $7 \pm 0,7 \mathrm{~g} \mathrm{O}_{3} / \mathrm{h}$. 
Na Figura 5.19 encontram-se as curvas de calibração de ozônio obtidas no presente trabalho.

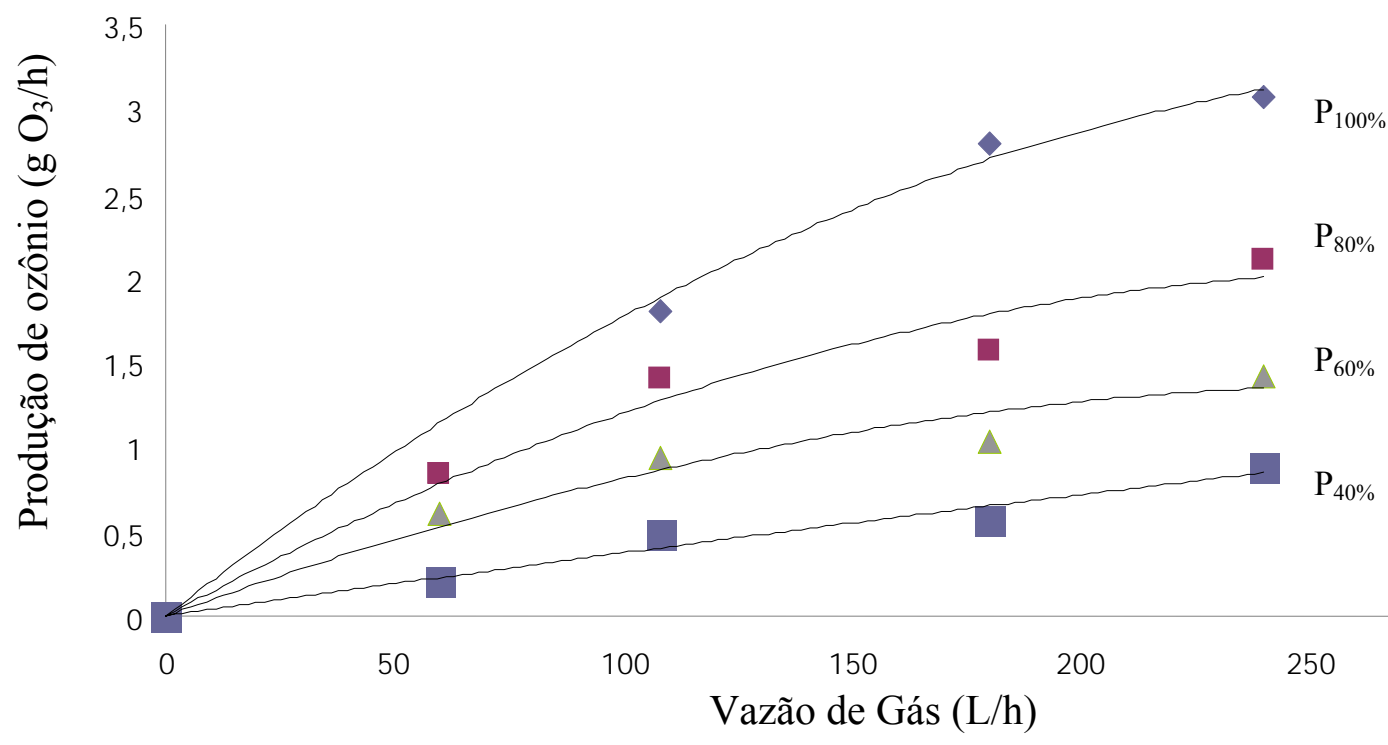

Figura 5.19: Curvas de calibração para a relação entre a produção de ozônio ( $\left.\mathrm{g} \mathrm{O}_{3} / \mathrm{h}\right)$ e a vazão de gás $(\mathrm{L} / \mathrm{h})$.

Aos valores observados de produção em função da vazão foram ajustadas as equações (5.7) a (5.10):

$$
\begin{array}{ll}
\mathrm{P}_{100 \%}=0,0211 \mathrm{Q} & \mathrm{R}^{2}=0,9971 \\
\mathrm{P}_{80 \%}=0,0146 \mathrm{Q} & \mathrm{R}^{2}=0,9699 \\
\mathrm{P}_{60 \%}=0,01 \mathrm{Q} & \mathrm{R}^{2}=0,9611 \\
\mathrm{P}_{40 \%}=0,0030 \mathrm{Q} & \mathrm{R}^{2}=0,9649
\end{array}
$$

$\mathrm{P}_{\mathrm{i} \%}$ : produção de gás, para a dada tensão 'i', em g $\mathrm{O}_{3} / \mathrm{L}$;

i: \% de tensão (40, 60, 80 e 100);

Q: vazão de gás aplicada, $\mathrm{L} / \mathrm{h}$;

$\mathrm{R}^{2}$ : Coeficiente de correlação ao quadrado. 
$\mathrm{Na}$ Tabela 5.21 encontra-se a produção de ozônio correspondente às dosagens e aos tempos de contato utilizados nos ensaios de desinfecção, sendo que o volume de efluente usado na ozonização sempre foi de 15,1L.

Tabela 5.21: Valores de Produção, dosagens e tempos de contato usados.

\begin{tabular}{ccccc}
\hline Experimento & $\mathrm{t}(\mathrm{min})$ & $\mathrm{D}(\mathrm{mg} / \mathrm{L})$ & $\mathrm{P}(\mathrm{g} / \mathrm{h})$ & Vazão $(\mathrm{L} / \mathrm{h})$ \\
\hline \hline 0-A & 10 & 5,7 & 0,515 & 132 \\
I & 10 & 5,7 & 0,515 & 132 \\
II & 20 & 5,7 & 0,257 & 66 \\
III-A & 30 & 5,4 & 0,164 & 42 \\
III-B & 30 & 10,4 & 0,164 & 42 \\
IV & 10 & 11,4 & 0,960 & 96 \\
V-A & 20 & 11,4 & 0,515 & 132 \\
V-B & 20 & 10,8 & 0,515 & 132 \\
VI & 30 & 15,9 & 0,328 & 84 \\
VII & 10 & 16,5 & 1,440 & 144 \\
VIII & 20 & 17,0 & 0,749 & 192 \\
IX & 30 & & 0,515 & 132 \\
\hline
\end{tabular}

\subsection{Balanço de massa obtido nos ensaios com ozônio}

Para os ensaios realizados com ozônio, encontram-se na Tabela 5.22 os resultados do balanço de massa de cada experimento.

Tabela 5.22: Resultados do balanço de massa obtido nos ensaios com ozônio.

\begin{tabular}{|c|c|c|c|c|c|c|c|c|c|c|c|c|}
\hline 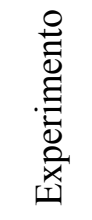 & $\begin{array}{c}\mathrm{P} \\
(\mathrm{g} / \mathrm{h})\end{array}$ & $\underset{(\mathrm{mg} / \mathrm{L})}{\mathrm{P}}$ & $\begin{array}{c}\mathrm{M}_{\mathrm{A}} \\
(\mathrm{mg})\end{array}$ & $\begin{array}{c}\mathrm{M}_{\mathrm{T}} \\
(\mathrm{mg})\end{array}$ & $\begin{array}{c}\mathrm{M}_{\text {OFF- }} \\
\text { GAS } \\
(\mathrm{mg})\end{array}$ & $\begin{array}{c}\mathrm{M}_{\mathrm{R}} \\
(\mathrm{mg})\end{array}$ & $\begin{array}{c}\mathrm{M}_{\mathrm{C}} \\
(\mathrm{mg})\end{array}$ & 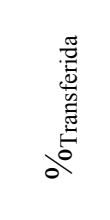 & 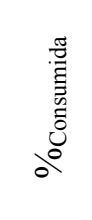 & $\begin{array}{c}{\left[\mathrm{O}_{3}\right]_{\text {OFF- }}} \\
\mathrm{GAS} \\
(\mathrm{mg} / \mathrm{L})\end{array}$ & $\begin{array}{c}{\left[\mathrm{O}_{3}\right]_{\mathrm{R}}} \\
(\mathrm{mg} / \mathrm{L})\end{array}$ & $\begin{array}{c}{\left[\mathrm{O}_{3}\right]_{\mathrm{C}}} \\
(\mathrm{mg} / \mathrm{L})\end{array}$ \\
\hline $\mathrm{O}-\mathrm{A}$ & 0,505 & 5,6 & 84,2 & 84,2 & 0,0 & 4,1 & 80,1 & 100,0 & 95,2 & 0,00 & 0,27 & 5,3 \\
\hline I & 0,505 & 5,6 & 84,2 & 84,1 & 0,1 & 3,3 & 80,8 & 99,9 & 95,9 & 0,01 & 0,22 & 5,4 \\
\hline II & 0,252 & 5,6 & 84,0 & 83,2 & 0,8 & 7,9 & 75,3 & 99,0 & 89,7 & 0,05 & 0,52 & 5,0 \\
\hline $\begin{array}{c}\text { III- } \\
\text { A }\end{array}$ & 0,168 & 5,6 & 84,0 & 83,4 & 0,6 & 8,9 & 74,5 & 99,3 & 88,7 & 0,04 & 0,59 & 5,0 \\
\hline III-B & 0,168 & 5,6 & 84,0 & 82,3 & 1,7 & 3,2 & 79,2 & 98,0 & 94,2 & 0,11 & 0,21 & 5,3 \\
\hline IV & 0,954 & 10,5 & 159,0 & 138,8 & 20,2 & 4,4 & 134,5 & 87,3 & 84,6 & 1,34 & 0,29 & 8,9 \\
\hline V-A & 0,505 & 11,1 & 168,3 & 168,3 & 0,0 & 5,0 & 163,4 & 100,0 & 97,0 & 0,00 & 0,33 & 10,8 \\
\hline V-B & 0,505 & 11,1 & 168,3 & 154,8 & 13,6 & 2,4 & 152,4 & 91,9 & 90,5 & 0,90 & 0,16 & 10,0 \\
\hline VI & 0,337 & 11,2 & 168,5 & 168,5 & 0,0 & 10,3 & 158,2 & 100,0 & 93,9 & 0,00 & 0,68 & 10,4 \\
\hline VII & 1,431 & 15,8 & 238,5 & 237,9 & 0,6 & 21,0 & 216,9 & 99,7 & 90,9 & 0,04 & 1,39 & 14,4 \\
\hline VIII & 0,757 & 16,7 & 252,3 & 243,0 & 9,3 & 9,4 & 233,6 & 96,3 & 92,6 & 0,62 & 0,62 & 15,5 \\
\hline IX & 0,505 & 16,7 & 252,5 & 221,6 & 30,9 & 8,2 & 213,4 & 87,7 & 84,5 & 2,05 & 0,54 & 14,1 \\
\hline
\end{tabular}

Legenda: $\mathrm{P}$ : produção de ozônio; $\mathrm{M}_{\mathrm{A}}$ : massa de ozônio aplicada; $\mathrm{M}_{\mathrm{T}}$ : massa de ozônio transferida; $\mathrm{M}_{\text {off-gas }}$ : massa de ozônio no off-gas; $\mathrm{M}_{\mathrm{R}}$ : massa de ozônio residual; $\mathrm{M}_{\mathrm{C}}$ : massa de ozônio consumida (equação 4.14); $\left[\mathrm{O}_{3}\right]_{\text {off-gas: }}$ : concentração de ozônio no off-gas; $\left[\mathrm{O}_{3}\right]_{\text {Residual: }}$ concentração de ozônio residual; $\left[\mathrm{O}_{3}\right]_{\mathrm{C}}$ : concentração de ozônio consumido. 


\subsection{Ensaios de desinfecção com ozônio seguido de radiação ultravioleta}

Foi feita a caracterização físico-química e microbiológica do efluente anaeróbio bruto e do ozonizado medindo-se: $\mathrm{pH}$, temperatura, alcalinidade total, sólidos totais, sólidos suspensos totais, ozônio residual e do off-gas e exames de Escherichia coli, coliformes totais e Clostridium perfringens. Para o efluente ozonizado submetido à desinfecção com radiação $\mathrm{UV}$, foram feitos apenas os exames microbiológicos.

Nas TabelasTabela 5.23 a 5.34 está apresentada a caracterização físico-química e microbiológica do efluente bruto (EB) proveniente da saída do reator UASB, do esgoto desinfetado com ozônio (EO) do esgoto desinfetado com ozônio seguido de UV (EUV).

Tabela 5.23: Características físico-químicas e microbiológicas do esgoto no experimento 0 .

\begin{tabular}{|c|c|c|c|c|c|c|c|c|}
\hline \multirow[b]{2}{*}{ Variáveis } & \multicolumn{5}{|c|}{ Experimento $0-\mathrm{A}(5,6 ; 10)^{(1)}$} & \multicolumn{3}{|c|}{ Experimento 0-B (somente UV) } \\
\hline & $\mathrm{EB}^{(2)}$ & $\mathrm{EO}^{(3)}$ & $\begin{array}{c}\mathrm{EUV}_{1} \\
\mathrm{comO}_{3} \\
{[1} \\
\left.\mathrm{Wh} / \mathrm{m}^{3}\right]\end{array}$ & $\begin{array}{c}\mathrm{EUV}_{2} \\
\mathrm{comO}_{3} \\
{[3} \\
\left.\mathrm{Wh} / \mathrm{m}^{3}\right]\end{array}$ & $\begin{array}{c}\mathrm{EUV}_{3} \\
\mathrm{comO}_{3} \\
{[5} \\
\left.\mathrm{Wh} / \mathrm{m}^{3}\right]\end{array}$ & $\begin{array}{c}\mathrm{EUV}_{1} \\
\mathrm{semO}_{3} \\
{[1} \\
\left.\mathrm{Wh} / \mathrm{m}^{3}\right]\end{array}$ & $\begin{array}{c}\mathrm{EUV}_{2} \\
\mathrm{semO}_{3} \\
{[3} \\
\left.\mathrm{Wh} / \mathrm{m}^{3}\right]\end{array}$ & $\begin{array}{c}\mathrm{EUV}_{3} \\
\mathrm{semO}_{3} \\
{[5} \\
\left.\mathrm{Wh} / \mathrm{m}^{3}\right]\end{array}$ \\
\hline $\mathrm{T}\left({ }^{\circ} \mathrm{C}\right)$ & 23 & 23 & & & & & & \\
\hline $\mathrm{pH}$ & 6,48 & 7,23 & & & & & & \\
\hline $\begin{array}{l}\text { Alcalinidade } \\
\text { Total } \\
\left(\mathrm{mgCaCO}_{3} / \mathrm{L}\right)\end{array}$ & 179 & 185 & & & & & & \\
\hline $\mathrm{ST}(\mathrm{mg} / \mathrm{L})$ & 350 & 330 & & & & & & \\
\hline $\mathrm{SST}(\mathrm{mg} / \mathrm{L})$ & 64 & 35 & & & & & & \\
\hline DQO (mg/L) & 436 & 408 & & & & & & \\
\hline $\begin{array}{l}\text { E. coli } \\
\text { (UFC/100mL) }\end{array}$ & $1,2 \times 10^{6}$ & $1,5 \times 10^{6}$ & $7 \times 10^{3}$ & $8 \times 10^{1}$ & $8 \times 10^{1}$ & $5 \times 10^{3}$ & $2,2 \times 10^{2}$ & $2 \times 10^{2}$ \\
\hline $\begin{array}{l}\text { Coliformes } \\
\text { totais } \\
\text { (UFC/100mL) }\end{array}$ & $2,6 \times 10^{7}$ & $1,1 \times 10^{7}$ & $1,4 \times 10^{5}$ & $7 \times 10^{2}$ & $2 \times 10^{2}$ & $2 \times 10^{5}$ & $4 \times 10^{3}$ & $7,4 \times 10^{3}$ \\
\hline $\begin{array}{l}\text { C. perfringens } \\
(\mathrm{NMP} / 100 \mathrm{~mL})\end{array}$ & $5 \times 10^{4}$ & $1,7 \times 10^{4}$ & $1,4 \times 10^{4}$ & $7 \times 10^{2}$ & $1,3 \times 10^{2}$ & $1,9 \times 10^{3}$ & $1,3 \times 10^{3}$ & $3 \times 10^{2}$ \\
\hline $\begin{array}{l}{\left[\mathrm{O}_{3}\right]_{\mathrm{R}}} \\
{ }^{(4)}\left(\mathrm{mgO}_{3} / \mathrm{L}\right)\end{array}$ & 0 & & & & & & & \\
\hline $\begin{array}{l}{\left[\mathrm{O}_{3}\right]_{O F F-G A S}{ }^{(5)}} \\
\left(\mathrm{mgO}_{3} / \mathrm{L}\right)\end{array}$ & 0 , & & & & & & & \\
\hline $\mathrm{C}^{(6)}\left(\mathrm{mgO}_{3} / \mathrm{L}\right)$ & 5 , & & & & & & & \\
\hline
\end{tabular}


Tabela 5.24: Características físico-químicas e microbiológicas do esgoto no experimento I.

Experimento I $(5,6 ; 10)^{(1)}$

Variáveis

$\begin{array}{lcccc}\mathrm{EB}^{(2)} & \mathrm{EO}^{(3)} & \mathrm{EUV}_{1} & \mathrm{EUV}_{2} & \mathrm{EUV}_{3} \\ {\left[1 \mathrm{Wh} / \mathrm{m}^{3}\right]} & {\left[5 \mathrm{Wh} / \mathrm{m}^{3}\right]} & {\left[10 \mathrm{Wh} / \mathrm{m}^{3}\right]}\end{array}$

\begin{tabular}{lccccc}
\hline $\mathrm{T}\left({ }^{\circ} \mathrm{C}\right)$ & 20 & 20 & & & \\
$\mathrm{pH}$ & 7,1 & 6,2 & & \\
Alcalinidade Total $\left(\mathrm{mgCaCO}_{3} / \mathrm{L}\right)$ & 88 & 101 & & \\
$\mathrm{ST}(\mathrm{mg} / \mathrm{L})$ & 359 & 281 & & & \\
$\mathrm{SST}(\mathrm{mg} / \mathrm{L})$ & 60 & 34 & & & \\
$\mathrm{DQO}(\mathrm{mg} / \mathrm{L})$ & 322 & 280 & & & \\
E. coli $(\mathrm{UFC} / 100 \mathrm{~mL})$ & $2 \times 10^{6}$ & $5 \times 10^{5}$ & $1,3 \times 10^{3}$ & $<1$ & $<1$ \\
Coliformes totais $(\mathrm{UFC} / 100 \mathrm{~mL})$ & $4,3 \times 10^{7}$ & $2 \times 10^{6}$ & $3,1 \times 10^{4}$ & $5,3 \times 10^{3}$ & $1,4 \times 10^{3}$ \\
C. perfringens $(\mathrm{NMP} / 100 \mathrm{~mL})$ & $8 \times 10^{3}$ & $2,8 \times 10^{4}$ & $2,2 \times 10^{3}$ & $2,3 \times 10^{2}$ & $2,3 \times 10^{2}$ \\
{$\left[\mathrm{O}_{3}\right]_{\mathrm{R}}(4)\left(\mathrm{mgO}_{3} / \mathrm{L}\right)$} & \multicolumn{2}{c}{0,22} & & & \\
{$\left[\mathrm{O}_{3}\right]_{\text {OFF-GAS }}(5)\left(\mathrm{mgO}_{3} / \mathrm{L}\right)$} & \multicolumn{2}{c}{0,01} & & & \\
$\mathrm{C}^{(6)}\left(\mathrm{mgO}_{3} / \mathrm{L}\right)$ & 5,37 & & & \\
\hline
\end{tabular}

Notas: (1) concentração de ozônio aplicada (mg/L), tempo de contato (min); (2) efluente UASB bruto; (3) efluente ozonizado; (4) concentração de ozônio residual; (5) concentração de ozônio no off-gas; (6) concentração de ozônio consumido.

Tabela 5.25: Características físico-químicas e microbiológicas do esgoto no experimento II. Experimento II $(5,6 ; 20)^{(1)}$

Variáveis

$$
\begin{array}{lcccc}
\mathrm{EB}^{(2)} & \mathrm{EO}^{(3)} & \mathrm{EUV}_{1} & \mathrm{EUV}_{2} & \mathrm{EUV}_{3} \\
& {\left[1 \mathrm{Wh} / \mathrm{m}^{3}\right]} & {\left[3 \mathrm{Wh} / \mathrm{m}^{3}\right]} & {\left[5 \mathrm{Wh} / \mathrm{m}^{3}\right]}
\end{array}
$$

\begin{tabular}{lccccc}
\hline $\mathrm{T}\left({ }^{\circ} \mathrm{C}\right)$ & 20 & 20 & & & \\
$\mathrm{pH}$ & 6,8 & 7,2 & & & \\
Alcalinidade Total $\left(\mathrm{mgCaCO}_{3} / \mathrm{L}\right)$ & 179 & 201 & & & \\
$\mathrm{ST}(\mathrm{mg} / \mathrm{L})$ & 453 & 423 & & & \\
$\mathrm{SST}(\mathrm{mg} / \mathrm{L})$ & 150 & 104 & & & \\
$\mathrm{DQO}(\mathrm{mg} / \mathrm{L})$ & 549 & 494 & & & \\
E. coli $(\mathrm{UFC} / 100 \mathrm{~mL})$ & $1 \times 10^{6}$ & $5,9 \times 10^{5}$ & $3,5 \times 10^{3}$ & $6 \times 10^{2}$ & $4 \times 10^{2}$ \\
Coliformes totais $(\mathrm{UFC} / 100 \mathrm{~mL})$ & $2,1 \times 10^{7}$ & $3,7 \times 10^{6}$ & $9,2 \times 10^{4}$ & $2,1 \times 10^{3}$ & $1,7 \times 10^{3}$ \\
C. perfringens $(\mathrm{NMP} / 100 \mathrm{~mL})$ & $3 \times 10^{4}$ & $1,7 \times 10^{4}$ & $2,4 \times 10^{4}$ & $5 \times 10^{2}$ & $5 \times 10^{2}$ \\
{$\left[\mathrm{O}_{3}\right]_{\mathrm{R}}{ }^{(4)}\left(\mathrm{mgO}_{3} / \mathrm{L}\right)$} & \multicolumn{2}{c}{0,52} & & & \\
{$\left[\mathrm{O}_{3}\right]_{\text {OFF-GAS }}(5)\left(\mathrm{mgO}_{3} / \mathrm{L}\right)$} & \multicolumn{2}{c}{0,05} & & \\
$\mathrm{C}^{(6)}\left(\mathrm{mgO}_{3} / \mathrm{L}\right)$ & 5,03 & & \\
\hline
\end{tabular}

Notas: (1) concentração de ozônio aplicada (mg/L), tempo de contato (min); (2) efluente UASB bruto; (3) efluente ozonizado; (4) concentração de ozônio residual; (5) concentração de ozônio no off-gas; (6) concentração de ozônio consumido. 
Tabela 5.26: Características físico-químicas e microbiológicas do esgoto no experimento III-A.

Experimento III-A $(5,6 ; 30)^{(1)}$

Variáveis

$$
\begin{array}{lcccc}
\mathrm{EB}^{(2)} & \mathrm{EO}^{(3)} & \mathrm{EUV}_{1} & \mathrm{EUV}_{2} & \mathrm{EUV}_{3} \\
{\left[1 \mathrm{Wh} / \mathrm{m}^{3}\right]} & {\left[3 \mathrm{Wh} / \mathrm{m}^{3}\right]} & {\left[5 \mathrm{Wh} / \mathrm{m}^{3}\right]}
\end{array}
$$

\begin{tabular}{lccccc}
\hline $\mathrm{T}\left({ }^{\circ} \mathrm{C}\right)$ & 21 & 21 & & & \\
$\mathrm{pH}$ & 6,64 & 7,06 & & & \\
Alcalinidade Total $\left(\mathrm{mgCaCO}_{3} / \mathrm{L}\right)$ & 157 & 164 & & & \\
$\mathrm{ST}(\mathrm{mg} / \mathrm{L})$ & 463 & 400 & & & \\
$\mathrm{SST}(\mathrm{mg} / \mathrm{L})$ & 195 & 100 & & & \\
$\mathrm{DQO}(\mathrm{mg} / \mathrm{L})$ & 640 & 501 & & & \\
E. coli $(\mathrm{UFC} / 100 \mathrm{~mL})$ & $3 \times 10^{6}$ & $9 \times 10^{4}$ & $2,9 \times 10^{3}$ & $4 \times 10^{2}$ & $3 \times 10^{2}$ \\
Coliformes totais $(\mathrm{UFC} / 100 \mathrm{~mL})$ & $5,7 \times 10^{7}$ & $4,5 \times 10^{6}$ & $1 \times 10^{5}$ & $1,2 \times 10^{3}$ & $8 \times 10^{2}$ \\
C. perfringens $(\mathrm{NMP} / 100 \mathrm{~mL})$ & $5 \times 10^{4}$ & $1,7 \times 10^{4}$ & $3 \times 10^{3}$ & $8 \times 10^{2}$ & $2,3 \times 10^{2}$ \\
{$\left[\mathrm{O}_{3}\right]_{\mathrm{R}}{ }^{(4)}\left(\mathrm{mgO}_{3} / \mathrm{L}\right)$} & \multicolumn{2}{c}{0,59} & & & \\
{$\left[\mathrm{O}_{3}\right]_{\text {OFF-GAS }}(5)\left(\mathrm{mgO}_{3} / \mathrm{L}\right)$} & \multicolumn{2}{c}{0,04} & & \\
$\mathrm{C}^{(6)}\left(\mathrm{mgO}_{3} / \mathrm{L}\right)$ & 4,97 & & \\
\hline
\end{tabular}

Notas: (1) concentração de ozônio aplicada (mg/L), tempo de contato (min); (2) efluente UASB bruto; (3) efluente ozonizado; (4) concentração de ozônio residual; (5) concentração de ozônio no off-gas; (6) concentração de ozônio consumido.

Tabela 5.27: Características físico-químicas e microbiológicas do esgoto no experimento III-B.

Experimento III-B $(5,6 ; 30)^{(1)}$

Variáveis

$\begin{array}{llccc}\mathrm{EB}^{(2)} & \mathrm{EO}^{(3)} & \mathrm{EUV}_{1} & \mathrm{EUV}_{2} & \mathrm{EUV}_{3} \\ & & {\left[0,5 \mathrm{Wh} / \mathrm{m}^{3}\right]} & {\left[1 \mathrm{Wh} / \mathrm{m}^{3}\right]} & {\left[1,5 \mathrm{Wh} / \mathrm{m}^{3}\right]}\end{array}$

\begin{tabular}{lccccc}
\hline $\mathrm{T}\left({ }^{\circ} \mathrm{C}\right)$ & 21 & 21 & & & \\
$\mathrm{pH}$ & 6,51 & 7,02 & & & \\
Alcalinidade Total $\left(\mathrm{mgCaCO}_{3} / \mathrm{L}\right)$ & 70 & 62 & & \\
$\mathrm{ST}(\mathrm{mg} / \mathrm{L})$ & 245 & 218 & & & \\
$\mathrm{SST}(\mathrm{mg} / \mathrm{L})$ & 106 & 42 & & & \\
$\mathrm{DQO}(\mathrm{mg} / \mathrm{L})$ & 287 & 181 & & & \\
E. coli $(\mathrm{UFC} / 100 \mathrm{~mL})$ & $2 \times 10^{6}$ & $5 \times 10^{3}$ & $9 \times 10^{2}$ & $9 \times 10^{2}$ & $1 \times 10^{2}$ \\
Coliformes totais $(\mathrm{UFC} / 100 \mathrm{~mL})$ & $1 \times 10^{8}$ & $7,6 \times 10^{5}$ & $8 \times 10^{3}$ & $2 \times 10^{3}$ & $1,2 \times 10^{3}$ \\
C. perfringens $(\mathrm{NMP} / 100 \mathrm{~mL})$ & $3 \times 10^{4}$ & $5 \times 10^{3}$ & $2,4 \times 10^{3}$ & $2,4 \times 10^{3}$ & $2,7 \times 10^{2}$ \\
{$\left[\mathrm{O}_{3}\right]_{\mathrm{R}}{ }^{(4)}\left(\mathrm{mgO}_{3} / \mathrm{L}\right)$} & \multicolumn{2}{c}{0,21} & & & \\
{$\left[\mathrm{O}_{3}\right]_{\text {OFF-GAS }}{ }^{(5)}\left(\mathrm{mgO}_{3} / \mathrm{L}\right)$} & \multicolumn{2}{c}{0,11} & & & \\
$\mathrm{C}^{(6)}\left(\mathrm{mgO}_{3} / \mathrm{L}\right)$ & 5,28 & & & \\
\hline
\end{tabular}

Notas: (1) concentração de ozônio aplicada ( $\mathrm{mg} / \mathrm{L}$ ), tempo de contato (min); (2) efluente UASB bruto; (3) efluente ozonizado; (4) concentração de ozônio residual; (5) concentração de ozônio no off-gas; (6) concentração de ozônio consumido. 
Tabela 5.28: Características físico-químicas e microbiológicas do esgoto no experimento IV.

Experimento IV $(10,5 ; 10)^{(1)}$

Variáveis

$$
\begin{array}{lcccc}
\mathrm{EB}^{(2)} & \mathrm{EO}^{(3)} & \mathrm{EUV}_{1} & \mathrm{EUV}_{2} & \mathrm{EUV}_{3} \\
& {\left[1 \mathrm{Wh} / \mathrm{m}^{3}\right]} & {\left[5 \mathrm{Wh} / \mathrm{m}^{3}\right]} & {\left[10 \mathrm{Wh} / \mathrm{m}^{3}\right]}
\end{array}
$$

\begin{tabular}{lll}
\hline $\mathrm{T}\left({ }^{\circ} \mathrm{C}\right)$ & 21,8 & 21,8 \\
$\mathrm{pH}$ & 6,47 & 6,82
\end{tabular}

Alcalinidade Total $\left(\mathrm{mgCaCO}_{3} / \mathrm{L}\right)$

$\mathrm{ST}(\mathrm{mg} / \mathrm{L}) \quad 272 \quad 229$

SST (mg/L) $134 \quad 63$

DQO (mg/L) $341 \quad 245$

E. coli $(\mathrm{UFC} / 100 \mathrm{~mL}) \quad 2 \times 10^{6} \quad 2 \times 10^{3} \quad 1 \times 10^{1} \quad<1<1$

$\begin{array}{llllll}\text { Coliformes totais (UFC/100mL) } & 8,4 \times 10^{7} & 4,7 \times 10^{5} & 2 \times 10^{3} & 1 \times 10^{2} & 2 \times 10^{2}\end{array}$

C. perfringens $(\mathrm{NMP} / 100 \mathrm{~mL}) \quad 7 \times 10^{3} \quad 1,3 \times 10^{4} \quad 7 \times 10^{2} \quad<1<1$

$\left[\mathrm{O}_{3}\right]_{\mathrm{R}}{ }^{(4)}\left(\mathrm{mgO}_{3} / \mathrm{L}\right)$

$\left[\mathrm{O}_{3}\right]_{\text {OFF-GAS }}{ }^{(5)}\left(\mathrm{mgO}_{3} / \mathrm{L}\right)$

$\mathrm{C}^{(6)}\left(\mathrm{mgO}_{3} / \mathrm{L}\right)$

Notas: (1) concentração de ozônio aplicada (mg/L), tempo de contato (min); (2) efluente UASB bruto; (3) efluente ozonizado; (4) concentração de ozônio residual; (5) concentração de ozônio no off-gas; (6) concentração de ozônio consumido.

Tabela 5.29: Características físico-químicas e microbiológicas do esgoto no experimento V-A.

\begin{tabular}{|c|c|c|c|c|c|}
\hline \multirow[b]{2}{*}{ Variáveis } & \multicolumn{5}{|c|}{ Experimento V-A $(11,1 ; 20)^{(1)}$} \\
\hline & $\mathrm{EB}^{(2)}$ & $\mathrm{EO}^{(3)}$ & $\begin{array}{c}\mathrm{EUV}_{1} \\
{\left[1 \mathrm{Wh} / \mathrm{m}^{3}\right]}\end{array}$ & $\begin{array}{c}\mathrm{EUV}_{2} \\
{\left[3 \mathrm{Wh} / \mathrm{m}^{3}\right]}\end{array}$ & $\begin{array}{c}\mathrm{EUV}_{3} \\
{\left[5 \mathrm{Wh} / \mathrm{m}^{3}\right]}\end{array}$ \\
\hline $\mathrm{T}\left({ }^{\circ} \mathrm{C}\right)$ & 20,4 & 20,4 & & & \\
\hline $\mathrm{pH}$ & 6,84 & 7,64 & & & \\
\hline Alcalinidade Total $\left(\mathrm{mgCaCO}_{3} / \mathrm{L}\right)$ & 181 & 180 & & & \\
\hline $\mathrm{ST}(\mathrm{mg} / \mathrm{L})$ & 319 & 276 & & & \\
\hline $\operatorname{SST}(\mathrm{mg} / \mathrm{L})$ & 104 & 33 & & & \\
\hline DQO (mg/L) & 429 & 269 & & & \\
\hline E. coli $(\mathrm{UFC} / 100 \mathrm{~mL})$ & $1 \times 10^{6}$ & $5,3 \times 10^{5}$ & $7 \times 10^{3}$ & $2 \times 10^{2}$ & $5 \times 10^{1}$ \\
\hline Coliformes totais $(\mathrm{UFC} / 100 \mathrm{~mL})$ & $5 \times 10^{6}$ & $2,8 \times 10^{6}$ & $4,9 \times 10^{4}$ & $1,6 \times 10^{3}$ & $2,9 \times 10^{2}$ \\
\hline C. perfringens (NMP/100mL) & $7 \times 10^{3}$ & $5 \times 10^{3}$ & $3 \times 10^{3}$ & $3 \times 10^{2}$ & $<1$ \\
\hline$\left[\mathrm{O}_{3}\right]_{\mathrm{R}}^{(4)}\left(\mathrm{mgO}_{3} / \mathrm{L}\right)$ & \multicolumn{2}{|c|}{0,33} & & & \\
\hline$\left[\mathrm{O}_{3}\right]_{O F F-G A S}{ }^{(5)}\left(\mathrm{mgO}_{3} / \mathrm{L}\right)$ & \multicolumn{2}{|c|}{0,00} & & & \\
\hline $\mathrm{C}^{(6)}\left(\mathrm{mgO}_{3} / \mathrm{L}\right)$ & \multicolumn{2}{|c|}{10,77} & & & \\
\hline
\end{tabular}

Notas: (1) concentração de ozônio aplicada (mg/L), tempo de contato (min); (2) efluente UASB bruto; (3) efluente ozonizado; (4) concentração de ozônio residual; (5) concentração de ozônio no off-gas; (6) concentração de ozônio consumido. 
Tabela 5.30: Características físico-químicas e microbiológicas do esgoto no experimento V-B.

Experimento $\mathrm{V}-\mathrm{B}(11,1 ; 20)^{(1)}$

Variáveis

$\begin{array}{lcccc}\mathrm{EB}^{(2)} & \mathrm{EO}^{(3)} & \mathrm{EUV}_{1} & \mathrm{EUV}_{2} & \mathrm{EUV}_{3} \\ & & {\left[1 \mathrm{Wh} / \mathrm{m}^{3}\right]} & {\left[2 \mathrm{Wh} / \mathrm{m}^{3}\right]} & {\left[3 \mathrm{Wh} / \mathrm{m}^{3}\right]}\end{array}$

\begin{tabular}{lll}
\hline $\mathrm{T}\left({ }^{\circ} \mathrm{C}\right)$ & 19,7 & 19,7 \\
$\mathrm{pH}$ & 6,64 & 7,64
\end{tabular}

Alcalinidade Total $\left(\mathrm{mgCaCO}_{3} / \mathrm{L}\right) \quad 112 \quad 125$

$\mathrm{ST}(\mathrm{mg} / \mathrm{L}) \quad 226 \quad 172$

$\mathrm{SST}(\mathrm{mg} / \mathrm{L}) \quad 48 \quad 14$

DQO $(\mathrm{mg} / \mathrm{L}) \quad 270 \quad 202$

E. coli (UFC/100mL) $\quad 4 \times 10^{5} \quad 1,3 \times 10^{3} \quad 1 \times 10^{3} \quad 1 \times 10^{3} \quad 3 \times 10^{2}$

Coliformes totais (UFC/100mL) $\quad 1,5 \times 10^{7} \quad 5,1 \times 10^{4} \quad 4 \times 10^{3} \quad 2,1 \times 10^{3} \quad 9,5 \times 10^{2}$

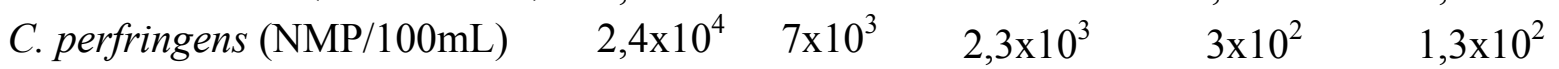

$\left[\mathrm{O}_{3}\right]_{\mathrm{R}}{ }^{(4)}\left(\mathrm{mgO}_{3} / \mathrm{L}\right)$

$\left[\mathrm{O}_{3}\right]_{\text {OFF-GAS }}{ }^{(5)}\left(\mathrm{mgO}_{3} / \mathrm{L}\right) \quad 0,90$

$\mathrm{C}^{(6)}\left(\mathrm{mgO}_{3} / \mathrm{L}\right)$

Notas: (1) concentração de ozônio aplicada (mg/L), tempo de contato (min); (2) efluente UASB bruto; (3) efluente ozonizado; (4) concentração de ozônio residual; (5) concentração de ozônio no off-gas; (6) concentração de ozônio consumido.

Tabela 5.31: Características físico-químicas e microbiológicas do esgoto no experimento VI.

Experimento VI $(11,1 ; 30)^{(1)}$

\begin{tabular}{|c|c|c|c|c|c|}
\hline Variáveis & $\mathrm{EB}^{(2)}$ & $\mathrm{EO}^{(3)}$ & $\begin{array}{c}\mathrm{EUV}_{1} \\
{\left[1 \mathrm{Wh} / \mathrm{m}^{3}\right]}\end{array}$ & $\begin{array}{c}\mathrm{EUV}_{2} \\
{\left[3 \mathrm{Wh} / \mathrm{m}^{3}\right]}\end{array}$ & $\begin{array}{c}\mathrm{EUV}_{3} \\
{\left[5 \mathrm{Wh} / \mathrm{m}^{3}\right]}\end{array}$ \\
\hline $\mathrm{T}\left({ }^{\circ} \mathrm{C}\right)$ & 19,5 & 19,5 & & & \\
\hline $\mathrm{pH}$ & 6,68 & 7,61 & & & \\
\hline Alcalinidade Total $\left(\mathrm{mgCaCO}_{3} / \mathrm{L}\right)$ & 237 & 251 & & & \\
\hline $\mathrm{ST}(\mathrm{mg} / \mathrm{L})$ & 551 & 416 & & & \\
\hline SST (mg/L) & 245 & 137 & & & \\
\hline DQO $(\mathrm{mg} / \mathrm{L})$ & 794 & 415 & & & \\
\hline E. coli $(\mathrm{UFC} / 100 \mathrm{~mL})$ & $7 \times 10^{5}$ & $6,2 \times 10^{5}$ & $9 \times 10^{3}$ & $9 \times 10^{1}$ & $1 \times 10^{1}$ \\
\hline Coliformes totais (UFC/100mL) & $5,2 \times 10^{6}$ & $3,4 \times 10^{6}$ & $4,9 \times 10^{4}$ & $2,1 \times 10^{2}$ & $2 \times 10^{2}$ \\
\hline C. perfringens (NMP/100mL) & $1,7 \times 10^{4}$ & $3 \times 10^{4}$ & $8 \times 10^{3}$ & $2,3 \times 10^{2}$ & $4 \times 10^{1}$ \\
\hline$\left[\mathrm{O}_{3}\right]_{\mathrm{R}}{ }^{(4)}\left(\mathrm{mgO}_{3} / \mathrm{L}\right)$ & \multicolumn{2}{|c|}{0,68} & & & \\
\hline$\left[\mathrm{O}_{3}\right]_{O F F-G A S}{ }^{(5)}\left(\mathrm{mgO}_{3} / \mathrm{L}\right)$ & \multicolumn{2}{|c|}{0,00} & & & \\
\hline $\mathrm{C}^{(6)}\left(\mathrm{mgO}_{3} / \mathrm{L}\right)$ & \multicolumn{2}{|c|}{10,42} & & & \\
\hline
\end{tabular}

Notas: (1) concentração de ozônio aplicada $(\mathrm{mg} / \mathrm{L})$, tempo de contato (min); (2) efluente UASB bruto; (3) efluente ozonizado; (4) concentração de ozônio residual; (5) concentração de ozônio no off-gas; (6) concentração de ozônio consumido. 
Tabela 5.32: Características físico-químicas e microbiológicas do esgoto no experimento VII. Experimento VII $(15,8 ; 10)^{(1)}$

Variáveis

$\begin{array}{lcccc}\mathrm{EB}^{(2)} & \mathrm{EO}^{(3)} & \mathrm{EUV}_{1} & \mathrm{EUV}_{2} & \mathrm{EUV}_{3} \\ {\left[1 \mathrm{Wh} / \mathrm{m}^{3}\right]} & {\left[3 \mathrm{Wh} / \mathrm{m}^{3}\right]} & {\left[5 \mathrm{Wh} / \mathrm{m}^{3}\right]}\end{array}$

\begin{tabular}{lccccc}
\hline $\mathrm{T}\left({ }^{\circ} \mathrm{C}\right)$ & 20,2 & 20,2 & & & \\
$\mathrm{pH}$ & 6,89 & 7,56 & & & \\
Alcalinidade Total $\left(\mathrm{mgCaCO}_{3} / \mathrm{L}\right)$ & 205 & 200 & & & \\
$\mathrm{ST}(\mathrm{mg} / \mathrm{L})$ & 743 & 485 & & & \\
$\mathrm{SST}(\mathrm{mg} / \mathrm{L})$ & 476 & 191 & & & \\
$\mathrm{DQO}(\mathrm{mg} / \mathrm{L})$ & 1011 & 534 & & & \\
E. coli $(\mathrm{UFC} / 100 \mathrm{~mL})$ & $1,1 \times 10^{6}$ & $8 \times 10^{5}$ & $3 \times 10^{3}$ & $3 \times 10^{2}$ & $1 \times 10^{2}$ \\
Coliformes totais $(\mathrm{UFC} / 100 \mathrm{~mL})$ & $2,6 \times 10^{7}$ & $1,1 \times 10^{7}$ & $8,6 \times 10^{4}$ & $2,3 \times 10^{3}$ & $7 \times 10^{2}$ \\
C. perfringens $(\mathrm{NMP} / 100 \mathrm{~mL})$ & $5 \times 10^{4}$ & $1,6 \times 10^{5}$ & $3 \times 10^{4}$ & $1,7 \times 10^{2}$ & $1,7 \times 10^{2}$ \\
{$\left[\mathrm{O}_{3}\right]_{\mathrm{R}}{ }^{(4)}\left(\mathrm{mgO}_{3} / \mathrm{L}\right)$} & \multicolumn{2}{c}{1,39} & & & \\
{$\left[\mathrm{O}_{3}\right]_{\text {OFF-GAS }}{ }^{(5)}\left(\mathrm{mgO}_{3} / \mathrm{L}\right)$} & 0,04 & & & \\
$\mathrm{C}^{(6)}\left(\mathrm{mgO}_{3} / \mathrm{L}\right)$ & 14,37 & & & \\
\hline
\end{tabular}

Notas: (1) concentração de ozônio aplicada (mg/L), tempo de contato (min); (2) efluente UASB bruto; (3) efluente ozonizado; (4) concentração de ozônio residual; (5) concentração de ozônio no off-gas; (6) concentração de ozônio consumido.

Tabela 5.33: Características físico-químicas e microbiológicas do esgoto no experimento VIII.

$$
\text { Experimento VIII }(16,7 ; 20)^{(1)}
$$

Variáveis

$$
\begin{array}{lcccc}
\mathrm{EB}^{(2)} & \mathrm{EO}^{(3)} & \mathrm{EUV}_{1} & \mathrm{EUV}_{2} & \mathrm{EUV}_{3} \\
& {\left[1 \mathrm{Wh} / \mathrm{m}^{3}\right]} & {\left[3 \mathrm{Wh} / \mathrm{m}^{3}\right]} & {\left[5 \mathrm{Wh} / \mathrm{m}^{3}\right]}
\end{array}
$$

\begin{tabular}{lccccc}
\hline $\mathrm{T}\left({ }^{\circ} \mathrm{C}\right)$ & 20,8 & 20,8 & & & \\
$\mathrm{pH}$ & 7 & 7,83 & & & \\
Alcalinidade Total $\left(\mathrm{mgCaCO}_{3} / \mathrm{L}\right)$ & 167 & 169 & & & \\
$\mathrm{ST}(\mathrm{mg} / \mathrm{L})$ & 601 & 385 & & & \\
$\mathrm{SST}(\mathrm{mg} / \mathrm{L})$ & 190 & 55 & & & \\
$\mathrm{DQO}(\mathrm{mg} / \mathrm{L})$ & 574 & 222 & & & \\
E. coli $(\mathrm{UFC} / 100 \mathrm{~mL})$ & $1 \times 10^{6}$ & $1 \times 10^{4}$ & $7 \times 10^{2}$ & $1,4 \times 10^{2}$ & $1,5 \times 10^{2}$ \\
Coliformes totais $(\mathrm{UFC} / 100 \mathrm{~mL})$ & $3,7 \times 10^{7}$ & $4 \times 10^{5}$ & $1,4 \times 10^{4}$ & $1,3 \times 10^{3}$ & $6,2 \times 10^{2}$ \\
C. perfringens $(\mathrm{NMP} / 100 \mathrm{~mL})$ & $1,6 \times 10^{5}$ & $2,8 \times 10^{4}$ & $5 \times 10^{3}$ & $1,1 \times 10^{3}$ & $1,7 \times 10^{2}$ \\
{$\left[\mathrm{O}_{3}\right]_{\mathrm{R}}(4)\left(\mathrm{mgO}_{3} / \mathrm{L}\right)$} & 0,62 & & & \\
$\left.\left[\mathrm{O}_{3}\right]_{\text {OFF-GAS }}{ }^{5}\right)\left(\mathrm{mgO}_{3} / \mathrm{L}\right)$ & 0,62 & & & \\
$\mathrm{C}^{(6)}\left(\mathrm{mgO}_{3} / \mathrm{L}\right)$ & \multicolumn{2}{c}{15,46} & & & \\
\hline
\end{tabular}

Notas: (1) concentração de ozônio aplicada (mg/L), tempo de contato (min); (2) efluente UASB bruto; (3) efluente ozonizado; (4) concentração de ozônio residual; (5) concentração de ozônio no off-gas; (6) concentração de ozônio consumido. 
Tabela 5.34: Características físico-químicas e microbiológicas do esgoto no experimento IX.

Experimento IX $(16,7 ; 30)^{(1)}$

Variáveis

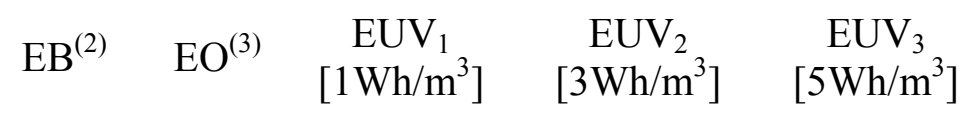

\begin{tabular}{lccccc}
\hline $\mathrm{T}\left({ }^{\circ} \mathrm{C}\right)$ & 19 & 19 & & & \\
$\mathrm{pH}$ & 7,06 & 7,61 & & & \\
Alcalinidade Total $\left(\mathrm{mgCaCO}_{3} / \mathrm{L}\right)$ & 136 & 136 & & \\
$\mathrm{ST}(\mathrm{mg} / \mathrm{L})$ & 439 & 369 & & & \\
$\mathrm{SST}(\mathrm{mg} / \mathrm{L})$ & 205 & 109 & & & \\
$\mathrm{DQO}(\mathrm{mg} / \mathrm{L})$ & 484 & 325 & & & \\
E. coli $(\mathrm{UFC} / 100 \mathrm{~mL})$ & $3 \times 10^{6}$ & $8 \times 10^{3}$ & $5 \times 10^{2}$ & $1,6 \times 10^{2}$ & $3 \times 10^{2}$ \\
Coliformes totais $(\mathrm{UFC} / 100 \mathrm{~mL})$ & $5,6 \times 10^{7}$ & $1 \times 10^{6}$ & $5,4 \times 10^{3}$ & $8 \times 10^{2}$ & $6,6 \times 10^{2}$ \\
C. perfringens $(\mathrm{NMP} / 100 \mathrm{~mL})$ & $3 \times 10^{4}$ & $3 \times 10^{4}$ & $1,1 \times 10^{4}$ & $7 \times 10^{2}$ & $1,1 \times 10^{2}$ \\
{$\left[\mathrm{O}_{3}\right]_{\mathrm{R}}{ }^{(4)}\left(\mathrm{mgO}_{3} / \mathrm{L}\right)$} & 0,54 & & & \\
{$\left[\mathrm{O}_{3}\right]_{\mathrm{OFF}-\mathrm{GAS}}{ }^{(5)}\left(\mathrm{mgO}_{3} / \mathrm{L}\right)$} & 2,05 & & & \\
$\mathrm{C}^{(6)}\left(\mathrm{mgO}_{3} / \mathrm{L}\right)$ & 14,11 & & & \\
\hline
\end{tabular}

Notas: (1) concentração de ozônio aplicada (mg/L), tempo de contato (min); (2) efluente UASB bruto; (3) efluente ozonizado; (4) concentração de ozônio residual; (5) concentração de ozônio no off-gas; (6) concentração de ozônio consumido.

\subsection{1 pH}

Houve uma tendência de aumento do $\mathrm{pH}$ e da alcalinidade após a ozonização, como fica claramente ilustrado na Figura 5.20 para o pH, e nas TabelasTabela 5.23 a 5.34 para a alcalinidade. $\mathrm{O}$ aumento dos valores de $\mathrm{pH}$ pode ser devido ao stripping de gás $\mathrm{CO}_{2}$. A remoção deste gás pode promover a diminuição da concentração de $\mathrm{H}^{+}$como foi observado nos trabalhos de SOARES (2007) e COSTA (2003).

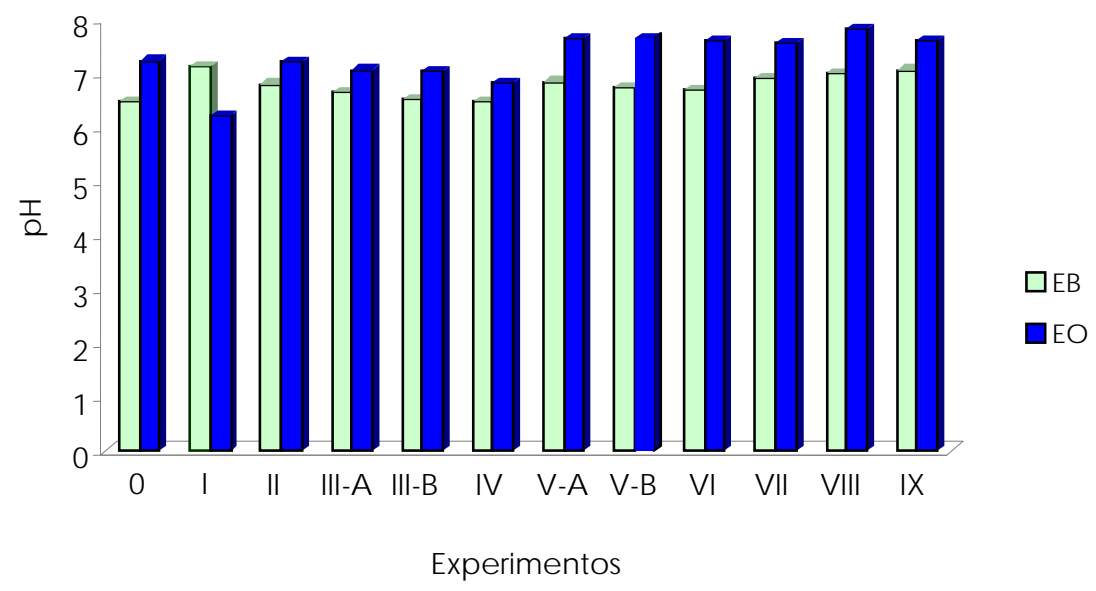

Figura 5.20: Variação do pH para os ensaios de ozonização. 
A média do $\mathrm{pH}$ para o efluente do reator UASB foi de 6,77 e para o ozonizado 7,39. Valores de variáveis estatísticas para os ensaios de ozonização para o pH estão descritos na Tabela 5.35 .

Tabela 5.35: Resumo estatístico dos valores de $\mathrm{pH}$ de todos os experimentos de desinfecção com ozônio.

\begin{tabular}{lrr}
\hline & \multicolumn{1}{c}{$E B$} & \multicolumn{1}{c}{$E O$} \\
\hline Média & 6,77 & 7,29 \\
Erro padrão & 0,064391 & 0,132501 \\
Mediana & 6,77 & 7,395 \\
Desvio padrão & 0,223056 & 0,458998 \\
Variância da & & \\
amostra & 0,049754 & 0,210679 \\
Curtose & $-1,15364$ & 1,275898 \\
Assimetria & 0,107925 & $-1,13947$ \\
Intervalo & 0,65 & 1,61 \\
Mínimo & 6,47 & 6,22 \\
Máximo & 7,12 & 7,83 \\
Soma & 81,23 & 87,44 \\
Contagem & 12 & 12 \\
\hline
\end{tabular}

\subsubsection{DQO}

A Figura 5.21 representa a variação da DQO do efluente bruto (EB) e do ozonizado (EO) em todos os experimentos e sua porcentagem de remoção.

É observado remoção de DQO após aplicação de ozônio de mais de $60 \%$. O aumento na porcentagem de remoção parece apresentar uma proporcionalidade como o aumento da dosagem de ozônio aplicada (Figura 5.21).

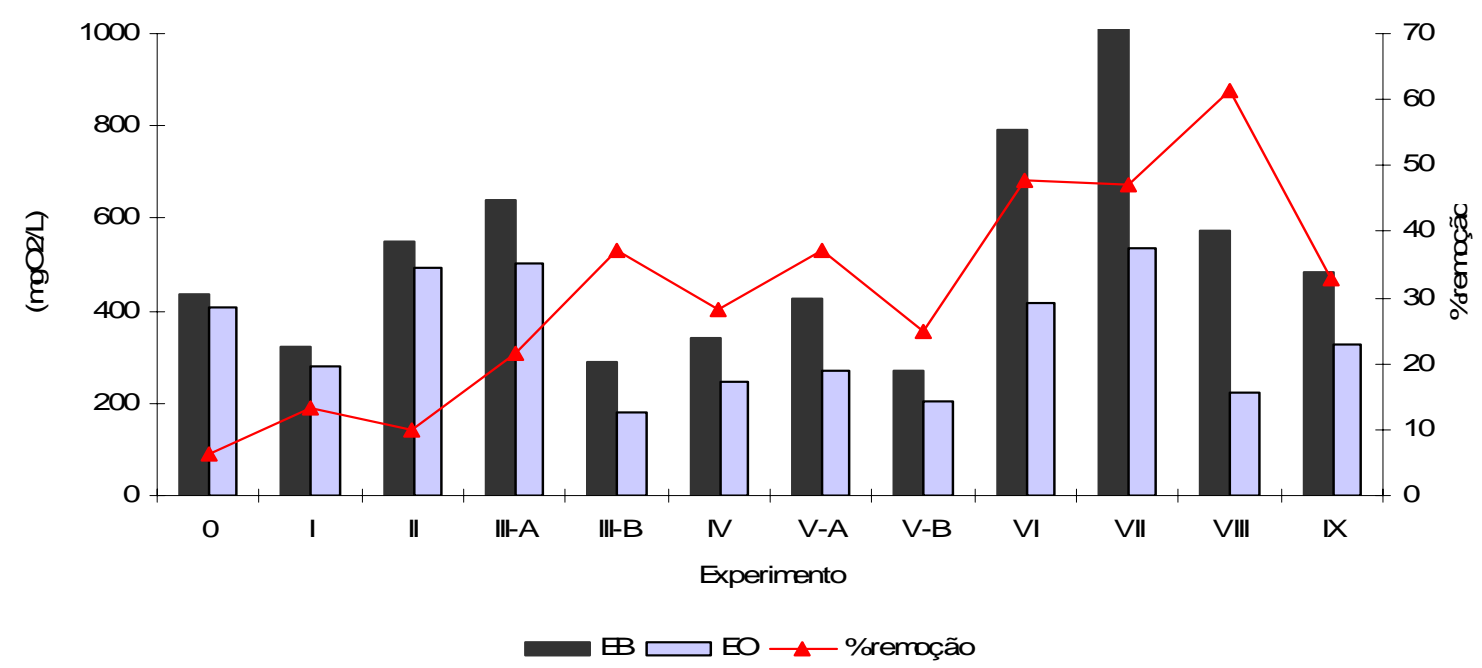

Figura 5.21: Variação da DQO nos ensaios de desinfecção com ozônio. 
Existe uma relação entre a massa de DQO removida e a massa de ozônio consumida como mostra a Figura 5.22. Desta maneira pode-se inferir que a oxidação da matéria orgânica pode ser promovida pelo ozônio. Esta dúvida sobre oxidação da matéria orgânica pode advir do fato de ocorrer remoção mecânica de partículas com a formação de espuma ao longo da ozonização.

A massa de DQO removida é obtida pelas equações (5.11) e (5.12).

$$
D Q O_{r}(m g)=\frac{E f(\%) * D Q O_{E B}(m g / L) * V(L)}{100}
$$

DQOr: massa de DQO removida;

Ef(100\%): eficiência de remoção;

$\mathrm{DQO}_{\mathrm{EB}}$ : DQO do efluente bruto;

$\mathrm{V}(\mathrm{L})$ : volume de esgoto desinfetado;

$$
E f(\%)=\frac{D Q O_{E B}-D Q O_{E O}}{D Q O_{E O}} * 100
$$

$\mathrm{DQO}_{\mathrm{EO}}$ : DQO do efluente ozonizado;

A massa de DQO removida (DQOr) calculada pela equação 5.11 e os valores de massa de ozônio consumido estão apresentados na Tabela 5.22.

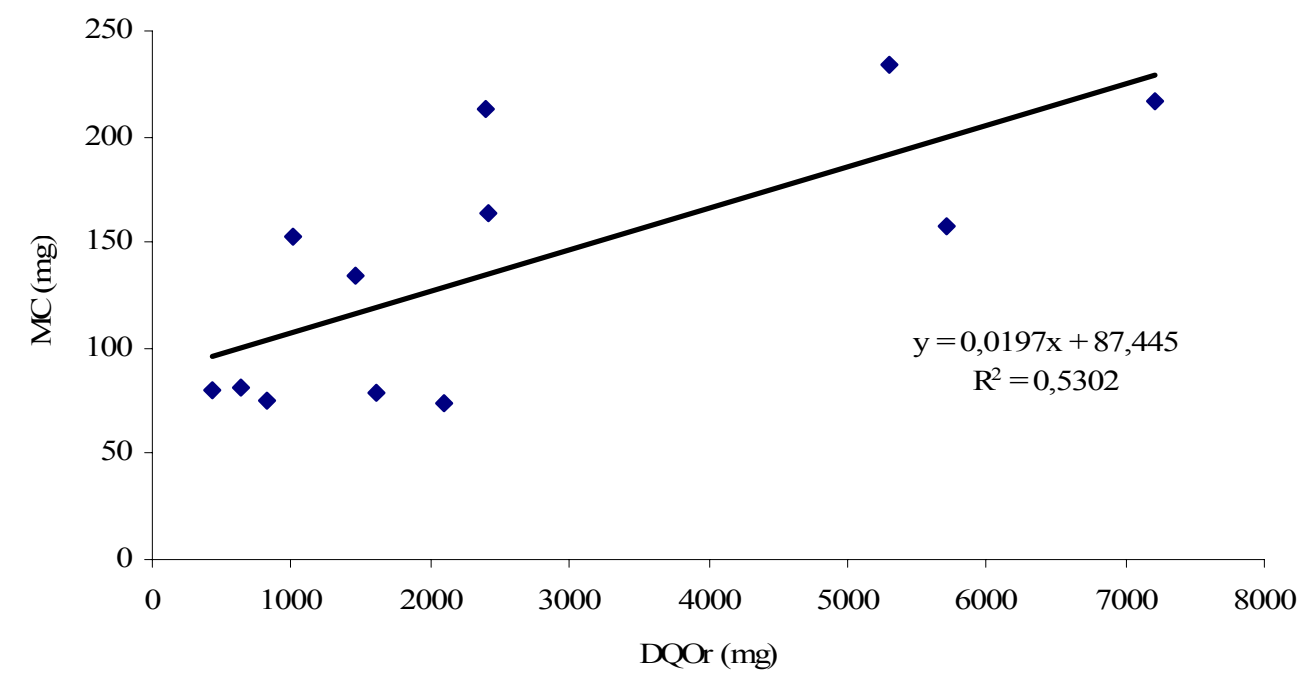

Figura 5.22: Relação entre a massa de DQO removida (DQOr) e a massa de ozônio consumido.

A DQO média do efluente do reator UASB para as amostras que antecederam a ozonização foi de $511 \mathrm{mgO}_{2} / \mathrm{L}$. Após a ozonização a DQO média reduziu-se para 340 $\mathrm{mgO}_{2} / \mathrm{L}$, como pode ser visto na Tabela 5.36. 
Tabela 5.36: Análise estatística do Efluente Bruto e do ozonizado para a DQO.

\begin{tabular}{lrr}
\hline & \multicolumn{1}{c}{$E B$} & \multicolumn{1}{c}{$E O$} \\
\hline Média & 511 & 340 \\
Erro padrão & 63,8383 & 36,2505 \\
Mediana & 459,8576 & 302,4782 \\
Desvio padrão & 221,1426 & 125,5755 \\
Variância da & & \\
amostra & 48904,06 & 15769,21 \\
Curtose & 1,052397 & $-1,48703$ \\
Assimetria & 1,127202 & 0,346656 \\
Intervalo & 741,1966 & 353,1479 \\
Mínimo & 269,9806 & 180,5637 \\
Máximo & 1011,177 & 533,7116 \\
Soma & 6136,138 & 4075,813 \\
Contagem & 12 & 12 \\
\hline
\end{tabular}

A DQO exerce demanda de ozônio devido à oxidação da matéria orgânica e inorgânica diminuindo a disponibilidade de ozônio para ação desinfetante (DIAS, 2001).

\subsubsection{Sólidos Totais}

Uma característica indesejável para a desinfecção é a elevada concentração de ST e SST. Os sólidos conferem proteção física contra a penetração do agente desinfetante e ainda competem com este na ação de oxidação, aumentando a demanda de desinfetante, podendo causar a necessidade de maiores dosagens de desinfetante tendo como consequência aumento de custos de operação.

A Figura 5.23 representa a variação dos sólidos totais antes e após a ozonização.

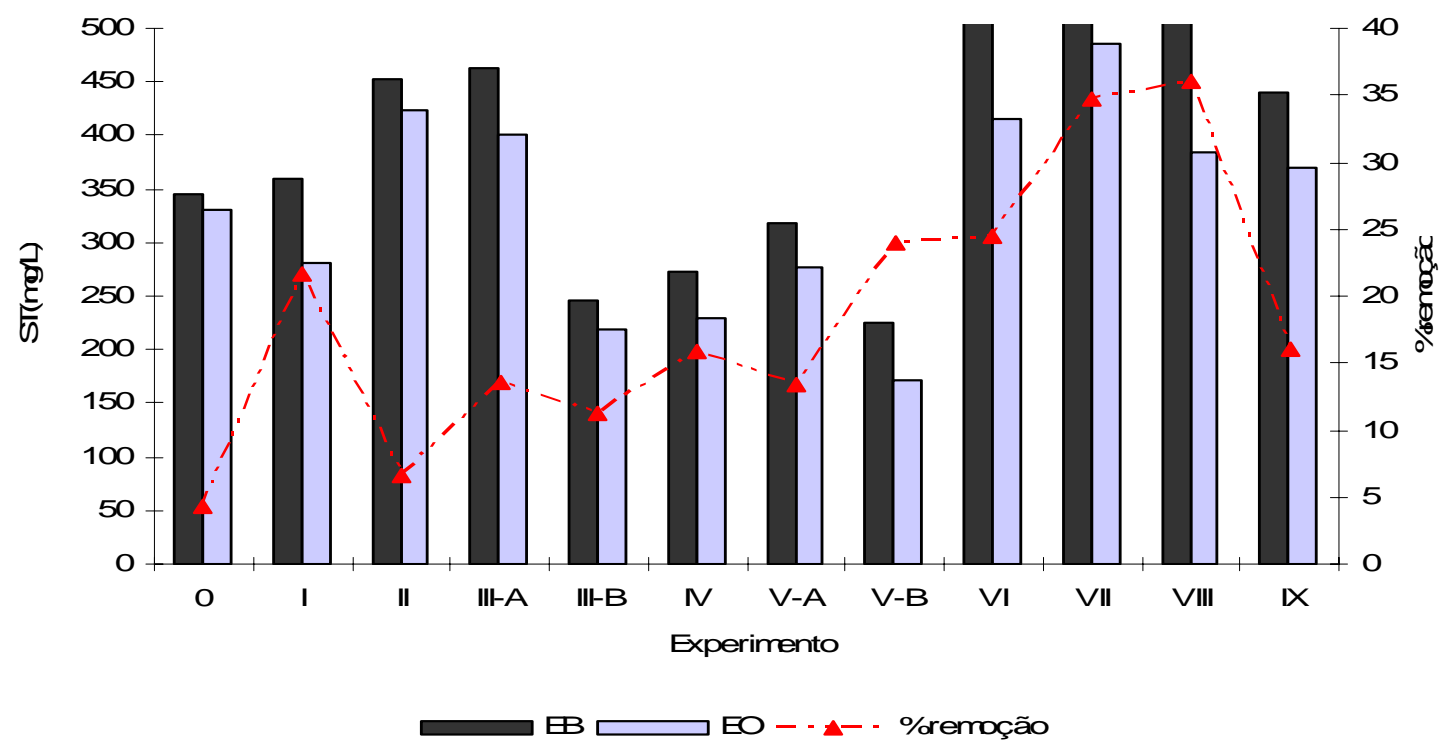

Figura 5.23: Variação dos Sólidos Totais nos ensaios de ozonização. 
De uma maneira geral ocorreu diminuição dos valores de sólidos totais após a ozonização, atingindo até 35 \% de remoção para maiores doses de ozônio. Esta remoção pode ser resultante da oxidação que o ozônio promove na matéria degradável, ou ainda pode ser pelo arraste mecânico através das bolhas de gás, na forma de espuma removida durante a ozonização.

Ao observar a Tabela 5.37 nota-se que a concentração média de sólidos totais decresce de 418 para 332 após a ozonização.

Tabela 5.37: Análise estatística do efluente bruto e do efluente ozonizado para ST.

\begin{tabular}{lrr}
\hline & \multicolumn{1}{c}{$E B$} & \multicolumn{1}{c}{$E O$} \\
\hline Média & 418 & 332 \\
Erro padrão & 44,99206 & 27,865342 \\
Mediana & 399,5 & 349,5 \\
Desvio padrão & 155,8571 & 96,528375 \\
Variância da & & \\
amostra & 24291,43 & 9317,7273 \\
Curtose & 0,104142 & $-1,023705$ \\
Assimetria & 0,751017 & $-0,190534$ \\
Intervalo & 518 & 313,5 \\
Mínimo & 225,5 & 171,5 \\
Máximo & 743,5 & 485 \\
Soma & 5016,5 & 3984 \\
Contagem & 12 & 12 \\
\hline
\end{tabular}

\subsubsection{Sólidos Suspensos Totais}

Altos valores de sólidos suspensos totais limitam a ação germicida dos desinfetantes, pois resulta em agregados partículas-microrganismo, que dificultam, ou mesmo impossibilitam, a ação dos agentes desinfetantes sobre os microrganismos (DIAS, 2001).

A Figura 5.24 representa a variação dos sólidos suspensos totais no efluente bruto e no efluente ozonizado. Assim como para os ST, ocorreu remoção de SST após a ozonização, possivelmente pelo mesmo fenômeno discutido para ST. 


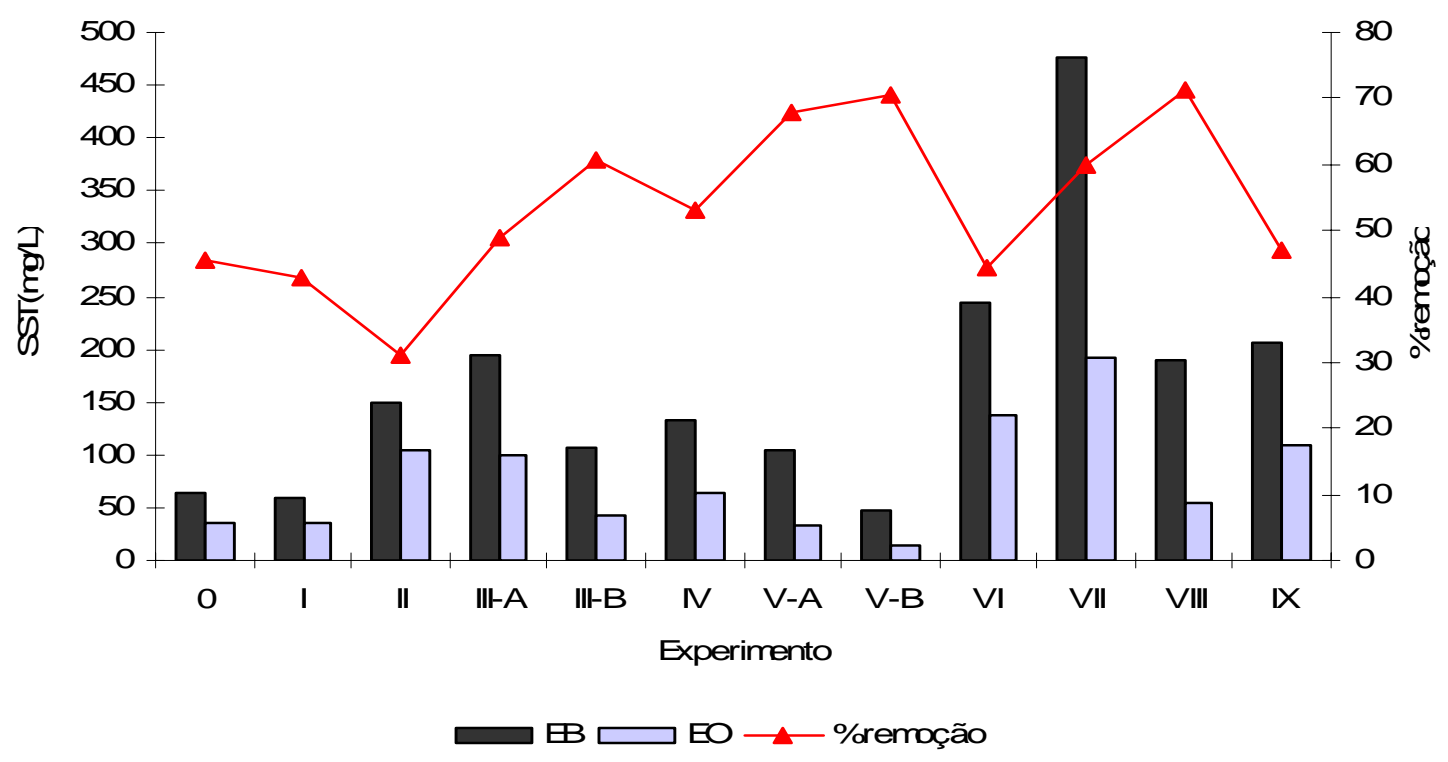

Figura 5.24: Variação dos Sólidos Suspensos Totais nos ensaios de ozônio/UV.

$\mathrm{Na}$ Tabela 5.38 observa-se a análise estatística para os dados de sólidos suspensos totais antes e após a ozonização.

Tabela 5.38: Análise estatística dos SST do efluente bruto e do efluente ozonizado.

\begin{tabular}{lrr}
\hline & \multicolumn{1}{c}{$E B$} & \multicolumn{1}{c}{$E O$} \\
\hline Média & 165 & 76 \\
Erro padrão & 33,6975 & 15,1133 \\
Mediana & 141,85 & 58,825 \\
Desvio padrão & 116,7318 & 52,3540 \\
Variância da & & \\
amostra & 13626,31 & 2740,95 \\
Curtose & 4,3824 & 0,4392 \\
Assimetria & 1,8290 & 0,9644 \\
Intervalo & 428,65 & 176,8 \\
Mínimo & 47,75 & 14 \\
Máximo & 476,4 & 190,8 \\
Soma & 1976,95 & 916 \\
Contagem & 12 & 12 \\
\hline
\end{tabular}

\subsubsection{Cinética de desinfecção com ozônio}

\subsubsection{Inativação de $C$. perfringens, coliformes totais e $E$. coli na desinfecção somente com ozônio}

$\mathrm{Na}$ Figura 5.25, estão representados os valores observados experimentalmente no ensaio de desinfecção com ozônio para $C$. perfringens, e os valores estimados correspondentes obtidos pela equação ajustada com $\mathrm{R}^{2}$ de 0,7339 (equação 5.13). 


$$
\frac{N}{N o}=\exp [-0,0124(C T)]
$$

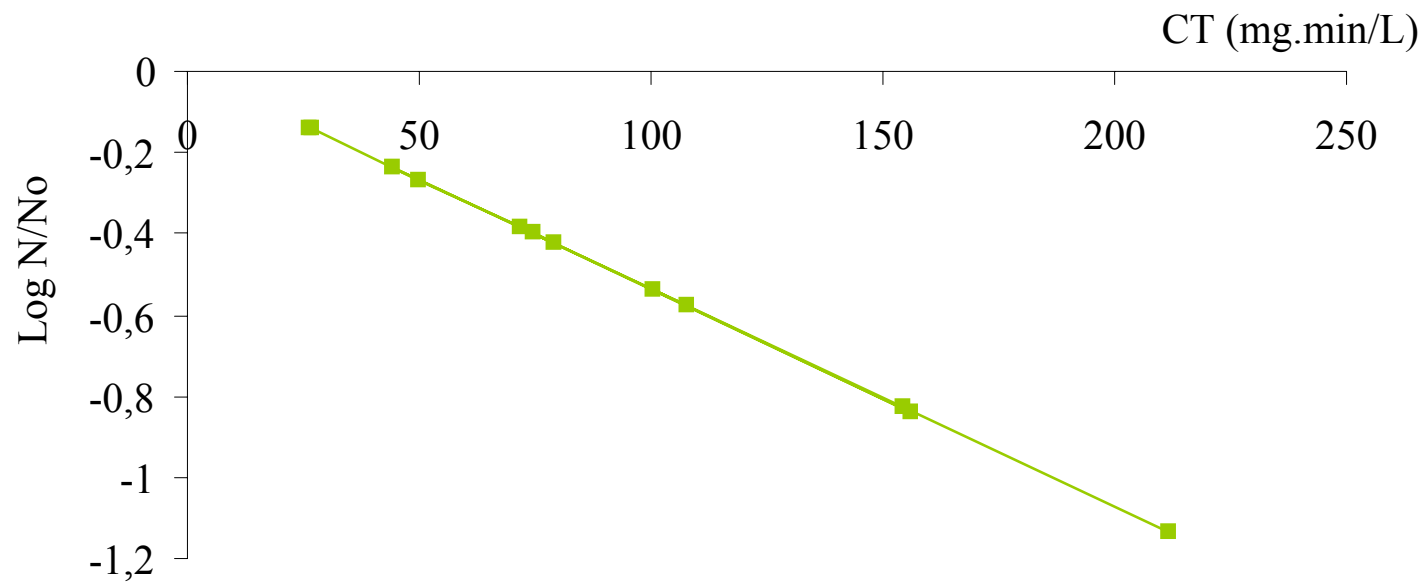

$-\log$ N/No estimado

Figura 5.25: Inativação de $C$. perfringens na desinfecção somente com ozônio.

Observa-se através dos resultados estimados (ajustados) que a maior remoção de $C$. perfringens no maior $\mathrm{CT}$ estudado foi de 1,14 log.

Na Figura 5.26 estão representados os valores observados e estimados para os ensaios de desinfecção com ozônio para os coliformes totais. A equação que apresentou melhor ajuste foi a (5.14) com $\mathrm{R}^{2}$ de 0,5724 .

$$
\frac{N}{N o}=\exp [-0,0237(C T)]
$$

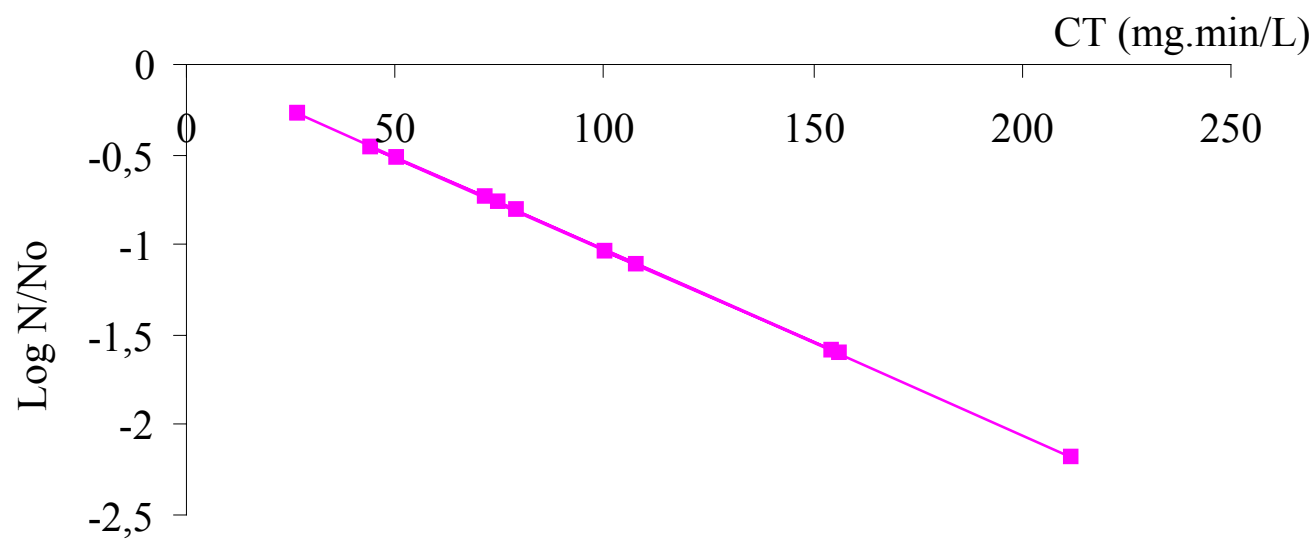

$\rightarrow-\log$ N/No estimado

Figura 5.26: Inativação de coliformes totais na desinfecção com ozônio somente. 
Na Figura 5.27 estão disponíveis os dados observados e estimados para a E. coli nos ensaios com ozônio. A equação que apresentou melhor ajuste foi a (5.15) com $\mathrm{R}^{2}=0,53915$.

$$
\frac{N}{N o}=\exp [-0,02747(C T)]
$$

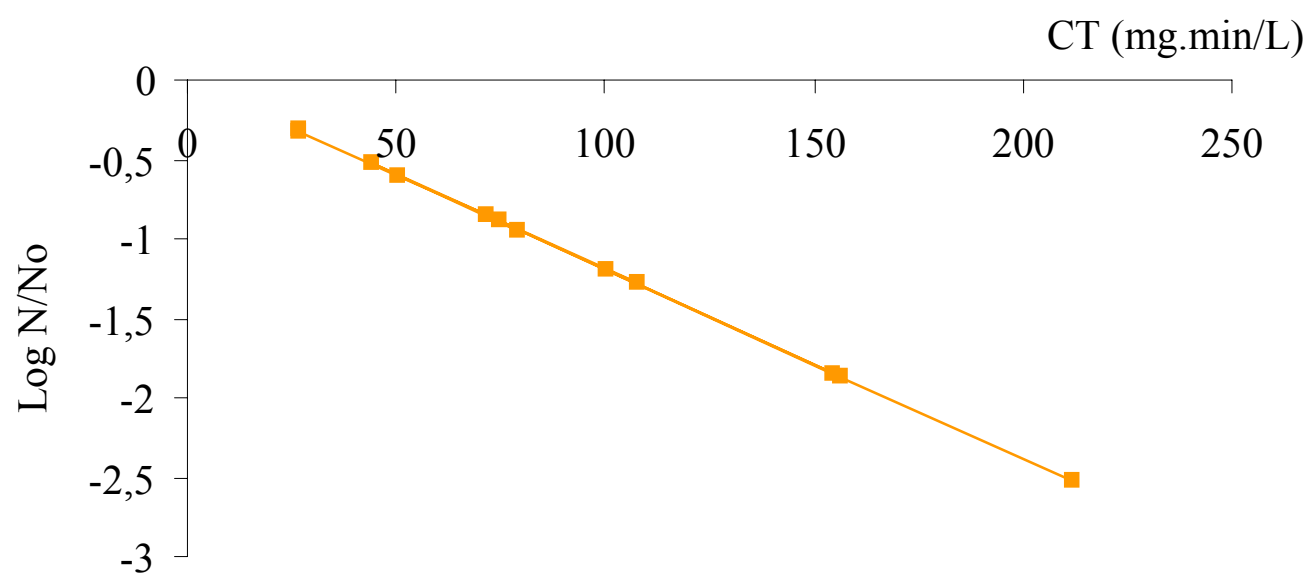

$\rightarrow-\log$ N/No estimado

Figura 5.27: Inativação de E. coli na desinfecção somente com ozônio.

A constante de inativação da $E$. coli apresentou valor semelhante àquela obtida na inativação dos coliformes totais de 0,027 e $0,023 \mathrm{~L} \cdot \mathrm{mg}^{-1} \cdot \mathrm{min}^{-1}$ respectivamente, sendo praticamente duas vezes maior que a do C. perfringens, que foi de $0,012 \mathrm{~L} \cdot \mathrm{mg}^{-1} \cdot \mathrm{min}^{-1}$.

Consequentemente, para o maior CT aplicado de ozônio (211 mg.min/L) foram inativados 1,$13 ; 2,18$ e 2,52 log de Clostridium, coliformes totais e E. coli, respectivamente. A bactéria formadora de esporo tem resistência superior à desinfecção com ozônio seguido de coliformes e E. coli, sendo essa última a bactéria mais sensível ao ozônio, assim como foi apresentado para desinfecção com hipoclorito de sódio.

\subsubsection{Inativação de $C$. perfringens, coliformes totais e $E$. coli na desinfecção sequencial}

Os resultados da desinfecção sequencial de ozônio com a radiação UV estão representados nas FigurasFigura 5.28 a 5.31. Foi realizado apenas um ensaio para se comparar a desinfecção sequencial com a desinfecção 'convencional', ou seja, aplicando-se apenas a radiação UV. Esse ensaio de comparação foi representado pelos experimentos 0-A (sequencial: ozônio seguido de UV) e 0-B (somente UV). Os demais ensaios foram realizados para desinfecção sequencial. 
Comparando-se os ensaios 0-A e 0-B (Figura 5.28), observa-se claramente que a inativação do $C$. perfringens é maior na desinfecção sequencial, atingindo 2,76 log quando sujeito à dose de $5 \mathrm{Wh} / \mathrm{m}^{3}$, contra $1,46 \log$ quando exposto apenas ao UV. O mesmo é observado para as outras bactérias estudadas, ou seja, a desinfecção sequencial superou a desinfecção utilizando-se somente UV.
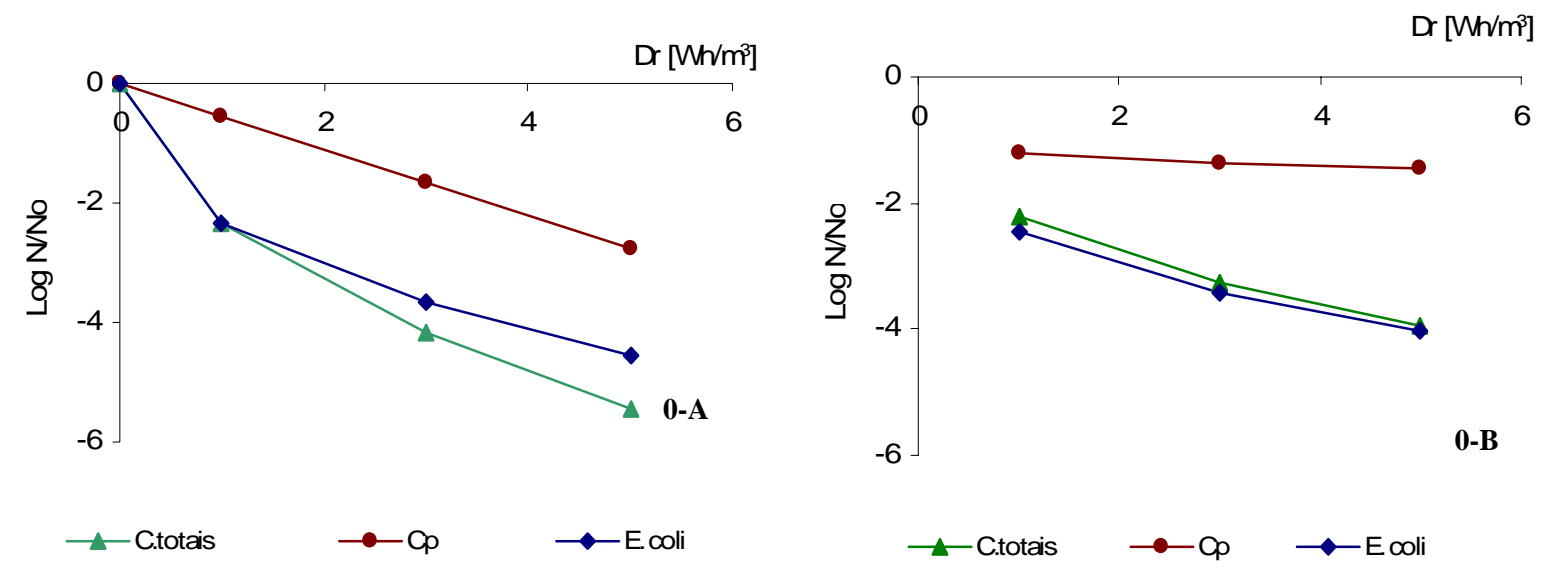

Figura 5.28: Inativação de $C$. perfringens, coliformes totais e $E$. coli no ensaio de desinfecção sequencial de ozônio seguido de UV (0-A) e somente UV (0-B).

De uma maneira geral, como representado na Figura 5.29, observa-se que o $C$. perfringens é mais resistente nos quatros ensaios cuja dosagem aplicada de ozônio foi de 5,6 $\mathrm{mgO}_{3} / \mathrm{L}$. A E. coli apresentou-se menos resistente que os coliformes totais no ensaio I, porém nos ensaios II, III-A e III- B, os coliformes totais foram os organismos mais sensíveis à desinfecção sequencial, quando aplicado $5,6 \mathrm{mgO}_{3} / \mathrm{L}$ para os três tempos de contato estudados $(10,20$ e $30 \mathrm{~min})$ e para as doses de radiação aplicados. 

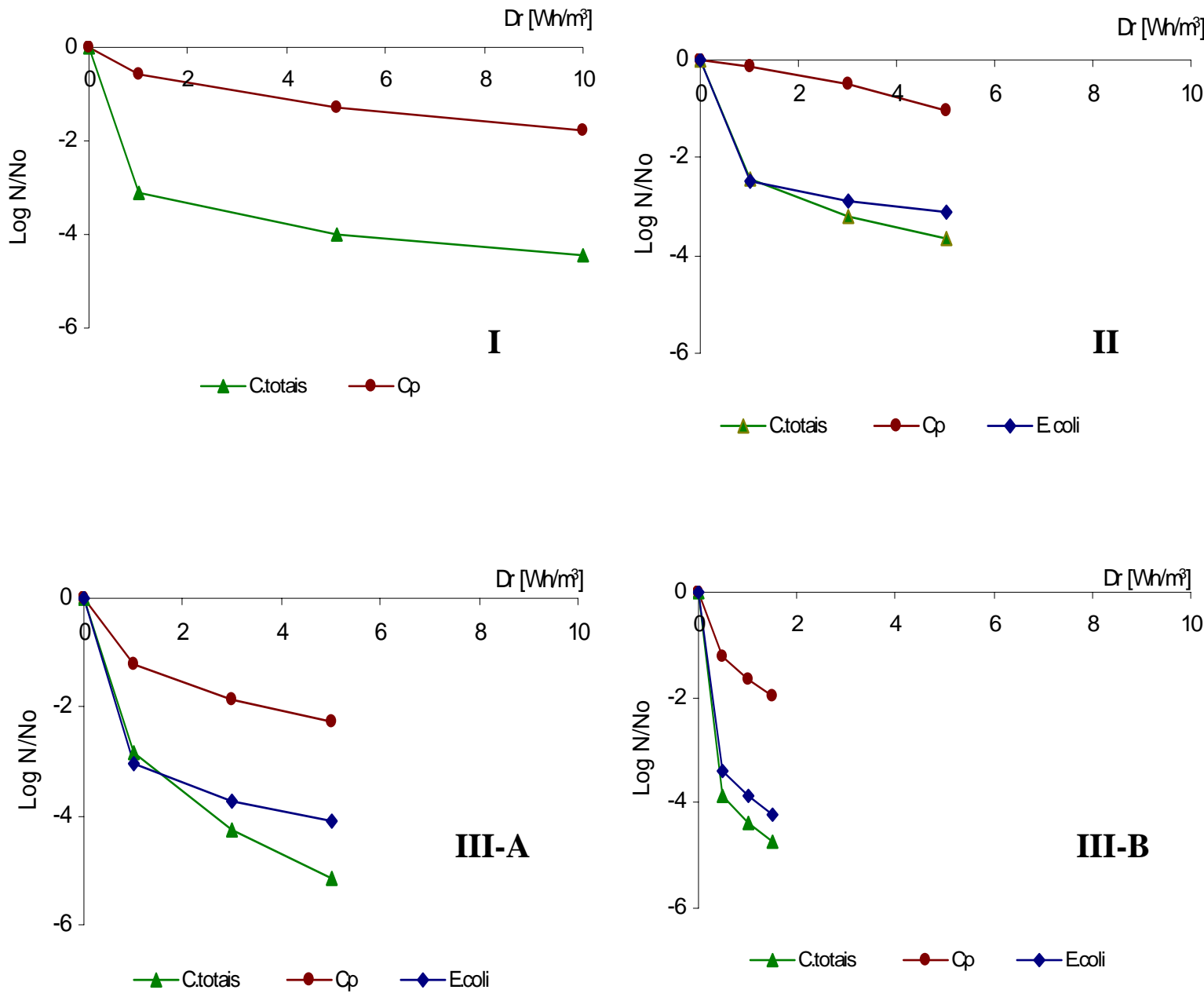

Figura 5.29: Inativação de $C$. perfringens, coliformes totais e $E$. coli na desinfecção sequencial de ozônio seguido de UV para a dose os experimentos I, II, III-A e III-B, para a dose de $5,6 \mathrm{mgO}_{3} / \mathrm{L}$.

Na Figura 5.30 pode-se observar que como regra, que o $C$. perfringens apresenta-se mais resistente que todas as outras bactérias estudadas neste trabalho. No entanto, no ensaio IV essas bactérias não resistiram à desinfecção sequencial com dose de UV maior que $1 \mathrm{Wh} / \mathrm{m}^{3}$. No ensaio $\mathrm{V}-\mathrm{A}$, os coliformes totais apresentaram-se mais resistentes que a $E$. coli, em V-B a E.coli apresentou-se mais resistente que os coliformes totais e em VI ambas apresentaram comportamento semelhante quanto a sensibilidade à desinfecção como ozônio seguido de UV. 

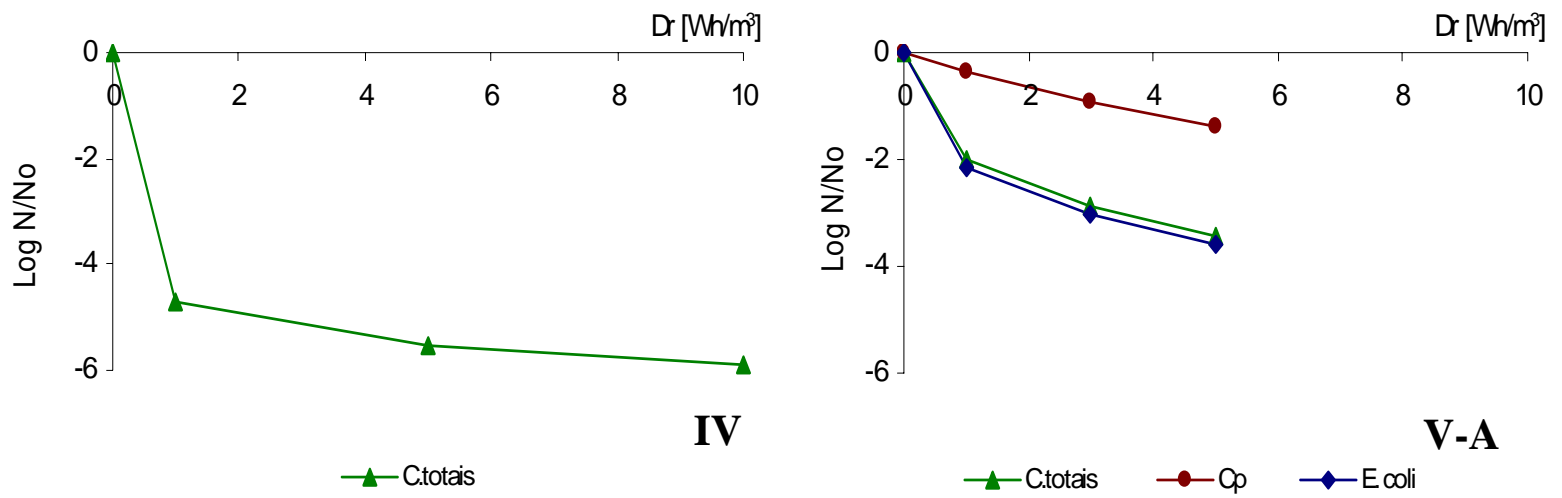

V
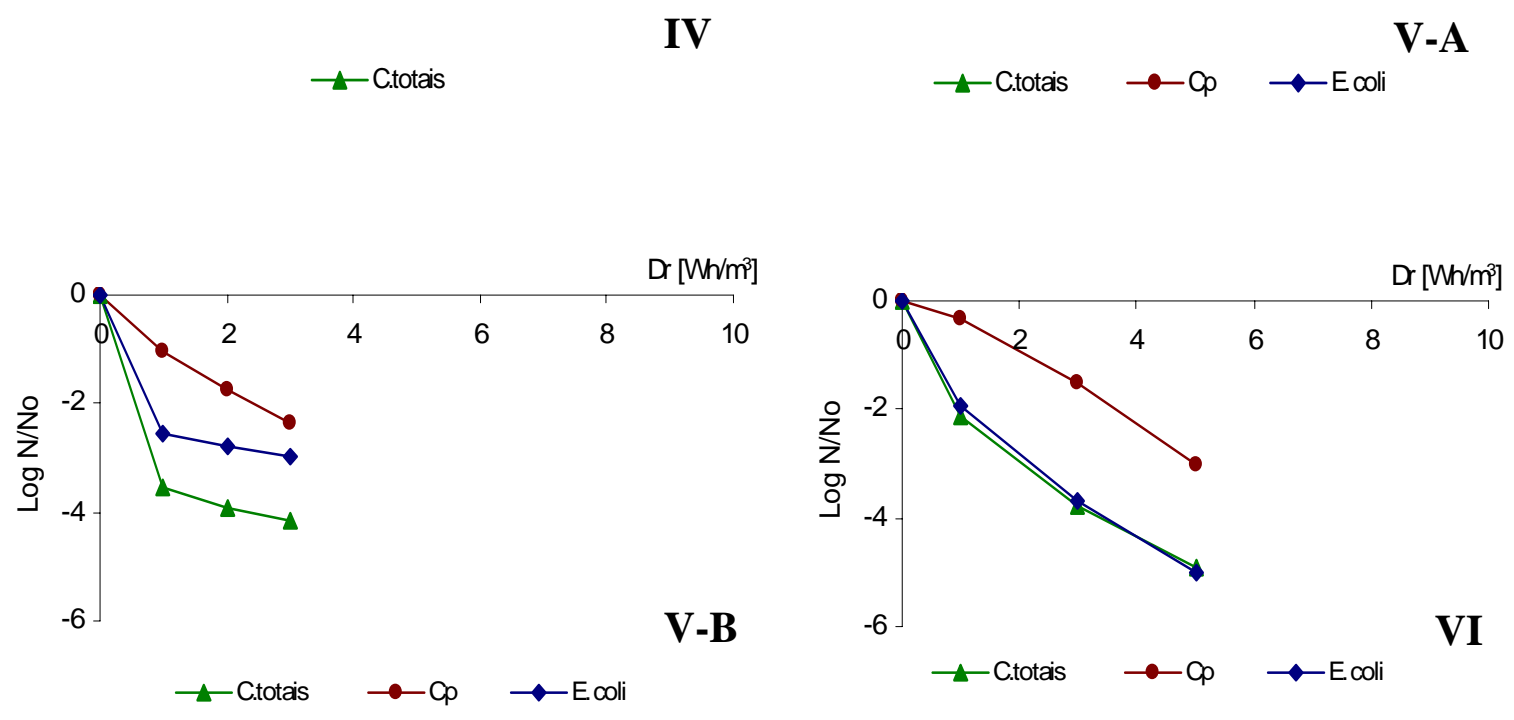

Figura 5.30: Inativação de $C$. perfringens, coliformes totais e E. coli para desinfecção sequencial de ozônio seguido de radiação UV para os ensaios IV, V-A; V-B e VI.

No ensaio V-B, a E. coli atingiu 2,8 log de remoção com a menor dose de UV utilizada $\left(1 \mathrm{Wh} / \mathrm{m}^{3}\right)$ e os coliformes totais apresentaram 3,9 log de remoção quando expostos, também, à menor dose.

$\mathrm{Na}$ Figura 5.31, observa-se o mesmo padrão decrescente de resistência $C$. perfringens $>$ E. coli $>$ coliformes totais para os experimentos VII, VIII e IX. 


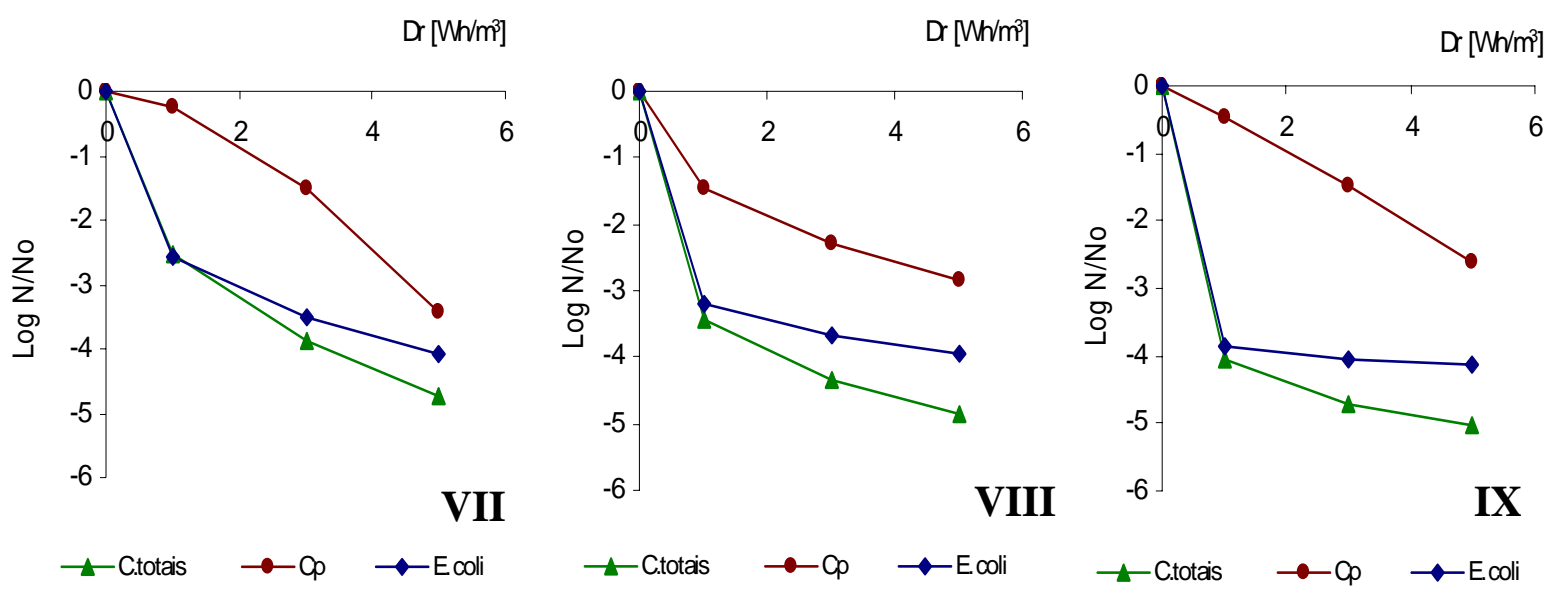

Figura 5.31: Inativação de $C$. perfringens, coliformes totais e $E$. coli nos ensaios de desinfecção sequencial de ozônio seguido de UV para os experimentos VII, VIII e IX.

Excepcionalmente, nos ensaios realizados nos experimentos V-A e VI (Figura 5.30), ocorreu menor resistência à desinfecção por parte da $E$. coli em relação aos coliformes totais.

Para o modelo de Watson, no qual acrescenta-se o coeficiente $\mathrm{n}$ como expoente da dose recebida (Dr), observa-se maior velocidade de inativação para o $C$. perfringens quando aplicado apenas radiação UV (comparando os ensaios O-A e O-B). Observa-se grande variação dos parâmetros cinéticos quando na ausência ou na presença do coeficiente $n$ na equação de decaimento das bactérias (Tabela 5.39).

Observa-se nas TabelasTabela 5.39 a 5.41 que os melhores ajustes $\left(\mathrm{R}^{2}\right)$ ocorrem para o modelo de Watson. $\mathrm{O}$ maior $\mathrm{R}^{2}$ foi o fator preponderante para escolher este modelo para basear a discussão da inativação dos microrganismos. 
Tabela 5.39: Parâmetros cinéticos obtidos nos ensaios de desinfecção seqüencial ozônio-UV para C. perfringens.

\begin{tabular}{cccccc}
\hline & \multicolumn{2}{c}{ Chick } & \multicolumn{3}{c}{ Watson } \\
Experimento & $\mathrm{K}\left(\mathrm{m}^{3} / \mathrm{Wh}\right)$ & $\mathrm{R}^{2}$ & $\mathrm{~K}^{\prime}\left(\mathrm{m}^{3} / \mathrm{Wh}\right)$ & $\mathrm{n}$ & $\mathrm{R}^{2}$ \\
\hline 0-A & 1,2513 & 0,9732 & 1,3132 & 0,9806 & 0,9885 \\
0-B & 1,1324 & 0,9003 & 2,8225 & 0,1103 & 0,9224 \\
I & 0,4327 & 0,8301 & 1,3681 & 0,4725 & 0,9139 \\
II & 0,4891 & 0,8895 & 0,2637 & 1,3594 & 0,9139 \\
III-A & 1,2036 & 0,9196 & 2,7808 & 0,3946 & 0,9900 \\
III-B & 3,5391 & 0,8595 & 3,7947 & 0,4402 & 0,6108 \\
IV & & & & & \\
V-A & 0,6383 & 0,9852 & 0,8473 & 0,8158 & $1 *$ \\
V-B & 1,9117 & 0,9572 & 2,4141 & 0,7467 & 0,9732 \\
VI & 1,2549 & 0,9837 & 0,8043 & 1,3406 & 0,9738 \\
VII & 1,3138 & 0,9122 & 0,5964 & 1,6078 & 0,9035 \\
VIII & 1,5040 & 0,9128 & 3,3946 & 0,4082 & 0,9712 \\
IX & 1,1519 & 0,9971 & 1,0334 & 1,0904 & 0,9916 \\
\hline
\end{tabular}

* conjunto de dados com apenas dois pontos

Tabela 5.40: Parâmetros cinéticos obtidos nos ensaios de desinfecção seqüencial ozônio-UV para coliformes totais.

\begin{tabular}{cccccc}
\hline & \multicolumn{2}{c}{ Chick } & \multicolumn{3}{c}{ Watson } \\
Experimento & $\mathrm{K}\left(\mathrm{m}^{3} / \mathrm{Wh}\right)$ & $\mathrm{R}^{2}$ & $\mathrm{~K}^{\prime}\left(\mathrm{m}^{3} / \mathrm{Wh}\right)$ & $\mathrm{n}$ & $\mathrm{R}^{2}$ \\
\hline 0-A & 2,7334 & 0,9426 & 5,3804 & 0,5260 & 0,9651 \\
0-B & 2,0579 & 0,8853 & 5,1067 & 0,3556 & 0,8270 \\
I & 0,5362 & 0,7697 & 7,1928 & 0,1514 & 0,9908 \\
II & 1,1563 & 0,8174 & 5,5807 & 0,2549 & 0,9332 \\
III-A & 2,7006 & 0,8878 & 6,5316 & 0,3722 & 0,9352 \\
III-B & 8,8132 & 0,8535 & 10,1055 & 0,1799 & 0,9831 \\
IV & 1,6534 & 0,6974 & 10,8732 & 0,0971 & 0,7714 \\
V-A & 1,1302 & 0,8861 & 4,6538 & 0,3276 & 0,9978 \\
V-B & 3,9270 & 0,7931 & 8,1778 & 0,1425 & 0,9655 \\
VI & 2,4527 & 0,9249 & 4,8994 & 0,5192 & 0,9067 \\
VII & 2,4664 & 0,9209 & 5,7977 & 0,3904 & 0,9833 \\
VIII & 2,6752 & 0,8114 & 7,9374 & 0,2123 & 0,9865 \\
IX & 2,8417 & 0,7962 & 9,3369 & 0,1342 & 0,9437 \\
\hline
\end{tabular}


Tabela 5.41: Valores dos parâmetros cinéticos obtidos nos ensaios de desinfecção seqüencial de ozônio-UV para E. coli.

\begin{tabular}{|c|c|c|c|c|c|}
\hline \multirow[b]{2}{*}{ Experimento } & \multicolumn{2}{|c|}{ Chick } & \multicolumn{3}{|c|}{ Watson } \\
\hline & $\mathrm{K}\left(\mathrm{m}^{3} / \mathrm{Wh}\right)$ & $\mathrm{R}^{2}$ & $\mathrm{~K}^{\prime}\left(\mathrm{m}^{3} / \mathrm{Wh}\right)$ & $\mathrm{n}$ & $\mathrm{R}^{2}$ \\
\hline $0-\mathrm{A}$ & 2,3449 & 0,9102 & 5,3552 & 0,4174 & 0,9035 \\
\hline $0-\mathrm{B}$ & 2,1370 & 0,8891 & 5,6333 & 0,3067 & 0,9155 \\
\hline I & & & & & \\
\hline II & 0,9602 & 0,7823 & 5,7031 & 0,1459 & 0,9793 \\
\hline III-A & 2,2789 & 0,8081 & 7,0237 & 0,1841 & 0,9552 \\
\hline III-B & 7,8946 & 0,7824 & 8,9520 & 0,1947 & 0,6108 \\
\hline IV & & & & & \\
\hline V-A & 1,1633 & 0,8716 & 5,0162 & 0,3064 & 0,9921 \\
\hline V-B & 2,8258 & 0,7148 & 5,8272 & 0,1487 & 0,6108 \\
\hline VI & 2,4861 & 0,9670 & 4,4243 & 0,5961 & 0,9917 \\
\hline VII & 2,2015 & 0,8979 & 5,9269 & 0,2854 & 0,9979 \\
\hline VIII & 2,2260 & 0,7532 & 7,3664 & 0,8823 & 0,1295 \\
\hline IX & 2,4076 & 0,6937 & 8,8490 & 0,0476 & 0,4046 \\
\hline
\end{tabular}

\subsubsection{Influência do tempo de contato com ozônio na inativação de $C$. perfringens, coliformes totais e $\boldsymbol{E}$. coli.}

A influência do tempo de contato do ozônio na desinfecção seqüencial com radiação UV está representada nas Figura 5.32 a 5.34.

Para dosagem de ozônio de 5,6 $\mathrm{mgO}_{3} / \mathrm{L}$ (Figura 5.32), o decaimento no número de sobreviventes de $C$. perfringens foi mais acentuado quando exposto ao tempo de contato de 30 minutos. Entretanto, para essa mesma dosagem de ozônio, a exposição a este gás por 10 minutos forneceu inativação superior a 20 minutos.

Quando foi aplicado aproximadamente $11 \mathrm{mgO}_{3} / \mathrm{L}$, a exposição dessa bactéria ao tempo de contato de 10 minutos ao ozônio antecedendo a radiação UV promoveu $100 \%$ de remoção, e 20 minutos surtiu maior efeito do que quando ozônio foi aplicado durante 30 minutos.

E por fim, quando foi aplicado ozônio em $16 \mathrm{mgO}_{3} / \mathrm{L}$ o $C$. perfringens apresentou remoção superior quando exposto por 10 minutos ao gás, do que com a remoção obtida na exposição de 20 e 30 minutos na maior dose de UV $\left(5 \mathrm{Wh} / \mathrm{m}^{3}\right)$. 
$5,6 \mathrm{mgO}_{3} / \mathrm{L}$

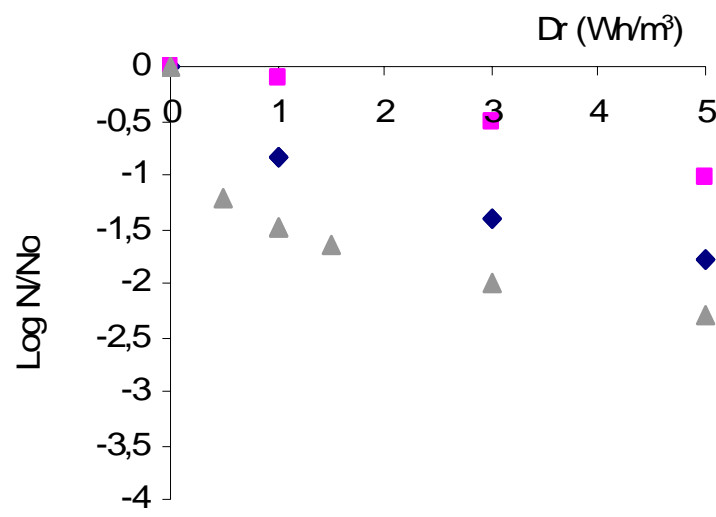

$11 \mathrm{mgO} / \mathrm{L}$

$\mathrm{Dr}\left(\mathrm{W} / \mathrm{m}^{3}\right)$

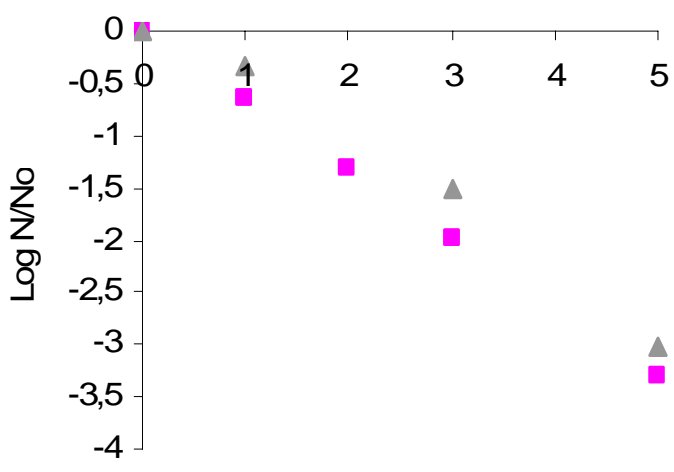

- 20 min $\triangle 30$ min

- $10 \min \quad 20 \min \Delta 30 \min$

$16 \mathrm{mg} \mathrm{O} / \mathrm{L}$

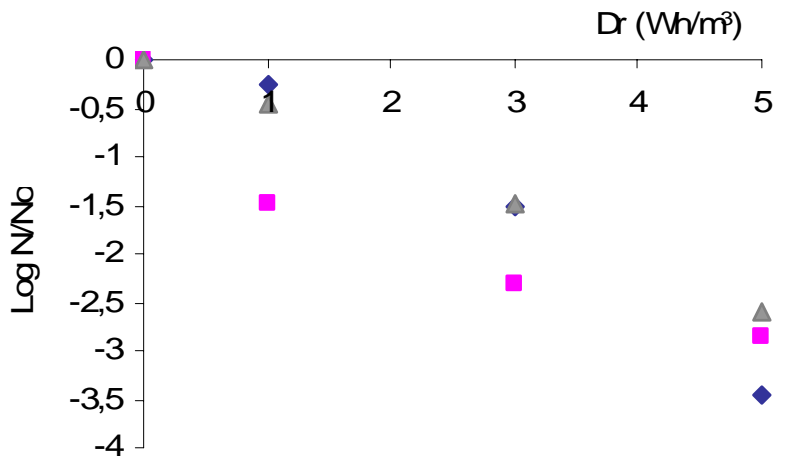

- $10 \min 20 \mathrm{~min} \quad \Delta 30 \mathrm{~min}$

Figura 5.32: Influência do tempo de contato do ozônio na inativação do $C$. perfringens para desinfecção sequencial de ozônio seguido de UV.

Para os coliformes totais, a Figura 5.33 mostra que na menor dose aplicada de ozônio (5,6 $\left.\mathrm{mgO}_{3} / \mathrm{L}\right)$ ocorreu o mesmo padrão ilustrado na mesma dose de ozônio para o $C$. perfringens, onde a exposição a este gás pelo tempo de contato de 30 minutos foi mais eficiente do que em 10 e 20 minutos, sendo que no tempo de contato de 10 minutos a remoção de coliformes totais foi superior ao tempo de contato de 20 minutos que antecedeu a radiação UV.

Os coliformes totais apresentaram, após a desinfecção com $11 \mathrm{mgO}_{3} / \mathrm{L}$ e em todas as doses de UV pesquisadas, maior remoção quando expostos por 10 minutos ao gás ozônio 
antecedendo a radiação UV. Isso evidencia que, para a concentração estudada e para as condições de qualidade da água residuária pesquisada, 10 minutos de exposição a $11 \mathrm{mgO}_{3} / \mathrm{L}$ e para baixas doses de UV esses microrganismos são satisfatoriamente removidos.

Quando o ozônio foi aplicado na concentração de $16 \mathrm{mgO}_{3} / \mathrm{L}$, a remoção foi inferior ou igual à remoção observada quando foi aplicado $11 \mathrm{mgO}_{3} / \mathrm{L}$. Visualiza-se também que quando foi aplicado a maior dose de ozônio e quanto maior foi o tempo de exposição ao ozônio antecedendo a radiação UV maiores foram as remoções dos coliformes totais (Figura $5.33)$.

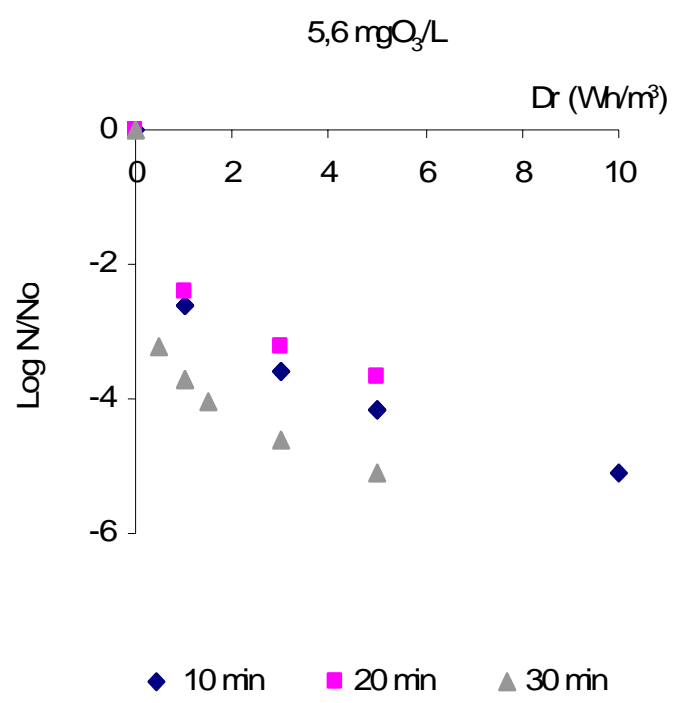

$11 \mathrm{mgO}_{3} / \mathrm{L}$

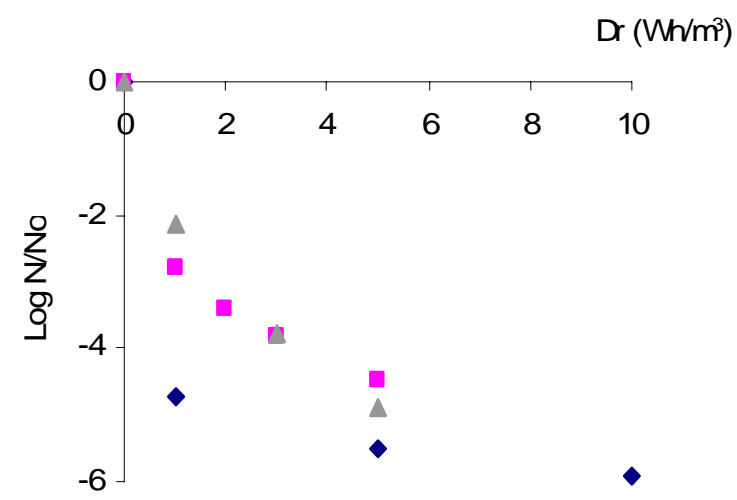

$\bullet 10 \min \quad-20 \min \Delta 30 \mathrm{~min}$

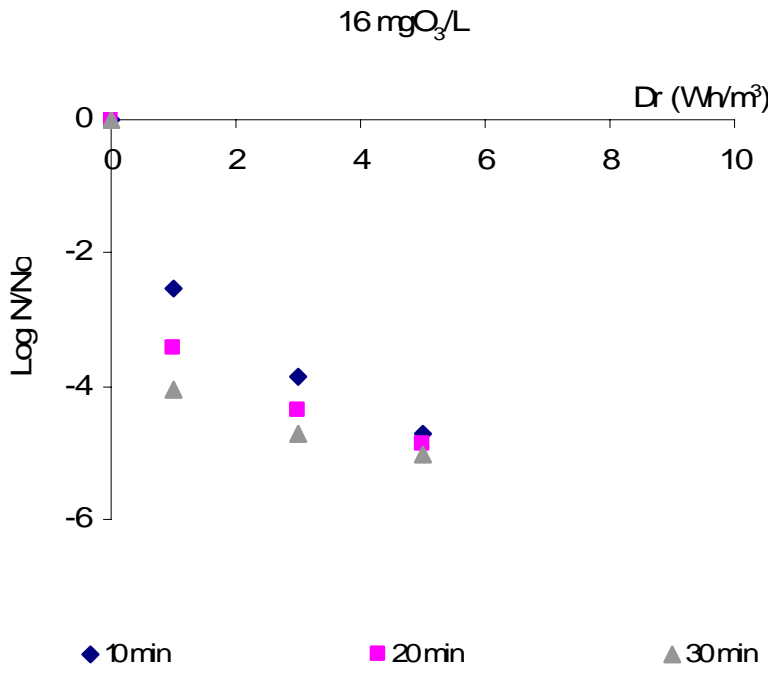

Figura 5.33: Influência do tempo de contato com ozônio na inativação de coliformes totais na desinfecção sequencial de ozônio seguido de UV.

Na Figura 5.34, verifica-se o comportamento da $E$. coli na desinfecção sequencial. Observa-se novamente que na menor dose de ozônio precedendo a radiação UV $\left(5,6 \mathrm{mgO}_{3} / \mathrm{L}\right)$ a inativação dessa bactéria foi maior quando exposta ao tempo de contato de 30 minutos com 
ozônio do que em 20 minutos. Nessa condição de menor dosagem de ozônio 10 minutos de exposição foi mais eficiente do que 30 e 20 minutos.

É possível observar que quando se aplica $11 \mathrm{mgO}_{3} / \mathrm{L}$, a remoção é total em 10 minutos de exposição ao ozônio, e 20 minutos fornecem remoção superior a verificada para 30 minutos nas menores doses de UV $\left(1\right.$ e $\left.3 \mathrm{Wh} / \mathrm{m}^{3}\right)$.

E por fim, quando foi aplicado $16 \mathrm{mgO}_{3} / \mathrm{L}$ por 20 minutos de tempo de contato foi verificado maior inativação de $E$. coli quando o tempo de contato com o ozônio antecedendo a radiação UV foi de 20 minutos.

$5,6 \mathrm{mg} \mathrm{O} / \mathrm{L}$

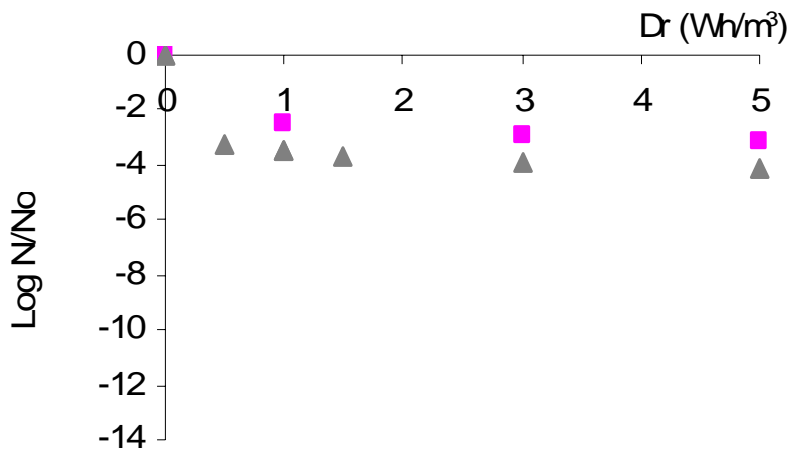

$11 \mathrm{mg} \mathrm{O} / \mathrm{L}$

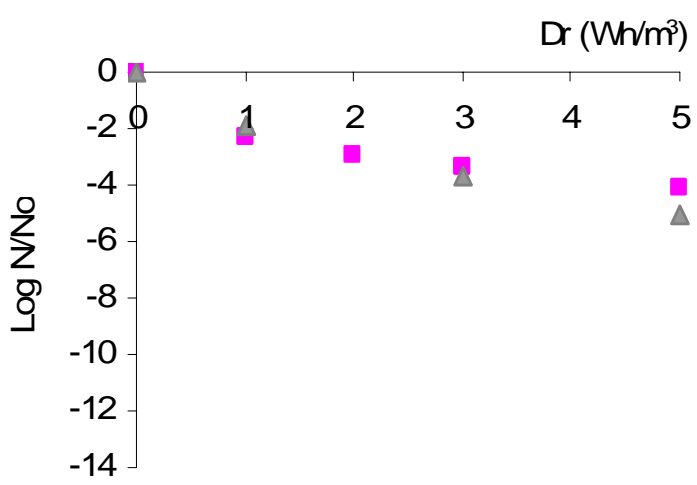

- $20 \min \triangle 30 \min$

- $20 \min \quad \Delta 30 \min$

$16 \mathrm{mgO}_{3} / \mathrm{L}$

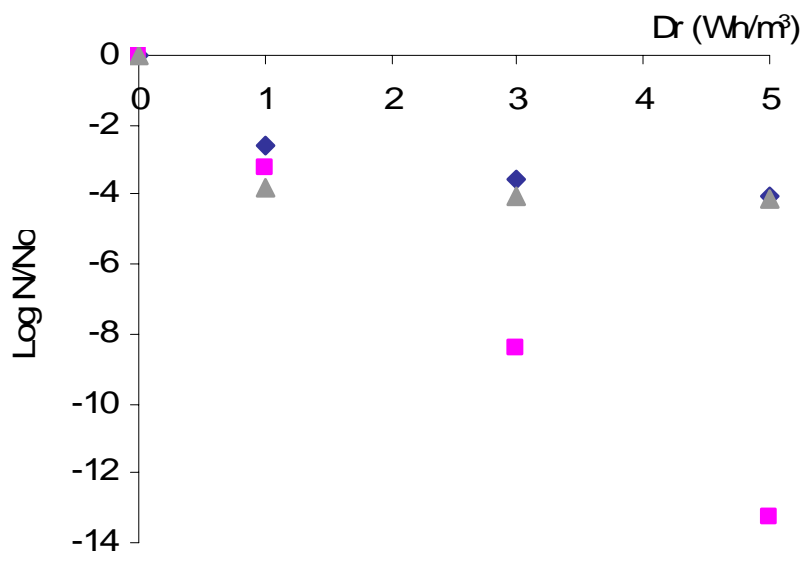

$\bullet$ Dmin $\quad$-20min $\quad \Delta 30 \min$

Figura 5.34: Influência do tempo de contato do ozônio na inativação de E. coli na desinfecção sequencial de ozônio seguido de UV. 


\subsubsection{Influência dos sólidos suspensos totais na inativação dos microrganismos indicadores}

$\mathrm{Na}$ Tabela 5.42, encontram-se, para a maioria dos ensaios realizados, os valores de absorbância em $\lambda 254 \mathrm{~nm}$ para as amostras brutas e para as ozonizadas. Observa-se a diminuição destes valores após a ozonização, mostrando a alteração que o ozônio pode promover no material orgânico ou inorgânico presente nas amostras. A alteração que o ozônio promove na amostra pode ser pelo motivo da oxidação, ou até mesmo de remoção física através da espuma formada devido ao borbulhamento do gás. Assim como foi discutido para o cloro, os tempos de contato para a determinação da radiação UV recebida é dependente deste valor de absorbância em $\lambda 254 \mathrm{~nm}$. 
Tabela 5.42: Valores de absorbância a 254nm, Im, dose de UV e tempo de contato dos experimentos de desinfecção com ozônio seguido de UV.

\begin{tabular}{|c|c|c|c|c|c|}
\hline \multirow[b]{2}{*}{ Experimento $^{(1)}$} & \multicolumn{2}{|c|}{ Abs $254 \mathrm{~nm}^{(2)}$} & \multirow[b]{2}{*}{$\mathrm{I}_{\mathrm{m}}^{\left({ }^{(3)}\right.}$} & \multirow{2}{*}{$\begin{array}{c}\text { Dose } \\
\text { recebida } \\
\left(\mathrm{Wh} / \mathrm{m}^{3}\right)\end{array}$} & \multirow{2}{*}{$\begin{array}{c}\text { Tempo de } \\
\text { contato }^{(5)}(\mathrm{s})\end{array}$} \\
\hline & $\begin{array}{c}\text { efluente } \\
\text { UASB }\end{array}$ & $\begin{array}{c}\text { efluente } \\
\text { ozonizado }\end{array}$ & & & \\
\hline \multirow{3}{*}{$\mathrm{O}-\mathrm{A}\left(5,6 \mathrm{mgO}_{3} / \mathrm{L} ; 10 \mathrm{~min}\right)$} & \multirow{3}{*}{0,92} & \multirow{3}{*}{0,759} & \multirow{3}{*}{0,59539} & 1 & 18,14 \\
\hline & & & & 3 & 54,418 \\
\hline & & & & 5 & 90,69 \\
\hline \multirow{3}{*}{ O-B só UV } & \multirow{3}{*}{0,92} & \multirow{3}{*}{ - } & \multirow{3}{*}{0,49295} & 1 & 21,91 \\
\hline & & & & 3 & 65,72 \\
\hline & & & & 5 & 109,53 \\
\hline \multirow{3}{*}{ I $\left(5,6 \mathrm{mgO}_{3} / \mathrm{L} ; 10 \mathrm{~min}\right)$} & \multirow{3}{*}{ NA } & \multirow{3}{*}{0,561} & \multirow{3}{*}{0,82365} & 1 & 13,11 \\
\hline & & & & 5 & 65,56 \\
\hline & & & & 10 & 131,11 \\
\hline \multirow{3}{*}{ II $\left(5,6 \mathrm{mgO}_{3} / \mathrm{L} ; 20 \mathrm{~min}\right)$} & \multirow{3}{*}{1,092} & \multirow{3}{*}{0,921} & \multirow{3}{*}{0,49242} & 1 & 21,93 \\
\hline & & & & 3 & 65,79 \\
\hline & & & & 5 & 109,65 \\
\hline \multirow{3}{*}{$\mathrm{III}-\mathrm{A}\left(5,6 \mathrm{mgO}_{3} / \mathrm{L} ; 30 \mathrm{~min}\right)$} & \multirow{3}{*}{1,38} & \multirow{3}{*}{0,981} & \multirow{3}{*}{0,46257} & 1 & 23,35 \\
\hline & & & & 3 & 70,04 \\
\hline & & & & 5 & 116,73 \\
\hline \multirow{3}{*}{ III-B $\left(5,6 \mathrm{mgO}_{3} / \mathrm{L} ; 30 \mathrm{~min}\right)$} & & & & 0,5 & 10,59 \\
\hline & NA & 0,501 & 0,50973 & 1 & 21,19 \\
\hline & & & & 1,5 & 31,78 \\
\hline & & & & 1 & 17,66 \\
\hline $\operatorname{IV}\left(10,5 \mathrm{mgO}_{3} / \mathrm{L} ; 10 \mathrm{~min}\right)$ & NA & 0,768 & 0,61134 & 5 & 88,32 \\
\hline & & & & 10 & 176,65 \\
\hline & & & & 1 & 19,4 \\
\hline $\mathrm{V}-\mathrm{A}\left(11,1 \mathrm{mgO}_{3} / \mathrm{L} ; 20 \mathrm{~min}\right)$ & 1,072 & 0,813 & 0,55677 & 3 & 58,19 \\
\hline & & & & 5 & 96,98 \\
\hline & & & & 1 & 15,6 \\
\hline $\mathrm{V}-\mathrm{B}\left(11,1 \mathrm{mgO}_{3} / \mathrm{L} ; 20 \mathrm{~min}\right)$ & NA & 0,346 & 0,69221 & 2 & 31,2 \\
\hline & & & & 3 & 46,8 \\
\hline & & & & 1 & 30,1 \\
\hline VI $\left(11,1 \mathrm{mgO}_{3} / \mathrm{L} ; 20 \mathrm{~min}\right)$ & 1,877 & 1,266 & 0,35879 & 3 & 90,29 \\
\hline & & & & 5 & 150,49 \\
\hline & & & & 1 & 39,17 \\
\hline VII $\left(15,8 \mathrm{mgO}_{3} / \mathrm{L} ; 10 \mathrm{~min}\right)$ & 2,518 & 1,648 & 0,27567 & 3 & 117,52 \\
\hline & & & & 5 & 195,87 \\
\hline & & & & 1 & 11,09 \\
\hline $\operatorname{VIII}\left(16,7 \mathrm{mgO}_{3} / \mathrm{L} ; 20 \mathrm{~min}\right)$ & 1,429 & 0,445 & 0,97373 & 3 & 33,27 \\
\hline & & & & 5 & 55,45 \\
\hline & & & & 1 & 16,98 \\
\hline $\operatorname{IX}\left(16,7 \mathrm{mgO}_{3} / \mathrm{L} ; 30 \mathrm{~min}\right)$ & 1,191 & 0,709 & 0,63599 & 3 & 50,94 \\
\hline & & & & 5 & 84,9 \\
\hline
\end{tabular}

Nota: NA: não analisado. (1)o número dado a cada experimento e sua correspondente concentração e tempo de contato com o ozônio; (2) valores de absorbância à $254 \mathrm{~nm}$ medidos para o efluente do reator UASB, e para o efluente após a ozonização; (3) usando a equação 4.4; (4) doses fixadas; (5) usando a equação 4.6 para as doses recebidas fixadas. 
Pode-se notar que ocorre nitidamente a diminuição da absorbância com a aplicação do gás ozônio (Tabela 5.42). Para a dose de 5,6 $\mathrm{mgO}_{3} / \mathrm{L}$ houve uma diminuição da absorbância de 15 para 29\% aumentando-se o tempo de contato de 20 para 30 minutos (experimentos II e III-A). Para a dose de $11 \mathrm{mgO}_{3} / \mathrm{L}$ aplicando-se para o tempo de contato de 20 minutos, mas para amostras com características diferentes, houve diminuição da absorbância no comprimento de onda de $254 \mathrm{~nm}$ de 24 a 33\% (experimentos V-A e VI). Quando aplicado 16 $\mathrm{mgO}_{3} / \mathrm{L}$ a maior diminuição de absorbância foi para o tempo de contato de 20 minutos, com $69 \%$ de remoção (experimento VIII) seguido de 30 minutos de tempo de contato com remoção de 40\% (experimento IX), e 10 minutos com remoção de $35 \%$ (experimento VII).

Observa-se nas Figura 5.35 a 5.37 que o aumento na concentração de sólidos suspensos totais parece não interferir na inativação dos organismos estudados, mas esse fenômeno foi considerado na dose recebida de UV, visto que essa dose é dependente da absorbância a $254 \mathrm{~nm}$ assim como foi discutido para a desinfecção com cloro no item 5.1.6.4.
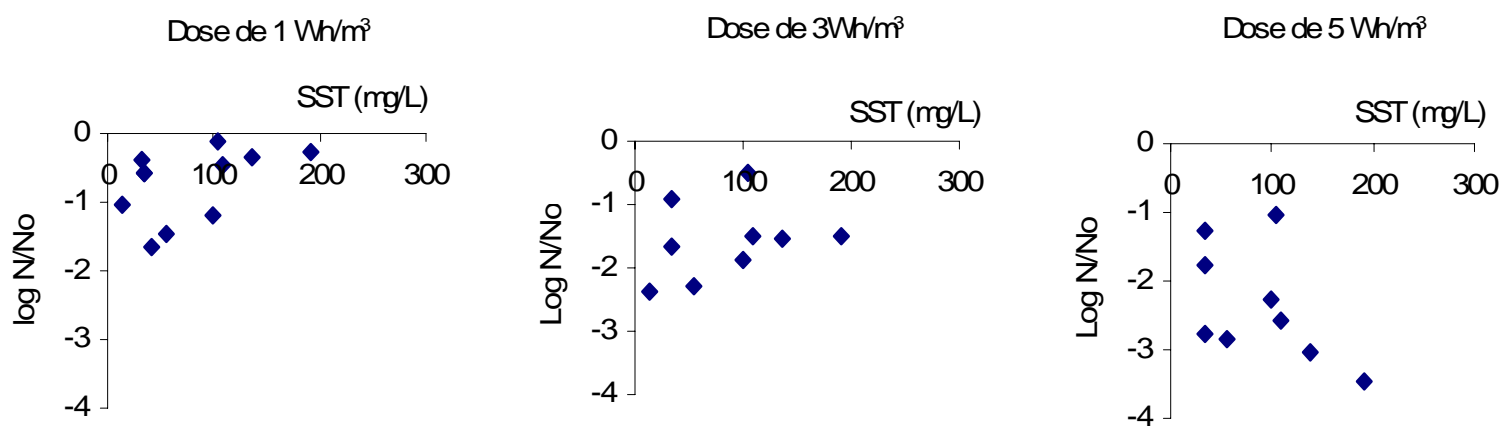

Figura 5.35: Inativação de $C$. perfringens relacionando SST para doses de UV estudadas.
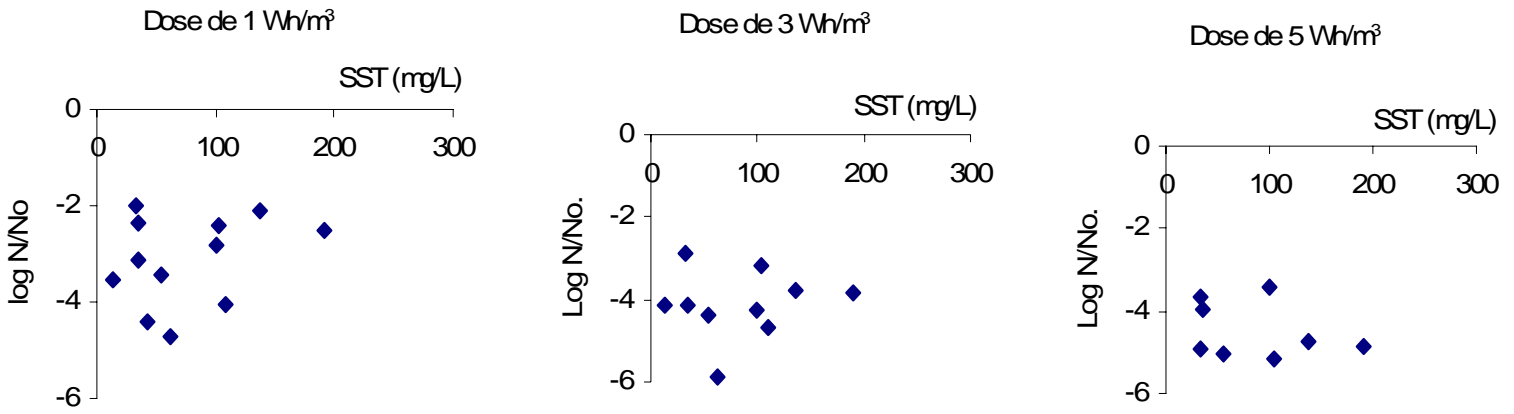

Figura 5.36: Inativação de coliformes totais relacionando SST para doses de UV estudadas. 

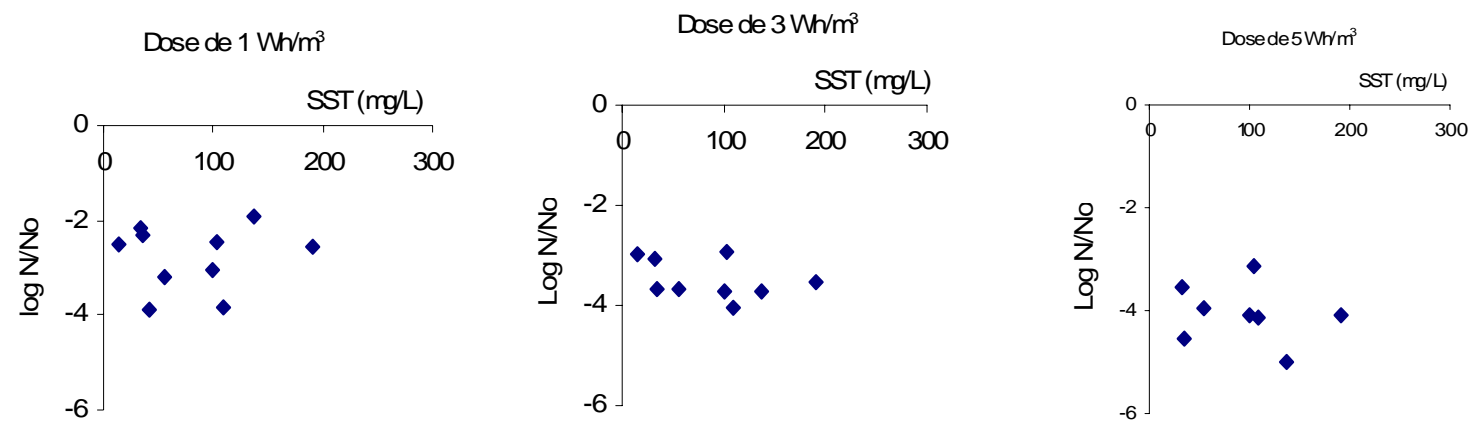

Figura 5.37: Inativação de E. coli relacionando SST para doses de UV estudadas.

\subsection{Discussão dos resultados comparando os efeitos do cloro e do ozônio sobre o efluente do reator UASB}

Após apresentados os resultados obtidos pelos experimentos realizados neste trabalho surgiu a necessidade de comparar os efeitos da aplicação dos sistemas de desinfecção pesquisados cloro-UV e ozônio-UV. A seguir estão delineadas as principais observações e inferências geradas através da análise dos dados produzidos.

\subsection{1 pH}

À respeito do $\mathrm{pH}$ observa-se para a maioria das dosagens de ozônio utilizadas que a sua aplicação provocou aumento no $\mathrm{pH}$, podendo advir da ocorrência de stripping de gás carbônico ou ainda da própria mudança estrutural causada pela a oxidação do material degradável do efluente do reator anaeróbio.

Quando comparado o efeito do cloro no $\mathrm{pH}$, observa-se que a sua aplicação provoca provavelmente uma mudança no equilíbrio iônico da amostra desinfetada, alterando de um estado acidificado quando aplicado $10 \mathrm{mgCl}_{2} / \mathrm{L}$ para um estado de $\mathrm{pH}$ mais neutro ao aumentar a dose aplicada para 20 e $30 \mathrm{mgCl}_{2} / \mathrm{L}$.

\subsubsection{DQO}

Devido ao fato de o cloro ser um forte oxidante, era de se esperar diminuição nos valores de DQO após a sua aplicação pela oxidação do material degradável presente nas amostras de efluente sanitário. Diferentemente do que era esperado a aplicação de cloro nas amostras de efluente de reator anaeróbio provocou o aumento no valor da DQO, supostamente devido à interferência do íon cloreto presente na própria amostra e presente na solução de hipoclorito de sódio utilizada na desinfecção. 
A ozonização provocou diminuição nos valores de DQO em até 60 \% quando aplicado $16 \mathrm{mgO}_{3} / \mathrm{L}$. A diminuição nos valores de DQO após a aplicação do ozônio pode ter ocorrido pela oxidação do material degradável no efluente sanitário estudado, e através da remoção mecânica de sólidos suspensos pela espuma removida pelo borbulhamento do gás na coluna de ozonização.

\subsubsection{Sólidos}

Em se tratando de sólidos totais foi observado aumento nos seus valores após a cloração do efluente do reator UASB. Esta 'geração' de sólidos totais foi explicada pelo possível incremento de sólidos através da adição da solução de cloro. Esta constatação não foi notada para as amostras ozonizadas. Ou seja, após a aplicação de ozônio ocorreu a diminuição nos valores de sólidos totais, remoção que ultrapassou 30 \%.

A causa da remoção de sólidos totais através da ozonização foi inferida pela remoção de espuma gerada ao longo da ozonização. A espuma é gerada principalmente devido a presença de detergentes no esgoto doméstico.

Em relação aos sólidos suspensos totais, a remoção pela ozonização foi grande quando comparado com os efeitos do cloro no efluente anaeróbio, alcançando valores maiores que 70 \%. Em contrapartida, não foi observada tendência de aumento ou de diminuição deste parâmetro após a aplicação de cloro. Infere-se que ocorre alteração estrutural na matriz do efluente através da cloração provocando resultados distintos para amostras distintas. Vale ressaltar que para cada experimento uma amostra, com características particulares de efluente de reator UASB, foi desinfetada causando então alterações diferenciadas após a oxidação pelo cloro.

\subsubsection{Desinfecção}

\subsubsection{Desinfecção Convencional}

Comparando a desinfecção por cloro e ozônio, sem levar em consideração a desinfecção sequencial, a ação do cloro foi superior e mais eficaz na inativação das bactérias pesquisadas. Isso pode ser evidenciado através da eficiência de remoção dos microrganismos ( $\log$ ) ao $\log$ o dos CT estudados. A resistência do Clostridium perfringens foi visivelmente superior aos coliformes totais e a E. coli quando cloro ou ozônio foram aplicados. As maiores diferenças a respeito de sensibilidade ao desinfetante residiu para as bactérias coliformes 
totais e E. coli. Pois a bactéria formadora de esporo apresentou resistência aos dois agentes desinfetantes de maneira similar. Para o mesmo CT de 200mg.min/L o log de remoção não ultrapassou 1,2 unidades para ambos os desinfetantes.

Diferentemente para as outras bactérias analisadas, as suas sensibilidades foram distintas após a aplicação dos dois desinfetantes. Isso foi comprovado pelo log de remoção para mesmos CT. Enquanto as bactérias coliformes e E. coli apresentaram remoção de 2,2 e 2,5 log, respectivamente, após a aplicação do ozônio, o cloro provocou para estas mesmas bactérias a remoção de 4,5 log e 100\% de inativação para o mesmo CT.

\subsubsection{Desinfecção sequencial}

Foi observado aumento na eficiência na desinfecção quando os desinfetantes cloro e ozônio foram aplicados adicionalmente à radiação UV, quando comparado com a aplicação dos desinfetantes individualmente.

Em relação à sensibilidade das bactérias pesquisadas quando expostas ao cloro seguido de UV é observado que os coliformes totais são em média 3 vezes mais sensíveis que o Clostridium perfringens. Enquanto foi removido em média 2,6 log das bactérias formadoras de esporos, remove-se em média 5,9 log de coliformes totais.

A exposição à desinfecção sequencial de ozônio seguido de UV forneceu inativação inferior à observada para o cloro seguido de UV, lembrando que as dosagens aplicadas de ozônio foram, em média, a metade da aplicada pelo cloro e as dosagens de radiação UV usadas na ozonização também foram inferiores as usadas na cloração.

Desta maneira, surge a dúvida de qual seria o comportamento da inativação dos microrganismos indicadores se esses tivessem sido expostos às mesmas dosagens dos desinfetantes aplicados, ou seja, se tivessem sido aplicado as mesmas dosagens para cloro-UV e ozônio-UV. A comparação pode ser feita somente para a dose de $10 \mathrm{mg} / \mathrm{L}$, com a ressalva que a dose que se aproxima dessa para o ozônio foi de 11,4mg/L. A comparação destes dados de inativação permite verificar que o ozônio seguido de UV superou a inativação do Clostridium perfringens em relação à desinfecção com cloro em $0,35 \log$, o que não foi verificado para os coliformes totais, cuja sensibilidade foi maior ao cloro-UV.

Os resultados de inativação para a desinfecção sequencial ozônio-UV provaram que esta combinação foi, no geral, menos eficiente que para o cloro, mas as dosagens de cloro foram o dobro das que foram aplicadas para ozônio. Logo fica claro a capacidade desinfetante potencializada quando é utilizado desinfecção sequencial. Ademais foi provado que o ozônio, 
quando aplicado anteriormente ao UV promove uma melhora de qualidade no efluente que será lançado em corpos receptores. Essas melhorias são comprovadas na diminuição do lançamento de sólidos, em mudanças físico-químicas do efluente diminuído a DQO e da remoção de microrganismos.

\subsection{Limitações para a quantificação de coliformes totais e E. coli}

A metodologia de filtração em membranas apresenta limitações para amostras de esgoto. Como a amostra usada neste trabalho foi de efluente de estação de tratamento de esgoto, os sólidos suspensos totais interferiram na contagem das colônias de coliformes totais e de E. coli.

Estão ilustradas na Figura 5.38 colônias de coliformes totais e E. coli de uma amostra filtrada com alta quantidade de sólidos.

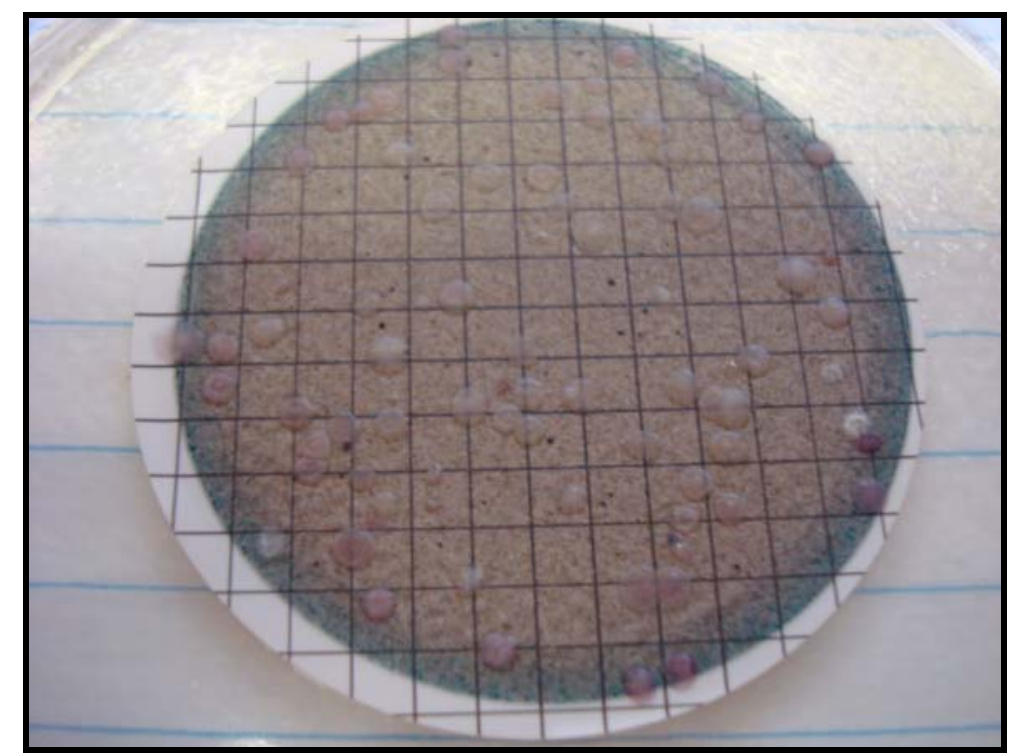

Figura 5.38: Membrana com colônias de coliformes totais envolvidas por sólidos

Portanto, sugere-se a utilização de outra metodologia para a determinação de coliformes totais e E. coli em amostras que contêm elevada concentração de sólidos suspensos. Para evitar a operação de filtração sugere-se adicionar a amostra no meio Chromocult ${ }^{\circledR}$ empregando os procedimentos "pour plate" ou "spread plate", nos quais não são necessários a filtração da amostra. 


\section{Conclusões}

- O C perfringens foi a bactéria mais resistente tanto à desinfecção convencional (apenas um desinfetante) quanto à desinfecção sequencial cloro seguido de UV e ozônio seguido de UV. A explicação pode estar no fato de que o Clostridium forma estruturas de resistência (esporo) que pode lhe conferir proteção;

* Ocorreu o seguinte padrão de resistência à desinfecção sequencial de cloro seguido de UV C. perfringens $>$ coliformes totais $>$ E. coli;

* Na ozonização seguida de UV, a resistência maior à desinfecção foi para $C$. perfringens, no entanto, houve ensaios em que E. coli apresentou-se mais resistente que coliformes totais;

Devido a alta resistência à desinfecção do Clostridium perfringens, quando comparado com os coliformes fecais, conclui-se que o uso dessa bactéria como indicador no exame de rotina no monitoramento de água residuária e águas superficiais podendo ser benéfico no sentido de proporcionar mais segurança para a saúde da população humana;

A ação do ozônio melhora a qualidade do efluente, quando comparado com o cloro, em se tratando de remoção de sólidos, diminuição da absorbância a 254 nm e de DQO;

$\mathrm{Na}$ desinfecção sequencial com cloro seguido de UV o tempo de contato de 10 minutos com o cloro forneceu eficiências superiores ou iguais quando comparado com os tempos de 20 e 30 minutos;

* O aumento das concentrações de cloro aplicadas ao longo dos tempos de contato, não significou em melhoria nas eficiências de inativação dos organismos indicadores;

* O cloro teve maior ação desinfetante que o ozônio para as concentrações e tempos de contato estudados. 


\section{Sugestões}

Realizar ensaios de desinfecção sequencial Cloro-radiação ultravioleta e Ozônioradiação ultravioleta aplicando-se as mesmas dosagens e intensidades de desinfetantes para comparar os resultados de resistência de microrganismos patogênicos;

* Realizar ensaios de desinfecção sequencial Cloro-radiação ultravioleta e Ozônioradiação ultravioleta aplicando-se dosagens e intensidades de desinfetantes menores que as utilizadas em métodos não sequenciais com vistas reduzir o consumo de desinfetantes, mantendo-se a eficiência desejada;

Avaliar a persistência dos microrganismos patogênicos no corpo receptor e utilizar as informações em análise de riscos à saúde da população que venha a usufruir de corpos d' água receptores à jusante de estações de tratamento de esgoto sanitário;

Realizar bioensaios ecotoxicológicos para verificar o efeito das concentrações de residuais dos desinfetantes cloro e o ozônio e de seus subprodutos na biota do corpo receptor e propor alternativas para diminuir os impactos gerados. 


\section{Bibliografia}

APHA. AMERICAN PUBLIC HEALTH ASSOCIATION. Standard Methods for the Examination of Water and Wastewater. 17th., American Public Health Association, Washington DC, (1989).

APHA. AMERICAN PUBLIC HEALTH ASSOCIATION. APHA; AWWA; WPCF. Standard Methods for Examination of Water and Wastewater. 19th., American Water Works Association, Water Environment Federation, Washington DC, USA, (1995).

APHA, AWWA; WPCF. AMERICAN PUBLIC HEALTH ASSOCIATION, AMERICAN WATER WORKS ASSOCIATION, WATER ENVIRONMENT FEDERATION Standard Methods for Examination of Water and Wastewater. 20th., Washington DC, USA, (1998).

AWWA, AMERICAN WATER WORKS ASSOCIATION RESEARCH FOUNDATION, Development and Validation of Rational Design Methods of Disinfection. Denver; AWWAR; (1995), 167 p.

BENENSON, A. S. Controle das doenças transmissíveis no homem. Relatório oficial da Associação Americana de Saúde Pública. 13ed, (1983). 420p.

BILOTTA, P. Estudo comparativo da ação do ozônio e radiação ultravioleta na desinfecção de esgoto sanitário. (2000). 130 p. Dissertação (mestrado)- Escola de Engenharia de São Carlos, Universidade de São Paulo. São Carlos, (2000).

BITTON, G. Wastewater Microbiology. Wiley-Liss, Inc. New York, Ny. (1994). 478p.

BLOOMFIELD, S. F. Resistance of bacterial spores to chemical agents. In: A. D. Russell, W. B. Hugo, and G. A. J. Ayliffe (ed.), Principles and practice of disinfection, preservation and sterilization, 3 ed., in press. Blackwell Science, Oxford, England. (1999).

BONATTI, J. R.; FRANCO, R. M. B. Investigação parasitológica conduzida em trabalhadores de uma ETE de Jundiaí-SP. Revista Panamericana de Infectologia, (2007). 9 (3): 17-19p.

CAMPOS, J. R.; PIZZIRANI, J. A. Desinfecção com radiação ultravioleta. $9^{\circ}$ Congresso Brasileiro de Engenharia Sanitária, Belo Horizonte, (1977). 19 p.

CETESB. Desinfecção de águas. BNH/ABES/CETESB, São Paulo, (1974). 210p. 
CHEREMISINOFF, P. N. Handbook of Water and Wastewater Treatment Technology. MARCEL DEKKER, INC. New York, (1995). Cap. 12, p. 449-480.

CHO, M.; KIM, J. H. ; YOON, J.Y. Investigating synergism during sequential inactivation of Bacillus subtilis spores with several disinfectants. Water Research. 40, (2006). p. 2911-2920.

COLETTI, F. J. Inativação de Microrganismos indicadores presentes em efluente secundário de Esgoto Sanitário com Radiação Ultravioleta. 239p. Tese (Doutorado) - Escola de Engenharia de São Carlos,Universidade de São Paulo, São Carlos, (2003).

COSTA, H. Estudo do Comportamento do Processo de ozonização como pós tratamento de efluentes de sistema de tratamento anaeróbio de águas residuárias domiciliares. 295 p. Tese (Doutorado)- Escola de Engenharia de São Carlos, Universidade de São Paulo, São Carlos, (2003).

DANIEL, L. A. Desinfecção de efluentes de esgoto sanitário pré-decantado empregando radiação ultravioleta. 124 p. Dissertação (Mestrado)- Escola de Engenharia de São Carlos, Universidade de São Paulo, São Carlos, (1989).

DANIEL, L. A. Desinfecção de esgotos com radiação ultravioleta: Fotoreativação e obtenção dos parâmetros cinéticos. 184 p. Tese (Doutorado)- Escola de Engenharia de São Carlos, Universidade de São Paulo, São Carlos, (1993).

DANIEL, L. A. (Coordenador.) Processos de desinfecção e desinfetantes alternativos na produção de água potável. São Carlos. ABES, Prosab 2 (2001). 139p.

DIAS, V. D. Radiação ultravioleta e ozônio aplicados como métodos alternativos de desinfecção de efluentes secundários de esgoto sanitário. 150 p. Dissertação (Mestrado)- Escola de Engenharia de São Carlos, Universidade de São Paulo, São Carlos, (2001).

FOEGEDING, P. M., \& BUSTA, F. F. Proposed mechanism for sensitization by hypochlorite treatment of Clostridium botulinum spores. Applied and Environmental Microbiolgy, (1983). n. 45: p. 1374-1379.

FOULK, C.W. Quantitative chemical analysis: an introduction to the science and practice of chemical measurement. 1 ed. New York : McGraw-Hill, (1952). 484 p.

FRITZ, J. Quantitative Analytical Chemistry. 5 ed. Englewood Cliffs, N.J.: Prentice Hall, (1987). $690 \mathrm{p}$.

GARCIA, L. S. Diagnostic Medical Parasitology. 4 ed. Washington D.C.: American Society for Microbiology. MAS Press. (2001). 1092p. 
GONÇALVES, F. R.; JORDÃO, E. P.; SOBRINHO, P. A. Introdução. In: Desinfeç̧ão de Efluentes Sanitários. PROSAB 3. Ricardo Franci Gonçalves (coordenador). (2003). p.1-17.

HAMELIN, C.; \& CHUNG, Y. S. Characterization of mucoid mutants of Escherichia coli K12 isolated after exposure to ozone. Journal of Bacteriology. (1975) April; 122(1): p. $19-24$.

HARAKEH, S. The behavior of viruses on disinfection by chlorine dioxide and other disinfectants in effluent. FEMS Microbiology Letters. 44, (1987). p.335-341.

HARM, W. Biological Effects of Ultraviolet Radiation. IUPAB. Biophysics Series. Cambridge, Eng.; New York : Cambridge University Press, (1980). 216 p.

HINRICHSEN, S. L. DIP: Doenças Infecciosas e Parasitárias. Rio de Janeiro: Guanabara Koogan S. A. (2005). 1098p.

JACOBSON, C. A. Encyclopedia of chemical reations. New York: Reinhold Pub. 8 v. (1958).

JOHNSON, J. D. Disinfection Water and Wastewater. By American Arbor Science Publishers, Inc. (1975). 425 p.

LANGLAIS, B. Ozone in water treatment: application and engineering. Lewis Publishers. (1991). 569 p.

LIMA, C. L S.; BRAZ, V. N. E RIVERA, G. I. Pesquisa de coliformes e estreptococos fecais em ambiente aquático protegido. Engenharia Sanitária e Ambiental, Rio de Janeiro, (1999). v. 4, n.3 e n. 4, ABES.

LOGE, F. J.; EMERICK, R. W.; THOMPSON, D. E; NELSON, D. C.; DARBY, J. L. Factors influencing ultraviolet disinfection performance part I: Light penetration to wastewater particles. Water Environment Research, (1999). v. 71, n. 3, p. 377-381, maio/junho.

MADIGAN, M. T. Microbiologia de BROCK. 10ed. São Paulo: Person Prentice Hall. (2004). 608p. + 1 CD-Rom.

McDONNELL, G; \& RUSSELL, A. D. Antiseptics and Disinfectants: Activity, Action, and Resistance. Clinical Microbiology Reviews. (1999). v.12, n.1, p. 147-179.

MEDENA, G. J; BAHAR, M \& SCHETS, F. M. Survival of Cryptosporidium Parvum, Escherichia coli, Faecal Enterococci and Clostridium perfringens in River Water: Influence of Temperature and Autochthonous microorganisms. Water Science Technology. (1997). v. 35, n. 11-12, p. 249-252. 
MONACO, B, P. Inativação de Indicadores Patogênicos em Sistemas Combinados de Tratamento e Pré-Desinfecção de Esgoto Sanitário. 136p. Tese (Doutorado). Escola de Engenharia de São Carlos, Universidade de São Paulo. São Carlos. (2006).

NT L5.213/1993 CETESB. Clostridium perfringens: determinação em amostras de água pela técnica de tubos múltiplos.

PASSIG, F. H. Reator anaeróbio híbrido para tratamento de esgoto sanitário. 151p. Tese (Doutorado). Escola de Engenharia de São Carlos, Universidade de São Paulo. São Carlos. (2005).

PELCZAR, M.; REID, R; CHAN, E. C. S. Microbiologia. São Paulo: Mcgraw-Hill. (1980). $566 \mathrm{p}$.

PELCZAR, M. J. JR; CHAN, E. C. S.; KRIEG N. R. Microbiologia Conceitos e Aplicações. 2v. Makron books. São Paulo. (1996).

PIVELI, R. P; \& KATO, M. T. Qualidade de águas e poluição: Aspectos Físico-Químicos. São Paulo: ABES. (2006). 285p.

ROBERTS, T. A. Microorganisms in Foods 5: Microbiological Specifications of Food Pathogens. International Commission on Microbiological Specifications for Foods, R. B. Tompkin, A. C. Baird-Parker - Publicado por Springer, (1996). 513 p.

RUSSELL, A. D. Bacterial spores and chemical sporicidal agents. Clinical Microbiology. (1990). v.3, n.2, p. 99-119.

RUSSELL, A. D. Bacterial resistance to disinfectants: present knowledge and future problems. Journal of Hospital Infection. (1999) 43. suppl: S p. 57-68.

SAGRIPANTI, J. L.; BONIFACIO, A. Comparative sporicidal effects of liquid chemical agents. Applied Environmental Microbiology. (1996). v.62, n. 2, p. 545-551.

SAMPAIO, A. de O. Desinfecção de esgotos sanitários com radiação ultravioleta. (1985). 96 p. Dissertação (Mestrado)- Escola de Engenharia de São Carlos, Universidade de São Paulo. São Carlos. (1985).

SARTORI, L; DANIEL, L. A. Adequation of The Microbiological Quality of Effluents from Secondary Lagoons for The Application of Ozone In Agriculture. In: 4 Th INTERNATIONAL SYMPOSIUM ON WASTEWATER RECLAMATION AND REUSE. AWWA. México. November, 12 - 14, 2003. México City.

SCHIRCH, F. T.; RODRIGUEZ, L. M. Desinfecção de esgotos para disposição o mar. In: Seminário Internacional - Desinfecção de águas de Abastecimento e Residuárias 
em países em Desenvolvimento, 1, Belo Horizonte, 1993. Anais. Minas Gerais, ABES, p. 313-322.

SHEIBLE, O. K. Development of a Rationally Based Protocol for the Ultraviolet Light Disinfection Process. Journal of Water Pollution Control Federation, (1987), v.59, n.1, 25-31, jan.

SOARES, L. V. Ozonização de Esgoto Sanitário: Estudo da Hidrodinâmica, Transferência de Massa e Inativação de Microrganismos Indicadores. 249p. Tese -(Doutorado) - Escola de Engenharia de São Carlos, Universidade de São Paulo, São Carlos, (2007).

SOUTO, G. D. B. Lixiviado de aterros sanitários brasileiros- estudo de remoção do nitrogênio amoniacal por processo de arraste com ar (“Stripping”). 371p. Tese (Doutorado)- Escola de Engenharia de São Carlos, Universidade de São Paulo, São Carlos, (2009).

SOUZA, J. B. Desinfecção de águas com cor e turbidez elevadas: Comparação técnica de processos alternativos ao cloro empregando radiação ultravioleta e ácido peracético. 130 p. Dissertação (Mestrado)- Escola de Engenharia de São Carlos, Universidade de São Paulo, São Carlos, (2000).

SOUZA, J. B. Avaliação de métodos para desinfecção de água empregando cloro, ácido peracético, ozônio e o processo de desinfecção combinado ozônio/cloro. 176p. Tese (Doutorado)- Escola de Engenharia de São Carlos, Universidade de São Paulo, São Carlos, (2006).

SPELLMAN, F. R. Choosing disinfection alternatives for water/wastewater treatment. Lancaster, Pa.: Technomic Pub. Co., (1999). 128 p.

TUNDISI, J. G. Água no Século XXI: Enfrentando a Escassez. RiMa Editora/ Instituto Internacional de Ecologia. (2003). 247 p

TYRRELL, S. A.; RIPPEY, S. R.; WATKINS, W. D. Inactivation of bacterial and viral indicators in secondary sewage effluents, using chlorine and ozone. Water Research, (1995). v.29, n. 11, p. 2483-2490.

USEPA, U.S. Environmental Protection Agency. Municipal Wastewater Disinfection Design Manual. EPA-625/1-86-021, Cincinnati, Ohio, 247.(1986).

USEPA, U.S. Alternative disinfectants and oxidants. Guidance Manual, EPA 815-R-99014. (1999).

VESCHETTI, E.; CUTILLI, D.; BOANADONNA, L.; BRIANCESCO, R.; MARTINI, C.; CECCHINI, G.; ANASTASI, P.; OHAVIANI, N. Pilot-plant comparative study of 
peracetic acid and sodium hypochlorite wastewater disinfection. (2003). Water Research, v.37, p. 78-94.

VOGEL, A. Análise inorgânica quantitativa: incluindo análise instrumental elementar. 4 ed. Rio de Janeiro: Editora Guanabara Dois. (1981). 690 p.

WANG, J.; WANG, L.; WANG, B.; ZHANG, J.; ZOU, Q. Impact of Suspended Particles and Enhancement Techniques on Ultraviolet Disinfection of a Secondary Effluent. Journal of Ocean University of China. October 30, (2006). v.5, n.4, p. 381-386.

WATER treatment handbook. 7 ed. France: Degrémont. 2 v. (2007). 1904p.

WEF. Water Environment Federation. Wastewater Disinfection: Manual of Practice. FD10 19-59. (1996).

WERF. Water Environment Research Foundation. DISINFECTION Comparison of UV Irradiation to Chlorination: Guidance for Achieving Optimal UV Performance. EUA. Project 91-WWD-1. (1995).

WHITE, G. C. Handbook of Chlorination: for Potable Water, Wastewater, Industrial Processes and Swimming Pools. Water Environment Research Foundation. New York : Van Nostrand Reinhold. (1972). 744 p.

WITT, V. M.; REIFF, F. M. Water disinfection Technologies for small communities and rural areas. In: Water Quality in Latin America: Balancing the Microbial and Chemical Risks in Drinking Water Disinfection, ILSI Argentina - Pan American Health Organization/ World Health Organization. Anais. Washington, D. C., ILSI PRESS, Edição de CRAUN, G. F., (1994), p. 139-168.

WU, J.; DOAN, H. Disinfection of Recycled red-meat- processing Wastewater by Ozone. Journal of Chemical Technology and Biotechnology. (2005) v.80, p. 828- 833.

XU, P; JANEX, M. L.; SAVOYE, P.; COCKX. A.; LAZAROVA, V. Wastewater disinfection by ozone: main parameters for process design. Water Research. (2002), v.36, p.1043-1055. 


\section{Apêndice A}

\subsection{Titulação Iodométrica}

\section{Assunto baseado na bibliografia VOGEL (1981)}

$\mathrm{O}$ tiossulfato de sódio $\left(\mathrm{Na}_{2} \mathrm{~S}_{2} \mathrm{O}_{3} \cdot 5 \mathrm{H}_{2} \mathrm{O}\right)$ é usado para determinar a quantidade de iodo formado na reação de ozônio com o iodeto de potássio presente no frasco lavador de gás da ozonização.

\section{Definições pertinentes à titulação iodométrica com tiossulfato de sódio}

Solução padrão é a solução que contém o peso do reagente conhecido com exatidão num volume definido de solução.

Por muitos anos, as concentrações foram expressas em termos de molaridade (i.e., número de moles de soluto por litro) e de normalidade (i.e., equivalentes de soluto por litro). Com a adoção do mol como unidade básica de quantidade pela União Internacional de Química pura e aplicada (IUPAC), tem-se a definição:

"O mol é a quantidade de substâncias que contém o mesmo número de unidades elementares que o número de átomos existentes em 0,012 quilograma de carbono-12. A unidade elementar deve ser especificada e pode ser um átomo, uma molécula, um ion, um radical, um elétron ou outra partícula ou grupo especificado de tais partículas".

Diante disso, o mol não é mais uma unidade de massa, mas sim uma unidade de quantidade de substâncias, e conseqüentemente, termos como mol-grama ficaram obsoletos.

Com a introdução desta definição vieram propostas de que termos como molaridade, peso equivalente e normalidade deveriam ser abandonados. No entanto, a experiência veio mostrar que existem certas vantagens práticas na conservação do uso dos termos equivalente e solução normal, de modo que as últimas recomendações da $\operatorname{IUPAC}^{15}$ sugerem as seguintes definições:

"O equivalente de uma substância é a quantidade dela que, numa dada reação, libera ou substitui a quantidade de hidrogênios que se combina com $3 g$ de carbono-12 no metano ${ }^{12} \mathrm{CH}_{4}$."

\footnotetext{
${ }^{15}$ International Union of Pura and applied chemistry (Aug, 1974). Information Bulletin. No. 36
} 
Nessa definição, a quantidade de hidrogênios referida pode ser substituída pela quantidade equivalente de eletricidade ou por um equivalente de qualquer outra substância, mas a reação que se aplica a reação deve ser devidamente especificada.

Uma solução normal é definida como aquela que contém um equivalente de uma dada espécie por litro de acordo com a reação especificada; e a solução molar é aquela que contém um mol de uma dada espécie por litro.

O 'equivalente' varia com o tipo de reação e acontece freqüentemente que o mesmo composto pode apresentar diferentes equivalentes em diferentes reações químicas. $\mathrm{O}$ que significa que para uma dada situação, uma solução pode ter uma concentração molar quando for empregada para uma finalidade, e uma normalidade, diferente desta, quando for usada numa outra reação química.

Tipos de reação:

* Neutralização:

Equivalente é um ácido;

Equivalente é uma base;

Formação de complexos e reação de precipitação;

* Reação de oxidação-redução.

Quando o equivalente é um ácido a sua massa contém $1,0078 \mathrm{~g}$ de hidrogênio substituível. O equivalente de um ácido monoprótico é igual ao mol, isto é, a normalidade é igual à molaridade; de um ácido diprótico o equivalente é $1 / 2 \mathrm{~mol}$ ou $1 / 3 \mathrm{~mol}$ quando o ácido é triprótico.

Equivalente de uma base é a massa que contém um grupo hidroxila substituível, i.e., $17,008 \mathrm{~g}$ de hidroxila ionizável; $17,008 \mathrm{~g}$ de hidroxila são equivalentes a $1,0078 \mathrm{~g}$ de hidrogênio. Portanto, na base formada pelo grupo 1A da Tabela periódica, o equivalente será igual ao mol e para o 2A o equivalente será a metade do mol.

No caso da Formação de complexos e reação de precipitação o equivalente é a massa de substâncias que contém ou reage com 1 mol de cátions univalente $\mathrm{M}^{+}$(que é equivalente a $1,0078 \mathrm{~g}$ de hidrogênio), $1 / 2 \mathrm{~mol}$ de um cátion bivalente $\mathrm{M}^{2+}, 1 / 3$ de um cátion $\mathrm{M}^{3+}$, etc.

Para o cátion, o equivalente é o mol dividido pela valência. Para um reagente que reage com esse cátion, o equivalente de um sal em uma reação de precipitação é o mol dividido pela valência total do íon reagente. 
Numa reação de formação de complexo, o equivalente é mais simplesmente deduzido escrevendo-se a equação iônica da reação. Por exemplo, o equivalente do cianeto de potássio na titulação com íon de potássio na titulação com íons de prata é 2 moles, por que a reação é:

$$
2 \mathrm{CN}^{-}+\mathrm{Ag}^{+} \leftrightarrow\left[\mathrm{Ag}\left(\mathrm{CN}_{2}\right)\right]^{-}
$$

\section{Reação de oxidação-redução.}

O equivalente de um agente oxidante ou redutor é definido como a massa de reagente que reage com ou que contém $1,008 \mathrm{~g}$ de $\mathrm{H}$ disponíveis ou $8 \mathrm{~g}$ de oxigênio disponível. Por 'disponível' entende-se a capacidade de ser utilizado na oxidação ou na redução.

O processo da oxidação-redução padrão é $\mathrm{H}=\mathrm{H}^{+}+1 \mathrm{e}^{-}$, onde e representa um elétron por átomo, ou número de avogrado de elétrons por mol. Se soubermos a mudança em número de avogrado de elétron por íon em qualquer reação de oxidação-redução, poderemos calcular o equivalente.

O equivalente para um agente oxidante é determinado pela mudança no número de oxidação que o elemento reduzido experimenta. Assim, por exemplo, para a redução do permanganato de potássio na presença de ácido sulfúrico diluído a Mn+2:

$\mathrm{KMnO}_{4} \rightarrow \mathrm{MnSO}_{4}$

Nessa equação, o equivalente é $1 / 5$ do mol, pois o Mn passou do estado de oxidação de +7 para +2 .

Isso ocorre de modo similar na redução do dicromato de potássio em solução ácida:

$\mathrm{K}_{2} \mathrm{Cr}_{2} \mathrm{O}_{7} \rightarrow \mathrm{Cr}_{2}\left(\mathrm{SO}_{4}\right)_{3}$ a mudança no número de oxidação de dois átomos de cromo é de +12 para +6 , ou seja, seis unidades de redução. Portanto, o equivalente do dicromato de potássio é 1/6 do mol. A fim de se encontrar o equivalente de um agente oxidante, dividimos o mol pela mudança no número de oxidação por molécula que se passa em algum elemento chave na substância.

$O$ equivalente para um agente redutor é determinado da mesma maneira pela mudança no número de oxidação pela qual o elemento oxidado passa.

Para exemplificar, apresenta-se a conversão do sulfato de ferro (II) em sulfato de ferro (III):

$$
2\left(\mathrm{FeSO}_{4}\right) \rightarrow \mathrm{Fe}_{2}\left(\mathrm{SO}_{4}\right)_{3}
$$

A mudança no número de oxidação do ferro vai de +2 para +3 , portanto, a mudança é de uma unidade de oxidação e o equivalente do sulfato de ferro (II) é $1 \mathrm{~mol}$.

Assim, de uma maneira geral se estabelece: 
- O equivalente de um elemento que participa de uma reação de oxidaçãoredução é a massa atômica dividida pela mudança no número de oxidação.

- Quando um átomo numa molécula complexa passa por uma mudança de número de oxidação, o equivalente da substância é o mol dividido pela mudança no número de oxidação do elemento oxidado ou reduzido. Se estiverem presentes mais de um átomo do elemento reativo, o mol é dividido pela mudança total no número de oxidação.

Quando um processo químico envolve uma sequência de reações, a reação que determina o equivalente é aquela em que a solução padrão é utilizada.

\section{Importância deste apêndice}

Todas essas definições são importantes para definir o real equivalente do tiossulfato de sódio na iodometria.

A explicação abaixo versa sobre o valor do equivalente do tiossulfato por Foulk, 1952.

"O iodo livre pode ser titulado com tiossulfato de sódio de acordo com a seguinte reação:

$$
2 \mathrm{Na}_{2} \mathrm{~S}_{2} \mathrm{O}_{3}+\mathrm{I}_{2} \rightarrow 2 \mathrm{NaI}+\mathrm{Na}_{2} \mathrm{~S}_{4} \mathrm{O}_{6} \quad \text { (WER)-(Jacobson, 1958) }
$$

A mudança no número de oxidação do enxofre do tiossulfato para tetrathionato é um bom exemplo do fato de que a contagem de cargas de cada elemento como descrito na reação acima não fornece a distribuição verdadeira de elétrons na molécula. De acordo com a regra do cálculo do número de oxidação, o número de oxidação aumenta de +2 no tiossulfato para uma média de 2,5 no tetrationato. Desde que 2 átomos de enxofre possuam essa carga, a mudança líquida por molécula de tiossulfato é uma unidade. A perda de 1/2 elétron por átomo de enxofre é obviamente inconsistente com a teoria aceita da indivisibilidade dos elétrons. Porém, é mais conveniente calcular o número de oxidação médio de um elemento em um composto, mesmo que o resultado seja fracional, que assumir diferente número de oxidação para cada átomo em um mesmo elemento e um composto. Mesmo que o número de oxidação fracional seja assumido, a mudança total por molécula em uma reação de oxidação-redução é sempre um número inteiro. Da equação WER parece que cada átomo de enxofre perde $1 / 2$ elétron. Essa curiosa situação acontece devido ao fato que ambos os elétrons de enxofre não possuem a mesma quantidade de carga. O 1/2 elétron representa a carga média em cada um dos átomos de enxofre. 
O equivalente grama do tiossulfato é o mesmo que o seu peso molecular. Se os elétrons que foram ganhos e perdidos na equação puderem ser observados, será inferido que cada mol de tiossulfato perde 1 elétron e cada átomo de iodo ganha 1 elétron."

\section{Preparação de solução de tiossulfato 0,025N}

O equivalente do tiossulfato é o mol, 248,18. Para se preparar uma solução de $0,025 \mathrm{~N}$ dissolve-se cerca de 6,2 g de tiossulfato de sódio cristalizado em um litro de água, em um balão volumétrico.

Essa solução pode ser padronizada por vários métodos, podendo ser usado iodato de potássio, dicromato de potássio, solução padrão de iodo e sulfato de cério (IV).

É importante salientar a estabilidade das soluções de tiossulfato, pois soluções preparadas com água destilada podem conter um excesso de dióxido de carbono, podendo ocasionar a decomposição do enxofre:

$$
\mathrm{S}_{2} \mathrm{O}_{3}^{-2}+\mathrm{H}^{+} \leftrightarrow \mathrm{HSO}^{3-}+\mathrm{S}
$$

A decomposição do tiossulfato pode ocorrer por ação bacteriana (Thiobacillus thioparus), particularmente se a solução for guardada por muito tempo e para se evitar esses inconvenientes, recomenda-se os seguintes cuidados:

1 - Preparar a solução com água destilada fervida previamente;

2 - Adicionar três gotas de clorofórmio ou $10 \mathrm{ml}$ de iodeto de mercúrio (II) por litro (para melhorar a armazenagem da solução);

3 - Evitar a exposição à luz, pois ela tende a acelerar a decomposição da solução.

\section{Padronização da solução de tiossulfato de sódio}

O tiossulfato não é um padrão primário, pois existe uma incerteza sobre o seu conteúdo exato de água. Assim torna-se necessário realizar a padronização dessa solução. A padronizaão com o iodato de potássio é realizada através das seguinte equações:

$\mathrm{IO}_{3}^{-}+5 \mathrm{I}^{-}+6 \mathrm{H}^{+}=3 \mathrm{I}_{2}+3 \mathrm{H}_{2} \mathrm{O}$

$2 \mathrm{~S}_{2} \mathrm{O}_{3}{ }^{-}+\mathrm{I}_{2}=\mathrm{S}_{4} \mathrm{O}_{6}+2 \mathrm{I}^{-}$

O iodato reage com o iodeto de potássio liberando iodo. Portanto, é necessário pesar, com exatidão $0,14-0,15 \mathrm{~g}$ de iodato de potássio puro e seco, dissolver em $25 \mathrm{ml}$ de água destilada fervida e fria, adicionar $2 \mathrm{~g}$ de iodeto de potássio e $5 \mathrm{ml}$ de ácido sulfúrico $1 \mathrm{M}$. Titular, com agitação constante, o iodo liberado com a solução de tiossulfato. Quando a cor 
estiver pálida, adicionar solução de amido e continuar a titulação até que a cor mude de azul para incolor. Titular em triplicada.

Se o amido é adicionado quando a cor amarela ainda estiver muito intensa, um complexo precipitado pode ocorrer na forma de grânulos escuros. Uma vez formada, essas partículas escuras se dissolvem lentamente e podem confundir a verdadeira determinação do ponto final da titulação. Esses grânulos escuros indesejados são evitados adicionando-se o amido quando a cor da solução na titulação estiver amarelo-palha (Foulk, 1952).

Com a padronização da solução de tiossulfato, pode-se saber com exatidão o valor da sua normalidade. Essa solução padronizada pode ser então usada para titular soluções com diversas concentrações de iodo formado com a reação do iodeto de potássio e o ozônio. $\mathbf{O}$ iodato é o correspondente ao ozônio.

Com o valor do volume usado de tiossulfato de sódio nessa titulação, poder-se-á saber a produção de ozônio produzido após a ozonização capturada no frasco lavador de gás. 